This report was prepared as an account of Government sponsored work. Neither the United States, nor the Commission, nor any person acting on behalf of the Commission:

A. Makes any warranty or representation, express or implied, with respect to the accuracy, completeness, or usefulness of the information contained in this report, or that the use of any information, apparatus, method, or process disclosed in this report may not infringe privately owned rights; or

B. Assumes any liabilities with respect to the use of, or for damages resulting from the use of any information, apparatus, method, or process disclosed in this report.

As used in the above, "person acting on behalf of the Commission" includes any employee or contractor of the Commission to the extent that such employee or contractor prepares, handles or distributes, or provides access to, any information pursuant to his employment or contract with the Commission.

ARGONNE NATIONAL LABORATORY

P. O. Box 299

Lemont, Illinois

\title{
REFINING OF URANIUM BY MELTING AND LIQUATION
}

by

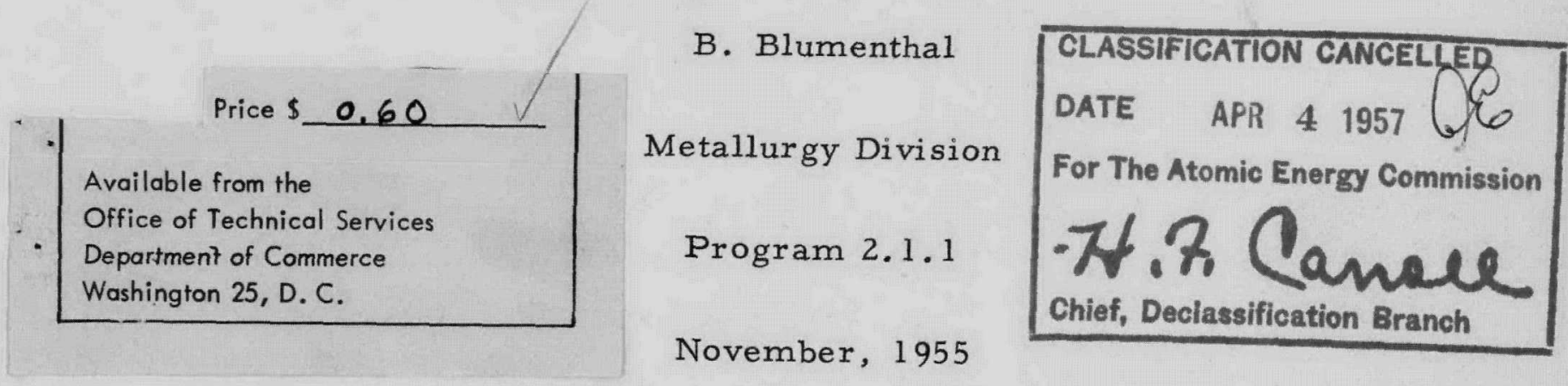

Part of the material in this report has been presented in the following Quarterly Reports:

ANL-4243 (pp. 34-37)

ANL-4316 (pp. 56-70)

ANL-4341 (pp. 14-18)

ANL-4399 (pp. 27-32)

ANL-4507 (pp. 59-76)

ANL-4655 (pp. 35, 40-47)

ANL-5097 (pp. 53-58)
December 31,1948

March 31, 1949

June 30,1949

December 31, 1949

March 31, 1950

March 31, 1951

June 30,1953

Operated by The University of Chicago

under

Contract W-31-109-eng-38 


\section{DISCLAIMER}

This report was prepared as an account of work sponsored by an agency of the United States Government. Neither the United States Government nor any agency Thereof, nor any of their employees, makes any warranty, express or implied, or assumes any legal liability or responsibility for the accuracy, completeness, or usefulness of any information, apparatus, product, or process disclosed, or represents that its use would not infringe privately owned rights. Reference herein to any specific commercial product, process, or service by trade name, trademark, manufacturer, or otherwise does not necessarily constitute or imply its endorsement, recommendation, or favoring by the United States Government or any agency thereof. The views and opinions of authors expressed herein do not necessarily state or reflect those of the United States Government or any agency thereof. 


\section{DISCLAIMER}

Portions of this document may be illegible in electronic image products. Images are produced from the best available original document. 
TABLE OF CONTENTS

Page

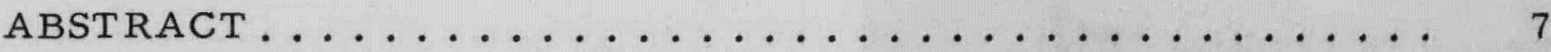

I. INTRODUCTION $\ldots \ldots \ldots \ldots \ldots \ldots \ldots \ldots \ldots \ldots \ldots \ldots \ldots \ldots$

II. EXPERIMENT AL METHODS ................ 11

A. Melting and Vacuum Equipment. .............. 11

1. The Resistance Furnace ................. 11

2. The Induction Furnace ................ 13

B. Crucibles ........................ 14

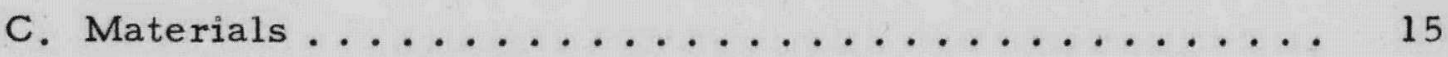

D. Sampling and Analytical Methods............ 15

E. Metallographic Technique ............... 15

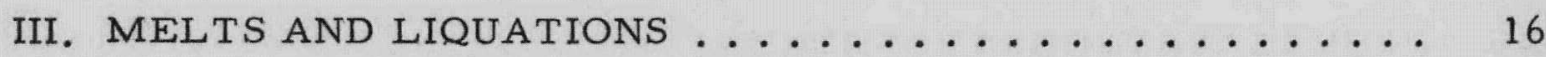

A. Liquations in Resistance Furnace ............. 16

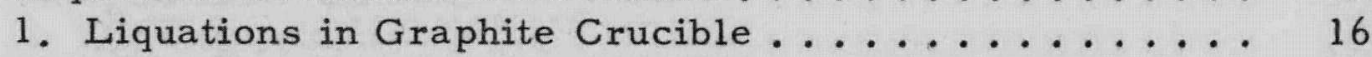

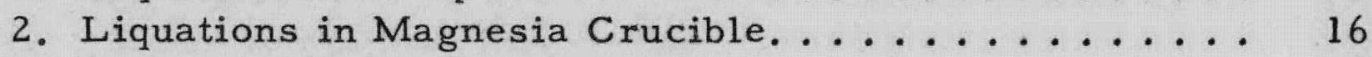

3. Liquations in Urania Crucible .............. 16

B. Melts in Induction Furnace................ 18

1. Melts in Magnesia and Urania Crucibles ......... 18

2. Melts in Helium and Hydrogen Atmosphere........ 18

3. Melts in Various Crucible Materials ............ 19

C. Melts and Liquations with Nitrogen Additions ....... 19

1. Melt in Nitrogen Atmosphere............... 19

2. Induction Melts with Uranium Nitride in Magnesia Crucible................. 20

3. Induction Melts with Uranium Nitride in Urania Crucible.................... 20

4. Liquations of Sepa rately Nitrided Uranium . . . . . . . 21

5. One-Step Nitriding and Liquation Melts ......... 21

6. One-Step Nitriding and Liquation Melts with Calcium Additions .................. 21

D. Melts with Alloying Additions............... 21

1. Melts with Tantalum, Titanium and Zirconium ..... 21

2. Melts Stirred with Tantalum Rod ............ 22 
Page

IV. METALLOGRAPHY .................... 23

A. Metallography of Project Grade Uranium .......... 23

1. Phases in Uranium. ................... 23

2. Microstructure of Biscuit Metal and Remelted Biscuit Metal .................... 24

3. Microstructure of Hanford Slugs and Remelted Hanford Slugs .................... 24

B. Effect of Liquation on Microstructure ........... 25

1. Liquation in Graphite Crucible............ 25

2. Liquation in Magnesia Crucible ............ 25

3. Liquation in Urania Crucible ............ 25

C. Effect of Induction Melting on Microstructure ....... 26

1. Melting in Magnesia and Urania Crucibles ....... 26

2. Melting in Helium and Hydrogen Atmosphere ...... 27

3. Melting in Various Crucible Materials.......... 27

D. Effect of Melting and Liquating with Nitrides on

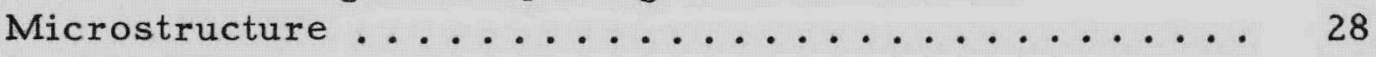

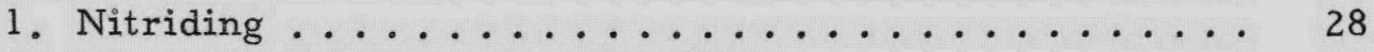

2. Liquation Subsequent to Nitriding ........... 28

3. One Step Nitriding and Liquation............ 29

4. One Step Nitriding and Liquation with Calcium

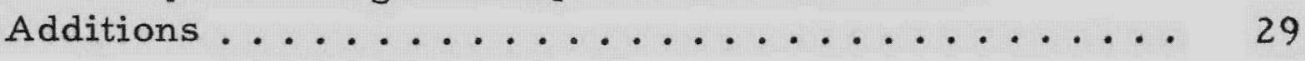

E. Effect of Alloying Additions on Microstructure . . . . . 29

1. Tantalum Additions .................. 29

2. Melts Stirred with Tantalum Rod ........... 30

3. Titanium and Zirconium Additions .......... 30

V. DISCUSSION AND CONCLUSIONS ............... 31

A. Carbon Removal..................... 31

B. Oxygen Removal .................... 32

C. Nitrogen Removal. .................. 32

D. Removal of Salt and Metallic Impurities.......... 33

E. Composition and Structure..................... 33

F. Optimum Melting Conditions for Uranium . . . . . . . . 34 
TABLE OF CONTENTS

Page

VI. APPENDIX: THE CONTROL OF STRINGERS IN REACTOR

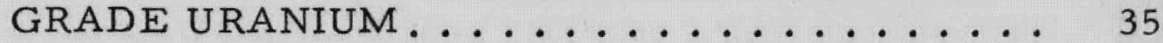

VII. APPENDIX: IDENTIFICATION OF LIQUATION LAYER INCLUSIONS BY X-RAY DIFFRACTION

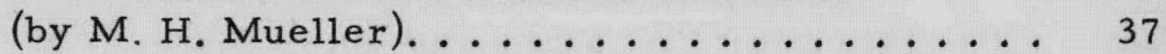

ACKNOWLEDGMENTS . . . . . . . . . . . . . . 39

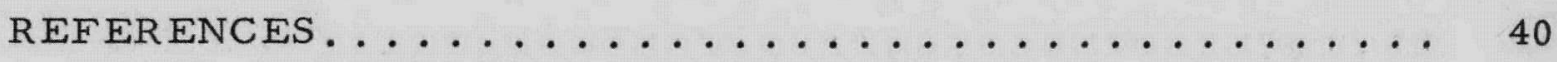




\title{
REFINING OF URANIUM BY MELTING AND LIQUATION
}

by

\author{
B. Blumenthal
}

\section{ABSTRACT}

Reactor grade uranium, both biscuit metal and Hanford fuel slugs was melted and liquated in a high vacuum in a variety of crucible materials. Resistance and induction heating were used. Liquation in urania crucibles removes nitrogen and oxygen to very low limits (less than $10 \mathrm{ppm}$ ). Carbon is partially removed by this method. A variety of conditions and reactions was studied to effect a more complete carbon removal. The study comprised the use of magnesium oxide crucibles, melting in a hydrogen atmosphere, uranium nitride, tantalum, titanium and zirconium additions, and stirring with a tantalum rod. These experiments had but a limited success with respect to carbon removal. Most of the reactions greatly affected the microstructure of uranium and, therefore, were evaluated metallographically as well as by chemical and spectrochemical analysis. The optimum melting conditions are stated by which the contamination of reactor grade uranium can be held within 130 to $200 \mathrm{ppm}$ total impurities. An appendix describes a new process for the control of stringers in reactor grade uranium. 


\section{INTRODUCTION}

The present work was started with the intention of developing a method for removing carbon from reactor grade uranium. Since carbon is one of the major impurities in reactor grade uranium, its removal was expected to cause a substantial improvement of the metal quality and to provide a suitable base material for many research purposes. The effort to reduce the carbon content of uranium did not produce a metallographically clean metal. This was achieved by the production of electrolytic uranium(1) and the melting of the electrolytic crystals into ingots. (2) It did, however, give much information regarding the changes in composition on melting under a great variety of conditions and regarding the significant reactions in molten uranium.

The data by Dahl and Cleaves(3) obtained in determining the freezing point of uranium showed that it should be possible to reduce the carbon content of uranium to very low concentrations by liquation (6 ppm). Liquation is a metallurgical refining process in which the metal to be refined is kept molten for some time at a temperature near its freezing point, whereby the impurity, usually in form of a solid, light, and insoluble intermediate compound, may migrate to the top surface from where it is removed either before or after solidification. The data by Snow(4) indicated a low solubility of carbon in liquid uranium near its freezing point. The density of uranium at the melting point may be estimated to be $17.7 \mathrm{~g} / \mathrm{cc}$ and that of UC less than $13.6 \mathrm{~g} / \mathrm{cc}$. Therefore, the conditions for the removal of carbon from uranium appeared to be favorable. Nevertheless, a series of liquation experiments did not result in metal of low carbon content and subsequently many experiments were carried out in an effort to find the cause of the discrepancy.

Since Dahl and Cleaves worked in a helium atmosphere, it was first thought that residual hydrogen or nitrogen could have caused the carbon removal. Since about $30 \mathrm{ppm}$ by weight of hydrogen are soluble in molten uranium at about $1225^{\circ} \mathrm{C}$, its solubility at 25 microns is $0.17 \mathrm{ppm}$ by weight or 40 atoms per million according to Sievert's Law. This solubility certainly is small, yet was felt to be high enough to test the reversibility of the reaction

$$
\mathrm{U}+\mathrm{CH}_{4}=\mathrm{UC}+2 \mathrm{H}_{2}
$$

This reaction was used by Litz, Garret, and Croxton(5) to prepare UC from metallic uranium in the temperature range of $625^{\circ}$ to $900^{\circ} \mathrm{C}$. It should proceed in the opposite direction if $\mathrm{CH}_{4}$ is continually removed from a melt in a hydrogen atmosphere. The experiments indicated that such a reversal does not happen. 
The first liquation experiments showed that nitrogen is readily removed from uranium by liquation. A layer of UN was collected at the top of a melt under conditions of great latitude with respect to time, temperature and pressure. Since this layer contained much carbide and since the monocarbide and the nitride fulfill the conditions of mutual solubility $(6)$ (both have a $\mathrm{NaCl}$ type lattice and their lattice parameters of $\mathrm{a}_{0}(\mathrm{UC})=4.95 \mathrm{kX}$ and $a_{0}(U N)=4.88 \mathrm{kX}$ differ by no more than $1.4 \%$ ) and might form a continuous series of solid solutions, it was thought that a nitride-carbide solid solution would more easily liquate than the carbide alone. Extensive experiments were carried out to add sufficient nitrogen to the melt so that either on melting in the presence of nitride or on liquation subsequent to a separate nitriding step, the nitride would act as a carrier and remove the monocarbide from the melt. These experiments had a limited success.

Since none of these reactions occurred without participation of the crucible materials, the investigation was extended to include the effect of various crucible materials. While most of these experiments resulted in additional contamination, a substantial improvement was noted in two cases. Liquations in a urania crucible effectively permitted the removal of oxygen from the metal, and melts in a magnesia crucible vigorously stirred by induction substantially reduced the carbon content of the metal apparently by oxidation. The reactions

or

$$
\begin{aligned}
& 2 \mathrm{MgO}+\mathrm{UC} \longrightarrow \mathrm{CO}+\mathrm{UO}+2 \mathrm{Mg} \\
& 3 \mathrm{MgO}+\mathrm{UC} \longrightarrow \mathrm{CO}+\mathrm{UO}_{2}+3 \mathrm{Mg}
\end{aligned}
$$

proceed in a high vacuum. The vapor pressure of magnesium under the temperature and pressure conditions concerned is high enough to cause its volatilization and redeposition on the cold surfaces of the furnace and vacuum system. The rate of reaction between the uranium metal and the carbon monoxide according to:

or

$$
\mathrm{CO}+2 \mathrm{U} \longrightarrow \mathrm{UO}+\mathrm{UC}
$$

$$
2 \mathrm{CO}+3 \mathrm{U} \longrightarrow \mathrm{UO}_{2}+2 \mathrm{UC}
$$

apparently is slow enough so that it will not interfere with the removal of the carbon monoxide from the melt.

The use of tantalum as a means of removing carbon from uranium was first suggested by Schramm, Gordon, and Kaufmann(7) who found a reduction of the carbon content of uranium after having stirred a melt with a tantalum rod. They found that a layer having a composition corresponding to the formula $\mathrm{UTa}_{10} \mathrm{C}_{4}$ was formed on the rod surface. The stirring rod was withdrawn before the metal was allowed to solidify. The carbon content was reduced to less than $20 \mathrm{ppm}$. The metal, however, was contaminated with tantalum. This was of no concern to the authors who intended to alloy the metal with tantalum. Similar stirring experiments, in addition to 
liquations in which tantalum, titanium, and zirconium were added to uranium, were carried out in the course of this research and lowered the carbon content of uranium to some extent. Contamination, however, with the addition agents was high and discouraged continuation of this approach.

Whereas none of these experiments produced a method of complete carbon removal, they did result in processes for partial removal of carbon and almost total removal of oxygen and nitrogen. They also gave information on the behavior of different crucible materials and the changes that occur in reactor grade material on melting. They permitted the definition of the optimum melting conditions of reactor grade material for minimum contamination.

The experiments were carried out in two vacuum furnace systems. The development of these two systems paralleled the investigation of the metallurgical processes. One system consisted, in its most recent form, of a Globar resistance furnace equipped with an apparatus for directional solidification. The vacuum system of high pumping speed contained a chevron-type cold trap which effectively prevented back diffusion of oil into the furnace chamber and contamination of a melt with carbon. The other system was an induction furnace. Its power was supplied by a $6 \mathrm{kw}$ Ajax oscillator. This oscillator permitted the melting of uranium without an intermediate heater-susceptor, and, therefore, vigorous stirring. This furnace was connected to a vacuum system of somewhat smaller pumping speed and had a pot-type cold trap which was not quite as effective as the chevron-type cold trap in trapping residual oil vapors. This furnace was designed to work either under vacuum or under a slightly positive inert gas pressure. The two furnace systems were built and developed as the metallurgical work progressed, and much experimental melting was done at intermediate stages of the development. The experimental data will be presented in a manner in which emphasis is placed on the conditions under which each series of experiments was made, particularly with respect to furnace type and crucible material. The metallurgical reactions which can be deduced from these data will then be discussed in a separate chapter. 


\section{EXPERIMENTAL METHODS}

A. Melting and Vacuum Equipment

1. The Resistance Furnace:

The resistance furnace was developed in three stages, each one using the same 3-kw Globar resistance furnace (Burrell Model CTC 1-13 equipped with a tap transformer) placed in a vertical position. The first stage (Drawing 1, p. 59) was characterized by a vacuum system of low pumping speed, consisting of a nonfractionating 2" oil diffusion pump (Model $\mathrm{H}-2$ by National Research Corporation), a laboratory type Pyrex glass cold trap cooled by liquid nitrogen, and backed up by a mechanical forepump of a pumping speed of $2.5 \mathrm{l} / \mathrm{sec}$ at 1 micron (Welch No. 1397). These parts were connected by a flexible hose to the furnace chamber consisting of a McDanel porcelain tube, 2-3/4" I.D., closed at its bottom. A sight glass on top of the connecting $\mathrm{T}$ permitted observation of the melt and temperature measurement by a Leeds and Northrup optical pyrometer. The furnace temperature was controlled by a platinum $/ 10 \%$ platinum-rhodium thermocouple touching the outside center of the furnace tube. This thermocouple was used in a conventional control circuit with a Wheelco Capacitrol. The seal between the porcelain tube and the furnace head is shown in Drawing $2, p .60$. The end of the porcelain tube (1) was ground flat within \pm 0.0005 " and carried a Neoprene gasket (2). A ring with spiral grooves (3) was cemented to the tube slightly below the end of the tube by means of No.1 Sauereisen cement (4). This ring was water cooled by copper tubing soft soldered into its grooves. A second ring (5) fitted loösely over ring (3). The opposing water cooled flange (6) extended into the furnace tube to prevent the Neoprene gasket from being pulled into the furnace and to shield it from direct radiation. The assembly was held together under slight pressure by four Cclamps (7). To insure a good seal, good perpendicular alignment of the Cclamps was necessary. This type of seal was satisfactory for vacua of $2 \cdot 10^{-7} \mathrm{~mm}$ mercury.

The vacuum system produced operating pressures of 10 to 20 microns, good enough for the melting of solid pieces of uranium. Such a vacuum, however, was unsatisfactory for melting turnings or electrolytic crystals or smaller solid pieces because oxide films formed on each individual piece or particle and interfered with their fusion. Vigorous inductive stirring would have broken down these barriers; but even long periods of holding at a high temperature did not do it in a resistance furnace where thermal convection currents were the only means of stirring.

At the second stage of development the inadequate first vaccum system was replaced by one of high pumping speed (Drawing 3, p. 61, and Photograph 1, p. 68). Simultaneously, a system of directional solidification

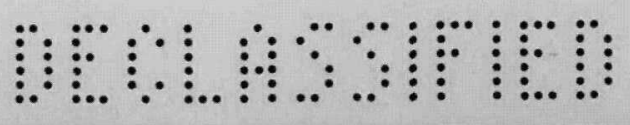


was installed. The latter has previously been described in ANL-5019(2) (Drawing 5, p. 63 and Photographs 2 and 3, pp. 69, 70). The vacuum system consisted of a 6" fractionating oil diffusion pump (MCF 700 by Consolidated Vacuum Corporation), a 3-7/8"oil diffusion booster pump (MB 100 by the same concern), and a mechanical forepump of $3.8 \mathrm{l} / \mathrm{sec}$ pumping speed at 1 micron pressure (CVD 556 by Kinney Manufacturing Company). This vacuum system gave pressures in the lower $10^{-6} \mathrm{~mm}$ mercury range. The MB 100 booster pump was later replaced by a 6" MB 200 booster pump, allowing reduction of the pump-down time. A water-cooled baffle at the intake of the MCF 700 pump completed the system. The connecting head between the pumps and the furnace was made of naval brass low in lead. All flange connections were made with O-ring seals following rigorously the manufacturer's instructions for making the $\mathrm{O}-$ ring grooves. No radial scratches or tool marks were allowed on the sealing surfaces.

The most recent design of the water-cooled baffle is shown in Drawing $4, p .62$. Its brass angles were arranged in such a manner that no molecule could pass without hitting a surface. The entrance of the cooling water in copper tubes through the side walls made it easy to keep the baffle leak-tight. Its small height was advantageous from the standpoint of both space requirement and reduced losses of pumping speed.

While working with high purity electrolytic uranium it was found that considerable contamination of uranium with carbon took place even in this system of high pumping speed. The contamination was traced to residual. oil vapors and it became mandatory to add to the system a cold trap that would effectively remove the residual oil vapors before they could reach the furnace tube and the melt. A new stainless steel connecting head was built providing for the insertion of either a pot-type or chevron-type cold trap or both. The new arrangement is shown in Drawing 6, p. 64. The chevron-type cold trap (Drawing 7, p. 65) was previously described in ANL-5019.(2) This system made it possible to melt high purity electrolytic uranium crystals without serious contamination. On pumping down cold, a pressure of $2 \cdot 10^{-7} \mathrm{~mm}$ mercury could be attained within 3 hours and uranium could be kept molten for long periods of time at a pressure of $5 \cdot 10^{-7}$ to $1 \cdot 10^{-6} \mathrm{~mm}$ mercury. Pressures were measured both by ionization gages and cold cathode ionization gages and at the intermediate stages by thermocouple gages at the places indicated in the schematic drawings.

The temperature was controlled and measured by a platinum/10\% platinum-rhodium thermocouple touching the outside center of the furnace. The temperature difference between the melt and the temperature indicated by this thermocouple was measured by replacing the apparatus of directional solidification by a sight glass and optically measuring the temperature of a stationary melt. The temperature difference was repeatedly found to be -10 to $-12^{\circ} \mathrm{C}$ and this correction was applied to the temperature measured by the 
outside couple. In making optical temperature measurements of uranium, it must be considered that the emissivity of pure uranium is much lower than that of a black body. This applies to the solid as well as the liquid state. No experimental data a re available for the liquid state. Deviation from black body radiation is considerably smaller for uranium dioxide bodies and slags; in sighting at a melt with an optical pyrometer one should look at the slag floating on a uranium melt rather than at the melt itself.

\section{The Induction Furnace}

The induction furnace was developed in two stages. A 6-kw Ajax-Northrup converter was used as a power source. The band of low frequencies characteristic of these units permitted melting of uranium without a heater susceptor. The melts thus were always vigorously stirred by induction. However, temperature control was poor. A maximum temperature of $1750^{\circ} \mathrm{C}$ was attainable. The optical temperature measurement was frequently made difficult, if not impossible, by the clouding of the observation window by material volatilized from the melt. Therefore, all temperature data of the induction melts are approximations based on measurements at the time when the sight glass was relatively clear, and a correction for loss of transmissivity determined by calibration of the sight glass against a standard lamp after the melt had been completed.

The first furnace consisted of a quartz tube of 2 " diameter, its ends ground flat, placed in a vertical position on a support provided with a gas inlet (Drawing 8, p. 66). The head carried the gas outlet and the vacuum connection. Flat neoprene gaskets provided the seals between the support, the furnace tube, and the head. Three spring-loaded rods pressed the head on the tube and the tube on the support. The springs at the ends of the rods allowed for expansion of the hot quartz tube. The unit could be used for both melting in a vacuo and in an atmosphere. A suitable arrangement of valves allowed for alternate use of either one of the two media. This furnace was first run with a mechanical forepump alone giving vacua of 25 to $50 \mathrm{mi}$ crons. An MB 100 booster pump was later inserted and vacua of 5 to 25 microns were readily maintained.

This preliminary setup was replaced by a larger system capable of producing a vacuum of $2 \cdot 10^{-7} \mathrm{~mm}$ mercury. This system was designed to give versatile service and provide for alternate use of a high vacuum and an inert atmosphere at slight positive pressure. The central part of the system (Drawing 9, p. 67, and Photograph 4, p. 71) was a rectangular box welded from stainless steel; the vacuum system was suspended from one end and a furnace tube or other equipment could be attached at the other end. The vacuum system consisted of a MCF 700 oil diffusion pump, a MB 100 booster pump

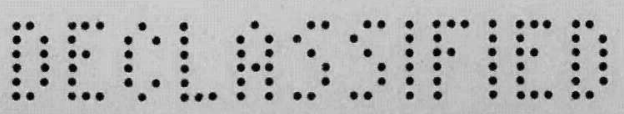




\section{4}

(both by Consolidated Vacuum Corporation), and a No. 1397 Welch mechanical forepump. A 6" baffle and valve combination separated the vacuum system from the central box. The box carried a pot-type cold trap during the experiments reported in this paper. The vacuum gages also were mounted on the box. The furnace tube was a 2-3/4" Vycor tube placed on a flat neoprene gasket in an interchangeable flange of the central box. The crucible was supported by a refractory tube standing on the bottom flange of the box. Several heads were used. The simplest one just carried a sight glass. Other heads were made to carry vacuum gages or a seal to insert a stirring rod into the system. For inert atmosphere work the head was pressed onto the Vycor tube and its support by the three spring-loaded brass rods mentioned above. Provisions were also made to permit use of bottom pour crucibles with stopper rods and the insertion of a water-cooled copper mold. The vacuum system proved to be quite versatile and was later used in conjunction with other oscillators on a variety of research projects.

The two furnace systems, the resistance furnace and the induction furnace, produced operating vacua of $10^{-6} \mathrm{~mm}$ mercury or better. Because of its larger forepump and booster pump capacity the resistance unit had a higher pumping speed and provided a shorter pump down time than the induction unit. Both furnaces were used for their inherent characteristics. The resistance furnace was used for liquation and separation experiments at moderate temperatures $\left(1100^{\circ}\right.$ to $\left.1350^{\circ} \mathrm{C}\right)$. The system of directional solidification produced sound ingots of high density without sink holes and shrinkage cavities. The induction furnace, although very poor in maintaining a constant temperature, gave good mixing of the reactants, interaction between the melt and the crucible, high temperatures (up to $1750^{\circ} \mathrm{C}$ ), but ingots with many shrinkage cavities and sink holes. By using both furnaces consecutively the advantages of both furnaces were combined in two of the experimental series.

\section{B. Crucibles}

The graphite crucibles were machined from electrode graphite. The magnesia crucibles were high purity magnesia crucibles from Norton Manufacturing Company with a maximum silicon content of $2 \%$, except the one that was used on Melt B24 (Table III, p. 44) which was made by the Ceramics Group of this laboratory. The lime crucible was an occasional experimental product by Norton, and the zirconia crucible was made from stabilized zirconia by the same concern. The titanium carbide crucible was made by KAPL and obtained through the courtesy of Dr. A. Seybolt. The urania crucibles were produced by the Ceramics Group of this laboratory. $(8,9)$ The tantalum crucible was a deep drawn cylindrical cup of $0.015^{\prime \prime}$ wall and was obtained from Fansteel Metallurgical Corporation. 
C. Materials

The experiments were made/with/both biscuit metal/and[Fanford] slugs For slug rejects, which are biscuit metal vacuum melted in graphite crucibles and cast into graphite molds. The slugs were received as rolled. [The slug rejects differed from regular slugs not by composition but by mechanieal defects, faults, etc., which had no effect on the present work] Typical analyses of these materials a re listed in Table I, p. 42. A distinct difference in composition exists between the composition of biscuits made in 1948 and 1949 and those received in 1953. The later biscuits were lower in carbon and occasionally somewhat higher in nickel than the earlier ones. Some of the analytical data for biscuit metal cannot be taken as representing the average composition of the metal since both nitrogen and magnesium, and probably also oxygen, were not uniformly distributed and probably varied by as much as a factor of five. On the other hand, the analysis of a full cross section of a slug without its surface layers usually is representative of a composition of the metal if its carbon and nitrogen contents are not unusually high. Here, too, segregation phenomena may be a factor.

D. Sampling and Analytical Methods

The methods of sampling and of chemical and spectrochemical analysis were identical with those used on high purity electrolytic uranium and have previously been described in ANL-5019.(2) Only a few samples were analyzed for oxygen since the method of oxygen analysis was developed rather late during the present research.

E. Metallographic Technique

The method of preparation of the metallographic specimens were described in ANL-5019.(2) The method consisted essentially of grinding on a sequence of Durite wet grinding papers under a stream of water followed by grinding with 14,6 , and 1 micron diamond paste on Mira-cloth. The specimens were electropolished for 10 minutes in an electrolyte containing 5 parts of $85 \%$ phosphoric acid, 8 parts of ethyl alcohol, and 5 parts of ethylene glycol at a current density of 30 milliamp/sq cm, using a stainless steel cathode and a platinum wire anode in contact with the surface of the specimen. The metal was etched electrolytically in a solution of 2 grams citric acid, $0.5 \mathrm{cc}$ nitric acid (sp.gr. 1.42), and $97.5 \mathrm{cc}$ water at 15 milli$\mathrm{amp} / \mathrm{sq} \mathrm{cm}$ current density.

In those cases in which special emphasis was placed on the retention of the inclusions, the polishing with diamond paste was done by hand. It was followed by a short electropolish of only three seconds. This was sufficient to remove a thin deformed surface layer without seriously attacking the inclusions. However, it did not remove all of the polishing scratches. Prolonged electropolishing tends to dissolve the inclusions and leave nothing but cavities the shape of which is frequently determined by the crystallographic structure of the matrix.

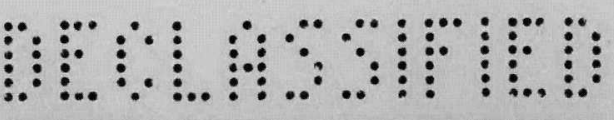




\section{MELTS AND LIQUATIONS}

A. Liquations in Resistance Furnace

1. Liquations in Graphite Crucibles

The first series of liquation experiments was made in a graphite crucible (Table II, p. 43). The following argument was put forward: if the rate of dissolution of carbon in uranium is low, or if a stable continuous compound layer is formed at the interface between melt and crucible, the carbon content of a melt held at constant temperature should not exceed the solubility limit at this temperature, and a reduction of a higher carbon content to the solubility limit should be expected. This, however, did not take place. In four melts, two of them remelts, the carbon content of reactor-grade uranium was not reduced. A heavy monocarbide layer was formed at the top of each ingot (see Chapter VII). This layer, with a carbon content of several thousand ppm, was cropped prior to remelting. The graphite crucible again reacted with the melt at a low temperature, and the result was a metal with a higher rather than lower carbon content than the original metal. The same melts, however, readily lost their nitrogen contamination. The nitrides were collected in the top layer, and metal with less than $10 \mathrm{ppm}$ nitrogen was obtained. No other composition changes occurred, and it should be pointed out that both the iron and silicon content remained unchanged throughout the experiments.

\section{Liquations in Magnesia Crucibles}

When the graphite crucible was replaced by a magnesia crucible, liquation did lower the carbon content of reactor-grade uranium. The carbon content of these melts ranged from 270 to 370 ppm (Table III, p. 44). Variation of time in the molten state had no great effect (compare melt B2 with $\mathrm{Bl} 2$ and B25). A small magnesium addition of $0.1 \%$ (Melt B25), intended to facilitate the carbide liquation by breaking up floating barriers of oxide skins, had no effect, particularly since most of the addition agent was volatilized before the metal was molten. No change in carbon content was noted when biscuit metal was liquated (Melt B20), nor did an increase of the liquation temperature to $1300^{\circ} \mathrm{C}$ with subsequent slow cooling to the freezing point (Melt B24) reduce the carbon concentration. Again the nitrogen content was satisfactorily removed from all of the melts. Only one melt (B25) was analyzed for oxygen. The oxygen content of this melt was of the order of 10 to $15 \mathrm{ppm}$. Some of the magnesia crucibles proved to be a source of silicon contamination.

\section{Liquations in Urania Crucibles}

Liquations in urania crucibles of both reactor grade material and biscuit metal were first made in the vacuum resistance furnace without a cold trap. These experiments were followed by liquations in the present 
system with high pumping speed and equipped with a chevron-type cold trap. They were finally supplemented by a series of melts under socalled standard conditions, $i$. e., conditions under which high purity uranium is melted for minimum contamination. The standard condition is characterized by fast heating, a short time in the molten state, directional solidification, and use of a vacuum system of high pumping speed with a chevron-type cold trap. It would, of course, have been desirable to have these melts made at the beginning of this research. However, since both the conditions and the equipment were the results of the development of high purity uranium, it was not possible to do so. Table IV, p. 45 , lists the results systematically. Group I shows the results of the short-time melts. Remelted biscuit metal usually has a carbon content of up to $30 \mathrm{ppm}$, a nitrogen content of up to $15 \mathrm{ppm}$, and a small amount of oxygen of up to $8 \mathrm{ppm}$. Spectrochemically it may show as much as 50 to $70 \mathrm{ppm}$ iron and up to $70 \mathrm{ppm}$ silicon. Other minor contaminants are aluminum $10 \mathrm{ppm}$, magnesium - 5 to $10 \mathrm{ppm}$, manganese $-5 \mathrm{ppm}$, nickel - $10 \mathrm{ppm}$, and at a still lower level chromium - 1 to $3 \mathrm{ppm}$ and copper - 3 to $5 \mathrm{ppm}$. Reactor grade uranium slugs remelted under the same conditions may have a carbon content of 200 to $500 \mathrm{ppm}$, a low nitrogen content frequently of less than $10 \mathrm{ppm}$, and again up to $8 \mathrm{ppm}$ oxygen. Spectrochemically it contains the same contaminants as biscuit metal, with the exception of magnesium, which, by melting in a high vacuum, is significantly lowered to $1 \mathrm{ppm}$ or less. A top layer high in carbon, nitrogen, and oxygen is quickly formed during the few minutes in the molten state.

Liquation at $1190^{\circ} \mathrm{C}$ reduced the carbon content of reactor grade uranium to 210 to $250 \mathrm{ppm}$ (Group II). An increase in the liquation time from 15 minutes to 65 hours apparently did not affect the result. Lower carbon contents were obtained in the experiments of Group III where an attempt was made to liquate close to the freezing point of uranium. Melt B 473 gave an average carbon content of $222 \mathrm{ppm}$ at a temperature of $1145^{\circ}$ to $1155^{\circ} \mathrm{C}$. Melt B 474 was held for 24 hours at $1138^{\circ} \mathrm{C}, 6^{\circ} \mathrm{C}$ above the accepted freezing point of high purity uranium $\left(1132^{\circ} \mathrm{C}\right)$, and was analyzed to have an average carbon content of $174 \mathrm{ppm}$. Melt B477 was cycled around the melting point simulating repeated thermal analyses at a rate of $0.67^{\circ}$ per minute for both heating and cooling. The upper limit of each cycle was $1138^{\circ} \mathrm{C}$, the lower limit, $1118^{\circ} \mathrm{C}$. These limits were chosen to include the temperature of $1125^{\circ} \mathrm{C}$ observed as a melting point of impure uranium by Dahl and Cleaves. (3) Forty-three minutes of constant temperature at either the lower or the upper level were allowed between heating and cooling or between cooling and heating. The melt was heated 9 times and cooled 10 times during a 23-hour period. In this experiment the carbon content was reduced from about $240-295 \mathrm{ppm}$ to $125-145 \mathrm{ppm}$, the lowest ever obtained in these liquation experiments. 
These liquations were supplemented by liquations of biscuit metal low in carbon. At the time of the experiments it was felt that it might be easier to remove a small quantity of carbon than the higher carbon concentrations of reactor grade uranium. Although in three of these experiments (Group IV and Group V, Melts B250 and B281) the carbon content of the original material was reduced, the low concentrations of 5 to $7 \mathrm{ppm}$ reported by Dahl and Cleaves were never attained. In a material of as low a carbon content as Melt B332 no change in carbon content was noted, although at that time the carbon analytical method was already brought to a high degree of perfection. An anneal of three hours at $1000^{\circ} \mathrm{C}$ prior to melting (Melt B281) did not influence the result of the liquation experiment.

\section{B. Melts in Induction Furnace}

\section{Melts in Magnesia and Urania Crucibles}

The induction furnace melts were vigorously stirred and intimate contact between melt and crucible was made; the results were quite different from those reported in the preceding chapters. On melting in a urania crucible (Table V, p. 47, Melts B82 and B88) no reduction of the carbon content comparable to that of short time melts in the resistance furnace occurred. A reduction of the nitrogen content was incidental to sampling, as the nitrides were not uniformly distributed in the se melts. The same applied to short time melts in a magnesia crucible (B6 and B8). The carbon content, however, was substantially reduced when the metal was kept molten in a magnesia crucible for a relatively long time. In one case (B79) the carbon content was reduced to about $200 \mathrm{ppm}$ in 3 hours, in another case (B77) to about $90 \mathrm{ppm}$ in 4 hours. Simultaneously the nitrogen content dropped to less than $10 \mathrm{ppm}$. Oxygen analyses were not yet available at that time. The oxygen analytical data of Table IV, p. 45, were only recently obtained. Oxidation of the carbide is presumably the process by which the carbon content was reduced. No increase in silicon contamination was noted in these experiments.

\section{Melts in Helium and Hydrogen Atmosphere}

The helium and hydrogen atmosphere melts were short-time induction melts in magnesia crucibles. Melting in a helium atmosphere had no effect on the composition of the metal, neither had the hydrogen atmosphere (Table VI, p. 48). To circumvent a hydride formation at low temperatures and the difficulties related to melting a hydride or metal powder, the charge was melted in a vacuum of 25 or 30 microns, the vacuum replaced by helium, and the helium subsequently by hydrogen. Hydrogen dissolution in the molten metal was indicated by a violent gas evolution during solidification. No change in carbon content was noted; this discouraged further experiments with hydrogen gas. 


\section{Melts in Various Crucible Materials}

Although urania crucibles appeared to be most satisfactory for the liquation experiments, other crucible materials were tested occasionally, and melts were made in tantalum metal, alundum, lime, zirconia, and titanium carbide under a variety of conditions (Table VII, p. 49). The tantalum crucible withstood the attack by the melt for only a short time, although the metal was kept molten for 6 hours. The melt actually was held in the protective alundum crucible surrounding the tantalum cup, and both the aluminum and silicon pickup could be traced to this source. The reduction of the carbon content by tantalum was later investigated by a separate series of experiments. About one-half of the carbon content was removed by the present experiment. The tantalum content of the melt was estimated by semiquantitative spectrographic analysis to be less than $0.1 \%$.

An alundum crucible resisted the attack by the melt for a long period of time. A liquation melt of 48 hours at $1140^{\circ} \mathrm{C}$ reduced the carbon content to $180 \mathrm{ppm}$ in agreement with similar melts in urania crucibles (compare Melt B87 of Table VII, p. 49, with Group III of Table IV, p. 46). However, $200 \mathrm{ppm}$ aluminum were dissolved in the melt so that no advantage could be derived from the use of an alundum crucible material.

A small lime crucible of 100-gram capacity was charged with 58 grams of Hanford metal and very slowly heated by induction to the melting point of uranium within a period of 2 hours. The crucible broke as soon as the uranium was molten. The melt wet the crucible very well; the corrosive attack of the molten metal on the crucible was obviously the cause of the failure.

The corrosion resistance of a stabilized zirconia crucible was fair when Hanford metal was induction melted for 10 minutes at $1300^{\circ} \mathrm{C}$. No reduction of the carbon content was noted; however, 80 to $100 \mathrm{ppm}$ of zirconium were picked up during this short time.

A substantial contamination with both titanium and carbon was observed when high purity electrolytic crystals were melted in a titanium carbide crucible for $1 / 2$ hour at $1250^{\circ} \mathrm{C}$.

C. Melts and Liquations with Nitrogen Additions

1. Melt in Nitrogen Atmosphere

The first melt to which nitrogen was added was an induction melt in a magnesia crucible. The metal was melted in vacuo, the vacuum replaced by an argon atmosphere, the argon by tank nitrogen. Immediately after the admission of nitrogen into the furnace, a solid layer was formed on top of the melt, ending the contact between gas and metal and interfering with the addition of more than a small quantity of nitrogen. This experiment is described in Table VIII, p. 50. 


\section{0 \\ 2. Induction Melts with Uranium Nitride in Magnesia Crucible}

Since a satisfactory nitrogen introduction could not be accomplished by superficial nitriding with gaseous nitrogen, solid uranium nitride was used for nitriding. The uranium nitride powder was prepared from a selected biscuit metal and purified nitrogen. Tank nitrogen was purified in a train consisting of a tube with copper oxide at $600^{\circ} \mathrm{C}$, two drying towers filled with silica-gel and Dririte, two towers with Ascarite, and a tube with uranium nitride at $700^{\circ} \mathrm{C}$ for oxygen removal. The nitriding tube proper containing the uranium chips in a quartz boat was held at $700^{\circ} \mathrm{C}$. An empty protection flask and a tell-tale completed the train. Later this train was simplified for use with purified tank nitrogen to contain only one drying tower with Dririte, another one with phosphorus pentoxide and a tube with copper at $500^{\circ} \mathrm{C}$. The nitriding temperature was raised to $775^{\circ} \mathrm{C}$ to provide for a more rapid and thorough disintegration of the uranium chips. The results obtained from the first train were better than those from the second train inasmuch as the total concentration of uranium and nitrogen by chemical analysis ranged from 99.7 to $99.9 \%$ in the first case, but was 99.1 to $99.5 \%$ in the second case. The nitrides varied in composition from $\mathrm{UN}_{1.52}$ to $\mathrm{UN}_{1.74}$, but probably were decomposed to UN by the time they had been heated to the melting point of uranium.

The nitride additions were first made in a series of experiments in which quantity, time, and temperature were varied. The nitride powder was placed in the bottom of a magnesia crucible (satisfactory urania crucibles were not yet available at that time) and a uranium slug, which was machined to conform to the shape of the crucible, was placed on top of it. The slugs were vacuum melted by induction. These nitriding experiments are listed in Table IX, p. 51. Although the melts were vigorously stirred, some uranium nitride usually remained at the bottom of the crucible and only in one case (Melt B41) all of the nitride was used up when no more than $0.1 \%$ nitride was added to the melt. The difficulty of making nitrogen enter the melt persisted throughout all of the nitriding experiments. The most successful ones were those in which $2 \%$ of nitride was added and the metal was kept molten for about one-half hour (B37 and B48). The nitrogen distribution in the metal was not uniform at all. The nitriding experiments listed in Table IX, p. 51, did not produce a metal of substantially lower carbon content than that of the original biscuit metal. The carbon reduction of the Hanford Melt B76 was perhaps the result of nitriding, or may have been the result of oxidation similar to that experienced with Melts B77 and B79 in Table V, p. 47 .

\section{Induction Melts with Uranium Nitride in Urania Crucible}

The magnesia crucible was replaced by a urania crucible and a series of nitriding experiments were made at increasing times and temperatures (Table X, p. 52). Melt Bl01 was the only one of this series where all of the $0.2 \%$ nitride addition was absorbed by the melt. It required

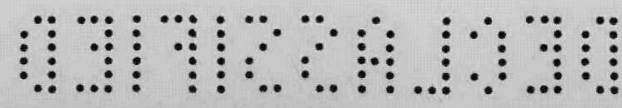


$2-1 / 2$ hours at $1450^{\circ} \mathrm{C}$ to do so. However, the nitrogen content of the resultant ingot was no higher than that of the charge. A layer of nitride inclusions was metallographically located at the ingot top and signified that the nitride was removed as fast as it entered the melt. The nitriding experiments in urania crucibles did not lower the carbon content of the Hanford material any more than the one made in a magnesia crucible.

\section{Liquations of Separately Nitrided Uranium}

The first indication that liquation after nitriding would remove carbon from uranium was obtained when the nitrided alloy of Table VIII, p. 50, was liquated under rather poor conditions of vacuum and pumping speed (Table XI, Group I, p. 53). This result could have been influenced by the oxidizing effect of the magnesia crucible. Subsequently liquations in urania crucibles were made and low carbon concentrations were obtained when the time of liquation was long enough (15 to 44 hours), this notwithstanding the fact that the vacuum system was not equipped with a cold trap (Table XI, Group II, p. 53 ). A similar long time liquation without a preceding nitriding treatment did not reduce the carbon content below $30 \mathrm{ppm}$ (Table IV, Group IV, p. 46). When Hanford metal was substituted for biscuit metal the carbon content was reduced to about 200 ppm after 24 hours, and to 120 to 135 ppm after 68 hours (Table XI, Melts Bl34 and B98, p. 53 ).

\section{One Step Nitriding and Liquation Melts}

Experiments to nitride and liquate in one step produced no better results than those described heretofore (Table XII, p. 54). Melt B24l was one where the furnace system was equipped with a cold trap and optimum conditions with respect to vacuum and pumping speed were obtained. The uranium nitride was placed in a small cavity, a well, inside the biscuit metal charge, out of contact with the crucible wall. The carbon content of this melt was reduced from $40-50$ to $27 \mathrm{ppm}$.

\section{One Step Nitriding and Liquation Melts with Calcium Additions}

Finally, a series of melts was made where a small quantity of calcium was added to the charge in an attempt to facilitate the incorporation of the nitride into the metal (Table XIII, p. 55). None of the se experiments had the desired results and none produced metal of very low carbon content. The nitriding experiments were discontinued when it became obvious that low carbon concentrations were obtainable only under uncertain nitriding conditions and long subsequent periods of liquation.

D. Melts with Alloying Additions

1. Melts with Tantalum, Titanium and Zirconium

The compilations of thermodynamic data by Kelley, (10) Brewer, Bromley, Gilles, and Lofgren, (11) and Kubaschewski and Evans, (12) and 
the recent experimental determinations by Humphrey $(13,14)$ indicate the stability of $\mathrm{TaC}, \mathrm{TiC}$, and $\mathrm{ZrC}$ in the presence of UC (Table XVI, p. 58). Although the data for UC are hardly more than estimates, it is felt that Brewer's (15) earlier estimate of $30,000 \mathrm{cal}$ for $\Delta \mathrm{H}_{298}$ is more nearly correct than the later published value of $40,000 \mathrm{cal}$. Since $\mathrm{TaC}, \mathrm{TiC}$ and $\mathrm{ZrC}$ have a lower density than molten uranium, their successful removal from uranium hinges upon their solubility limits near the melting point of uranium. None of these solubility limits are particularly low and complete removal of carbon from uranium by means of tantalum, titanium or zirconium cannot be expected unless ternary compounds of lower solubility are formed. A ternary compound, $\mathrm{UTa}_{10} \mathrm{C}_{4}$, was observed in the uranium-tantalum-carbon system and used to effect carbon removal.

To test the feasibility of carbon removal by any one of the aforementioned addition agents, two series of experiments were performed. Small additions of tantalum, titanium, and zirconium were made to both Hanford and biscuit metal and the melts liquated for 15 to 24 hours (Table XIV, p. 56). These operations did not lower the carbon content of the metal below the limits that were obtainable without the use of the addition agent. Enough of the addition agents entered the melt to contaminate the metal more than was gained by the carbon removal.

\section{Melts Stirred with Tantalum Rod}

In another series of experiments the melts were stirred by a tantalum rod. The stirring rod, suitably bent to permit a circular motion in the melt, was attached to a stainless steel rod. This rod entered the vacuum furnace through a Wilson seal and could conveniently be pushed down, rotated, and withdrawn. This was done manually both in the induction furnace and later, for better temperature control, in the resistance furnace. Melts were first made with biscuit metal and the stirring time varied from 1 to 3 to 9 minutes. After 9 minutes the tantalum pickup reached $3000 \mathrm{ppm}$. No reduction of the carbon content was observed (Melts B141, B140 and B143, Table XV, p. 57). In two Hanford melts stirred for 1 and 3 minutes, the carbon content was reduced to $130 \mathrm{ppm}$ after the 3 minute stirring period. The tantalum pickup was still below the limits of spectrochemical detection of 100 ppm (Melts B146 and Bl45). Two subsequent melts of biscuit metal in the resistance furnace at the closely controlled temperature of $1190^{\circ} \mathrm{C}$ produced a small reduction of the carbon content. The 5-minute stirring period of Melt Bl65 contaminated the metal with $150 \mathrm{ppm}$ tantalum. The stirred melts had a high nitrogen and oxygen content which was not found in the liquations of Table XIV, p. 56.

The results discouraged further experiments with tantalum, titanium and zirconium as a means of purification primarily because the attained purification was insufficient in view of the contamination with the addition agents. 


\section{METALLOGRAPHY}

A. Metallography of Project Grade Uranium

1. Phases in Uranium

Metallurgical refining processes are primarily evaluated on the basis of composition changes determined by chemical and spectrochemical analysis. Composition changes, however, do not necessarily satisfactorily describe the effect of a particular refining operation. Aside from physical property changes which are outside the scope of the present work, the macro and microdistribution of the impurities are often greatly affected. The presence of an impurity in solid solution, as an intermediate compound, or of a nonmetallic impurity are of great interest. On first approximation, a pure metal may be defined as one in which all of the impurities are in solid solution. Such a state will rarely be attained, but it does signify a very high degree of purity of a metal whose solid solubilities are low. Since this is the case of uranium, the metallographically observed quantities of second phases are a measure of its purity. Metallography, therefore, was a good tool for evaluating the usefulness of a particular refining operation and consequently, the present work was accompanied by a large number of metallographic examinations.

The major contaminants of uranium are carbon, nitrogen, and oxygen and to a lesser degree iron and silicon. Hardly any information is available on the solubility limits of these elements in the solid state. The liquation experiments of Table IV, Group III, p. 46, indicate that the solubility limits for carbon, nitrogen and oxygen near the melting point of uranium are less than $175 \mathrm{ppm}$, less than $10 \mathrm{ppm}$, and less than $4 \mathrm{ppm}$, respectively. The solubility limits of silicon were determined to be 2095 ppm in gamma uranium at the temperature of $980^{\circ} \mathrm{C}$ and less than $1200 \mathrm{ppm}$ in beta uranium at $750^{\circ} \mathrm{C} .(16)$ It is estimated from grain-coarsening experiments that the solubility of silicon in alpha uranium is perhaps less than $20 \mathrm{ppm}$. The solubility of ir on in gamma uranium reaches a maximum of about $4800 \mathrm{ppm}$ at $850^{\circ} \mathrm{C}(17,18)$ and was termed practically negligible in alpha and beta uranium.

The phases that are considered to be in equilibrium with alpha uranium are $\mathrm{UC}$, UN, UO, $\mathrm{U}_{3} \mathrm{Si}_{2}$ and $\mathrm{U}_{6} \mathrm{Fe}$. Other compounds that may be present are residual reaction products of the bomb reduction process, such as magnesium fluoride, uranium fluoride, and smaller quantities of magnesium oxide and calcium oxide. A few particles of uranium dioxide may exist in the metal in nonequilibrium.

Most of the ingots were examined as furnace cooled. Under these conditions the uranium should be in the alpha form. 


\section{4 \\ 2. Microstructure of Biscuit Metal and Remelted Biscuit Metal}

The materials with which the present experiments were made were biscuit metal and Hanford slugs or slug rejects (see Chapter II-C). The structure of biscuit metal is shown in Figure 1, p. 72. The etched microstructure shows alpha uranium crystals with deformation twins and a network of fine precipitate which responds to solution heat treatment in the gamma range and has previously been described in ANL-5019. (2) The black particles of Figure 1 shown as polished in Figure 2, p. 72, at low magnification and in Figure 3, p. 72 at high magnification are either angular inclusions, probably primary crystals of $U C$ and $U N$ or $U[C, N]$, or saltlike round and oblong inclusions of $\mathrm{MgF}_{2}$ or $\mathrm{UF}_{3} . \mathrm{MgF}_{2}$ has positively been identified by X-ray diffraction. (19) The salt inclusions of $\mathrm{MgF}_{2}$ and the angular primary crystals can be distinguished after careful hand polishing and an electrolytic polish of 3 seconds only. They lose their identity after prolonged electrolytic polishing and etching. The salt inclusions are frequently found at the alpha grain or subgrain boundaries (Figure 4, p. 72). Figure 4 shows the microstructure of a biscuit produced in 1953, whereas the microstructure of Figure 1, p. 72 belongs to a biscuit made in 1949. The greatly reduced number of angular inclusions in the 1953 metal reflects the quality improvements made during the past years, particularly with respect to carbon content. (See Table I, p. 42 and compare Figure 5 with Figure 2 and Figure 6 with Figure 4, p. 72.)

If biscuit metal is melted in a good vacuum under conditions similar to those employed for the melting of high purity electrolytic uranium crystals, it loses most of its salt inclusions (Table IV, Group I, p. 45 and Figures 7 and 8 , p. 73). Such metal contains but a few angular inclusions in a matrix of alpha uranium and precipitate.

\section{Microstructure of Hanford Slugs and Remelted Hanford Slugs}

Similar observations were made when rolled and beta-treated reactor grade uranium was remelted and solidified in a good vacuum (Table IV, Group I, p. 45; Figures 9 to 13, p. 74). Since reactor grade material is produced by melting biscuits in graphite crucibles at pressures of from 10 to 500 microns and the melting procedure is fitted into an 8 -hour cycle which limits the time in the molten state, the metal picks up carbon and loses much, but not all, of its salt content. The angular inclusions, which in view of the composition of the metal are essentially carbides, and the residual salt content of the metal are concentrated in the striations shown in Figures 9 to 11 , p. 74 . Remelting the slugs under high purity metal melting conditions breaks up the striations and results in a salt-free material (Figures 12 and 13,p. 74). Slug rejects and acceptable slugs behave alike. Figures 14 to 16, p. 74 show the results obtained on a Fernald slug reject. These structural changes occur in uranium that is melted in the comparably inert urania crucible material. 
The structures shown in Figures $7,8,12,13,15$ and 16, pp. 73-74 form the base line for the evaluation of the structural changes that were produced by the various experimental refining operations of the present research.

\section{B. Effect of Liquation on Microstructure}

\section{Liquation in Graphite Crucible}

Melting in a graphite crucible greatly increased the number of carbide inclusions. The top of ingot K5 (Table II, p. 43) contained a layer of loosely packed round particles (Figure 17, p.75). They were followed by an accumulation of dendritic shapes (Figure 18, p.75) which, near the boundary of the liquation layer, changed into the angular shapes (Figure 19, p.75). The boundary between the top layer and the bulk of the ingot was fairly well defined. The ingot material itself contained many angular inclusions (Figure 20, p. 75) and very much precipitate (Figure 21, p. 75). The heavy concentration of carbides in a top layer of several thousand ppm carbon content is typical of the metal melted in a graphite crucible and so is the structure of the ingot proper with carbon contents ranging from 450 to $750 \mathrm{ppm}$.

\section{Liquation in Magnesia Crucible}

Although liquations in a magnesia crucible indicated a limited removal of carbon from reactor grade uranium (Table III, p.44), no improvement of the microstructure was noted. The carbides were collected in a liquation layer, the very top of which consisted of solidly packed particles (Figure 22, p.76). The number of inclusions in the ingots was hardly different from that in the original material (Figure 24, p.76). Magnesiamelted uranium contains more precipitate than metal melted in urania. Characteristic microstructures are shown in Figures 25 to 27, p. 76 . Since the first melt was made in a rather poor vacuum, surface films were formed on the charge, were trapped in the melt, and persisted throughout the 6-hour melting period (Figure 23, p. 76). Such films may form an effective barrier both to the liquation of inclusions in a melt and to the fusion of the parts of a charge into a homogeneous melt. The prevention of film formation makes good vacua mandatory in uranium melting practice.

\section{Liquation in Urania Crucible}

Metallographic examination of the liquations in urania refractories first indicated that sources other than the crucible material could badly contaminate the metal. Prolonged liquations of Hanford metal in a vacuum furnace without a cold trap reduced the number of the angular carbide inclusions, produced larger inclusions and simultaneously increased greatly the amount of precipitate. The structures obtained after 24 and 65 hours of liquation are shown in Figures 28 and 29, p. 77 . None of these metals contained a significant quantity of nitrogen or oxygen (Table IV,

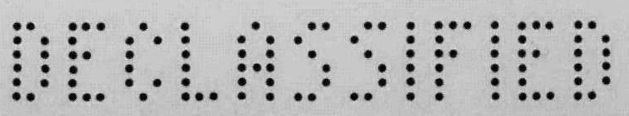


Group II, p. 45); since all of the spectrochemically determined impurities did not vary much from ingot to ingot, the observed structural changes must necessarily have been the effect of the carbon content and its dis tribution in the metal. The increase in inclusion size and the profuse quantities of precipitate were not observed after the vacuum furnace had been equipped with a cold trap (Figures 30 to 33, p. 77; Table IV, Group II, p. 45) although a Widmanstatten pattern of precipitation was formed in the 23-hour melt B474 (Figure 31, p. 77). Similarly, liquation of biscuit metal in a system without a cold trap brought about larger inclusions and more precipitate (Figure 34, p. 78 and Table IV, Group IV, p.46). A biscuit metal that was liquated for 5 hours at $1135^{\circ} \mathrm{C}$ in a system with a cold trap had more precipitate than biscuit metal that was kept molten for only a short time (compare Figure 36, p. 78 with Figure 8, p. 73 ). Liquated biscuit metal had no well-defined top layer of UC, UO, and UN inclusions, but rather a loose aggregate of clusters (Figure 35, p. 78). Some of these clusters adhered to the crucible wall. In general, the number of inclusions retained in the bulk of the ingot decreased but slightly in an irregular fashion from the top to the bottom, emphasizing the slow rate at which these particles floated to the top.

C. Effect of Induction Melting on Microstructure

\section{Melting in Magnesia and Urania Crucibles}

Induction-melted material had a much larger number of inclusions than metal melted in a resistance furnace regardless of the crucible material employed and the vacuum attained. This applied particularly to a metal of high carbon content (Figures 37 to $44, p .79$ ). It is probable that the increase in the inclusion content was the result of the reaction of the melt with the crucible material (Figures 37 and 40, p. 79) and subsequently rapid distribution of the reaction products in the melt by the vigorous stirring effect of the induced current. Since oxygen analyses were not available at the time of the experiments, it was then assumed that the ingots had a high oxygen content; this was confirmed by recent oxygen analyses (Table V, p.47). Since the oxygen content was an order of magnitude lower than the carbon content, it is not surprising that the number of inclusions decreased with carbon content. The larger inclusions of dendritic shape had a strong tendency to float to the top and consequently the upper portions of an ingot showed many more dendrites than its lower parts (Compare Figure 39 with 38, p. 79 and Figure 42 with 41 , p.79). The formation of a top layer resembled that of a resistance furnace melt even though the melts were inductively stirred and rapidly solidified (Figure 45, p. 80). Usually these induction melts were solid within a minute after the power had been turned off. The ingots had very much precipitate (Figures 46 to 49, p. 80). The use of urania in place of magnesia crucibles did not influence the result (Figures 48 and 49, p. 80 ). 


\section{Melting in Helium and Hydrogen Atmosphere}

The observations which were made on vacuum induction melts in magnesia crucibles apply also to similar melts in helium or hydrogen atmosphere. The distribution of the inclusions followed the pattern described in the preceding chapter. In melts B13 and B14 (Table VI, p. 48), however, the dendritic inclusions in the bulk of the ingot appear to be broken into smaller fragments (Figures 50 and 51, p.81). This did not occur in melt B15, where the center of the ingot contained angular inclusions (Figure 52, p.81).

\section{Melting in Various Crucible Materials}

The microstructures that appeared when Hanford uranium was melted in a tantalum crucible are shown in Figures 53 to 55, p. 82 and Table VII, p. 49. The tantalum crucible was intergranularly attacked by the molten uranium (Figure 53, p.82). A slight accumulation of angular carbide inclusions was found near the ingot top (Figure 54, p. 82), but the rest of the metal contained a flake-like constituent of unknown composition (Figure 55, p. 82).

A 48-hour liquation in an alundum crucible made the metal appear rather badly contaminated with much precipitate (Figures 56 and 57, p. 82). The concentration of inclusions in a top layer was similar to that of melts in urania. Many angular inclusions still remained in the metal. The large amount of precipitate is at least partially caused by the aluminum pickup of $200 \mathrm{ppm}$ (Table VII, p. 49).

The calcia crucible melt contained a great many clustered, round inclusions of a slag-like nature aside from the more angular inclusions normally found in uranium (Figures 58 to 60, p. 83). The matrix contained much precipitate in a Widmanstatten pattern characteristic of contaminated metal.

A 10 -minute melt in a zirconia crucible at $1300^{\circ} \mathrm{C}$ changed the microstructure of Hanford uranium. Although it still consisted of primary inclusions in a matrix of uranium with much precipitate, many of the inclusions were small dendrites and the precipitate covered almost all of the matrix (Figure 61, p. 83). These structural changes reflect the contamination of the metal with 80 to $100 \mathrm{ppm}$ of zirconium (Table_VII, Melt B113, p. 49).

Melting of high purity electrolytic uranium in a titanium carbide crucible produced a structure without a precipitate (Figure 62, p. 83). Numerous small inclusions of irregular shape (Figure 63, p. 83) were found in a matrix of alpha uranium. The structural change was caused by a titanium contamination of 500 ppm (Table VII, Melt B153, p. 49) and was similar to the one caused by the addition of tantalum or zirconium reported below (see Chapter IV, E). 
These metallographic examinations confirmed the conclusions that were previously made on the basis of chemical analytical data that none of the aforementioned crucible materials is suitable to contain molten uranium for minimum contamination.

D. Effect of Melting and Liquating with Nitrides on Microstructure

\section{Nitriding}

The metallographic pattern that is set by the nitride additions is very similar for most of the melts. Usually a heavy bottom layer of relatively small rounded particles was attached to the ingot (Figures 64 to 67 , p. 84). The boundary line between the uranium nitride powder and that portion of the uranium nitride which had made contact with the melt is rather uncertain. Out of this bottom layer emerged well-formed cubic or dendritic nitride crystals (Figures 65 and 66, p. 84). However, these crystals did not retain their form for long and underwent a process of dissolution (Figures 67 and 68, pp. $84 \& 85$ ) and bizarre forms were sometimes observed (Figure 69, p. 85). On their way to the top (Figures 71 and . 73, p. 86) they lost their identity and the individual inclusions assumed the form of the angular inclusions commonly observed in reactor grade uranium (Figures 70 and 73, p. 86, compare Figure 73 with Figure 30, p. 77). The distribution of the nitrides is not uniform. They frequently appeared in clusters (Figure 72, p. 86), and the uneven distribution of the nitrides explains the wide spread of chemical analytical data within one sample. When a top layer was formed, it did not differ from other top layers obtained from reactor grade material (Figure 74, p. 86). In this particular instance the dendrites reached up to the top layer and yet the analytical data indicated no more than 100 to $275 \mathrm{ppm}$ nitrogen in a section adjacent to the top layer ( $\mathrm{Table}$ IX, p. 51). In all nitriding experiments the amount of precipitate observed in the etched specimens was greatly increased (Figures 75 to 79, p. 87). In many cases, particularly when the metal was melted in a magnesia crucible, the precipitate covered the entire matrix (Figure 77, p. 87). The nitrogen content of this section did not exceed $85 \mathrm{ppm}$. Melting in urania produced slightly less, yet still plenty of, precipitate (Figure 79, p. 87). The nitrogen content of this sample ranged from 100 to $275 \mathrm{ppm}$. Aside from the se qualitative observations no exact quantitative coordination between microstructure and nitrogen content was possible.

\section{Liquation Subsequent to Nitriding}

Although liquation subsequent to nitriding left a metal with only a few residual inclusions, the metal still contained much precipitate and even the most successful of these liquations (B78 and B80, Table XI, p. 53) were not as clean as should be expected from the analytical data. The characteristic micrographs of this series are shown in Figures 80 to 87 , 
pp. 88-89. Whereas the precipitate in ing ot B65 and B75 (Figures 80 to 83, p. 88) could be attributed to the nitrogen content of the metal of about 50 and $100 \mathrm{ppm}$, respectively, the low nitrogen content of ingots B78 and B80 (Figures 84 to $87, \mathrm{pp} .88-89$ ) precluded this interpretation. Since the carbon content of these ingots was low, it is possible that not only carbon and nitrogen but also iron and silicon contamination manifest their presence in the form of precipitate. That would indicate that the solubility of both iron and silicon in alpha uranium is very low.

\section{One Step Nitriding and Liquation}

The metallography of the series in which nitriding and liqua tion were carried out in one step, added no significant new information. The microsection of such a melt (Figure 88, p.. 89; B81, Table XII) looked hardly different from one obtained by extended liquation without nitrogen addition (compare Figure 88 with Figures 28 and 29, p. 77 ) emphasizing the great difficulty of introducing the nitride into the melt.

\section{One Step Nitriding and Liquation with Calcium Additions}

Some of the melts to which calcium was added showed less precipitate than those of the preceding series (Figure 89, p. 89). Since, however, the composition of these ingots (Table XIII, p. 55) differed insignificantly from ingots which were not nitrided, the continuation of the calcium experiments did not appear promising.

E. Effect of Alloying Additions on Microstructure

\section{Tantalum Additions}

Small addition of tantalum had an important effect on the microstructure of uranium. The addition of about $200 \mathrm{ppm}$ of this element to either Hanford, biscuit, or high purity metal removed any trace of precipitate and made the metal appear clean (Figure 90, p. 90). The effect is independent upon the state of the metal; working and tempering in the alpha range caused no reprecipitation (Figures 91 and 92, p. 90). The effect, therefore, is no solution effect similar to the one observed on uranium on solution heat-treatment in the gamma range and subsequent water quenching (see ANL-5019(2)). The effect may be explained by assuming, in agreement with the thermodynamic data of Table XVI, p. 58, that tantalum carbide is more stable than uranium carbide, and that the solubility of tantalum carbide in uranium is still lower than that of uranium carbide and independent of temperature. All of the carbon should, therefore, be present as a primary compound, and none as secondary precipitate. The same would apply to residual nitrides and oxides. 


\section{Melts Stirred with Tantalum Rod}

On stirring a melt with a tantalum rod, increasing amounts of tantalum were picked up by the metal (Figures 93 to 95, p. 91, and Table XV, p. 57). After 3 minutes at $1150^{\circ}$ to $1200^{\circ} \mathrm{C}$, the effect on the structure just began to appear (Figure 94). In all stirring experiments an intermediate dense compound was readily formed on the surface of the stirring rod, the thickness of which increased with time. The tantalum rod was slowly consumed (Figure 96, p. 92).

\section{Titanium and Zirconium Additions}

The same structural effect was observed when titanium and zirconium were added to uranium (Figures 97 and 98, p. 92, and Table XIV, p. 56). Likewise it occurred when uranium was melted in a titanium carbide crucible, whereby considerable quantities of titanium and carbon were taken up by the melt (Figure 62, p. 83; Melt B153, Table VII, p. 49). The effect was not observed when Hanford metal was melted for 10 minutes in a zirconia crucible, since at $1300^{\circ} \mathrm{C}$ only 80 to $100 \mathrm{ppm}$ of zirconium were taken up by the melt (Figure 61, p. 83). Niobium and hafnium additions have not been investigated. 


\section{DISCUSSION AND CONCLUSIONS}

A. Carbon Removal

The lower limits of carbon content obtainable by liquation of Hanford slugs are:

$\begin{array}{ccc}\text { at } 1190 \text { to } 1200^{\circ} \mathrm{C} & \text { about } & 225 \text { to } 250 \mathrm{ppm} \\ \text { at } 1145 \text { to } 1155^{\circ} \mathrm{C} & \text { about } & 190 \text { to } 225 \mathrm{ppm} \\ \text { at } 1138^{\circ} \mathrm{C} & \text { about } & 170 \mathrm{ppm} \\ \text { at } 1132^{\circ} \mathrm{C} & \text { possibly } & 150 \mathrm{ppm} .\end{array}$

The liquations were made in urania crucibles (Table IV, p. 45), and the data represent an approximation to the liquidus curve of the uranium-carbon alloys in the low carbon range.

No equally low carbon concentrations were obtained by liquation in magnesia crucibles (Table III, p. 44). On the other hand, carbon concentrations of 90 to $200 \mathrm{ppm}$ resulted from induction melts in magnesia but not in urania crucibles when high temperatures and several hours of inductive stirring promoted contact between melt and crucible wall (Table V, p. 47 and Table IX, Group IV, p. 51). A reduction of the number of inclusions coincided with the reduction of the carbon content ( $F$ igures 37 to $44, \mathrm{p} .79$ ). To explain these results it is assumed that the reactions

$$
\begin{array}{ll} 
& 2 \mathrm{MgO}+\mathrm{UC} \longrightarrow \mathrm{UO}+\mathrm{CO}+2 \mathrm{Mg} \\
\text { or } \quad & 3 \mathrm{MgO}+\mathrm{UC} \longrightarrow \mathrm{UO}_{2}+\mathrm{CO}+3 \mathrm{Mg}
\end{array}
$$

proceed in a high vacuum where magnesium, because of its high vapor pressure, is continually volatilized. Magnesium flakes could be seen floating in the vacuum furnace after prolonged melting, and gas bubbles continued to burst from a melt apparently without letup. However, the other reaction products, $\mathrm{UO}$, if it should exist, or $\mathrm{UO}_{2}$, are less readily observed. Oxygen analyses of the interior of magnesia melted uranium produced scattered irregular data (Table V, p. 47). Metallographically, an oxide layer was observed adjacent to the crucible wall and the shape of the round inclusions in its neighborhood was distinctly different from that of the angular inclusions of the interior. The latter may be stained dark gray in an electrolyte of $10 \%$ citric acid at a current density of $15 \mathrm{milliamp} / \mathrm{cm}^{2}$ whereas the monoxide inclusions stay white. The irregularity of the oxygen distribution may be explained to be the composite result of two factors: crucible reaction and liquation. The crucible reaction supplies oxygen, liquation removes the oxide. Because of the inductive stirring effect, no steady state can be attained. 
Liquation and oxidation appear to be the only methods by which carbon can be partially removed. The nitriding and liquating experiments were discouraging inasmuch as they resulted in only a limited removal of carbon from Hanford slugs. Carbon removal from biscuit metal by nitriding and liquation did not produce a metallographically clean metal. Treatment with hydrogen had no effect at all. Since carbon is put into reactor grade uranium by melting in graphite and modern biscuit metal has a very low carbon content, the obvious way of producing low carbon material is to melt in an oxide crucible in a very good vacuum system in which the metal is not contaminated from sources other than the crucible material.

B. Oxygen Removal

Short-time melts in urania show that the oxygen content of biscuit metal or reactor grade uranium is quickly removed by liquation to very low limits and collected in a top layer (see Melts B390 and B405 in Table IV, Group I, p. 45). The particles of such a top layer may be either UO, UC, and UN or their solid solutions. An attempt to distinguish them metallographically in situ gave no satisfactory results. These top layers may also contain dark gray inclusions of $\mathrm{UO}_{2}$.

Debye-Scherrer and back-reflection X-ray diffraction photographs of the top layer gave lines corresponding to the lattice parameters of UC when the metal was liquated in a graphite crucible. Filings from the top layer of urania melted metal gave lines corresponding to the range of the parameters of $\mathrm{UC}, \mathrm{UN}$, and $\mathrm{UO}$ or $\mathrm{U}[\mathrm{C}, \mathrm{N}, \mathrm{O}]$. The presence of $\mathrm{UO}_{2}$ lines in either case may have been caused by $\mathrm{UO}_{2}$ inclusions or by surface contamination incurred during sample preparation (see Appendix, Chapter VII by $\mathrm{M}$. H. Mueller).

The short-time melts and all of the liquation melts in urania ended with a metal low in oxygen. The oxygen content of uranium, therefore, was readily controlled by using urania crucibles and permitting enough time at a constant temperature for the oxides to float to the top. Turbulent stirring and casting will interfere with the process, and the irregular distribution of oxygen in Hanford slugs is the result both of insufficient separation during melting (too short a time in the molten state and stirring effect of the inductive current) and of turbulence and mechanical trapping of already separated inclusions during casting.

\section{Nitrogen Removal}

Similarly to oxygen, nitrogen rises to the top of a melt and forms part of the top layer. Less than $10 \mathrm{ppm}$ of nitrogen are usually left in the melt. If UC, UO and UN should form a continuous series of solid solutions, they do not behave so during liquation. UO and UN rise independently of UC. This did not favor the nitriding and liquating experiments where the nitrogen, 
after having entered the melt, rapidly migrated to the top. If nitrogen was found in an ingot, it was not uniformly distributed, which explains the sometimes wide spread of the nitrogen analytical results (see Table IX, p. 51). It is difficult to judge to what extent reactions like

$$
\text { or } \quad \begin{aligned}
& \mathrm{MgO}+\mathrm{UN} \rightarrow \mathrm{UO}+\mathrm{Mg}+\mathrm{N} \\
& \mathrm{UO}_{2}+\mathrm{UN}-2 \mathrm{UO}+\mathrm{N}
\end{aligned}
$$

may have affected the results of the nitriding melts of Tables VIII, p. 50 and IX, p. 51, although the nascent nitrogen of such a reaction should have combined with uranium to form UN.

D. Removal of Salt and Metallic Impurities

In all cases where uranium was melted in a good vacuum and kept molten for some time, the magnesium or magnesium fluoride content of the metal was reduced almost to the limits of spectrochemical detection. Even uranium melted in magnesia had a consistently low magnesium content. Metallographically no salt inclusions were found in liquated metal. Among the other impurities of high vapor pressure, the manganese concentration was reduced, however, not as much as magnesium; residual manganese concentrations were usually somewhat higher than the magnesium concentrations of the same melt.

Iron and silicon always stayed in the metal, and so did the minor contaminants: aluminum, copper, chromium, and nickel. Only in one case chromium, iron, nickel and silicon were moved when the metal was cycled around its melting point. It is assumed that analogous to zone refining, these elements are concentrated in the top of a melt on directional freezing from the bottom up. Subsequent melting does not restore a homogeneous melt and by repetition of the freezing and melting an effect comparable to zone refining is produced. However, because both liquation and zone refining occur simultaneously, not only the elements with a favorable distribution coefficient $(K<1)$ concentrate at the top end, but also those with an unfavorable distribution coefficient $(K>1)$ provided they can be liquated. In such a way a concentration of almost all of the common impurities of uranium may occur in one end of an ingot. Cycling, therefore, offers interesting possibilities as a high temperature separation process.

\section{E. Composition and Structure}

The number of primary angular inclusions in vacuum-melted and urania-liquated uranium is essentially a function of its carbon content, with nitrogen and oxygen contributing only minor quantities. The angular inclusions are UC. Dendrites occur when the carbon or oxygen contents are high. Aside from such obvious cases when dendritic oxides were found adjacent to the crucible wall or nitrides were forced into the metal, carbides, nitrides, and oxides could not be distinguished in the interior of an 
ingot or in a top layer, although recent work by R. F. Dickerson at Battelle Memorial Institute (20) indicates that some differentiation may be possible.

Whereas the dendritic and angular inclusions are a primary phase, the precipitate is the result of a solid state reaction. All of the more important impurities contribute to the precipitate, which is thought to be the product of the eutectoid decomposition of the gamma phase to beta and subsequently to alpha. All of the contaminants, including $\mathrm{U}_{6} \mathrm{Fe}$ and $\mathrm{U}_{3} \mathrm{Si}_{2}$, behave alike, making the precipitate a sensitive indicator of the purity of the metal in similarly furnace-cooled specimens. Only when all of the contaminants have a low concentration, a material low in precipitate should be expected and only high purity electrolytic uranium is such a material. The presence of precipitate in a metal of low carbon and nitrogen content and probably also of low oxygen content is illustrated in Figures 84 to $87, \mathrm{pp} .88-89$. The precipitate may occur in form of a network, possibly reflecting the grain boundaries of the original gamma grain, or in a Widmanstätten pattern, the latter frequently when the total contamination is high. To what extent and in what way the beta-alpha transformation affects the formation of the precipitate is not known.

Metal with more than $200 \mathrm{ppm}$ of tantalum, titanium, or zirconium contains no precipitate, probably because these elements form very stable primary carbides, oxides, and nitrides which in turn are insoluble in the uranium. matrix.

F. Optimum Melting Conditions for Uranium

Minimum total contamination of reactor grade uranium, either biscuit metal or slugs, is attained when the metal is melted in a urania crucible preferably in a resistance furnace where only thermal convection currents stir the metal (see Note below). The melting temperature should not exceed $1200^{\circ} \mathrm{C}$, both to minimize the reaction with the crucible material and to reduce the temperature dependent solubility of carbon, nitrogen and oxygen in the melt. The metal then should be given enough time in the molten state to allow the salts, the nitrides and oxides, and the insoluble portion of the carbon content to liquate to the top surface. A good vacuum system of high pumping speed is mandatory to remove the gases and vapors from the system. These gases and vapors may evolve from the melt or the furnace materials which readily absorb large quantities of gas. After liquation the metal may be brought to a higher pouring temperature and cast without turbulence. If the metal is permitted to freeze in the crucible using a device of directional solidification, a metal is produced that will contain from 130 to $200 \mathrm{ppm}$ total impurities. This is only two to three times as high as the total for high purity electrolytic uranium which contains a maximum of $70 \mathrm{ppm}$ of impurities.

Note: Recent experiments indicate that high-fired high purity thoria and perhaps beryllia crucibles may be used. 


\section{APPENDIX}

\section{THE CONTROL OF STRINGERS IN REACTOR GRADE URANIUM}

The results of the present work and the method of solution heat treatment described in ANL-5019(2) may be applied to form a process for the control of stringers or striations in reactor grade uranium. The stringers are considered objectionable in fuel elements because they disrupt the continuity of the metal. They may cause considerable difficulties with respect to canning and bonding, and may lower corrosion resistance if they are located at or beneath the surface of a fuel slug. The stringers are irregular rows of separate inclusions of carbides, nitrides, oxides or salts. Careful hand polishing leaves them intact (Figure 11, p. 74). Prolonged electrolytic polishing or etching partially removes them and produces the channel-1ike cavities of Figures 9 and 10, p. 74. For the numerous attempts to identify them individually by metallographic or $\mathrm{X}$-ray diffraction techniques, the report of the meeting of the Metallographic Group held at Battelle Memorial Institute at Columbus, Ohio, on October 27, 1954, should be consulted.

Aside from those inclusions which are lined up in the striations, the slugs contain other angular inclusions in random distribution and the precipitate described above. The precipitate may be brought into solution by heat treating in the gamma range and water quenching (Figure 99, p. 93). Subsequent reheating to $950^{\circ} \mathrm{C}$ and slow furnace cooling will reproduce the precipitate (Figure 100, p. 93). The same heat treatment will partially dissolve the inclusions, both those contained in the striations and those randomly distributed, and will also round them off (Figures 101 and 102, p. 93). How much and how many of them are dissolved will depend on the solubility limits of gamma uranium for carbon, nitrogen, oxygen, and the salts $\mathrm{MgF}_{2}$ and $\mathrm{UF}_{3}$.

Since the oxides, nitrides and salts can be removed by remelting under suitable conditions or by liquation, some of the causes of stringer formations can be eliminated by a suitable melting and liquation process. Yet, a metal containing only carbides will still produce stringers when it is rolled by one of the conventional techniques. If, however, a suitably melted and liquated metal is solution heat treated prior to any rolling, the inclusions will not line up in striations on subsequent $600^{\circ} \mathrm{C}$ rolling. This is shown in the following sequence of photomicrographs. Figures 9 and 10 , p. 74 , represent the starting material. Remelting produced a metal with precipitate and many inclusions in random distribution (Figures 12 and 13, p. 74 ). Annealing for three hours and at $1100^{\circ} \mathrm{C}$ and water quenching dissolved the precipitate and rounded off the inclusions (Figures 103 and 104, p. 94). $600^{\circ} \mathrm{C}$ rolling of the solution heat treated and water quenched ingot produced the structures shown in Figures 105 to 108, p. 94. An ingot of 356 grams of weight was rolled from an average diameter of 1 " by about 
$90.7 \%$ to a slightly oval rod of $0.295^{\prime \prime} \times 0.320^{\prime \prime} \times 16 "$. The metallographic specimens were taken from the center and that end of the rod which originally was the bottom end of the ingot. The rod contained no lined up inclusions at the end of the rod (Figure 105) and only a few lines at the center (Figure 106). After etching, the end of the rod had no striations at all (Figure 107), the center just a few of them (Figure 108). Figure 108, taken at $200 \mathrm{X}$, showed that the precipitate began to reappear as individual particles rather than as a network (note the tiny dots both at the grain boundaries and within the grains).

A similar series was made with a Fernald slug reject as starting material (Figure 14, p. 74). Figures 15 and 16, p. 74, show the metal after remelting and Figure 109, p. 95, after solution heat treatment for 3 hours at $970^{\circ} \mathrm{C}$ and water quenching. This sample was heavily etched to reveal any precipitate that may not have gone into solution. Figures 110 and 111, p. 95, show the structure of the metal after a $600^{\circ} \mathrm{C}$ rolling reduction from an average of $0.994^{\prime \prime}$ diameter to $0.320^{\prime \prime}$ diameter by about $89.6 \%$. The metal contains hardly any stringers although the rod end (Figure 110) appears to be slightly better than the rod center (Figure 111).

The result is possible because reprecipitation of the solute at $600^{\circ} \mathrm{C}$ is slow even during rolling and, if it does occur, the precipitate forms no network. Once formed, the network precipitate is very stable, and rolling forces most of the inclusions within the web to line up with the elongated net itself. The network acts as a barrier to the random distribution of the inclusions, and by breaking it up, the primary cause of stringer formation is removed. Thus, the effectiveness of the procedure depends on three factors:

(1) A heat treatment sufficiently long at a high enough temperature to dissolve all of the precipitate in gamma uranium;

(2) An effective quench;

(3) The timing which places heat-treating and quenching before the deformation.

Whereas Steps 1 and 3 are easily controlled, this is more difficult with Step 2, where the size of the ingot will determine the quenching rate of its interior. In any event, the improvement over the original slug is considerable both as a result of controlled remelting and heat treatment. 


\title{
APPENDIX
}

\section{IDENTIFICATION OF LIQUATION LAYER INCLUSIONS BY X-RAY DIFFRACTION}

\author{
by $\mathrm{M} . \mathrm{H}$. Mueller
}

$\mathrm{X}$-ray diffraction patterns were made of the inclusions found in the top layer of liquated uranium. Debye-Scherer powder diffraction patterns and back-reflection patterns were obtained of this material using a flat cassette. All patterns were taken with $\mathrm{Cu}-\mathrm{K} \alpha$ radiation.

The diffraction pattern obtained from filings taken from the top of melt B2 (see Table II, p. 43 ) showed the presence of very small amounts of $\mathrm{U}$ and $\mathrm{UO}_{2}$ with the main diffraction pattern accounted for by a facecentered cubic phase with an $a_{0}$ in the range previously reported $(6)$ for UN, UO, and UC. There is good evidence in this pattern that the main cubic phase actually consists of at least two face-centered cubic phases with slightly differing $a_{0}$ 's, so that in the back-reflection region for a particular reflection, the $\alpha_{2}$ line from the cubic material with the larger $a_{0}$ overlaps the $\alpha_{1}$ line from the cubic material with the smaller lattice parameter.

Additional filings taken from the top of melt B2 were treated with $20 \% \mathrm{HCl}$. The $\mathrm{X}$-ray diffraction pattern obtained after this treatment was similar to that described above except that the relative amounts of the $U$ had decreased and $\mathrm{UO}_{2}$ had increased.

The back-reflection X-ray diffraction patterns, obtained using the polished surface of the top layer of this same melt, showed the presence of the main face-centered cubic pattern described above with no evidence for the $\mathrm{U}$ or $\mathrm{UO}_{2}$.

The calculated lattice parameters obtained from the Debye-Scherer and back-reflection patterns described above are shown in Table XVIII, p. 58. Very good agreement exists between the $a_{0}$ 's as determined from the powder pattern (Film No. 4065) using either three sets of reflections or the single (620) reflection. The slightly different parameters obtained from the back-reflection photograms may be due to a slight error in the sample to film distance, which was actually measured and not calibrated with a reference material.

When a comparison of the above calculated lattice parameters was made with those reported for UC, UO, and UN, as shown in Table XVII, p. 58 , it was found that the lattice parameters of the unknowns agree quite closely to that of UC. However, since mutual solubility among the 
three compounds has been reported by Rundle et al.,(6) it is possible that the two face-centered cubic phases found in this material, which differed only slightly in parameter, may be primarily UC with some solubility of oxygen and nitrogen, either of which would produce a slightly smaller lattice parameter.

It is interesting to note that an $\mathrm{X}$-ray diffraction powder pattern (Film No. 4065.5) was made of one of the original powder samples of B2 after a lapse of approximately 5 years with the result that the main facecentered cubic phase, previously described, still persisted.

Filings were also obtained from the top layer of liquated slugs B390 and B405 (Table IV, Group I, p. 45) by filing in air. The powder patterns (see Table XIX, p. 58) from these filings showed the presence of $\mathrm{U}, \mathrm{UO}_{2}$, and a face-centered cubic material corresponding to the main phase previously found in slug B2-TL. The patterns obtained from B390-TL and B405-TL differed in several respects from those obtained from slug B2. In the first place the pattern from the $U(C, N, O)$ phase was relatively weak since there was considerable uranium present, and in the second place the pattern from this $\mathrm{U}(\mathrm{C}, \mathrm{N}, \mathrm{O})$ phase did not produce sharp lines in the back-reflection region; hence it was not possible to determine an accurate lattice parameter. However, a rather rough $\mathrm{a}_{0}$, based on the (111) reflection, was obtained for both face-centered cubic phases which appeared in B390-TL and B405-TL. These results, as shown in Table XIX, indicate that the two cubic phases are $\mathrm{UO}_{2}$ and the $\mathrm{U}(\mathrm{C}, \mathrm{N}, \mathrm{O})$ type phase; however, it is not possible to determine the parameter of the latter compound with any degree of accuracy. 


\section{ACKNOW LEDGEMENTS}

This work was initiated by Dr. F. G. Foote, Director, Metallurgy Division, and the author gladly expresses his thanks to him for many fruitful discussions and helpful suggestions.

The first vacuum resistance furnace was built by J. Howard Kittel who, with Edward S. Fisher, made the first series of liquation melts in graphite crucibles. The author acknowledges with pleasure the cooperation of many members of the Metallurgy and Chemistry Divisions. Thanks are due to Ralph W. Bane, Ben D. Holt, and Mrs. Mary Lou Rauh for the chemical analyses; to Frank S. Tomkins and Joseph A. Goleb for the spectrochemical analyses; and to Melvin $H$. Mueller for the X-ray diffraction work. William Lehrer did the early metallographic work on inclusions in uranium which was then continued by Mrs. ShirLee Hayes and Brewster S. Allen. Philip J. Burke assisted in setting up the vacuum melting equipment and making the melts. The author is grateful for the help and advice by Richard J. Dunworth and Dr. H. H. Chiswik. 


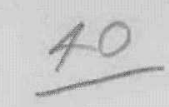

\section{REFERENCES}

1. R. A. Noland and C. Marzano, "The Electrolytic Refining of Uranium," ANL-5102 (Aug., 1953).

2. B. Blumenthal, "The Melting of High Purity Uranium," ANL-5019 (1952).

3. A. L. Dahl and H. E. Cleaves, "The Freezing Point of Uranium," J. Research Natl. Bur. Standards, 43, 513-517 (1949).

4. A. I. Snow, CT-954 and CT-1102.

5. L. M. Litz, A. B. Garrett, and F. C. Croxton, "Preparation and Structure of the Carbides of Uranium," J. Am. Chem. Soc., $\underline{70}$, 1718-1723 (1948).

6. R. E. Rundle, N. C. Baenziger, A. S. Wilson, and R. A. McDonald, "The Structures of the Carbides, Nitrides, and Oxides of Uranium," J. Am. Chem. Soc., 70, 99-105 (1948).

7. C. H. Schramm, P. Gordon, and A. R. Kaufmann, "The Alloy Systems of Uranium-Tungsten, Uranium-Tantalum, and TungstenTantalum, J. of Metals, 188, 203 (1950).

8. R. E. Corwin and G. B. Eyerly, "Preparation of Uranium Dioxide Refractories," ANL-4855 (1952).

9. R. E. Corwin and G. B. Eyerly, "Preparation of Refractories from Uranium Oxide," J. Am. Ceram. Soc., 36, 137-139 (1953).

10. K. K. Kelley, "Contributions to the Data on Theoretical Metallurgy, VII. The Thermodynamic Properties of the Metal Carbides and Nitrides," Bureau of Mines Bulletin No. 407 (1937). "X. High Temperature Heat Content, Heat Capacity, and Entropy Data for Inorganic Substances," Bureau of Mines Bulletin No. 476 (1949).

11. L. Brewer, L. A. Bromley, P. W. Gilles, and N. L. Lofgren, "Thermodynamic and Physical Properties of Nitrides, Carbides, Sulfides, Silicides, and Phosphides, " Paper 4 of The Chemistry and Metallurgy of Miscellaneous Materials, Edited by L. L. Quill, National Nuclear Energy Series, Div. IV, Vol. 19B, McGraw-Hill, New York (1950).

12. O. Kubaschewski and E. L. L. Evans, "Metallurgical Thermochemistry," Academic Press, New York (1951). 
13. G. L. Humphrey, "Heats of Formation of Tantalum, Niobium, and Zirconium Oxides, and Tantalum Carbide," J. Am. Chem. Soc., 76, $978-980$ (1954).

14. G. L. Humphrey, "The Heats of Combustion and Formation of Titanium Nitride and Titanium Carbide," J. Am. Chem. Soc., 73, $2261-2263$ (1951).

15. L. Brewer, CC-3234 (1945).

16. B. D. Cullity, "Alloys of Uranium and Silicon, I. The UraniumSilicon Phase Diagram," CT-3310 (1945).

17. A. R. Kaufmann and P. Gordon, "The Uranium-Iron System," CT-1006 (1943).

18. P. Gordon, B. D. Cullity, A. R. Kaufmann, "Report on the UraniumIron Alloy System," CT-1101, 19-23 (1943).

19. C. M. Schwartz and D. A. Vaughn, "The Identification of Inclusions in Derby and Ingot Uranium," BMI-272 (1953).

20. Report to be issued. 
Table II

LIQUATIONS OF HANFORD URANIUM IN GRAPHITE CRUCIBLE

\begin{tabular}{|c|c|c|c|c|c|c|c|c|c|c|c|c|c|c|c|c|c|c|c|}
\hline \multirow{2}{*}{ No. } & \multicolumn{3}{|c|}{ Charge } & \multirow{2}{*}{$\begin{array}{l}\text { Liquation } \\
\text { Schedule }\end{array}$} & \multirow{2}{*}{$\begin{array}{l}\text { Pressure } \\
\text { Microns }\end{array}$} & \multirow{2}{*}{$\begin{array}{l}\text { Furnace } \\
\text { System }\end{array}$} & \multirow{2}{*}{$\begin{array}{c}\text { Sample } \\
\text { Locat ion }\end{array}$} & \multicolumn{2}{|c|}{$\begin{array}{c}\text { Chemical Analysis } \\
\text { ppm }\end{array}$} & \multicolumn{10}{|c|}{$\begin{array}{c}\text { Spectrochemical Analysis } \\
\text { ppm }\end{array}$} \\
\hline & Material & $\begin{array}{c}\text { Composition } \\
\text { ppm }\end{array}$ & $\begin{array}{c}\text { Weight } \\
\text { gms }\end{array}$ & & & & & 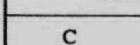 & $N$ & A1 & $B$ & $\mathrm{Cr}$ & 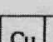 & 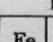 & $\mathrm{ppmim}$ & 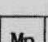 & 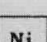 & & Others \\
\hline$K-3$ & $\begin{array}{l}\text { Silug } \\
\text { Reject }\end{array}$ & $\begin{array}{l}\text { C: } 390,735 \\
\text { N: } \quad 39,540\end{array}$ & 3350 & $\begin{array}{l}\text { From m.p. to } 1200^{\circ} \text { in } 4-1 / 2 \mathrm{hrs} \text {; } \\
\text { Furnace cooled }\end{array}$ & 12 to 14 & $\begin{array}{l}\text { Globar Res. } \\
\text { Fce, H-2 } \\
\text { Oil-Diff. Pump, } \\
\text { Glass Cold Trap. }\end{array}$ & $\begin{array}{l}\mathrm{TL} \\
\mathrm{C} \\
\mathrm{B}\end{array}$ & $\begin{array}{rr}5930, & 5385 \\
535 & 505 \\
480 & 475\end{array}$ & $\begin{array}{l}410 \\
<10 \\
<10\end{array}$ & $\begin{array}{l}10 \\
- \\
-\end{array}$ & $\left|\begin{array}{c}<.1 \\
- \\
-\end{array}\right|$ & . & $\begin{array}{l}2 \\
- \\
\cdot\end{array}$ & \begin{tabular}{c|}
20 \\
- \\
-
\end{tabular} & $\begin{array}{l}1 \\
-\end{array}$ & $\begin{array}{l}5 \\
- \\
.\end{array}$ & $\begin{array}{l}5 \\
. \\
.\end{array}$ & $\begin{array}{c}20 \\
.\end{array}$ & - \\
\hline $\mathrm{K}-3$ & $\begin{array}{l}\text { Wlug } \\
\text { Rejeet }\end{array}$ & $\begin{array}{l}\text { Similar } \\
\text { to } K=3\end{array}$ & 3350 & $\begin{array}{l}\text { At } 1180^{\circ} \text { for } 6 \mathrm{hrs} \text {; } \\
\text { Furnace cooled }\end{array}$ & $\begin{array}{c}32 \\
\text { decreas ing } \\
\text { to } 14\end{array}$ & Same & $\begin{array}{l}\mathrm{TL} \\
\mathrm{T} \\
\mathrm{C}_{1} \\
\mathrm{C}_{2} \\
\mathrm{~B}\end{array}$ & $\begin{array}{r}4850 \\
540 \\
660 \\
620 \\
520\end{array}$ & $\begin{array}{l}- \\
271 \\
<10 \\
<10 \\
<10\end{array}$ & $\begin{array}{c}- \\
10 \\
- \\
-\end{array}$ & $\begin{array}{c}- \\
<.1 \\
- \\
-\end{array}$ & $\begin{array}{l}\cdot \\
2 \\
\dot{ } \\
.\end{array}$ & $\begin{array}{l}\cdot \\
1 \\
- \\
- \\
. \\
.\end{array}$ & $\begin{array}{c}. \\
20 \\
- \\
. \\
.\end{array}$ & $\begin{array}{l}\dot{1} \\
\dot{-} \\
-\end{array}$ & $\begin{array}{l}. \\
5 \\
. \\
.\end{array}$ & $\begin{array}{l}. \\
5 \\
. \\
.\end{array}$ & $\begin{array}{c}\cdot \\
20 \\
. \\
\cdot \\
.\end{array}$ & - \\
\hline $\mathrm{K}-5$ & $\begin{array}{l}\text { Remelt } \\
\text { of } \mathrm{K}-3 \\
\text { af ter cropping }\end{array}$ & See $\mathrm{K}-3$ & 2600 & $\begin{array}{l}\text { From m.p. to } 1190^{\circ} \text { in } 1 \mathrm{hr} \text {; } \\
\text { At } 1190^{\circ} \text { for } 2-1 / 2 \mathrm{hrs} \text {; } \\
\text { Furnace cooled }\end{array}$ & $\begin{array}{c}1 \mathrm{hr} \text { at } 30 \\
2-1 / 2 \mathrm{hrs} \text { at } 1000\end{array}$ & Same & $\begin{array}{l}\text { TL } \\
\mathrm{C}_{1} \\
\mathrm{C}_{2} \\
\mathrm{~B}\end{array}$ & $\begin{array}{c}3930,3430 \\
540 \\
550 \\
585\end{array}$ & $\begin{array}{c}79,72 \\
<10 \\
<10 \\
<10\end{array}$ & $\begin{array}{l}10 \\
10 \\
10 \\
10\end{array}$ & $\begin{array}{l}<.1 \\
<.1 \\
<.1 \\
<.1\end{array}$ & $\begin{array}{l}2 \\
2 \\
2 \\
2\end{array}$ & \begin{tabular}{l|}
2 \\
1 \\
1 \\
1
\end{tabular} & $\begin{array}{l}50 \\
30 \\
20 \\
30\end{array}$ & $\begin{array}{l}1 \\
1 \\
1 \\
1\end{array}$ & $\begin{array}{l}7 \\
5 \\
3 \\
5\end{array}$ & $\begin{array}{l}5 \\
5 \\
5 \\
5\end{array}$ & $\begin{array}{l}20 \\
20 \\
20 \\
20\end{array}$ & - \\
\hline $\mathrm{K}-6$ & $\begin{array}{l}\text { Reme } 1 t \\
\text { of } K-4 \\
\text { af ter cropping }\end{array}$ & See K-4 & 1360 & $\begin{array}{l}\text { From m.p. to } 1150^{\circ} \text { in } 1 \mathrm{hr} \text {; } \\
\text { Cooled to } 1050^{\circ} \text {, } \\
\text { Heated to } 1280^{\circ} \text { in } 2 \mathrm{hrs} \text {; } \\
\text { Cooled to } 1220^{\circ} \text {; } \\
\text { Held at } 1220^{\circ} \text { for } 3 \mathrm{hrs} ; \\
\text { Furnace cooled }\end{array}$ & $\begin{array}{c}30 \\
\text { decreas ing } \\
\text { to } 22\end{array}$ & Same & $\begin{array}{l}\mathrm{TL} \\
\mathrm{T} \\
\mathrm{C} \\
\mathrm{B}\end{array}$ & $\begin{array}{c}1725,1785 \\
- \\
- \\
725\end{array}$ & $\begin{array}{l}<10 \\
- \\
- \\
<10\end{array}$ & $\begin{array}{l}- \\
10 \\
10 \\
10\end{array}$ & $\begin{array}{c}- \\
<.1 \\
<.1 \\
<.1\end{array}$ & $\begin{array}{l}- \\
2 \\
2 \\
2\end{array}$ & $\begin{array}{l}- \\
1 \\
1 \\
1\end{array}$ & $\begin{array}{l}- \\
20 \\
30 \\
20\end{array}$ & $\begin{array}{l}- \\
1 \\
1 \\
1\end{array}$ & $\begin{array}{l}- \\
5 \\
3 \\
5\end{array}$ & $\begin{array}{l}- \\
5 \\
5 \\
5\end{array}$ & \begin{tabular}{c|}
- \\
20 \\
20 \\
20
\end{tabular} & $\begin{array}{l}\mathrm{Be}: \\
\mathrm{Be}: \\
\mathrm{Be}:\end{array}$ \\
\hline
\end{tabular}


…:

$\vdots . . .:$ :

......

....:

.....

$\because \because$

$\because \because$

$\because \cdots$.

...:

$\vdots \ldots . .$.

$\therefore .$.

¿...:

…...

Table III

LIQUATIONS IN MAGNESIA CRUCIBLE

\begin{tabular}{|c|c|c|c|c|c|c|c|c|c|c|c|c|c|c|c|c|c|c|c|}
\hline \multirow{3}{*}{ No. } & \multicolumn{2}{|l|}{ Charge } & \multirow{3}{*}{$\begin{array}{l}\text { Liquation } \\
\text { Schedule }\end{array}$} & \multirow{3}{*}{$\begin{array}{l}\text { Pressure } \\
\text { Microns }\end{array}$} & \multirow{3}{*}{$\begin{array}{l}\text { Furnace } \\
\text { System }\end{array}$} & \multirow{3}{*}{$\begin{array}{c}\text { Sample } \\
\text { Locat ion }\end{array}$} & \multicolumn{3}{|c|}{ Chemical Analysis } & \multirow{2}{*}{\multicolumn{10}{|c|}{$\begin{array}{c}\text { Spectrochemical Analys is } \\
\text { ppm }\end{array}$}} \\
\hline & Material & Weight & & & & & ppm & $\mathrm{ppm}$ & $\mathrm{ppm}$ & & & & & & & & & & \\
\hline & & gms & & & & & c & $\mathrm{N}$ & 0 & A1 & B & $\mathrm{Cr}$ & $\mathrm{Cu}$ & $\mathrm{Fe}$ & $M g$ & Mn & $\mathrm{Si}$ & & Others \\
\hline B-2 & $\begin{array}{ll} & (B-1) \\
\text { C: } & 640-745 \\
\text { N: } & <10-33 \\
\text { Fe: } & 20 \\
\text { Si: } & 20\end{array}$ & 320 & $\begin{array}{l}\text { From m.p. to } 1204^{\circ} \mathrm{C} \\
\text { in } 6 \mathrm{hrs} \text {. Furnace } \\
\text { cooled }\end{array}$ & 26 & $\begin{array}{l}\text { Globar Res. Fce. } \\
\text { H-2 Oi 1-Diff. P.; } \\
1395 \text { We lch Forep.; } \\
\text { Glass Cold Trap }\end{array}$ & $\begin{array}{l}\mathrm{T} \\
\mathrm{C} \\
\mathrm{B}\end{array}$ & $\begin{array}{r}1820 \\
370 \\
330\end{array}$ & $\begin{array}{l}258 \\
<10 \\
<10\end{array}$ & & $\begin{array}{l}<_{20} \\
<_{20} \\
<20\end{array}$ & $\begin{array}{l}2 \\
1 \\
.5\end{array}$ & $\begin{array}{l}<1 \\
<1 \\
<1\end{array}$ & \begin{tabular}{l|l}
$<1$ \\
$<1$ \\
$<1$
\end{tabular} & $\begin{array}{r}100 \\
50 \\
50\end{array}$ & $\begin{array}{r}10 \\
<.5 \\
<.5\end{array}$ & $\begin{array}{r}5 \\
10 \\
10\end{array}$ & $\begin{array}{l}30 \\
15 \\
20\end{array}$ & $\begin{array}{l}\text { Be: } \\
\text { Sn: } \\
\text { Sn: }\end{array}$ & $\begin{array}{l}2, \mathrm{Sn}: 10 \\
10 \\
5\end{array}$ \\
\hline B-12 & $\begin{array}{ll}\text { whid } & (\mathrm{B}-9) \\
\mathrm{C}: & 595 \\
\mathrm{~N}: & 98 \\
\mathrm{Fe}: & 15 \\
\mathrm{Si}: & 15\end{array}$ & 320 & $\begin{array}{l}\text { From m.p. to } 1208 \\
\text { in } 4 \mathrm{hrs} \text {. Cooled } \\
\mathrm{s} \text { lowly to } 1180 \mathrm{in} \\
6 \mathrm{hrs.} \mathrm{Furnace} \\
\text { cooled. }\end{array}$ & 14 to 16 & Same & B & 295 & $<10$ & & $<20$ & .3 & 2 & 8 & 70 & $<.5$ & 2 & 150 & Mo: & $50 \mathrm{Ni}: 5$ \\
\hline$B-20$ & 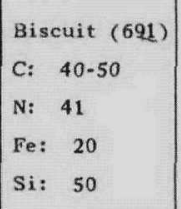 & 320 & $\begin{array}{l}\text { Held at } 1260^{\circ} \text { for } 12 \mathrm{hrs} \text {; } \\
\text { Cooled to m.p. in } 1-1 / 2 \mathrm{hrs} ; \\
\text { Furnace cooled to r.t. }\end{array}$ & 7 & Same & $\begin{array}{l}\mathrm{T} \\
\mathrm{C}_{1} \\
\mathrm{C} \\
\mathrm{B}\end{array}$ & $\begin{array}{r}24,60 \\
30,44 \\
39 \\
115,68 \\
51,58\end{array}$ & $\begin{array}{r}48 \\
13 \\
<10 \\
<10\end{array}$ & & $\begin{array}{l}<20 \\
- \\
<20\end{array}$ & $\begin{array}{l}2 \\
- \\
- \\
.3\end{array}$ & $\begin{array}{l}2 \\
- \\
- \\
2\end{array}$ & $\begin{array}{l}2 \\
\cdot \\
\cdot \\
2\end{array}$ & $\begin{array}{l}50 \\
- \\
- \\
50\end{array}$ & $\begin{array}{l}5 \\
- \\
- \\
5\end{array}$ & $\begin{array}{l}2 \\
- \\
- \\
2\end{array}$ & $\begin{array}{c}300 \\
- \\
- \\
300\end{array}$ & Mo: & 70, $\mathrm{Ni}: 5$ \\
\hline $3 \cdot 24$ & $\begin{array}{l}\text { Biscuit* } \\
\text { (691) }\end{array}$ & 1620 & $\begin{array}{l}\text { Held at } 1300^{\circ} \text { for } 4 \mathrm{hrs} \text {; } \\
\text { Cooled to m.p. in } 1-1 / 2 \mathrm{hrs} ; \\
\text { Furnace cooled to r.t. }\end{array}$ & 10 to 20 & Same & $\begin{array}{l}T_{1} \\
T_{2} \\
B\end{array}$ & $\begin{array}{l}45 \\
25 \\
50\end{array}$ & $\begin{array}{l}37 \\
16 \\
12\end{array}$ & & $\begin{array}{l}<20 \\
<20 \\
<20\end{array}$ & $\begin{array}{l}.2 \\
.3 \\
.1\end{array}$ & $\begin{array}{l}<5 \\
<5 \\
<5\end{array}$ & $\begin{array}{l}2 \\
2 \\
2\end{array}$ & $\begin{array}{l}20 \\
20 \\
20\end{array}$ & $\begin{array}{l}<1 \\
<1 \\
<1\end{array}$ & $\begin{array}{l}6 \\
5 \\
5\end{array}$ & $\begin{array}{l}500 \\
400 \\
400\end{array}$ & $\begin{array}{l}\mathrm{Ni}: \\
\mathrm{Ni}: \\
\mathrm{Ni}:\end{array}$ & $\begin{array}{l}8, \mathrm{~Pb}: 4 \\
15, \mathrm{~Pb}: \quad 2 \\
8\end{array}$ \\
\hline B-25 & $\begin{array}{ll}\text { 뿌 } & (\mathrm{B}-11) \\
+. & 1 \% \mathrm{Mg} \\
\mathrm{C}: & 465 \\
\mathrm{~N}: & 34 \\
\mathrm{Fe}: & 20 \\
\mathrm{Si}: & 15\end{array}$ & 320 & $\begin{array}{l}\text { Held at } 1200^{\circ} \text { for } 24 \mathrm{hrs} \text {; } \\
\text { Furnace cooled to r,t. }\end{array}$ & 0.03 & $\begin{array}{l}\text { Globar Res. Fce. } \\
\text { MCF } 700 \text { Oil-Diff. P. } \\
\text { MB } 100 \text { Booster } \\
556 \text { Kinney Forep. } \\
\text { No cold trap }\end{array}$ & $\begin{array}{l}\mathrm{T} \\
\mathrm{B}\end{array}$ & $\begin{array}{l}300 \\
270\end{array}$ & $\begin{array}{l}<10 \\
<10\end{array}$ & $\begin{array}{ll}16, & 5 \\
10, & 16\end{array} \mid$ & $\begin{array}{l}<20 \\
<20\end{array}$ & $\begin{array}{l}2 \\
1\end{array}$ & $\begin{array}{l}<1 \\
<1\end{array}$ & $\begin{array}{l}5 \\
5\end{array}$ & $\begin{array}{l}20 \\
10\end{array}$ & $\begin{array}{r}<.5 \\
.5\end{array}$ & $\begin{array}{l}1 \\
2\end{array}$ & $\begin{array}{l}200 \\
200\end{array}$ & & - \\
\hline
\end{tabular}

*In MgO Crucible of special manufacture. 
LIQUATIONS IN URANIA CRUCIBLE

\begin{tabular}{|c|c|c|c|c|c|c|c|c|c|c|c|c|c|c|c|c|c|c|c|c|c|}
\hline \multirow{2}{*}{ Group } & \multirow{2}{*}{ No. } & \multicolumn{2}{|c|}{ Charge } & \multirow{2}{*}{$\begin{array}{l}\text { Liquation } \\
\text { Schedule }\end{array}$} & \multirow{2}{*}{$\begin{array}{c}\text { Pressure } \\
\mathrm{mm} \mathrm{Hg}\end{array}$} & \multirow{2}{*}{$\begin{array}{l}\text { Furnace } \\
\text { System }\end{array}$} & \multirow{2}{*}{$\begin{array}{l}\text { Sample } \\
\text { Location }\end{array}$} & \multicolumn{3}{|c|}{$\begin{array}{c}\text { Chemical Analys is } \\
\text { ppm }\end{array}$} & \multicolumn{11}{|c|}{$\begin{array}{l}\text { Spectrochemical Analysis } \\
\qquad \mathrm{ppm}\end{array}$} \\
\hline & & Material & $\begin{array}{c}\text { Weight } \\
\text { gms }\end{array}$ & & & & & $\mathrm{C}$ & $\mathrm{N}$ & 0 & A1 & B & $\mathrm{Cr}$ & $\mathrm{Cu}$ & \begin{tabular}{|l|}
$\mathrm{Fe}$ \\
\end{tabular} & $\mathrm{Mg}$ & Mn & $\mathrm{Ni}$ & $\mathrm{Si}$ & & Others \\
\hline \multirow{3}{*}{ 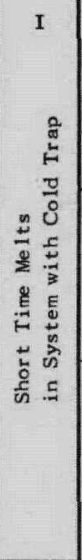 } & B-246 & $\begin{array}{l}\text { Biscuit } \\
\text { (Lot } 691 \text { ) } \\
\text { C: } \quad 40-50 \\
\mathrm{~N}: 40 \\
\mathrm{Fe}: \quad 20 \\
\mathrm{Si}: \quad 50\end{array}$ & 305 & $\begin{array}{l}\text { Heated to m.p. in } 47 \mathrm{~min} \text {; } \\
\text { Held at nom. } 1200^{\circ} \text { for } \\
2 \text { min. } \\
\text { Directionally solidified. }\end{array}$ & $\begin{array}{l}1 \cdot 10^{-5} \\
\max \end{array}$ & $\begin{array}{l}\text { Globar Res. Fce. } \\
\text { MCG } 700 \\
\text { Oi1-Diff. Pump } \\
\text { MB } 200 \text { Booster } \\
\text { Chevron Type } \\
\text { Cold Trap }\end{array}$ & $\begin{array}{l}\mathrm{T} \\
\mathrm{B}\end{array}$ & $\begin{array}{l}24,21 \\
19,16\end{array}$ & $\begin{array}{r}15 \\
8\end{array}$ & $\left|\begin{array}{c}- \\
7,7, \\
4,3\end{array}\right|$ & $\begin{array}{l}10 \\
10\end{array}$ & $\mid \begin{array}{l}<.1 \\
<.1\end{array}$ & $\begin{array}{l}1 \\
2\end{array}$ & $\begin{array}{l}5 \\
5\end{array}$ & $\begin{array}{l}30 \\
30\end{array}$ & $\begin{array}{r}10 \\
5\end{array}$ & $\begin{array}{l}5 \\
5\end{array}$ & $\begin{array}{l}10 \\
10\end{array}$ & $\begin{array}{l}20 \\
20\end{array}$ & Ag: & $\begin{array}{l}\text { 1. } \mathrm{Pb}: 2 \\
\text { 2, } \mathrm{Pb}: 2\end{array}$ \\
\hline & B-390 & $\begin{array}{l}\text { whet }(\mathrm{B}-355) \\
\mathrm{C:} \quad 300-350 \\
\mathrm{~N}: \quad 66 \\
\mathrm{Fe}: \quad 45 \\
\mathrm{Si}: \quad 13\end{array}$ & 535 & $\begin{array}{l}\text { Heated to m.p. in } 40 \mathrm{~min} \text {. } \\
\text { Held at nom. } 1200^{\circ} \text { for } 3 \mathrm{~min} \text {. } \\
\text { Directionally solidified. }\end{array}$ & $1 \cdot 10^{-5}$ & Same & Tl & $\begin{array}{r}2160 \\
200\end{array}$ & $\begin{array}{l}759 \\
<10\end{array}$ & $\begin{array}{l}604, \\
457 \\
8,3\end{array}$ & $\begin{array}{l}7 \\
7\end{array}$ & $\begin{array}{l}<.1 \\
<.1\end{array}$ & $\begin{array}{l}1 \\
1\end{array}$ & 3 & $\begin{array}{r}150 \\
50\end{array}$ & 7 & 2 & 10 & $\begin{array}{l}15 \\
15\end{array}$ & $\begin{array}{l}\mathrm{Na}: \\
\mathrm{Na}:\end{array}$ & $\begin{array}{l}\text { 100, } \mathrm{Pb}: \\
5\end{array}$ \\
\hline & B-405 & $\begin{array}{ll}\text { FLD } & \text { (B-402) } \\
\text { C: } & 325 \\
\text { N: } & 24 \\
\text { O: } & 13-21 \\
\text { Fe: } & 25 \\
\text { Si: } & 25\end{array}$ & 610 & $\begin{array}{l}\text { Heated to m.p. in } 45 \mathrm{~min} \text {. } \\
\text { Held at nom. } 1200^{\circ} \text { for } 5 \mathrm{~min} \text {. } \\
\text { Directionally solidified. }\end{array}$ & $1 \cdot 10^{-5}$ & Same & $\begin{array}{l}\text { TL } \\
\text { T } \\
\text { B }\end{array}$ & $\begin{array}{r}1435 \\
435\end{array}$ & $\begin{array}{r}935 \\
1095 \\
<10\end{array}$ & $\begin{array}{l}721 \\
525 \\
2,2\end{array}$ & $\begin{array}{r}5 \\
10\end{array}$ & $\begin{array}{l}<.1 \\
<.1\end{array}$ & $\begin{array}{l}3 \\
2\end{array}$ & 1 & $\begin{array}{l}30 \\
30\end{array}$ & $\begin{array}{r}40 \\
.5\end{array}$ & 4 & 10 & 30 & & - \\
\hline \multirow{3}{*}{ 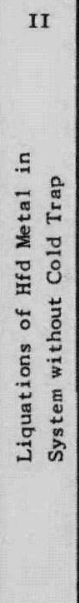 } & B- 67 & $\begin{array}{ll}\text { Ched } & (B-27) \\
\text { C: } & 535 \\
\text { N: } & <10 \\
\text { Fe: } & 30 \\
\text { Si: } & 20\end{array}$ & 156 & $\begin{array}{l}\text { Heated to m.p. in } 31-1 / 2 \mathrm{hrs} \text {; } \\
\text { Heated to } 1190^{\circ} \text { in } 2 \mathrm{hrs} \text {; } \\
\text { Molten at } 1190^{\circ} \text { for } 15 \mathrm{~min} \text {. } \\
\text { Directionally solidified. }\end{array}$ & $\begin{array}{l}1-1.4 \cdot 10^{-5} \\
\text { on heating } \\
\text { decreas ing } \\
\text { be low } 110^{-5} \\
\text { when molten }\end{array}$ & $\begin{array}{l}\text { Globar Res. Fce. } \\
\text { MCF 700 Oi } 1 \\
\text { Diff. P., MB } 100 \\
\text { Booster; } 556 \\
\text { Kinney Forep. } \\
\text { No Cold Trap }\end{array}$ & $\begin{array}{l}\text { C } \\
\text { B }\end{array}$ & 225 & $<10$ & 2,3 & 10 & .2 & $\dot{5}$ & 4 & 100 & $\dot{i}$ & i & ; & 60 & & - \\
\hline & B-96 & $\begin{array}{l}\text { Preme }(B-88) \\
\text { Premed } \\
\text { in } \mathrm{Ajax} \\
\text { at } 1475^{\circ} \\
\mathrm{C}: 475 \\
\mathrm{~N}: \quad 11 \\
\mathrm{Fe}: \quad 20 \\
\mathrm{Si}: \quad 15\end{array}$ & 211 & $\begin{array}{l}\text { Heated to m.p. in } 7-1 / 2 \mathrm{hrs} \text {; } \\
\text { Heated to } 1190^{\circ} \text { in } 2 \mathrm{hrs} \text {; } \\
\text { Molten at } 1190^{\circ} \text { for } 24 \mathrm{hrs} \text {; } \\
\text { Directional1y solidif ied. }\end{array}$ & $\begin{array}{l}\text { about } \\
4 \cdot 10^{-6}\end{array}$ & Same & $\begin{array}{l}c_{1} \\
c_{2}\end{array}$ & $\begin{array}{l}260 \\
240\end{array}$ & $\begin{array}{l}<10 \\
<10\end{array}$ & : & $\begin{array}{l}<20 \\
<20\end{array}$ & $\begin{array}{l}<.1 \\
<.1\end{array}$ & $\left|\begin{array}{l}<1 \\
<1\end{array}\right|$ & $\begin{array}{l}5 \\
2\end{array}$ & $\begin{array}{l}10 \\
10\end{array}$ & $\begin{array}{r}<.5 \\
.5\end{array}$ & $\begin{array}{l}<2 \\
<2\end{array}$ & $\begin{array}{l}5 \\
5\end{array}$ & $\begin{array}{l}5 \\
5\end{array}$ & Ag: & $\begin{array}{l}1 \\
1\end{array}$ \\
\hline & B-83 & $\begin{array}{ll}\text { iHed } & (B-57) \\
\text { C: } & 450 \\
\text { N: } & 64 \\
\text { Fe: } & 20 \\
\text { Si: } & 10\end{array}$ & 246 & $\begin{array}{l}\text { Same as B-96 but liquated } \\
\text { for } 65 \mathrm{hrs} \text { at } 1190^{\circ}\end{array}$ & $\begin{array}{l}\text { about } \\
4 \cdot 10^{-6}\end{array}$ & Same & c & 210 & $<10$ & - & $<20$ & $\mid<.1$ & 1 & 5 & 20 & $<.5$ & .5 & $<5$ & 20 & & - \\
\hline
\end{tabular}




\begin{tabular}{|c|c|c|c|c|c|c|c|c|c|c|c|c|c|c|c|c|c|c|c|c|}
\hline \multirow[b]{2}{*}{ Group } & \multirow[b]{2}{*}{ No. } & \multicolumn{2}{|c|}{ Charge } & \multirow{2}{*}{$\begin{array}{l}\text { Liquation } \\
\text { Schedule }\end{array}$} & \multirow{2}{*}{$\begin{array}{l}\text { Pressure } \\
\mathrm{mm} \mathrm{Hg}\end{array}$} & \multirow{2}{*}{$\begin{array}{l}\text { Furnace } \\
\text { System }\end{array}$} & \multirow{2}{*}{$\begin{array}{l}\text { Sample } \\
\text { Location }\end{array}$} & \multicolumn{3}{|c|}{$\begin{array}{l}\text { Chemical Analys is } \\
\text { ppm }\end{array}$} & \multicolumn{10}{|c|}{$\begin{array}{l}\text { Spectrochemical Analys is } \\
\text { ppm }\end{array}$} \\
\hline & & Material & $\begin{array}{l}\text { Weight } \\
\text { gms }\end{array}$ & & & & & C & N & 0 & A1 & B & $\mathrm{Cr}$ & $\mathrm{Cu}$ & $\mathrm{Fe}$ & $\mathrm{Mg}$ & Mn & $\mathrm{Ni}$ & $\mathrm{Si}$ & Others \\
\hline III & B-473 & $\begin{array}{l}\text { wFa }(B-59) \\
\text { C: } 715 \\
\text { N: } 84 \\
\text { Fe: } \quad 20 \\
\text { Si: } 10\end{array}$ & 331 & $\begin{array}{l}\text { Heated to m.p. in } 2 \mathrm{hrs} \text {; } \\
\text { Molten at } 1145^{\circ} \text { for } 4 \mathrm{hrs} \text {; } \\
\text { and at } 1155^{\circ} \text { for } 2 \mathrm{hrs} \text { and } \\
20 \mathrm{~min}, \text { slowly cooled to } \\
\text { f.p. }\end{array}$ & $\begin{array}{l}\text { From } 3 \cdot 10^{-5} \\
\text { decreas ing } \\
\text { to } 2 \cdot 10^{-6}\end{array}$ & $\begin{array}{l}\text { Globar Res. Fce. } \\
\text { MCF } 700 \text { Oil-Diff. P. } \\
\text { MB } 200 \text { Booster, } \\
556 \text { Kinney Forep. } \\
\text { Chevron Type } \\
\text { Cold Trap. }\end{array}$ & $\begin{array}{l}\text { TL } \\
\text { T } \\
\text { C } \\
\text { B }\end{array}$ & $\begin{array}{l}820 \\
235,240 \\
190,225\end{array}$ & $\mid \begin{array}{ll}610, & 1045 \\
10 & - \\
17\end{array}$ & $\begin{array}{c}1060 \\
3,2,2 \\
-\end{array} \mid$ & $\begin{array}{c}- \\
10 \\
10\end{array}$ & $\begin{array}{l}- \\
.1 \\
-1 \\
.1\end{array}$ & $\begin{array}{l}5 \\
5 \\
5\end{array}$ & $\begin{array}{l}i \\
i\end{array}$ & $\begin{array}{c}- \\
30 \\
\dot{30}\end{array}$ & $\begin{array}{l}\dot{5} \\
2 \\
i\end{array}$ & $\begin{array}{l}5 \\
5 \\
7\end{array}$ & $\begin{array}{c}5 \\
5 \\
10\end{array}$ & $\begin{array}{c}- \\
15 \\
- \\
30\end{array}$ & : \\
\hline 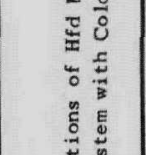 & $B-474$ & $\begin{array}{ll}\text { Heffl } & (\mathrm{B}-55) \\
\mathrm{C}: & 435 \\
\mathrm{~N}: & 66 \\
\mathrm{Fe}: & 15 \\
\mathrm{Si}: & 10\end{array}$ & 308 & $\begin{array}{l}\text { Heated to m.p. in } 40 \mathrm{~min} \text {; } \\
\text { Molten at } 1138^{\circ} \text { for } 24 \mathrm{hrs} \text {; } \\
\text { Cooled slowly to f.p. }\end{array}$ & $\begin{array}{l}\text { From } 3 \cdot 10^{-5} \\
\text { decreas ing } \\
\text { to } 3 \cdot 10^{-7}\end{array}$ & Same & $\begin{array}{l}\mathrm{TL} \\
\mathrm{T} \\
\mathrm{C} \\
\mathrm{B}\end{array}$ & $\begin{array}{l}1230 \\
166,174 \\
173,181\end{array}$ & $\left|\begin{array}{c}1075,745 \\
<10,14 \\
-\cdot \\
<10,13\end{array}\right|$ & $\begin{array}{l}1450 \\
3,3,4\end{array}$ & $\begin{array}{l}10 \\
10\end{array}$ & .1 & $\begin{array}{l}1 \\
1\end{array}$ & $\begin{array}{l}2 \\
2\end{array}$ & 20 & $\begin{array}{l}1 \\
1\end{array}$ & 2 & 5 & 20 & - \\
\hline ב. & B-477 & $\begin{array}{ll}\text { ANL } & B-395 \\
\mathrm{C}: & 240-295 \\
\mathrm{~N}: & <10-16 \\
\mathrm{O}: & 6, \quad 16 \\
\mathrm{Fe}: & 30 \\
\mathrm{Si}: & 15\end{array}$ & 666 & $\begin{array}{l}\text { Heated to m.p. in } 2 \mathrm{hrs} \text {; Held } \\
\text { at } 1138^{\circ} \text { for } 30 \mathrm{~min} \text {; Then cy- } \\
\text { cled around m.p. by cooling } \\
\text { to } 1118^{\circ} \text { at rate of } .67^{\circ} / \mathrm{min} \text {; } \\
\text { Holding at } 1118^{\circ} \text { for } 43 \mathrm{~min} ; \\
\text { Heating to } 1138^{\circ} \text { at rate of } \\
.67^{\circ} / \mathrm{min} \text {; Holding at } 1138^{\circ} \text { for } \\
43 \mathrm{~min} \text {, and so on;Cooling re- } \\
\text { peated } 10 \text { times; Heating re- } \\
\text { peated } 9 \text { times; Total time } \\
23 \text { hrs }\end{array}$ & $\begin{array}{l}\text { From } 2 \cdot 10^{-6} \\
\text { decreasing } \\
\text { to } 2 \cdot 10^{-7} \\
\\
\end{array}$ & Same & $\begin{array}{l}\mathrm{T} \\
\mathrm{C} \\
\mathrm{B}\end{array}$ & $\begin{array}{ll}179, & 182 \\
146, & 147 \\
128, & 122\end{array}$ & $\begin{array}{l}35 \\
13 \\
10\end{array}$ & $\begin{array}{l}2,9 \\
4,5 \\
16,5\end{array}$ & $\begin{array}{l}5 \\
5 \\
5\end{array}$ & $\begin{array}{r}.1 \\
<.1 \\
<.1\end{array}$ & $\begin{array}{l}5 \\
2 \\
2\end{array}$ & $\begin{array}{l}2 \\
2 \\
2\end{array}$ & $\begin{array}{l}50 \\
20 \\
20\end{array}$ & $\begin{array}{l}<_{1} \\
<1 \\
<_{1}\end{array}$ & $\begin{array}{l}2 \\
1 \\
1\end{array}$ & $\begin{array}{l}20 \\
10 \\
10\end{array}$ & $\begin{array}{l}70 \\
30 \\
30\end{array}$ & : \\
\hline 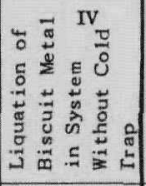 & B- 68 & $\begin{array}{l}\text { Biscuit } \\
\text { (Lot } 687 \text { ) } \\
\text { C: } 48-115 \\
\text { N: } \quad 20 \\
\mathrm{Fe}: \quad 30 \\
\mathrm{Si}: \quad 50\end{array}$ & 211 & $\begin{array}{l}\text { Heated to m.p. in } 7-1 / 2 \mathrm{hrs} \text {; } \\
\text { Heated to } 1190^{\circ} \text { in } 2 \mathrm{hrs} ; \\
\text { Molten at } 1190^{\circ} \text { for } 11 \mathrm{hrs} \text {; } \\
\text { Directionally solidified }\end{array}$ & $\begin{array}{l}\text { about } \\
4 \cdot 10^{* 6}\end{array}$ & $\begin{array}{l}\text { Globar Res. Fce. } \\
\text { MCF } 700 \text { Oil-Diff. P. } \\
\text { MB } 100 \text { Booster } \\
556 \text { Kinney Forep. } \\
\text { No Cold Trap }\end{array}$ & c & 30 & $\begin{array}{c}139,161 \\
\text { (?) }\end{array}$ & - & $<20$ & $<.1$ & $<1$ & 2 & 15 & . .5 & .5 & 10 & 10 & - \\
\hline $\begin{array}{l}\bar{g} \\
\frac{0}{2}\end{array}$ & B-250 & $\begin{array}{l}\text { Biscuit } \\
\text { (Lot } \quad 691 \text { ) } \\
\text { C: } 40-50 \\
\mathrm{~N}: \quad 40 \\
\mathrm{Fe}: \quad 20 \\
\mathrm{Si}: \quad 50\end{array}$ & 305 & $\begin{array}{l}\text { Heated to } 1190^{\circ} \text { in } 50 \mathrm{~min} . \\
1 \text { iquated at } 1190^{\circ} \text { for } \\
5 \text { hrs. } \\
\text { Directionally solidified }\end{array}$ & $2-3 \cdot 10^{-6}$ & $\begin{array}{l}\text { Globar Res. Fce } \\
\text { NCF } 700 \text { Oil-Diff. P. } \\
\text { MB } 200 \text { Booster } \\
556 \text { Xinney Forep. } \\
\text { Chevron Type } \\
\text { Cold Trap }\end{array}$ & $\begin{array}{l}\mathrm{TL} \\
\mathrm{T} \\
\mathrm{B}\end{array}$ & $\begin{array}{ll} & - \\
23, & 20 \\
18,18\end{array}$ & $\begin{array}{l}16, \\
12\end{array}$ & $\begin{array}{c}119,4 \\
7,37 \\
4,3\end{array}$ & io & $\begin{array}{c}- \\
<.1 \\
<.1\end{array}$ & 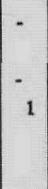 & - & - & $-{ }_{1}$ & $\overline{5}$ & io & 20 & - \\
\hline 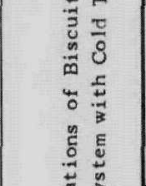 & B-281 & $\begin{array}{l}\text { Biscuit } \\
\text { (Lot } \quad 691 \text { ) } \\
\text { C: } 40-50 \\
\mathrm{~N}: \quad 40 \\
\mathrm{Fe}: \quad 20 \\
\mathrm{Si}: \quad 50\end{array}$ & 303 & $\begin{array}{l}\text { Annealed for } 3 \mathrm{hrs} \text {. } \\
\text { at } 1000^{\circ} \text { Heated to } \mathrm{m} \cdot \mathrm{p} \text {. } \\
\text { in } 8 \mathrm{~min} \text {, Liquated at } 1190^{\circ} \\
\text { for } 5 \mathrm{hrs} \text {; } \\
\text { Directionally solidified. }\end{array}$ & $6 \cdot 10^{-7}$ & Same & c & 22,25 & 35 & - & 10 & $<.1$ & 2 & 5 & 30 & 2 & 5 & 10 & 30 & - \\
\hline 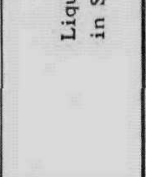 & B-332 & $\begin{array}{l}\text { Biscuit } \\
\text { (Lot } 685 \text { ) } \\
\text { C: } 9-18 \\
\mathrm{~N}: \quad 16-38 \\
\mathrm{Fe}: \quad 50 \\
\mathrm{Si}: \quad 30\end{array}$ & 590 & $\begin{array}{l}\text { Heated to m.p. in } 45 \mathrm{~min} \text {. } \\
\text { Liquated at } 1135^{\circ} \text { for } \\
5 \mathrm{hrs} \text {; Directionally } \\
\text { solidified }\end{array}$ & $\begin{array}{l}\text { From } \\
1 \cdot 10^{-4} \text { max } \\
\text { at m.p. } \\
\text { decreasing } \\
\text { to } 3 \cdot 10^{-7}\end{array}$ & Same & $\begin{array}{l}\mathbf{T} \\
\mathbf{B}\end{array}$ & $\begin{aligned} 14, & 7 \\
9, & 18\end{aligned}$ & $\begin{array}{l}12,11, \\
14\end{array}$ & : & $\begin{array}{l}15 \\
10\end{array}$ & $\begin{array}{l}<.1 \\
<.1\end{array}$ & $\begin{array}{l}2 \\
2\end{array}$ & $\begin{array}{l}2 \\
2\end{array}$ & $\begin{array}{l}70 \\
70\end{array}$ & $\begin{array}{l}2 \\
2\end{array}$ & $\begin{array}{l}2 \\
2\end{array}$ & $\begin{array}{l}20 \\
20\end{array}$ & $\begin{array}{l}20 \\
15\end{array}$ & : \\
\hline
\end{tabular}


Table V

MELTS IN AJAX INDUCTION FURNACE

\begin{tabular}{|c|c|c|c|c|c|c|c|c|c|c|c|c|c|c|c|c|c|c|c|c|c|}
\hline \multirow{3}{*}{ No. } & \multicolumn{3}{|c|}{ Charge } & \multirow{3}{*}{$\begin{array}{l}\text { Furnace } \\
\text { System }\end{array}$} & \multirow{3}{*}{ Crucible } & \multirow{3}{*}{ Melt ing Schedule } & \multirow{3}{*}{$\begin{array}{l}\text { Pressure } \\
\text { mm Hg }\end{array}$} & \multirow{3}{*}{$\begin{array}{l}\text { Sample } \\
\text { Location }\end{array}$} & \multirow{2}{*}{\multicolumn{3}{|c|}{$\begin{array}{c}\text { Chemical Analysis } \\
\text { ppm }\end{array}$}} & \multirow{2}{*}{\multicolumn{10}{|c|}{$\begin{array}{c}\text { Spectrochemical Analys is } \\
\text { ppm }\end{array}$}} \\
\hline & Material & Composition & Weight & & & & & & & & & & & & & & & & & & \\
\hline & & & & & & & & & C & $\mathrm{N}$ & 0. & Al & B & $\mathrm{Cr}$ & $\mathrm{Cu}$ & $\mathrm{Fe}$ & $\mathrm{Mg}$ & Mn & $\mathrm{Ni}$ & $\mathrm{Si}$ & Others \\
\hline B-6 & wet $B-5$ & $\begin{array}{ll}\text { C: } & 570 \\
\text { N: } & 65 \\
\text { Fe: } & 20 \\
\text { Si }: & 20\end{array}$ & 300 & $\begin{array}{l}\text { Ajax Induction with } \\
\text { Forepump }\end{array}$ & MgO & $\begin{array}{l}\text { Heated to } \mathrm{m} . \mathrm{p} . \\
\text { in } 30 \mathrm{~min} \text { at } \\
1275^{\circ} \text { for } 20 \mathrm{~min} ; \\
\text { Cooled to } 1225^{\circ} \\
\text { in } 20 \text { min; Power } \\
\text { of } \mathrm{f} \text {; Furnace } \\
\text { cooled. }\end{array}$ & $\begin{array}{l}\text { decreasing } \\
\text { from } 2 \cdot 10^{-1} \\
\text { to } 7 \cdot 10^{-3}\end{array}$ & $\begin{array}{l}\mathrm{T} \\
\mathrm{B}\end{array}$ & $\begin{array}{r}1100 \\
440\end{array}$ & $\begin{array}{r}925 \\
79\end{array}$ & $\begin{array}{l}12,18 \\
10,48\end{array}$ & $\begin{array}{r}<20 \\
20\end{array}$ & $\begin{array}{r}<.1 \\
.1\end{array}$ & $\begin{array}{l}<_{1} \\
<_{1}\end{array}$ & $\begin{array}{l}<1 \\
<1\end{array}$ & $\begin{array}{l}20 \\
20\end{array}$ & $\begin{array}{r}200 \\
2\end{array}$ & $\begin{array}{l}<.2 \\
<.2\end{array}$ & $\begin{array}{l}<5 \\
<5\end{array}$ & $\begin{array}{l}15 \\
15\end{array}$ & Mo: 60 \\
\hline B-8 & Wed $B-7$ & $\begin{array}{ll}\text { C: } & 600 \\
\text { N: } & 60 \\
\text { Fe: } & 20 \\
\text { Si: } & 15\end{array}$ & 300 & Same & $\mathrm{MgO}$ & $\begin{array}{l}\text { Heated to m.p. } \\
\text { in } 45 \mathrm{~min} \text {; To } \\
1330^{\circ} \text { in } 15 \mathrm{~min} ; \\
\text { Power of } f \\
\text { Furnace cooled. }\end{array}$ & $\begin{array}{l}\text { decreasing } \\
\text { from } 1.4 \cdot 10^{-1} \\
\text { to } 1.0 \cdot 10^{-1}\end{array}$ & $\begin{array}{l}\mathrm{T} \\
\mathrm{B}\end{array}$ & 475 & - & $\begin{array}{r}122,106 \\
18,44\end{array}$ & $<20$ & .1 & $\overline{2}^{2}$ & $\bar{z}_{2}$ & 20 & $<.5$ & .5 & -5 & 20 & Pb: 2 \\
\hline B-77 & Het- B-29 & $\begin{array}{ll}\text { C: } & 440 \\
\text { N: } & 64 \\
\text { Fe: } & 5 \\
\text { Si: } & 30\end{array}$ & 327 & $\begin{array}{l}\text { Ajax Induction; } \\
\text { MB } 100 \text { Booster; } \\
\text { Pump, No } \\
\text { Cold Trap }\end{array}$ & $\mathrm{MgO}$ & $\begin{array}{l}\text { Heated to m.p. } \\
\text { in } 1 \mathrm{hr} ; \mathrm{He} 1 \mathrm{~d} \text { at } \\
1150^{\circ} \text { to } 1200^{\circ} \\
\text { for } 4 \mathrm{hrs} \text {; Power } \\
\text { of } \mathrm{f} \text {; Furnace } \\
\text { cooled. }\end{array}$ & $\begin{array}{l}1.5 \cdot 10^{-2} \\
\max \end{array}$ & $\begin{array}{l}\mathrm{T} \\
\mathrm{B}\end{array}$ & $\begin{array}{l}95 \\
86\end{array}$ & $\begin{array}{l}<10 \\
<10\end{array}$ & $\begin{array}{l}38,18 \\
18,12\end{array}$ & $\begin{array}{l}<20 \\
<20\end{array}$ & $\begin{array}{l}<.1 \\
<.1\end{array}$ & $\begin{array}{l}2 \\
1\end{array}$ & $\begin{array}{l}2 \\
2\end{array}$ & $\begin{array}{l}10 \\
10\end{array}$ & $\begin{array}{r}<.5 \\
5\end{array}$ & $\begin{array}{r}.5 \\
1\end{array}$ & $\begin{array}{l}5 \\
5\end{array}$ & $\begin{array}{l}20 \\
20\end{array}$ & : \\
\hline B-79 & wid. B-28 & $\begin{array}{ll}\text { C: } & 610 \\
\text { N: } & 68 \\
\text { Fe: } & 5 \\
\text { Si: } & 20\end{array}$ & 325 & Same & $\mathrm{MgO}$ & $\begin{array}{l}\text { Heated to m.p. } \\
\text { in } 1 \mathrm{hr} \text {; Held at } \\
\text { about } 1300^{\circ} \text { for } \\
3 \mathrm{hrs;} \text { Power off; } \\
\text { Furnace cooled. }\end{array}$ & $\begin{array}{l}1.5 \cdot 10^{-2} \\
\max \end{array}$ & $\begin{array}{l}\mathrm{T} \\
\mathrm{B}\end{array}$ & $\begin{array}{l}210 \\
188\end{array}$ & $\begin{array}{l}<10 \\
<10\end{array}$ & $\begin{array}{ll}32, & 40 \\
28, & 833\end{array}$ & $\begin{array}{l}<20 \\
<20\end{array}$ & $\begin{array}{l}<.1 \\
<.1\end{array}$ & $\begin{array}{l}5 \\
5\end{array}$ & $\begin{array}{l}2 \\
2\end{array}$ & $\begin{array}{l}15 \\
15\end{array}$ & $\begin{array}{l}<.5 \\
<.5\end{array}$ & $\begin{array}{l}<.2 \\
<.2\end{array}$ & $\begin{array}{l}5 \\
5\end{array}$ & $\begin{array}{l}30 \\
30\end{array}$ & : \\
\hline B-82 & wed B-57 & $\begin{array}{ll}\text { C: } & 450 \\
\text { N: } & 64 \\
\text { Fe: } & 20 \\
\text { Si: } & 10\end{array}$ & 333 & $\begin{array}{l}\text { Ajax Induction; } \\
\text { MCF } 700 \text { Oil-Diff. P. } \\
\text { MB } 100 \text { Booster; } \\
\text { Cold Trap. }\end{array}$ & $\mathrm{UO}_{2}$ & $\begin{array}{l}\text { Heated to m.p. } \\
\text { in } 1 \mathrm{hr} \text {; Heated } \\
\text { to } 1300^{\circ} \text {; Cooled } \\
\text { to m.p.; Raised } \\
\text { for } 10 \text { min to } \\
\text { approx. } 1350^{\circ} \text {. }\end{array}$ & $\begin{array}{l}1 \cdot 10^{-5} \\
\max \end{array}$ & $\begin{array}{l}\mathrm{T} \\
\mathrm{B}\end{array}$ & $\begin{array}{l}38 \mathrm{c} \\
360\end{array}$ & $\begin{array}{l}48 \\
27\end{array}$ & : & $\begin{array}{l}<20 \\
<20\end{array}$ & $\begin{array}{l}<.1 \\
<.1\end{array}$ & $\begin{array}{l}1 \\
1\end{array}$ & $\begin{array}{l}7 \\
7\end{array}$ & $\begin{array}{l}30 \\
30\end{array}$ & $\begin{array}{l}<.5 \\
<.5\end{array}$ & $\begin{array}{l}<.2 \\
<.2\end{array}$ & $\begin{array}{l}<5 \\
<5\end{array}$ & $\begin{array}{l}20 \\
20\end{array}$ & : \\
\hline B-88 & (4) B- 60 & $\begin{array}{ll}\text { C: } & 600 \\
\text { N: } & 58 \\
\text { Fe: } & 20 \\
\text { Si: } & 10\end{array}$ & 348 & Same & $\mathrm{UO}_{2}$ & $\begin{array}{l}\text { Heated to m.p. } \\
\text { in } 3 \mathrm{hrs} \text {; To } \\
1475^{\circ} \text { in } 25 \mathrm{~min} ; \\
\mathrm{He} 1 \mathrm{~d} \text { at } 1150^{\circ} \text { to } \\
1175^{\circ} \text { for } 1 \mathrm{hr} \text {. }\end{array}$ & $\begin{array}{l}10^{-5} \\
\text { decreas ing } \\
\text { to } 10^{-7}\end{array}$ & $\begin{array}{l}\mathrm{T} \\
\mathrm{C} \\
\mathrm{B}\end{array}$ & $\begin{array}{c}- \\
475 \\
-\end{array}$ & $<10^{\circ}-13$ & $\begin{array}{c}75,75 \\
5,-4\end{array}$ & $<20$ & .2 & $\dot{<}$ & $\begin{array}{l}\cdot \\
5 \\
-\end{array}$ & 20 & $<.5$ & $<.2$ & $\begin{array}{l}- \\
<5 \\
-\end{array}$ & is & : \\
\hline
\end{tabular}


:.....

:...: : $\cdots$

...: (...... $\because \cdots$ : $\cdots:$ $\because$

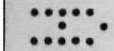
: $\because . .$. : :....: :....:

Table VI

MELTS IN HELIUM AND HYDROGEN ATMOSPHERE IN MAGNESIA CRUCIBLE

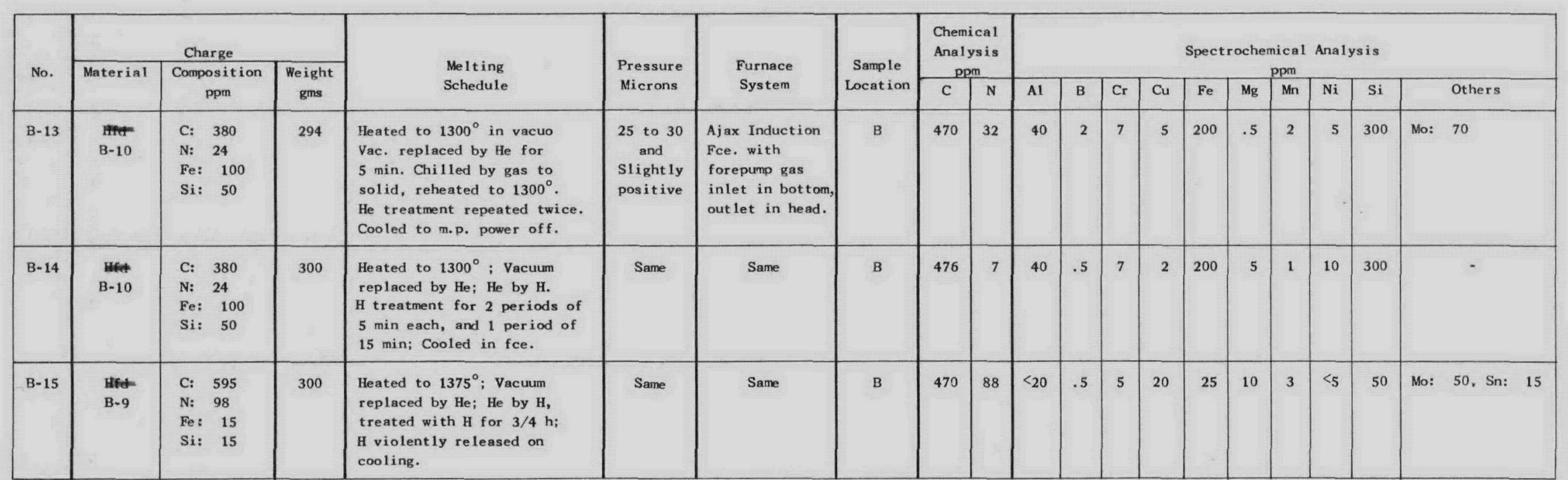


Table VII

MELTS IN VARIOUS CRUCIBLE MATERIALS

\begin{tabular}{|c|c|c|c|c|c|c|c|c|c|c|c|c|c|c|c|c|c|c|c|c|}
\hline \multirow[t]{2}{*}{ No. } & \multirow[t]{2}{*}{ Crucible } & \multicolumn{2}{|c|}{ Charge } & \multirow{2}{*}{$\begin{array}{l}\text { Furnace } \\
\text { System }\end{array}$} & \multirow{2}{*}{$\begin{array}{l}\text { Melting } \\
\text { Conditions }\end{array}$} & \multirow{2}{*}{$\begin{array}{c}\text { Pressure } \\
\text { mm Hg }\end{array}$} & \multirow{2}{*}{$\begin{array}{c}\text { Sample } \\
\text { Locat ion }\end{array}$} & \multicolumn{2}{|c|}{$\begin{array}{c}\text { Chemical } \\
\text { Analys is } \\
\text { ppm }\end{array}$} & \multicolumn{11}{|c|}{$\begin{array}{c}\text { Spectrochemical Analysis } \\
\text { ppm }\end{array}$} \\
\hline & & Material & $\begin{array}{l}\text { We ight } \\
\text { gms }\end{array}$ & & & & & c & $N$ & A1 & B & $\mathrm{Cr}$ & $\mathrm{Cu}$ & $\mathrm{Fe}$ & $\mathrm{Mg}$ & Mn & $\mathrm{Ni}$ & $\mathrm{Si}$ & & hers \\
\hline B-19 & Ta Metal & $\begin{array}{l}\text { Hfd }(B-10) \\
\text { C: } \quad 380 \\
\text { N: } \quad 24 \\
\text { Fe: } \quad 100 \\
\text { Si: } \quad 50\end{array}$ & 1074 & $\begin{array}{l}\text { Globar Res. Fce; } \\
\text { H-2 Oil-Diff. P. } \\
1395 \text { Welch Forep. } \\
\text { Glass Cold Trap. }\end{array}$ & $\begin{array}{l}\text { Heated from m.p. } \\
\text { to } 1265^{\circ} \text { in } \\
2 \mathrm{hrs} \text {; Cooled to } \\
\text { f.p. in } 4 \mathrm{hrs} \text {. }\end{array}$ & $3 \cdot 10^{-3}$ & $\begin{array}{l}\quad \quad \text { T } \\
\text { B near } \\
\text { Crucible } \\
\text { B center }\end{array}$ & $\begin{array}{l}415 \\
240 \\
215\end{array}$ & $\begin{array}{l}<10 \\
<10 \\
<10\end{array}$ & $\begin{array}{l}<20 \\
100 \\
100\end{array}$ & $\begin{array}{l}<.1 \\
<.1 \\
<.1\end{array}$ & $\begin{array}{l}<1 \\
<1 \\
8\end{array}$ & $\begin{array}{l}3 \\
2 \\
5\end{array}$ & $\begin{array}{r}30 \\
100 \\
100\end{array}$ & $\begin{array}{r}<.5 \\
.5 \\
.5\end{array}$ & $\begin{array}{r}<.2 \\
2 \\
2\end{array}$ & $\begin{array}{r}<5 \\
5 \\
5\end{array}$ & $\begin{array}{r}5 \\
200 \\
100\end{array}$ & $\begin{array}{l}\text { Ta: } \\
\text { Ta: } \\
\text { Ta: }\end{array}$ & $\begin{array}{l}>1 \% \\
<.1 \% \\
<.1 \%\end{array}$ \\
\hline B-87 & Alundum & $\begin{array}{ll}\text { Hfd } & (B-58) \\
\text { C: } & 595 \\
\text { N: } & 111 \\
\text { Fe: } & 50 \\
\text { Si: } & 50\end{array}$ & 241 & $\begin{array}{l}\text { Globar Res. Fce; } \\
\text { MCF } 700 \text { Oil-Diff. P. } \\
\text { MB } 100 \text { Booster; } \\
556 \text { Kinney Forep. } \\
\text { No Cold Trap. }\end{array}$ & $\begin{array}{l}\text { Liquated } 48 \mathrm{hrs} \\
\text { at } 1140^{\circ} \text {; } \\
\text { Directiona1ly } \\
\text { solidified. }\end{array}$ & $10^{-5}$ & c & 180 & $<10$ & 200 & $<.1$ & $<_{1}$ & 10 & 15 & $<.5$ & 2 & $<5$ & 20 & & - \\
\hline B-108 & $\mathrm{CaO}$ & $\begin{array}{ll}\text { Hfd } & (B-5-T) \\
\text { C: } & 570 \\
\text { N: } & 65 \\
\text { Fe: } & 20 \\
\text { Si: } & 15\end{array}$ & 58 & $\begin{array}{l}\text { Ajax Induction Fce; } \\
\text { MCF } 700 \text { Oil-Diff. P. } \\
\text { MB } 100 \text { Booster; } \\
1395 \text { Welch Forep. } \\
\text { Pot Cold Trap. }\end{array}$ & $\begin{array}{l}\text { Heated to m.p. } \\
\text { in } 2 \text { hrs; } \\
\text { Crucible broke } \\
\text { when metal was } \\
\text { molten }\end{array}$ & $2 \cdot 10^{-6}$ & & & & & & & & no & ana 1 & zed & & & & \\
\hline B-113 & Zirconia & $\begin{array}{ll}\text { Hfd } & (\mathrm{B}-53) \\
\mathrm{C}: & 590 \\
\mathrm{~N}: & 62 \\
\mathrm{Fe}: & 15 \\
\mathrm{Si}: & 10\end{array}$ & 55 & Same & $\begin{array}{l}\text { Molten } 10 \mathrm{~min} \\
\text { at } 1300^{\circ}\end{array}$ & $2 \cdot 10^{-6}$ & $\begin{array}{l}\text { C } \\
\text { B }\end{array}$ & 460 & $\begin{array}{l}29 \\
-\end{array}$ & $\begin{array}{l}<20 \\
<20\end{array}$ & $\begin{array}{l}.2 \\
.1\end{array}$ & $\begin{array}{r}<1 \\
2\end{array}$ & $\begin{array}{l}2 \\
7\end{array}$ & $\begin{array}{r}5 \\
20\end{array}$ & $\begin{array}{r}.5 \\
1\end{array}$ & $\begin{array}{l}2 \\
2\end{array}$ & $\begin{array}{r}<5 \\
5\end{array}$ & $\begin{array}{r}3 \\
15\end{array}$ & $\begin{array}{l}\mathrm{Zr}: \\
\mathrm{Zr}:\end{array}$ & $\begin{array}{l}80 \\
100\end{array}$ \\
\hline \multirow[t]{2}{*}{ B-153 } & \multirow{2}{*}{$\begin{array}{l}\text { Titanium } \\
\text { Carbide }\end{array}$} & \multirow{2}{*}{$\begin{array}{l}\text { Hi Purity } \\
\text { Electrolyt, } \\
\text { Crystals } \\
(\text { F-6) } \\
\text { C: }>20\end{array}$} & \multirow[t]{2}{*}{80} & \multirow{2}{*}{$\begin{array}{l}\text { Globar Res. Fce. } \\
\text { Same as above }\end{array}$} & \multirow{2}{*}{$\begin{array}{l}\text { Heated to m.p. } \\
\text { in } 1-1 / 2 \mathrm{hrs} \text {; } \\
\text { Heated to } 1250^{\circ} \\
\text { in } 34 \text { min; } \\
\text { Directiona11y } \\
\text { solidified. }\end{array}$} & \multirow[t]{2}{*}{$4.4 \cdot 10^{-5}$} & \multirow{2}{*}{$\begin{array}{l}\quad c \\
\text { pie-shaped } \\
\text { piece } \\
\text { center } \\
\text { piece }\end{array}$} & 170 & 4 & \multirow[t]{2}{*}{$<20$} & \multirow[t]{2}{*}{$<.1$} & \multirow[t]{2}{*}{$<_{1}$} & \multirow[t]{2}{*}{3} & \multirow[t]{2}{*}{30} & \multirow[t]{2}{*}{$<.5$} & \multirow[t]{2}{*}{$<.5$} & \multirow[t]{2}{*}{5} & \multirow[t]{2}{*}{5} & \multirow{2}{*}{\multicolumn{2}{|c|}{ Ti: 500}} \\
\hline & & & & & & & & $\begin{array}{l}\text { O: } \\
\text { o: }\end{array}$ & 26 & & & & & & & & & & & \\
\hline
\end{tabular}



Table IX

MELTS WITH URANIUM NITRIDE IN MAGNESIA CRUCIBLE IN INDUCTION FURNACE

\begin{tabular}{|c|c|c|c|c|c|c|c|c|c|c|c|c|c|c|c|c|c|c|c|c|c|}
\hline \multirow{2}{*}{ Group } & \multirow{2}{*}{ No. } & \multicolumn{3}{|c|}{ Charge } & \multirow{2}{*}{ Me1ting Schedule } & \multirow{2}{*}{$\begin{array}{l}\text { Pressure } \\
\text { Microns }\end{array}$} & \multirow{2}{*}{$\begin{array}{l}\text { Furnace } \\
\text { System }\end{array}$} & \multirow{2}{*}{$\begin{array}{c}\text { Sample } \\
\text { Location }\end{array}$} & \multicolumn{2}{|c|}{$\begin{array}{c}\text { Chemical Analys is } \\
\text { ppm }\end{array}$} & \multicolumn{11}{|c|}{$\begin{array}{c}\text { Spectrochemical Analysis } \\
\text { ppm }\end{array}$} \\
\hline & & Uranium & $\begin{array}{l}\text { Nitride } \\
\text { Addition }\end{array}$ & $\begin{array}{l}\text { Weight } \\
\text { gms }\end{array}$ & & & & & $\begin{array}{l} \\
\end{array}$ & $\mathrm{N}$ & A1 & B & $\mathrm{Cr}$ & $\mathrm{Cu}$ & $\mathrm{Fe}$ & $\mathrm{Mg}$ & Mn & $\mathrm{Ni}$ & $\mathrm{Si}$ & & Others \\
\hline \multirow[t]{2}{*}{$\begin{array}{c}I \\
5 \mathrm{~min} \\
\text { Melts }\end{array}$} & B-41 & $\begin{array}{|ll|}\text { Biscuit } \\
\text { Lot } & 687 \\
\text { C: } & 48-115 \\
\text { N: } & 20 \\
\text { Fe: } & 30 \\
\text { Si: } & 50\end{array}$ & $\begin{array}{l}\mathrm{UN}_{1}, 56 \\
(\mathrm{~B}-32) \\
.1 \% \\
\text { on Bottom } \\
\text { of Crucible }\end{array}$ & 329 & $\begin{array}{l}\text { Molten for } 5 \text { min at } \\
1275^{\circ} \text {; Crucible } \\
\text { cracked }\end{array}$ & $25 \max$ & $\begin{array}{l}\text { Ajax } \\
\text { Induction } \\
\text { MB } 100 \\
\text { Booster } \\
\text { Mechanical } \\
\text { Forepump } \\
\text { No Cold Trap. }\end{array}$ & $\begin{array}{l}\mathrm{T} \\
\mathrm{B}\end{array}$ & $\begin{array}{l}80 \\
75\end{array}$ & $\begin{array}{l}27 \\
46\end{array}$ & $\begin{array}{l}<_{20} \\
<_{20}\end{array}$ & $\begin{array}{r}.5 \\
1\end{array}$ & $\begin{array}{l}<1 \\
<1\end{array} \mid$ & $\begin{array}{l}2 \\
2\end{array}$ & $\begin{array}{l}20 \\
20\end{array}$ & $\begin{array}{l}<.5 \\
<.5\end{array}$ & $\begin{array}{l}1 \\
1\end{array}$ & $\begin{array}{l}15 \\
15\end{array}$ & $\begin{array}{l}20 \\
20\end{array}$ & Mo: & 75, $\mathrm{Pb}: 3$ \\
\hline & $B-36$ & Same & $\begin{array}{l}\mathrm{UN}_{1}, 56 \\
(\mathrm{~B}-32) \\
1 \%\end{array}$ & 338 & $\begin{array}{l}\text { Molten for } 20 \mathrm{~min} \\
\text { at about } 1200^{\circ}\end{array}$ & $5-10$ & Same & $\begin{array}{l}\text { B } \\
\text { BL }\end{array}$ & $\begin{array}{l}95 \\
-\end{array}$ & 40 & $<20$ & $: 3$ & $<_{1}$ & 5 & 20 & $<.5$ &.$^{1}$ & 10 & 15 & & : \\
\hline \multirow{4}{*}{$\begin{array}{c}\text { II } \\
1 / 2 \mathrm{~h} \\
\text { Me1ts }\end{array}$} & B-42 & Same & $\begin{array}{l}\mathrm{UN}_{1} \cdot 56 \\
(\mathrm{~B}-32) \\
.2 \%\end{array}$ & 335 & $\begin{array}{l}\text { Molten for } 1 / 2 \mathrm{~h} \\
\text { at } 1275^{\circ}\end{array}$ & $25 \max$ & Same & $\begin{array}{l}\mathrm{T} \\
\mathrm{B}\end{array}$ & $\begin{array}{l}65 \\
60\end{array}$ & $\begin{array}{l}31 \\
95\end{array}$ & $\begin{array}{l}<20 \\
<20\end{array}$ & $\begin{array}{r}1 \\
.5\end{array}$ & $\begin{array}{l}<_{1} \\
<_{1}\end{array}$ & $\begin{array}{l}2 \\
2\end{array}$ & $\begin{array}{l}20 \\
20\end{array}$ & $\begin{array}{l}<.5 \\
<.5\end{array}$ & $\begin{array}{r}1 \\
.5\end{array}$ & $\begin{array}{l}10 \\
10\end{array}$ & $\begin{array}{l}20 \\
20\end{array}$ & Ag: & $1^{-}$ \\
\hline & B-45 & Same & $\begin{array}{l}\mathrm{UN}_{1}, 66 \\
(\mathrm{~B}-34) \\
1 \%\end{array}$ & 337 & $\begin{array}{l}\text { Molten for } 1 / 2 \mathrm{~h} \\
\text { at } 1275^{\circ}\end{array}$ & $25 \max$ & Same & $\mathrm{T}$ & 75 & $\begin{array}{l}107,18, \\
17,24, \\
6\end{array}$ & $k_{20}$ & .2 & $<1$ & 2 & 20 & $<.5$ & $<.2$ & 5 & 15 & & - \\
\hline & $B-37$ & Same & $\begin{array}{l}\mathrm{UN}_{1}, 56 \\
(\mathrm{~B}-32) \\
2 \%\end{array}$ & 346 & $\begin{array}{l}\text { Molten for } 20 \mathrm{~min} \text { at } \\
1160^{\circ} \text {; Heated in } \\
20 \mathrm{~min} \text { to } 1325^{\circ}\end{array}$ & $25 \max$ & Same & $\begin{array}{l}\mathrm{T} \\
\mathrm{B}\end{array}$ & $\begin{array}{l}45 \\
55\end{array}$ & $\begin{array}{l}352 \\
230\end{array}$ & $\begin{array}{l}<20 \\
<20\end{array}$ & $\begin{array}{l}.5 \\
.3\end{array}$ & $\begin{array}{l}<1 \\
<1\end{array}$ & $\begin{array}{l}2 \\
2\end{array}$ & $\begin{array}{l}20 \\
20\end{array}$ & $\begin{array}{l}<.5 \\
<.5\end{array}$ & $\begin{array}{l}2 \\
1\end{array}$ & $\begin{array}{r}10 \\
5\end{array}$ & $\begin{array}{l}20 \\
20\end{array}$ & Ag: & $\begin{array}{l}1 \\
2, \text { Mo: } 50\end{array}$ \\
\hline & B-48 & Same & $\begin{array}{l}\mathrm{UN}_{1}, 67 \\
(\mathrm{~B}-38) \\
2 \%\end{array}$ & 342 & $\begin{array}{l}\text { Molten for } 25 \mathrm{~min} \\
\text { at } 1300^{\circ}\end{array}$ & $25 \max$ & Same & $\begin{array}{l}\mathrm{T} \\
\mathrm{c}\end{array}$ & $\begin{array}{l}80 \\
26\end{array}$ & \begin{tabular}{|l|}
295,492, \\
$43,13,14$ \\
$54,53,29$ \\
78,85
\end{tabular} & $\begin{array}{l}<20 \\
<20\end{array}$ & $\begin{array}{l}.2 \\
<.1\end{array}$ & $\begin{array}{l}<_{1} \\
<_{1}\end{array}$ & $\begin{array}{l}5 \\
2\end{array}$ & $\begin{array}{l}20 \\
20\end{array}$ & $\begin{array}{r}.5 \\
2\end{array}$ & $\begin{array}{r}.5 \\
2\end{array}$ & $\begin{array}{r}5 \\
10\end{array}$ & $\begin{array}{l}15 \\
20\end{array}$ & & - \\
\hline \multirow{3}{*}{$\begin{array}{l}1 \text { to } 1-1 / 2 \mathrm{~h} \\
\text { Melts }\end{array}$} & $B-51$ & Same & $\begin{array}{l}\mathrm{UN}_{1}, 66 \\
(\mathrm{~B}-35) \\
.5 \%\end{array}$ & 335 & $\begin{array}{l}\text { Molten for } 1 / 2 \mathrm{~h} \text { at } \\
1300^{\circ} \text { and } 1 \mathrm{~h} \text { at } \\
1150^{\circ}\end{array}$ & $25 \max$ & Same & $\mathrm{T}$ & 45 & 120 & $<20$ & 1 & 1 & 2 & 20 & $<.5$ & 2 & 10 & 20 & & - \\
\hline & B- 64 & Same & $\begin{array}{l}\mathrm{UN}_{1} \cdot 66 \\
(\mathrm{~B}-35) \\
.5 \%\end{array}$ & 335 & $\begin{array}{l}\text { Mo1ten for } 1-1 / 2 \mathrm{hrs} \\
\text { at } 1275^{\circ}\end{array}$ & $25 \max$ & Same & $\mathrm{T}$ & 25 & 67 & $<20$ & 1 & 1 & 2 & 20 & $<.5$ & 2 & 10 & 20 & & - \\
\hline & B-47 & Same & $\begin{array}{l}\mathrm{UN}_{1} \cdot 67 \\
(\mathrm{~B}-38) \\
1 \%\end{array}$ & 335 & $\begin{array}{l}\text { Molten for } 1 \mathrm{~h} \text { at } \\
1275^{\circ}\end{array}$ & $25 \max$ & Same & $\mathrm{T}$ & 76 & $76,17,23$ & $<20$ & .5 & $<1$ & 2 & 20 & .5 & 1 & 5 & 20 & & - \\
\hline $\begin{array}{c}\text { IV } \\
2 \mathrm{~h} \\
\text { Melts }\end{array}$ & B-76 & 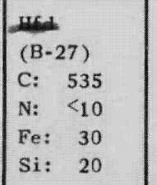 & $\begin{array}{l}\mathrm{UN}_{1} \cdot 70 \\
(\mathrm{~B}-44) \\
.5 \%\end{array}$ & 328 & $\begin{array}{l}\text { Molten for } 2 \mathrm{hrs} \text { at } \\
1275^{\circ}\end{array}$ & $25 \max$ & Same & $\begin{array}{l}\mathrm{T} \\
\mathrm{B}\end{array}$ & $\begin{array}{r}65 \\
150\end{array}$ & $\begin{array}{l}<10 \\
<_{10}\end{array}$ & $\begin{array}{l}20 \\
50\end{array}$ & $\begin{array}{l}.2 \\
.5\end{array}$ & $\begin{array}{l}5 \\
5\end{array}$ & $\begin{array}{l}5 \\
5\end{array}$ & $\begin{array}{l}200 \\
200\end{array}$ & $\begin{array}{l}.5 \\
.5\end{array}$ & $\begin{array}{l}1 \\
1\end{array}$ & $\begin{array}{l}5 \\
5\end{array}$ & $\begin{array}{l}100 \\
100\end{array}$ & & : \\
\hline
\end{tabular}


Table X

MELTS WITH URANIUM NITRIDE IN URANIA CRUCIBLE IN INDUCTION FURNACE

$\therefore \ldots:$

$\vdots \ldots: \therefore$

......

...: :

$\cdots$

$\because \because$

$\because \because$

$\cdots$

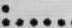

$\therefore$

$\vdots . .$.

$\therefore$

\begin{tabular}{|c|c|c|c|c|c|c|c|c|c|c|c|c|c|c|c|c|c|c|c|}
\hline \multirow{3}{*}{ No. } & \multicolumn{3}{|c|}{ Charge } & \multirow{3}{*}{$\begin{array}{l}\text { Melting } \\
\text { Schedule }\end{array}$} & \multirow{3}{*}{$\begin{array}{l}\text { Pressure } \\
\text { mm Hg }\end{array}$} & \multirow{3}{*}{$\begin{array}{c}\text { Furnace } \\
\text { System }\end{array}$} & \multirow{3}{*}{$\begin{array}{c}\text { Sample } \\
\text { Location }\end{array}$} & \multirow{2}{*}{\multicolumn{2}{|c|}{$\begin{array}{l}\text { Chemical Analys is } \\
\text { ppm }\end{array}$}} & \multirow{2}{*}{\multicolumn{10}{|c|}{$\begin{array}{c}\text { Spectrachemical Analysis } \\
\text { ppm }\end{array}$}} \\
\hline & Uranium & Nitride & $\begin{array}{l}\text { Weight } \\
\text { gms }\end{array}$ & & & & & & & & & & & & & & & & \\
\hline & & Addition & & & & & & C & N & A1 & B & $\mathrm{Cr}$ & $\mathrm{Cu}$ & $\mathrm{Fe}$ & $\mathrm{Mg}$ & Mn & $\mathrm{Ni}$ & $\mathrm{Si}$ & Others \\
\hline B-136 & 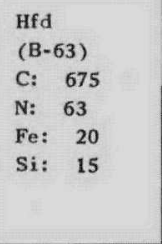 & $\begin{array}{l}\text { UN }_{1} .53 \\
(B-39) \\
1 \% \\
\text { in Bottom } \\
\text { of Crucible }\end{array}$ & 316 & $\begin{array}{l}\text { Molten } 1 / 2 \mathrm{~h} \text { at } \\
1280^{\circ} \text { to } 1325^{\circ}\end{array}$ & $\begin{array}{l}3 \cdot 10^{-5} \\
\text { decreasing } \\
\text { to } 6 \cdot 10^{-6}\end{array}$ & $\begin{array}{l}\text { Ajax Induction } \\
\text { Fce. with } \\
\text { MCF } 700 \text { Oil- } \\
\text { Diff. Pump; } \\
\text { MB } 100 \text { Booster; } \\
\text { We1ch } 1395 \\
\text { Mech. Forepump; } \\
\text { Pot Cold Trap. }\end{array}$ & $\begin{array}{l}\text { T } \\
\text { B }\end{array}$ & $\begin{array}{l}340,345 \\
290\end{array}$ & $\begin{array}{l}17 \\
15\end{array}$ & $\begin{array}{l}10 \\
10\end{array}$ & $\begin{aligned} .1 \\
<.1\end{aligned}$ & $\begin{array}{l}2 \\
2\end{array}$ & $\begin{array}{l}1 \\
1\end{array}$ & $\begin{array}{l}20 \\
20\end{array}$ & $\begin{array}{l}1 \\
1\end{array}$ & $\begin{array}{l}7 \\
7\end{array}$ & $\begin{array}{l}5 \\
5\end{array}$ & $\begin{array}{l}20 \\
20\end{array}$ & : \\
\hline B-139 & 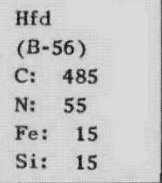 & $\begin{array}{l}\mathrm{UN}_{1} .53 \\
(\mathrm{~B}-39) \\
1 \%\end{array}$ & 305 & $\begin{array}{l}\text { Molten } 3 / 4 \mathrm{~h} \text { at } \\
1280^{\circ} \text { to } 1320^{\circ}\end{array}$ & $6 \cdot 10^{-6}$ & Same & $\begin{array}{l}\mathrm{T} \\
\mathrm{B}\end{array}$ & $\begin{array}{c}270 \\
250,260\end{array}$ & $\begin{array}{l}25 \\
15\end{array}$ & $\begin{array}{l}10 \\
10\end{array}$ & $\begin{array}{l}<.1 \\
<.1\end{array}$ & $\begin{array}{l}2 \\
2\end{array}$ & $\begin{array}{l}1 \\
1\end{array}$ & $\begin{array}{l}20 \\
20\end{array}$ & $\begin{array}{l}1 \\
1\end{array}$ & $\begin{array}{l}3 \\
3\end{array}$ & $\begin{array}{l}5 \\
5\end{array}$ & $\begin{array}{l}20 \\
20\end{array}$ & : \\
\hline B-137 & 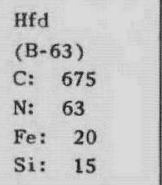 & $\begin{array}{l}\mathrm{UN}_{1} \cdot 53 \\
(\mathrm{~B}-39) \\
1 \%\end{array}$ & 322 & $\begin{array}{l}\text { Molten } 1-1 / 2 \mathrm{hrs} \\
\text { at } 1375^{\circ} \\
\left(1350^{\circ} \text { to } 1400^{\circ}\right)\end{array}$ & $6 \cdot 10^{-6}$ & Same & $\begin{array}{l}\text { T } \\
\text { B }\end{array}$ & $\begin{array}{l}290 \\
300\end{array}$ & $\begin{array}{l}47 \\
25\end{array}$ & $\begin{array}{l}10 \\
10\end{array}$ & $\begin{array}{l}<.1 \\
<.1\end{array}$ & $\begin{array}{l}2 \\
2\end{array}$ & $\begin{array}{l}1 \\
1\end{array}$ & $\begin{array}{l}15 \\
15\end{array}$ & $\begin{array}{l}1 \\
1\end{array}$ & $\begin{array}{l}3 \\
3\end{array}$ & $\begin{array}{l}5 \\
5\end{array}$ & $\begin{array}{l}20 \\
20\end{array}$ & : \\
\hline B-101 & $\begin{array}{l}\text { Hfd } \\
\begin{array}{ll}\text { (B-54) } \\
\text { C: } & 610 \\
\text { N: } & 66 \\
\text { Fe: } & 15 \\
\text { Si: } & 10\end{array}\end{array}$ & $\begin{array}{l}\mathrm{UN}_{1} .53 \\
(\mathrm{~B}-39) \\
.2 \%\end{array}$ & 313 & $\begin{array}{l}\text { Molten } 2 \mathrm{hrs} \text { at } \\
1450^{\circ} \text {; only melt } \\
\text { where al1 nitride } \\
\text { was absorbed by } \\
\text { metal }\end{array}$ & $<1 \cdot 10^{-6}$ & Same & $\begin{array}{l}\text { T } \\
\text { B }\end{array}$ & $\begin{array}{l}235,255 \\
340\end{array}$ & $\begin{array}{l}51 \\
24\end{array}$ & $\begin{array}{l}10 \\
10\end{array}$ & $\begin{array}{l}<.1 \\
<.1\end{array}$ & $\begin{array}{l}2 \\
2\end{array}$ & $\begin{array}{l}1 \\
1\end{array}$ & $\begin{array}{l}30 \\
20\end{array}$ & $\begin{array}{l}1 \\
1\end{array}$ & $\begin{array}{l}.5 \\
.5\end{array}$ & $\begin{array}{l}5 \\
5\end{array}$ & $\begin{array}{l}20 \\
20\end{array}$ & : \\
\hline B-97 & 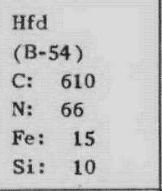 & $\begin{array}{l}\mathrm{UN}_{1}, 53 \\
(\mathrm{~B}-39) \\
1 \%\end{array}$ & 321 & $\begin{array}{l}\text { Molten } 2 \mathrm{hrs} \text { at } \\
1430^{\circ} \text { to } 1450^{\circ}\end{array}$ & 4 to $7 \cdot 10^{-7}$ & Same & $\mathrm{T}$ & 1725 & $\begin{array}{l}115, \\
1590 \\
1760\end{array}$ & $<20$ & $<.1$ & $<1$ & 10 & 20 & .5 & .5 & $<5$ & 30 & - \\
\hline B-92 & 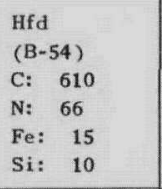 & $\begin{array}{l}\mathrm{UN}_{1}, 74 \\
(\mathrm{~B}-44) \\
1 \%\end{array}$ & 324 & $\begin{array}{l}\text { Molten } 2-1 / 2 \mathrm{hrs} \\
\text { at } 1445^{\circ}\end{array}$ & $<1 \cdot 10^{-6}$ & Same & $\mathrm{T}$ & 500 & $\begin{array}{l}275, \\
100\end{array}$ & $<20$ & .1 & $<_{1}$ & 2 & 10 & $<.5$ & $<.2$ & $<5$ & 5 & - \\
\hline B-111 & $\begin{array}{l}\text { Hi-Purity } \\
\text { Metal pieces } \\
\text { with more } \\
\text { than } 50 \mathrm{ppm} \\
\text { carbon }\end{array}$ & $\begin{array}{l}\mathrm{UN}_{1}, 53 \\
(\mathrm{~B}-39) \\
1 \%\end{array}$ & 243 & $\begin{array}{l}\text { Molten } 2 \mathrm{hrs} \text { at } \\
1440^{\circ} \text { to } 1475^{\circ}\end{array}$ & 4 to $7 \cdot 10^{-7}$ & Same & - & not ana & yzed & & & & & & analyz & & & & \\
\hline
\end{tabular}


Table XI

LIQUATION MELTS IN RESISTANCE FURNACE OF SEPARATELY NITAIDED URANIUM

\begin{tabular}{|c|c|c|c|c|c|c|c|c|c|c|c|c|c|c|c|c|c|c|c|c|c|c|}
\hline \multirow{3}{*}{ Group } & \multirow{3}{*}{ No. } & \multicolumn{3}{|c|}{ Charge } & \multirow{3}{*}{\begin{tabular}{|l} 
Weight \\
gms
\end{tabular}} & \multirow{3}{*}{ Crucible } & \multirow{3}{*}{$\begin{array}{c}\text { Liquation } \\
\text { Schedule }\end{array}$} & \multirow{3}{*}{$\begin{array}{c}\text { Pressure } \\
\mathrm{mm} \mathrm{Hg}\end{array}$} & \multirow{3}{*}{$\begin{array}{l}\text { Furnace } \\
\text { System }\end{array}$} & \multirow{3}{*}{$\begin{array}{c}\text { Sample } \\
\text { Location }\end{array}$} & \multirow{2}{*}{\multicolumn{2}{|c|}{$\begin{array}{c}\text { Chemical Ana lys is } \\
\text { ppm }\end{array}$}} & \multirow{2}{*}{\multicolumn{10}{|c|}{$\begin{array}{c}\text { Spectrochemical Analys is } \\
\text { ppm }\end{array}$}} \\
\hline & & Material & pp & & & & & & & & & & & & & & & & & & & \\
\hline & & & c & $\mathbf{N}$ & & & & & & & & & A1 & B & $\mathrm{C}_{\mathbf{r}}$ & $\mathrm{Cu}$ & $\mathrm{Fe}$ & \begin{tabular}{|l|}
$\mathrm{Mg}$ \\
\end{tabular} & \begin{tabular}{|l|l|}
$M_{n}$ & \\
\end{tabular} & $\mathrm{Ni}$ & $\mathrm{Si}$ & Others \\
\hline 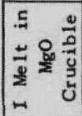 & B-23 & $\begin{array}{l}\text { Hfd melted in } \\
\text { N. Atm. B-18 } \\
\text { (Table VII) }\end{array}$ & 270,310 & 44,76 & 200 & MgO & $\begin{array}{l}\text { Liquated for } 1-1 / 2 \mathrm{hrs} \\
\text { at } 1160^{\circ} ; \text { Cooled to } \\
\text { m.p. in } 3 \mathrm{hrs} \text {. }\end{array}$ & 6 to $3.10^{-5}$ & $\begin{array}{l}\text { Globar Res. Fce; } \\
\text { H-2 Oil-Diff. P. } \\
\text { Cenco Forepump; } \\
\text { Glass Cold Trap }\end{array}$ & $\begin{array}{l}\mathrm{T} \\
\mathrm{B}\end{array}$ & $\begin{array}{l}185 \\
105\end{array}$ & $\begin{array}{l}26 \\
13\end{array}$ & $\begin{array}{l}<20 \\
<20\end{array}$ & $\begin{array}{l}1 \\
1\end{array}$ & $\begin{array}{l}<1 \\
<1\end{array}$ & $\begin{array}{l}3 \\
3\end{array}$ & $\begin{array}{l}10 \\
10\end{array}$ & $\begin{array}{l}<.5 \\
<.5\end{array}$ & \begin{tabular}{r|}
.5 \\
2
\end{tabular} & $\begin{array}{l}<5 \\
<5\end{array}$ & $\begin{array}{l}20 \\
20\end{array}$ & : \\
\hline \multirow{6}{*}{ 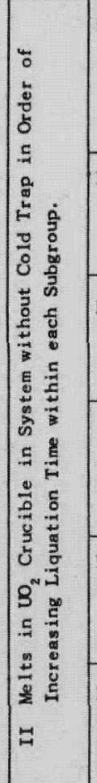 } & B-65 & $\begin{array}{l}\text { Nitrided Biscuit } \\
\text { B-47 (Table VIII) } \\
\text { Nitride Layer } \\
\text { removed }\end{array}$ & 76 & $\begin{array}{c}76,17, \\
23\end{array}$ & 230 & $\mathrm{UO}_{2}$ & $\begin{array}{l}\text { Heated from m.p. to } \\
1200^{\circ} \text { in } 1-1 / 2 \mathrm{hrs} \text {; } \\
\text { Liquated for } 4-1 / 2 \mathrm{hrs} \\
\text { at } 1170^{\circ} \text { Cooled at a } \\
\text { tate of } 4^{\circ} \mathrm{C} / \mathrm{min}\end{array}$ & $1.3 .10^{-5}$ & $\begin{array}{l}\text { Globar Res. Fce; } \\
\text { MCF } 700 \text { Oi1-Diff. P. } \\
\text { MB } 100 \text { Booster; } \\
556 \text { Kinney Forep. } \\
\text { No Cold Trap }\end{array}$ & c & 32 & 44,51 & $<20$ & .1 & $<1$ & 2 & 20 & 1 & .5 & 10 & 20 & - \\
\hline & B-75 & $\begin{array}{l}\text { Nitrided Biscuit } \\
\text { B-51 (Table VIII) } \\
\text { Nitride Layer } \\
\text { removed. }\end{array}$ & 45 & 120 & 212 & $\mathrm{UO}_{2}$ & $\begin{array}{l}\text { Liquated for } 9-1 / 2 \mathrm{hrs} \\
\text { at } 1190^{\circ} \mathrm{C} ; \\
\text { Directionally } \\
\text { solidified }\end{array}$ & $1.3 .10^{-5}$ & Same & c & 40 & 130,114 & $<20$ & $<.1$ & $<1$ & 1 & 10 & $<.5$ & $<.2$ & 10 & 20 & - \\
\hline & B-78 & \begin{tabular}{|l} 
Nitrided Biscuit \\
B-48 (Table VIII) \\
Nitride Layer \\
removed
\end{tabular} & 80 & $\begin{array}{cc}295, & 492 \\
43, & 13 \\
14 & \end{array}$ & 193 & $\mathrm{wO}_{2}$ & $\begin{array}{l}\text { Liquated for } 15 \mathrm{hrs} \\
\text { at } 1190^{\circ} \text {; } \\
\text { Directionally } \\
\text { sol idified }\end{array}$ & $1.3 .10^{-5}$ & Same & c & 14,15 & $<10$ & $<20$ & .2 & 1 & 7 & 20 & .5 & .2 & 5 & 30 & - \\
\hline & B-80 & $\begin{array}{l}\text { Nitrided Biscuit } \\
\text { B-45 (Table vIII) } \\
\text { Nitride Layer on } \\
\text { bottom of ingot }\end{array}$ & 75 & $\begin{array}{l}107,18 \\
17,24, \\
6\end{array}$ & 255 & $\mathrm{UO}_{2}$ & $\begin{array}{l}\text { Liquated for } 44 \mathrm{hrs} \\
\text { at } 1190^{\circ} \text {; } \\
\text { Directionally } \\
\text { solidified }\end{array}$ & $\begin{array}{l}\text { erratic } \\
1.3 .10^{-5}\end{array}$ & Same & c & $\begin{array}{l}14,10, \\
12\end{array}$ & $<10$ & $<20$ & $<.1$ & 2 & 2 & 15 & $<.5$ & $<.2$ & 10 & 30 & - \\
\hline & B-134 & $\begin{array}{l}\text { Nitrided Hfd } \\
\text { B-97 (Table IX) } \\
\text { Nitride Layer on } \\
\text { bot tom of ingot }\end{array}$ & $\begin{array}{l}1725 \\
\text { (Aver age } \\
\text { probably } \\
\text { less) }\end{array}$ & $\begin{array}{r}115 \\
1590 \\
1760\end{array}$ & 235 & $\mathrm{UO}_{2}$ & $\begin{array}{l}\text { Liquated for } 24 \mathrm{hrs} \\
\text { at } 1190^{\circ} \text {; } \\
\text { Directionally } \\
\text { solidified }\end{array}$ & $\begin{array}{l}1.10^{-5} \text { to } \\
6.10^{-6}\end{array}$ & Same & $\begin{array}{l}\mathrm{T} \\
\mathrm{B}\end{array}$ & $\begin{array}{l}200,205 \\
190,195\end{array}$ & $\begin{array}{r}11 \\
<10\end{array}$ & $\begin{array}{l}10 \\
10\end{array}$ & $\begin{array}{l}.1 \\
.1 \\
\end{array}$ & $\begin{array}{l}2 \\
2\end{array}$ & $\begin{array}{l}1 \\
1\end{array}$ & $\begin{array}{l}30 \\
30\end{array}$ & $\begin{array}{l}1 \\
1\end{array}$ & $\begin{array}{l}.5 \\
.5\end{array}$ & 5 & $\begin{array}{l}20 \\
20\end{array}$ & : \\
\hline & B-98 & $\begin{array}{l}\text { Nitrided Hfd } \\
\text { B-92 (Table IX) } \\
\text { Nitride Layer on } \\
\text { bottom of ingot }\end{array}$ & 500 & $\begin{array}{l}275, \\
100\end{array}$ & 217 & $\mathrm{WO}_{2}$ & $\begin{array}{l}\text { Liquated for } 68 \mathrm{hrs} \\
\text { at } 1190^{\circ} \text {; } \\
\text { Directionally } \\
\text { solidified }\end{array}$ & $\begin{array}{l}1.10^{-5} \text { to } \\
6.10^{-6}\end{array}$ & Same & $\begin{array}{l}\text { T } \\
\text { B }\end{array}$ & $\begin{array}{l}135,130 \\
120\end{array}$ & $\begin{array}{r}15 \\
<10\end{array}$ & $\begin{array}{l}10 \\
10\end{array}$ & $<.1$ & $\begin{array}{l}2 \\
2\end{array}$ & $\begin{array}{l}1 \\
1\end{array}$ & $\begin{array}{l}30 \\
20\end{array}$ & $\begin{array}{l}1 \\
1\end{array}$ & $\begin{array}{r}.5 \\
.5\end{array}$ & $\begin{array}{l}5 \\
5\end{array}$ & $\begin{array}{l}30 \\
20\end{array}$ & : \\
\hline
\end{tabular}


Table XII

$\therefore . . .:$ :

$\therefore:$

.....

....:.:

......

$\because \because$ :

$\because \because$

$\because \because \cdots$

$\vdots \ldots$

$\therefore \ldots$

$\therefore$

$\ldots$

:.....:

ONE STEP NITRIDING AND LIQUATION MELTS IN URANIA CRUCIBLE IN RESISTANCE FURNACE

\begin{tabular}{|c|c|c|c|c|c|c|c|c|c|c|c|c|c|c|c|c|c|c|c|}
\hline \multirow{3}{*}{ No. } & \multicolumn{3}{|c|}{ Charge } & \multirow{3}{*}{$\begin{array}{l}\text { Liquation } \\
\text { Schedule }\end{array}$} & \multirow{3}{*}{$\begin{array}{l}\text { Pressure } \\
\text { mm Hg }\end{array}$} & \multirow{3}{*}{$\begin{array}{l}\text { Furnace } \\
\text { System }\end{array}$} & \multirow{3}{*}{$\begin{array}{c}\text { Sample } \\
\text { Locat ion }\end{array}$} & \multirow{2}{*}{\multicolumn{2}{|c|}{$\begin{array}{c}\text { Chemical Analysis } \\
\text { ppm }\end{array}$}} & \multirow{2}{*}{\multicolumn{10}{|c|}{$\begin{array}{l}\text { Spect rochemical Analys is } \\
\text { ppm }\end{array}$}} \\
\hline & Ur anium & Nitride & Weight & & & & & & & & & & & & & & & & \\
\hline & & & & & & & & C & $\mathrm{N}$ & Al & B & $\mathrm{Cr}$ & $\mathrm{Cu}$ & $\mathrm{Fe}$ & $\mathrm{Mg}$ & Nin & $\mathrm{Ni}$ & $\mathrm{Si}$ & Others \\
\hline B-81 & $\begin{array}{l}\text { Hfd } \\
(\text { B-28) } \\
\text { C: } \quad 610 \\
\text { N: } \quad 68 \\
\text { Fe: } \quad 5 \\
\text { Si: } \quad 20\end{array}$ & $\begin{array}{l}\mathrm{UN}_{1}, 74 \\
(\mathrm{~B}-44) \\
1 / 2 \% \\
\text { in bottom } \\
\text { of crucible }\end{array}$ & 201 & $\begin{array}{l}\text { Liquated } 35 \mathrm{hrs} \text { at } 1150^{\circ} \text {; } \\
\text { Directionally solidified; } \\
\text { Reliquated } 36 \mathrm{hrs} \text { at } \\
1150^{\circ} \text {; Directionally } \\
\text { solidified }\end{array}$ & $1.3 \cdot 10^{-5}$ & $\begin{array}{l}\text { Globar Res. Fce; } \\
\text { MCF } 700 \text { Oil-Diff. P. } \\
\text { MB } 100 \text { Booster } \\
556 \text { Kinney Forep. } \\
\text { No Cold Trap }\end{array}$ & c & 225 & 36,14 & $<20$ & .1 & 2 & 3 & 50 & $<.5$ & .5 & $<5$ & 30 & - \\
\hline B- 85 & $\begin{array}{l}\text { Hfd } \\
\text { (B-58) } \\
\text { C: } \quad 595 \\
\text { N: } \quad 111 \\
\text { Fe: } \quad 50 \\
\text { Si: } \quad 50 \\
\end{array}$ & $\begin{array}{l}\mathrm{UN}_{1}, 74 \\
(\mathrm{~B}-44) \\
1 \% \\
\text { in bottom } \\
\text { of crucible }\end{array}$ & 267 & $\begin{array}{l}\text { Heated in } 12 \mathrm{hrs} \text { to } \\
1300^{\circ} \text {; Liquated } 60 \mathrm{hrs} \\
\text { at } 1300^{\circ} \text {; Directionally } \\
\text { solidified }\end{array}$ & $<1 \cdot 10^{-5}$ & Same & $\begin{array}{l}\mathrm{T} \\
\mathrm{B}\end{array}$ & $\begin{array}{l}238, \\
205,165\end{array}$ & $\begin{array}{r}<10 \\
15\end{array}$ & $\begin{array}{l}10 \\
10\end{array}$ & 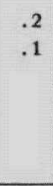 & $\begin{array}{l}2 \\
2\end{array}$ & $\begin{array}{l}1 \\
1\end{array}$ & $\begin{array}{l}50 \\
50\end{array}$ & $\begin{array}{l}1 \\
1\end{array}$ & $\begin{array}{l}2 \\
2\end{array}$ & $\begin{array}{l}5 \\
5\end{array}$ & $\begin{array}{l}20 \\
30\end{array}$ & : \\
\hline B-241 & $\begin{array}{l}\text { Biscuit } \\
\text { Lot } \quad 691 \\
\text { C: } \quad 40-50 \\
\text { N: } \quad 40 \\
\text { Fe: } \quad 20 \\
\text { Si: } \quad 50\end{array}$ & $\begin{array}{l}\mathrm{UN}_{1}, 0 \\
\text { in we11 } \\
\text { ins ide } \\
\text { uranium } \\
\text { near bot tom }\end{array}$ & 283 & $\begin{array}{l}\text { Heated in } 1 \mathrm{~h} \text { to } \mathrm{m} . \mathrm{p} \text {. } \\
\text { Overheated to } 1300^{\circ} \\
\text { for } 1 \mathrm{~h} \text {; Liquated for } \\
5 \mathrm{hrs} \text { at } 1190^{\circ} \\
\text { Directionally } \\
\text { solidified }\end{array}$ & $\begin{array}{l}5 \cdot 10^{-6} \text { to } \\
3 \cdot 10^{-7}\end{array}$ & $\begin{array}{l}\text { Globar Res. Fce; } \\
\text { MCF } 700 \text { Oil-Diff. P. } \\
\text { MB } 200 \text { Booster } \\
556 \text { Kinney Forep. } \\
\text { Chevron Type } \\
\text { Cold Trap. }\end{array}$ & $\begin{array}{l}\text { T } \\
\text { B }\end{array}$ & $\begin{array}{l}25,27 \\
26,29\end{array}$ & $\begin{array}{l}15 \\
50\end{array}$ & $\begin{array}{l}10 \\
10\end{array}$ & $<.11$ & $\begin{array}{l}2 \\
2\end{array}$ & $\begin{array}{l}1 \\
1\end{array}$ & $\begin{array}{l}15 \\
20\end{array}$ & $\begin{array}{l}1 \\
1\end{array}$ & $\begin{array}{l}3 \\
3\end{array}$ & $\begin{array}{r}5 \\
10\end{array}$ & $\begin{array}{l}20 \\
30\end{array}$ & $\dot{-}$ \\
\hline
\end{tabular}




\begin{tabular}{|c|c|c|c|c|c|c|c|c|c|c|c|c|c|c|c|c|c|c|c|c|c|}
\hline \multirow[b]{2}{*}{ No. } & \multicolumn{4}{|c|}{ Charge } & \multirow{2}{*}{$\begin{array}{l}\text { Liquation } \\
\text { Schedule }\end{array}$} & \multirow{2}{*}{$\begin{array}{c}\text { Pressure } \\
\text { mm Hg }\end{array}$} & \multirow{2}{*}{$\begin{array}{c}\text { Furnace } \\
\text { System }\end{array}$} & \multirow{2}{*}{$\begin{array}{l}\text { Sample } \\
\text { Location }\end{array}$} & \multicolumn{2}{|c|}{$\begin{array}{c}\text { Chemical } \\
\text { Analys is } \\
\text { ppm }\end{array}$} & \multirow{2}{*}{\multicolumn{11}{|c|}{$\begin{array}{c}\text { Spectrochemical Analysis } \\
\mathrm{ppm}\end{array}$}} \\
\hline & Uranium & $\begin{array}{l}\text { Nitride } \\
\text { Addition }\end{array}$ & Crucible & $\begin{array}{c}\text { We ight } \\
\text { gms }\end{array}$ & & & & & & & & & & & & & & & & & Others \\
\hline B-166 & $\begin{array}{l}\text { Biscuit } \\
\text { (Lot } 691 \text { ) } \\
\text { C: } 40-50 \\
\text { N: } 40 \\
\text { Fe: } 20 \\
\text { Si: } \quad 50\end{array}$ & $\begin{array}{l}\mathrm{UN}_{1}, 53 \\
(\mathrm{~B}-39) \\
1 \% \\
\text { in bottom } \\
\text { of crucible }\end{array}$ & $.1 \%$ & 109 & $\begin{array}{l}\text { Heated to m.p. in } 2 \mathrm{hrs} \text {; } \\
\text { Liquated for } 3 \mathrm{hrs} \text { at } \\
1185^{\circ} \mathrm{C} \text {; Directionally } \\
\text { solidified }\end{array}$ & $\begin{array}{l}10^{-5} \text { to } \\
10^{-6} \\
\text { erratic }\end{array}$ & $\begin{array}{l}\text { Globar Res. Furnace } \\
\text { MCF } 700 \text { Oil-Diff. P. } \\
\text { MB } 100 \text { Booster } \\
556 \text { Kinney Forep. } \\
\text { No Cold Trap }\end{array}$ & c & 45 & 15 & 20 & $<.1$ & $<1$ & 5 & 20 & 1 & 5 & 5 & 50 & & - \\
\hline B-248 & $\begin{array}{l}\text { Biscuit } \\
\text { (Lot } 691 \text { ) } \\
\text { C: } 40-50 \\
\text { N: } 40 \\
\text { Fe: } \quad 20 \\
\text { Si: } \quad 50\end{array}$ & $\begin{array}{l}\mathrm{UN}_{1},{ }^{\circ} \\
1 / 2 \% \\
\text { in we11 } \\
\text { inside meta1 } \\
\text { near bottom }\end{array}$ & $.1 \%$ & 188 & $\begin{array}{l}\text { Heated to m.p. in } 50 \text { min; } \\
\text { Liquated for } 5 \text { hrs at } \\
1185^{\circ} \text {; Directionally } \\
\text { solidif ied }\end{array}$ & $\begin{array}{l}3 \cdot 10^{-5} \\
\text { to } 5 \cdot 10^{-7}\end{array}$ & $\begin{array}{l}\text { Globar Res. Furnace } \\
\text { MCF } 700 \text { Oil-Diff. P. } \\
\text { MB } 200 \text { Booster } \\
556 \text { Kinney Forep. } \\
\text { Chevron Type Cold Trap }\end{array}$ & $\begin{array}{l}\mathrm{T} \\
\mathrm{B}\end{array}$ & $\begin{array}{l}21 \\
20\end{array}$ & $\begin{array}{r}8 \\
22\end{array}$ & $\begin{array}{l}10 \\
10\end{array}$ & $\begin{array}{l}<.1 \\
<.1\end{array}$ & $\begin{array}{l}1 \\
1\end{array}$ & $\begin{array}{l}3 \\
3\end{array}$ & $\begin{array}{l}30 \\
30\end{array}$ & $\begin{array}{l}<.5 \\
<.5\end{array}$ & $\begin{array}{l}5 \\
5\end{array}$ & $\begin{array}{l}15 \\
10\end{array}$ & $\begin{array}{l}20 \\
20\end{array}$ & Ag: & $\begin{array}{l}\text { 1. } \mathrm{Pb}: \\
1\end{array}$ \\
\hline B-231 & $\begin{array}{l}\text { Hfd } \\
\text { (B-61) } \\
\text { C: } \quad 570 \\
\text { N: } \quad 80 \\
\text { Fe: } \quad 20 \\
\text { Si: } \quad 10\end{array}$ & $\begin{array}{l}\mathrm{UN}_{1} \text {. } \\
1 \% \text { total } \\
.7 \% \text { in we } 11 \\
\text { Inside metal } \\
\text { near bottom } \\
.3 \% \text { in bottom } \\
\text { of crucible }\end{array}$ & $.1 \%$ & 298 & $\begin{array}{l}\text { Heated to m. p. in } 50 \mathrm{~min} \text {; } \\
\text { Overheated for } 1 \mathrm{hr} \text { at } \\
1300^{\circ} \text {; Liquated for } \\
5 \mathrm{hrs} \text { at } 1185^{\circ} \text {; } \\
\text { Directionally solidified }\end{array}$ & $\begin{array}{l}2 \cdot 10^{-5} \\
\text { to } 4 \cdot 10^{-7}\end{array}$ & Same & $\begin{array}{l}\mathrm{T} \\
\mathrm{B}\end{array}$ & $\begin{array}{l}265 \\
240\end{array}$ & $\begin{array}{l}<10 \\
<10\end{array}$ & $\begin{array}{l}<20 \\
<20\end{array}$ & $\begin{array}{l}.1 \\
.1\end{array}$ & $\begin{array}{l}1 \\
1\end{array}$ & $\begin{array}{r}10 \\
5\end{array}$ & $\begin{array}{l}15 \\
15\end{array}$ & $\begin{array}{r}<.5 \\
.8\end{array}$ & $\begin{array}{l}2 \\
3\end{array}$ & $\begin{array}{l}5 \\
5\end{array}$ & $\begin{array}{l}50 \\
50\end{array}$ & & : \\
\hline B-252 & $\begin{array}{l}\text { Biscuit } \\
\text { (Lot } 691 \text { ) } \\
\text { C: } 40-50 \\
\text { N: } 40 \\
\text { Fe: } \quad 20 \\
\text { Si: } \quad 50\end{array}$ & $\begin{array}{l}\mathrm{UN}_{1},{ }^{\circ} \\
.35 \% \\
\text { in we } 11 \\
\text { inside metal } \\
\text { near bottom }\end{array}$ & $.1 \%$ & 281 & $\begin{array}{l}\text { Heated to m.p. in } 50 \mathrm{~min} \text {; } \\
\text { Liquated at } 1185^{\circ} \text { for } \\
22 \text { hrs; Direct ionally } \\
\text { solidified }\end{array}$ & $\begin{array}{l}3 \cdot 10^{-5} \\
\text { to } 3 \cdot 10^{-7}\end{array}$ & Same & $\begin{array}{l}\mathrm{T} \\
\mathrm{B}\end{array}$ & $\begin{array}{l}22 \\
24\end{array}$ & $\begin{array}{l}16 \\
20\end{array}$ & $\begin{array}{l}50 \\
10\end{array}$ & 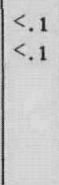 & $\begin{array}{l}1 \\
1\end{array}$ & $\begin{array}{l}3 \\
3\end{array}$ & $\begin{array}{l}30 \\
30\end{array}$ & $\begin{array}{l}<.5 \\
<.5\end{array}$ & $\begin{array}{l}5 \\
5\end{array}$ & $\begin{array}{l}15 \\
10\end{array}$ & $\begin{array}{l}30 \\
20\end{array}$ & & : \\
\hline
\end{tabular}


…..:

\begin{tabular}{|c|c|c|c|c|c|c|c|c|c|c|c|c|c|c|c|c|c|c|c|c|c|c|}
\hline \multirow{2}{*}{ No. } & \multicolumn{3}{|c|}{ Charge } & \multirow{2}{*}{$\begin{array}{c}\text { Liquation } \\
\text { Schedule }\end{array}$} & \multirow{2}{*}{$\begin{array}{l}\text { Furnace } \\
\text { System }\end{array}$} & \multirow{2}{*}{$\begin{array}{c}\text { Pressure } \\
\text { mm Hg }\end{array}$} & \multirow{2}{*}{$\begin{array}{c}\text { Sample } \\
\text { Location }\end{array}$} & \multicolumn{3}{|c|}{$\begin{array}{l}\text { Chemical Ana lys is } \\
\text { Ppm }\end{array}$} & \multicolumn{12}{|c|}{$\begin{array}{l}\text { Spectrochemical Analys is } \\
\text { ppm }\end{array}$} \\
\hline & 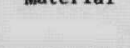 & Addition & $\mathrm{gms}$ & & & & & c & N & 0 & Al & $B$ & $\mathrm{Cr}$ & $\mathrm{Cu}$ & $\mathrm{Fe}$ & $\mathrm{Mg}$ & Mn & \begin{tabular}{|l|l}
$\mathrm{Ni}$ \\
\end{tabular} & Si & $\mathrm{Ta}$ & $T i$ & $2 x$ \\
\hline B-99 & $\begin{array}{l}\text { Hfd } \\
\text { (B-26) } \\
\text { C: } \quad 385 \\
\text { N: } \quad 75 \\
\text { Fe: } \quad 5 \\
\text { Si: } \quad 10\end{array}$ & $\begin{array}{l}\text {.12\% } \\
\text { Ta sheet } \\
\text { in bottom } \\
\text { of crucible }\end{array}$ & 289 & $\begin{array}{l}\text { Liquated for } \\
15 \text { hrs at } 1190^{\circ} \\
\text { Directionally } \\
\text { solidified }\end{array}$ & $\begin{array}{l}\text { Globar Res. Fce; } \\
\text { NCF } 700 \text { Oil-Diff. P. } \\
\text { MB } 100 \text { Booster } \\
556 \text { Kinney Forep. } \\
\text { No Cold Trap }\end{array}$ & $\begin{array}{l}10^{-5} \text { to } \\
10^{-6}\end{array}$ & $\begin{array}{l}\mathrm{T} \\
\mathrm{B} \\
\mathrm{BO} \\
\mathrm{BC}\end{array}$ & $\begin{array}{c}230 \\
200 \\
\vdots\end{array}$ & $\begin{array}{r}12 \\
8 \\
- \\
-\end{array}$ & ${ }_{400,}^{\vdots}{ }_{6}^{196}$ & $\begin{array}{l}8 \\
8 \\
-\end{array}$ & $\begin{array}{l}.1 \\
: \\
:\end{array}$ & $\begin{array}{l}1 \\
1 \\
\vdots \\
\end{array}$ & $\begin{array}{r}15 \\
8 \\
: \\
.\end{array}$ & $\begin{array}{c}20 \\
20 \\
\vdots \\
-\end{array}$ & $\begin{array}{r}<1 \\
<1 \\
< \\
:\end{array}$ & $\begin{array}{l}4 \\
2 \\
\vdots\end{array}$ & $\begin{array}{l}2 \\
8 \\
\vdots \\
:\end{array}$ & $\begin{array}{l}10 \\
10 \\
:\end{array}$ & $\begin{array}{c}200 \\
200 \\
:\end{array}$ & : & $\vdots$ \\
\hline B-115 & $\begin{array}{l}\text { Biscuit } \\
\text { (Lot } 687 \text { ) } \\
\text { C: } 48-115 \\
\text { N: } 20 \\
\text { Fe: } \quad 30 \\
\text { Si: } \quad 50 \\
\end{array}$ & $\begin{array}{l}.1 \% \\
\text { Ta sheet } \\
\text { in bottom } \\
\text { of crucible }\end{array}$ & 220 & $\begin{array}{l}\text { Liquated for, } \\
20 \text { hrs at } 1190^{\circ} \\
\text { Directionally } \\
\text { solidified }\end{array}$ & Same & $\begin{array}{l}10^{-5} \\
10^{-6}\end{array}$ to & c & 59,51 & 53 & - & $<20$ & $<.1$ & $<1$ & 5 & 20 & $<.5$ & .5 & 10 & 20 & 120 & - & - \\
\hline B-120 & Same & $\begin{array}{l}.09 \% \\
\mathrm{Ti} \\
\text { in bottom } \\
\text { of crucible }\end{array}$ & 151 & $\begin{array}{l}\text { Liquated for } \\
24 \mathrm{hrs} \text { at } 1290^{\circ}\end{array}$ & Same & $3 \cdot 10^{-6}$ & $\begin{array}{l}\mathrm{T} \\
\mathrm{C} \\
\mathrm{B}\end{array}$ & $\begin{array}{l}36 \\
59\end{array}$ & 11 & $\begin{array}{c}7,5 \\
\vdots\end{array}$ & $\begin{array}{l}20 \\
\dot{20}\end{array}$ & $\begin{array}{l}<.1 \\
<.1\end{array}$ & 1 & $\begin{array}{l}2 \\
2 \\
2\end{array}$ & $\begin{array}{l}10 \\
15 \\
15\end{array}$ & $\begin{array}{l}.5 \\
1\end{array}$ & $\begin{array}{l}<.2 \\
.2\end{array}$ & $\begin{array}{l}10 \\
\dot{10}\end{array}$ & $\begin{array}{l}10 \\
10\end{array}$ & $\vdots$ & $\begin{array}{c}800 \\
\dot{700}\end{array}$ & : \\
\hline B-103 & 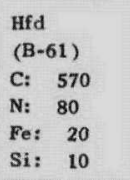 & $\begin{array}{l}.1 \% \\
\mathrm{z}_{\mathrm{r}} \text { turnings } \\
\text { in bottom } \\
\text { of crucible }\end{array}$ & 252 & $\begin{array}{l}\text { Liquated for } \\
24 \mathrm{hrs} \text { at } 1190^{\circ}\end{array}$ & Same & $4 \cdot 10^{-5}$ & $\begin{array}{l}\mathrm{T} \\
\mathrm{C} \\
\mathrm{B}\end{array}$ & $\begin{array}{c}145 \\
\dot{0} \\
205\end{array}$ & $\begin{array}{r}8 \\
- \\
10\end{array}$ & 2,4 & $\begin{array}{l}<20 \\
<20\end{array}$ & $\begin{array}{l}<.1 \\
.2 \\
.2\end{array}$ & $\stackrel{2}{2}$ & $\begin{array}{l}5 \\
2 \\
2\end{array}$ & $\begin{array}{c}20 \\
20 \\
20\end{array}$ & $\begin{array}{l}<.5 \\
.5\end{array}$ & $\begin{array}{l}<.5 \\
<.5\end{array}$ & $\begin{array}{l}5 \\
5\end{array}$ & $\begin{array}{l}10 \\
20\end{array}$ & $\vdots$ & $\vdots$ & $\begin{array}{r}175 \\
100\end{array}$ \\
\hline
\end{tabular}

MELTS IN URANIA CRUCIBLE WITH ADDITIONS OF TANTALUM, TITANIUM, OR ZIRCONIUM 
MELTS IN URANIA CRUCIBLE STIRRED WITH TANTALUM ROD

\begin{tabular}{|c|c|c|c|c|c|c|c|c|c|c|c|c|c|c|c|c|c|c|c|c|c|}
\hline \multirow[b]{2}{*}{ No. } & \multicolumn{2}{|l|}{ Charge } & \multirow{2}{*}{$\begin{array}{l}\text { Furnace } \\
\text { System }\end{array}$} & \multicolumn{2}{|c|}{ Stirring } & \multirow{2}{*}{$\begin{array}{c}\text { Pressure } \\
\mathrm{mm} \mathrm{Hg}\end{array}$} & \multirow{2}{*}{$\begin{array}{c}\text { Sample } \\
\text { Location }\end{array}$} & \multirow{2}{*}{\multicolumn{3}{|c|}{$\begin{array}{c}\text { Chemical Analys is } \\
\text { ppm }\end{array}$}} & \multirow{2}{*}{\multicolumn{11}{|c|}{$\begin{array}{l}\text { Spectrochemical Analys is } \\
\text { ppm }\end{array}$}} \\
\hline & Material & $\begin{array}{c}\text { Weight } \\
\text { gms }\end{array}$ & & $\begin{array}{c}\text { Temperature } \\
{ }^{\circ} \mathrm{C}\end{array}$ & \begin{tabular}{|l|} 
Time \\
\end{tabular} & & & & & & & & & & & & & & & & \\
\hline B-141 & $\begin{array}{l}\text { Biscuit } \\
\text { (Lot } 687 \text { ) } \\
\text { C: } \quad 48-115 \\
\mathrm{~N}: \quad 20 \\
\mathrm{Fe}: \quad 30 \\
\mathrm{Si}: \quad 50\end{array}$ & 142 & $\begin{array}{l}\text { Ajax Induction Fce. } \\
\text { MCF } 700 \text { Oil-Diff. P. } \\
\text { MB } 100 \text { Booster } \\
1395 \text { We Ich Forep. } \\
\text { Pot Cold Trap }\end{array}$ & 1150 & 1 & $2 \cdot 10^{-6}$ & $\begin{array}{l}\mathrm{C} \\
\mathrm{C}\end{array}$ & $\begin{array}{c}78, \quad 70 \\
90,99 \\
-\end{array}$ & 13 & 25,11 & $<20$ & - & $\begin{array}{l}<1 \\
-\end{array}$ & . & 20 & $\begin{array}{l}5 \\
.\end{array}$ & - & - & . & $\begin{array}{c}<100 \\
-\end{array}$ & - \\
\hline B-140 & Same & 184 & Same & $\begin{array}{l}1150 \text { to } \\
1200\end{array}$ & 3 times 1 & $2 \cdot 10^{-6}$ & $\begin{array}{c}\text { B } \\
\text { C outside } \\
\text { piece } \\
C \text { center } \\
\text { piece }\end{array}$ & 77, 71 & $\begin{array}{l}26 \\
- \\
-\end{array}$ & $\begin{array}{c}- \\
48 \\
6\end{array}$ & $\begin{array}{c}<20 \\
- \\
-\end{array}$ & $\begin{array}{l}.1 \\
- \\
-\end{array}$ & $\begin{array}{l}<1 \\
- \\
\cdot\end{array}$ & $\begin{array}{l}10 \\
- \\
-\end{array}$ & $\begin{array}{l}100 \\
- \\
-\end{array}$ & - & $\stackrel{10}{.}$ & $\stackrel{10}{\cdot}$ & $\begin{array}{c}20 \\
-\end{array}$ & $\begin{array}{l}160 \\
- \\
-\end{array}$ & : \\
\hline B-143 & Same & 179 & Same & $\begin{array}{l}1150 \text { to } \\
1300\end{array}$ & $\begin{array}{l}3+6 \\
=9\end{array}$ & $2 \cdot 10^{-6}$ & $\begin{array}{l}\mathrm{c} \\
\mathrm{c}\end{array}$ & 59.43 & 66,56 & 90,15 & $<20$ & $:^{1}$ & $\stackrel{<1}{<}$ & 5 & 20 & $<.5$ & 5 & 10 & 15 & 3000 & : \\
\hline B-146 & $\begin{array}{ll}\text { Hfd } \\
\text { (B-55) } \\
\text { C: } \quad 435 \\
\text { N: } & 66 \\
\text { Fe: } & 15 \\
\text { Si: } & 10\end{array}$ & 230 & Same & 1150 & 1 & $6 \cdot 10^{-6}$ & c & 400 & 32 & - & $<20$ & $<.1$ & $<1$ & 5 & 20 & $<.5$ & 1 & 10 & 10 & $<100$ & - \\
\hline B-145 & $\begin{array}{ll}\text { Hfd } \\
\text { (B-56) } \\
\text { C: } & 485 \\
\text { N: } & 55 \\
\text { Fe: } & 15 \\
\text { Si: } & 15\end{array}$ & 238 & Same & $\begin{array}{l}1150 \text { to } \\
1200\end{array}$ & 3 & $2 \cdot 10^{-6}$ & c & 130 & 10,12 & - & $<20$ & $<.1$ & $<_{1}$ & 3 & 20 & .5 & 2 & 10 & 15 & $<100$ & - \\
\hline B-164 & $\begin{array}{l}\text { Biscuit } \\
\text { (Lot } 687 \text { ) } \\
\text { Same as above }\end{array}$ & 303 & $\begin{array}{l}\text { Globar Res. Fce. } \\
\text { MCF } 700 \text { Oil-Diff. P. } \\
\text { MB } 100 \text { Booster } \\
556 \text { Kinney Forep. } \\
\text { No Cold Trap }\end{array}$ & 1190 & 3 & $3.5 \cdot 10^{-5}$ & $\begin{array}{l}\text { C } \\
\text { B }\end{array}$ & 38,31 & $\stackrel{25}{-}$ & : & $<20$ & $: 1$ & 2 & $\stackrel{7}{.}$ &.$^{7}$ & 10 & $\stackrel{2}{.}$ & 5 & 20 & 50 & Pb: 3 \\
\hline B-165 & Same & 312 & Same & 1190 & 5 & $3.4 \cdot 10^{-5}$ & $\begin{array}{l}\text { C } \\
\text { B }\end{array}$ & 37,40 & $\stackrel{25}{-}$ & : & $<20$ & $\because$ & $\stackrel{1}{.}$ & 30 & 30 & 10 & $\stackrel{2}{-}$ & $\stackrel{5}{-}$ & 20 & 150 & Po: 3 \\
\hline
\end{tabular}


HEATS AND FREE ENERGIES OF FORMATION IN KILOCALORIES PER GRAM-ATOM

OF CARBON AT $298^{\circ} \mathrm{K}$

$\therefore \ldots$

$\vdots \ldots . .{ }^{\prime}$

(......

1...:

(......

$\because \because$

$\because \because:$

$\because \ldots$

$\vdots .$.

$\therefore$

:...: :

$\therefore$ :...:

\begin{tabular}{|c|c|c|c|c|}
\hline Film No. & $\begin{array}{c}\text { h k 1 } \\
\text { used }\end{array}$ & Type of Pattern & $\begin{array}{c}a_{0}(\AA) \\
\text { for Type 1 }\end{array}$ & $\begin{array}{c}a_{0}(\AA) \\
\text { for Type 2 }\end{array}$ \\
\hline 4065 & $\begin{array}{c}531 \\
600 \\
620\end{array}$ & Debye-Scherrer & 4.9532 & 4.9409 \\
\hline 4065 & 620 & Debye-Scherrer & 4.9528 & 4.9422 \\
\hline $\begin{array}{c}4065.1 \\
\text { Position A }\end{array}$ & 620 & Back Ref lection & 4.9473 & 4.9418 \\
\hline $\begin{array}{c}4065.2 \\
\text { Position B }\end{array}$ & 620 & Back Ref lection & 4.9453 & 4.9406 \\
\hline
\end{tabular}
INCLUSIONS OF LIQUATION LAYER
Table XVII

LATTICE CONSTANTS FOR

UC, UO, AND UN

\begin{tabular}{|c|c|}
\hline Compound & $a_{0}(\AA)$ \\
\hline UC & 4.961 \\
UO & 4.920 \\
UN & 4.890 \\
\hline
\end{tabular}

Values by Rundle et al.

(Ref. 6)

Converted from kX to

$\AA$ units.
LATTICE PARAMETERS OF CUBIC PHASES IN OF MELT B-2 (TABLE II)

\section{Table XIX}

LATTICE PARAMETERS OF CUBIC PHASES IN INCLUSIONS OF TOP LAYERS OF MELTS B-390 AND B-405 (Table IV)

\begin{tabular}{|c|c|c|c|}
\hline \multirow[t]{2}{*}{$\begin{array}{c}\text { Sample } \\
\text { No. }\end{array}$} & \multirow[t]{2}{*}{$\begin{array}{c}\text { Fi } 1 \mathrm{~m} \\
\text { No. }\end{array}$} & \multicolumn{2}{|c|}{$\begin{array}{c}a_{0}(\AA) \\
\text { calculated } \\
\text { from (111) }\end{array}$} \\
\hline & & $U(C, O, N)$ & $\mathrm{UO}_{2}$ \\
\hline B-390-TL & 3909 & 4.90 & 5.46 \\
\hline B $-405-T L$ & 3917 & 4.93 & 5.47 \\
\hline
\end{tabular}




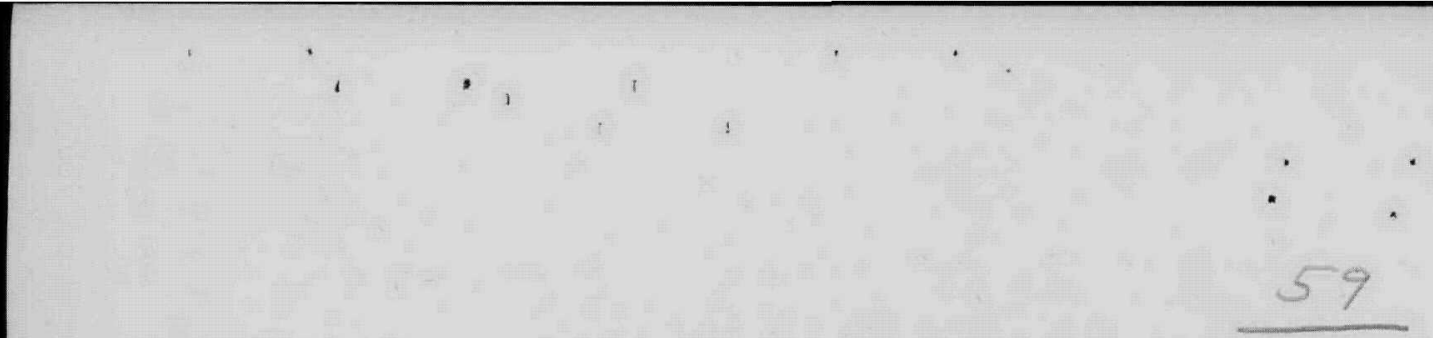

RESISTANCE FURNACE

FIRST STAGE OF DEVELOPMENT

DRWG \# I

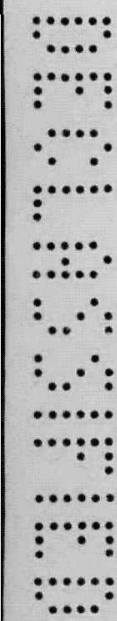

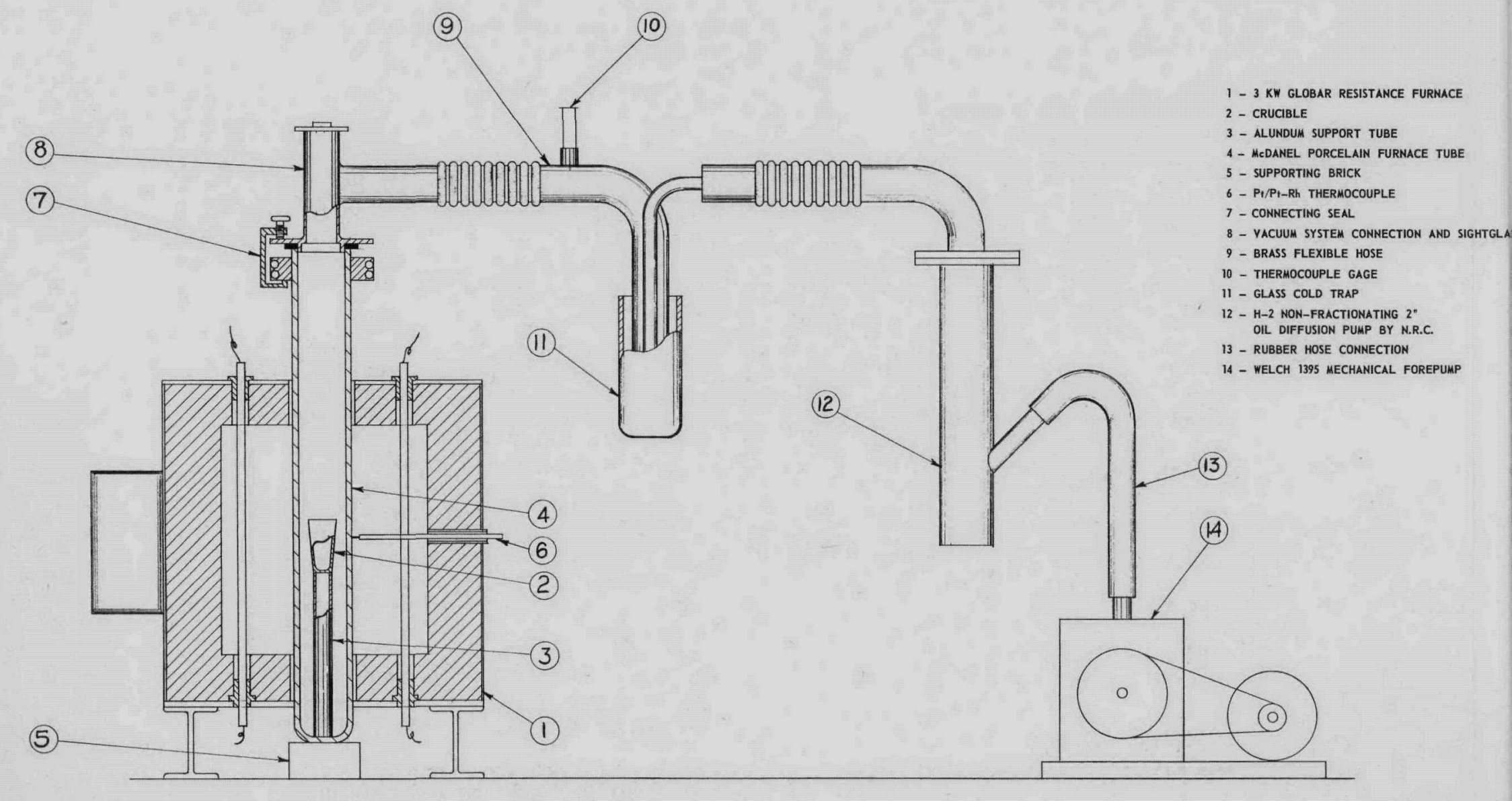


SEAL BETWEEN FURNACE

TUBE AND BRASS HEAD DRWG \# 2

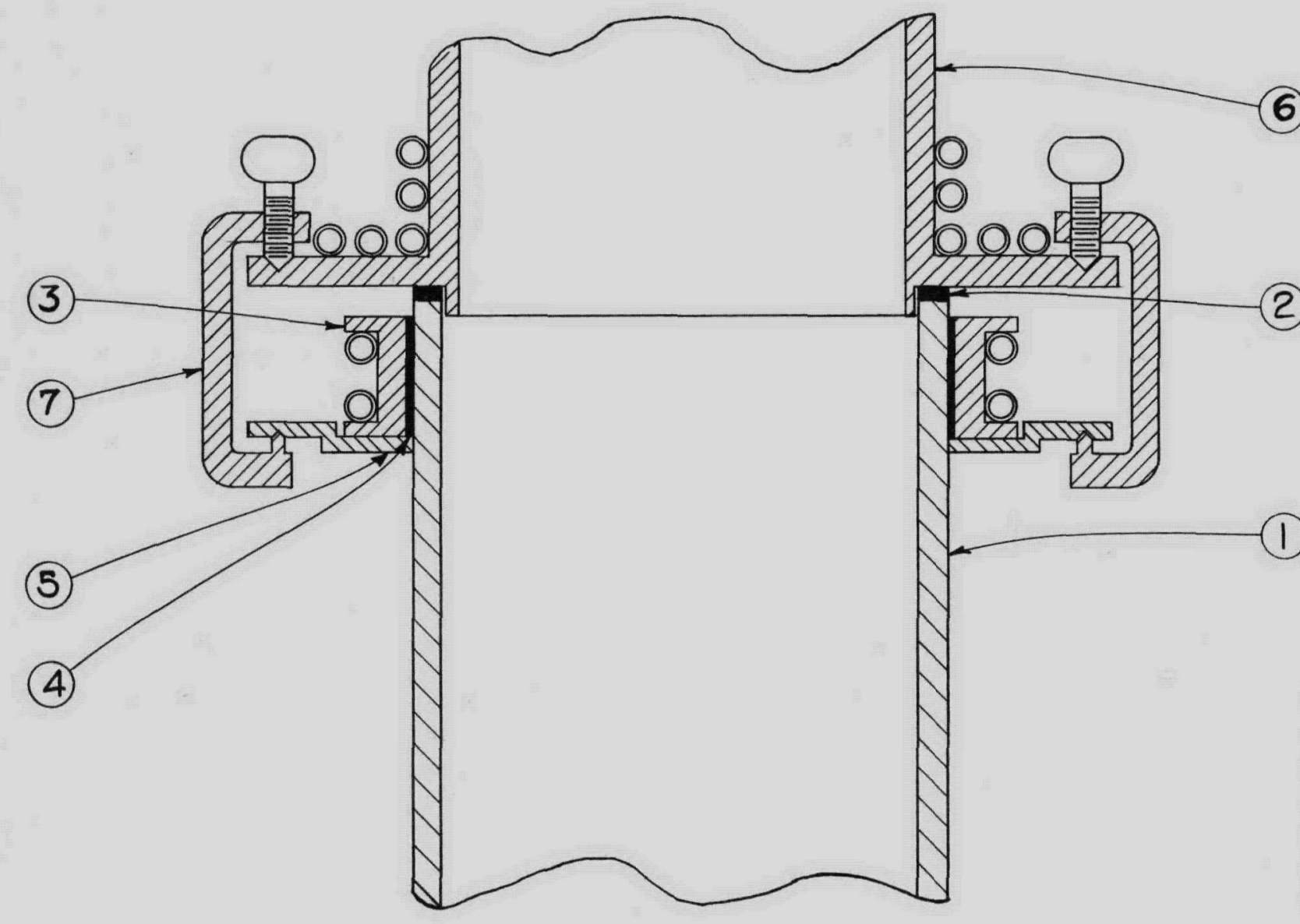

1 - Medanel PORCELAin furnaCE tUBE 2 - NEOPRENE GASKET

3 - BRASS RING CEMENTED TO TUBE

4 - SAUEREISEN CEMENT

5 - LOOSE SUPPORTING RING

6 - WATER COOLED FLANGE OF BRASS HEAD

7 - C-CLAMPS 


\section{GLOBAR RESISTANCE FURNACE}

SECOND STAGE OF DEVELOPMENT

$\because \cdots$

$\because \cdots$

$\because \cdots$

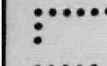

$\ldots$

$\therefore$

$\therefore$

$\cdots \cdot:$

(......

$\because \cdots$

$\cdots$

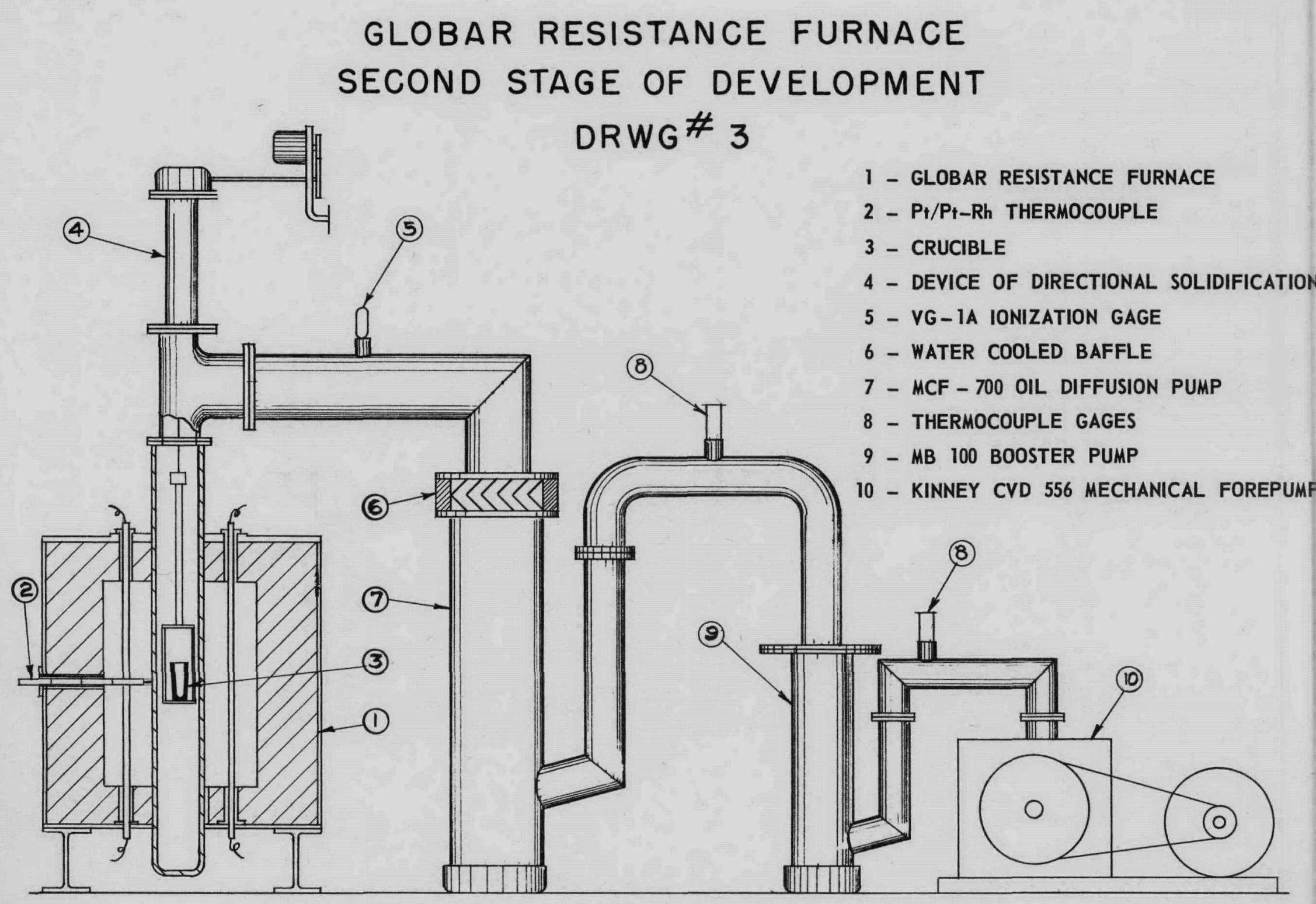

EFE 
:.....:

¿...:

…...

…...

$\because \because$

$\because \because$

$\because \because \because$

$\vdots . .$.

$\therefore . .$.

!...:

…...

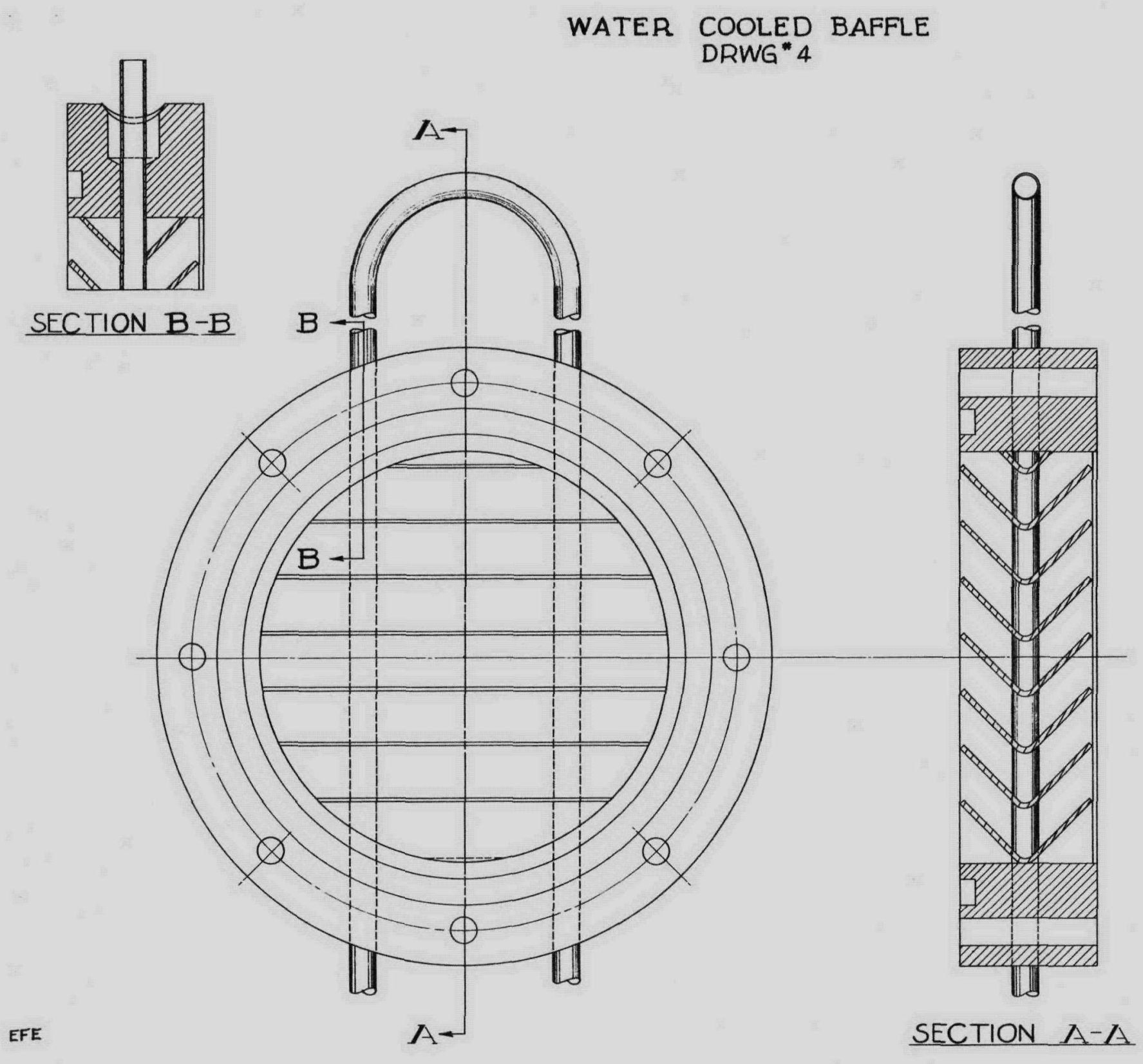


DRWG." 5

APPARATUS FOR DIRECTIONAL SOLIDIFICATION

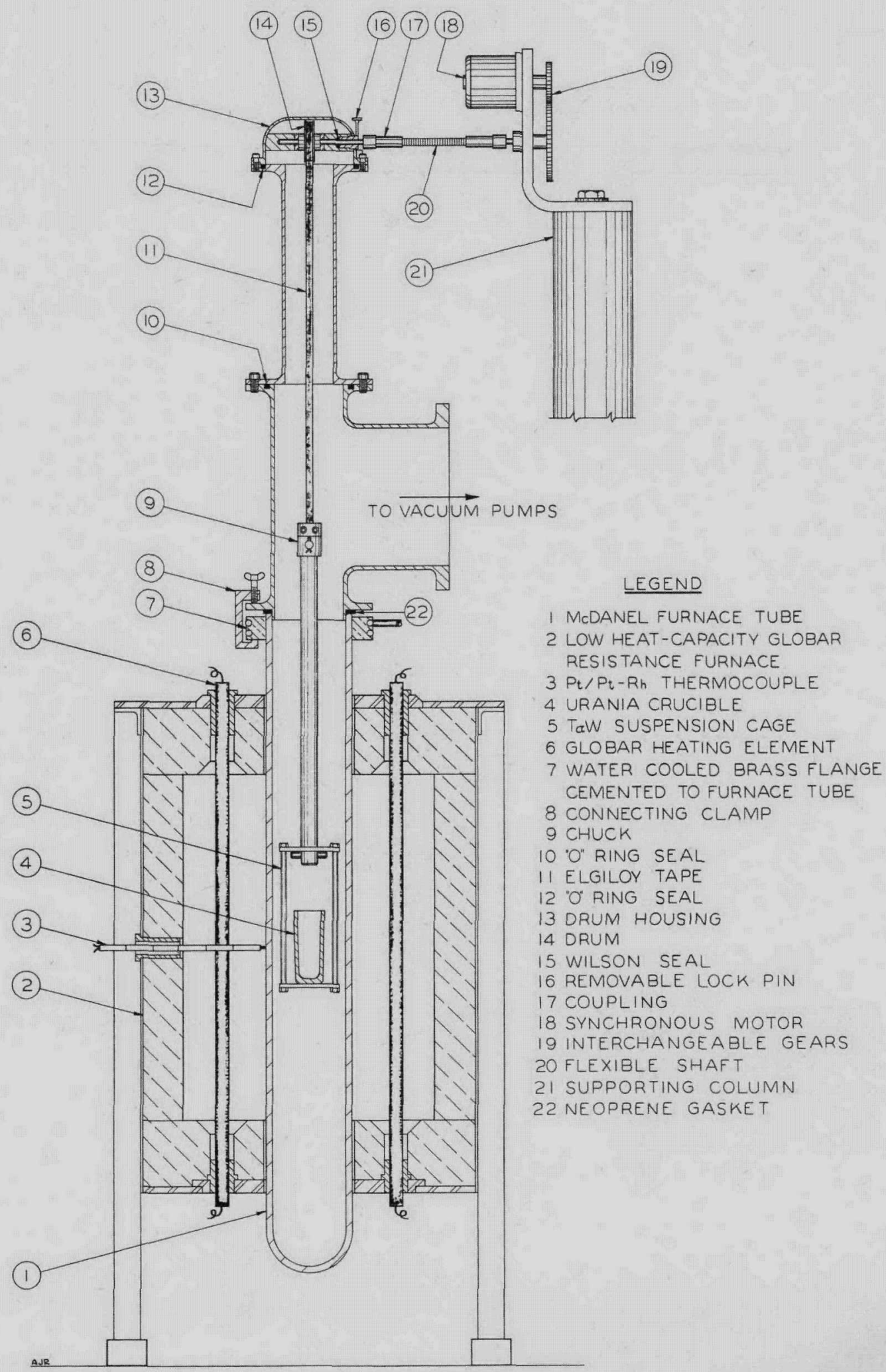


FURNACE AND VACUUM SYSTEM

SCHEMATIC DRAWING

DRWG ${ }^{*} 6$

…:.:

$\vdots \ldots . .:$

........

$\cdots: .:$

$\because \because$

$\because \because$

$\because \cdots$

$\vdots \ldots$

$\therefore \ldots$

$\vdots \ldots:$.

$\therefore . . .:$

(2)

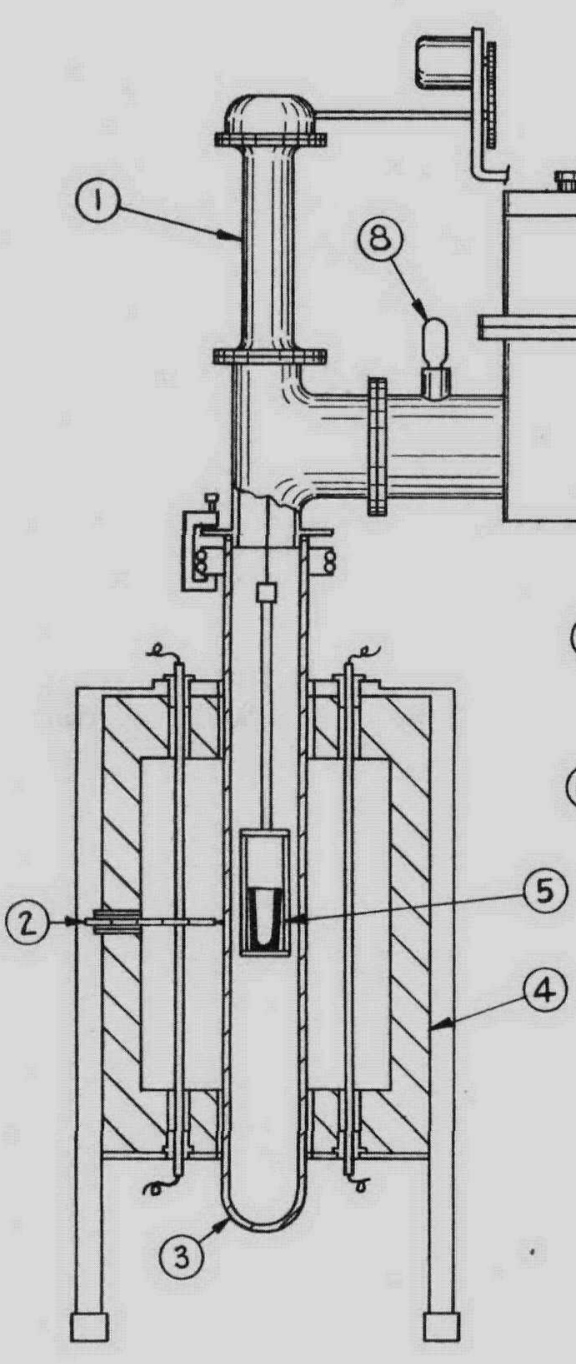

.
1-CRUCIBLE SUSPENSION

2- $\mathrm{Pt}_{\mathrm{t}} / \mathrm{Pt}_{\mathrm{t}} \mathrm{Rh}$ THERMOCOUPLE

3-MCDANEL FURNACE TUBE

4-LOW HEAT-CAPACITY GLOBAR

RESISTANCE FURNACE

5-CRUCIBLE

6-OIL DIFFUSION PUMP D.P.I. MCF 700 7-WATER COOLED BAFFLE

8-ION OR COLD DISCHARGE GAGES 9-COLD TRAP (CHEVRON TYPE)

10-THERMOCOUPLE GAGES

II-BOOSTER PUMP D.P.I. MB 200

12-BELLOWS

13-WELCH 1397 FOREPUMP

14-COLD TRAP (POT TYPE)
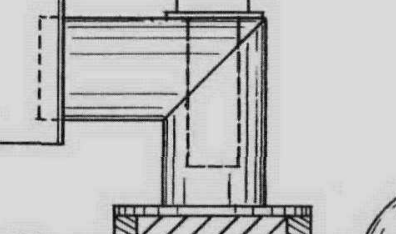

(10)

(7)

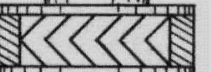

(6)
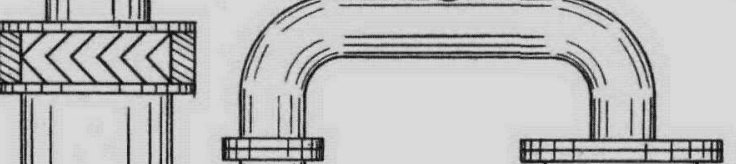

(6)
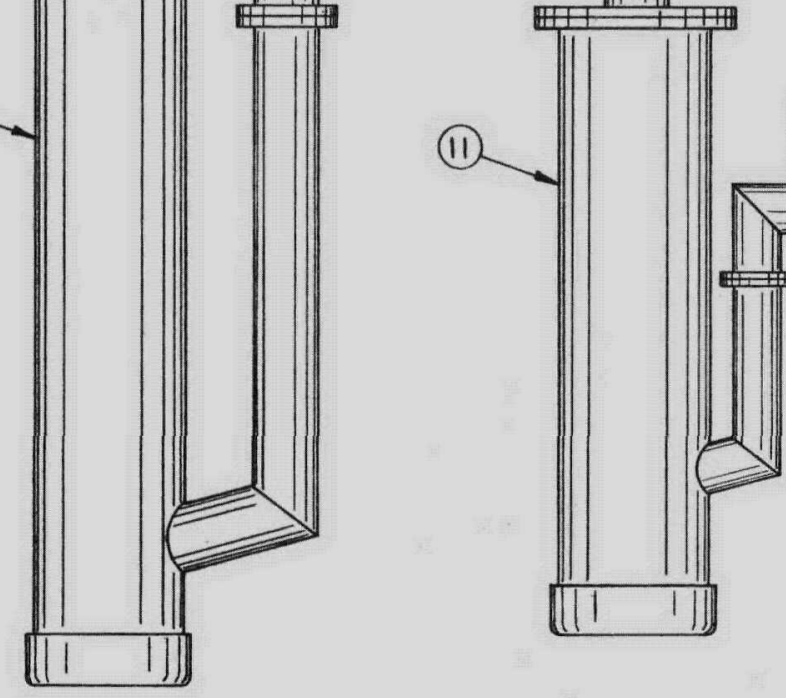

(10)
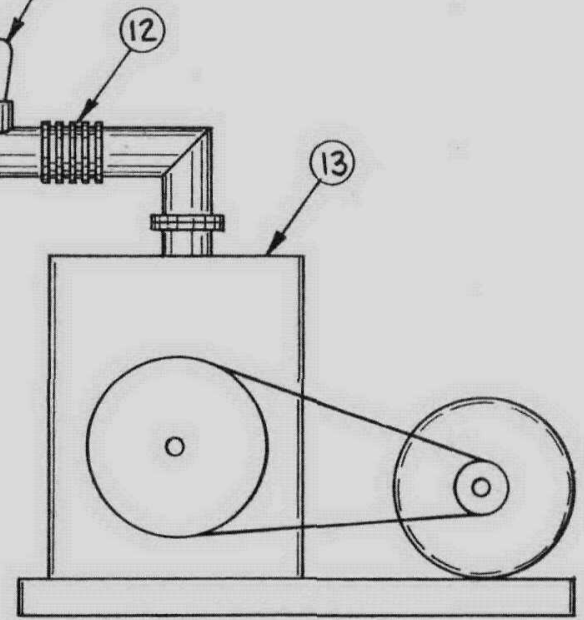


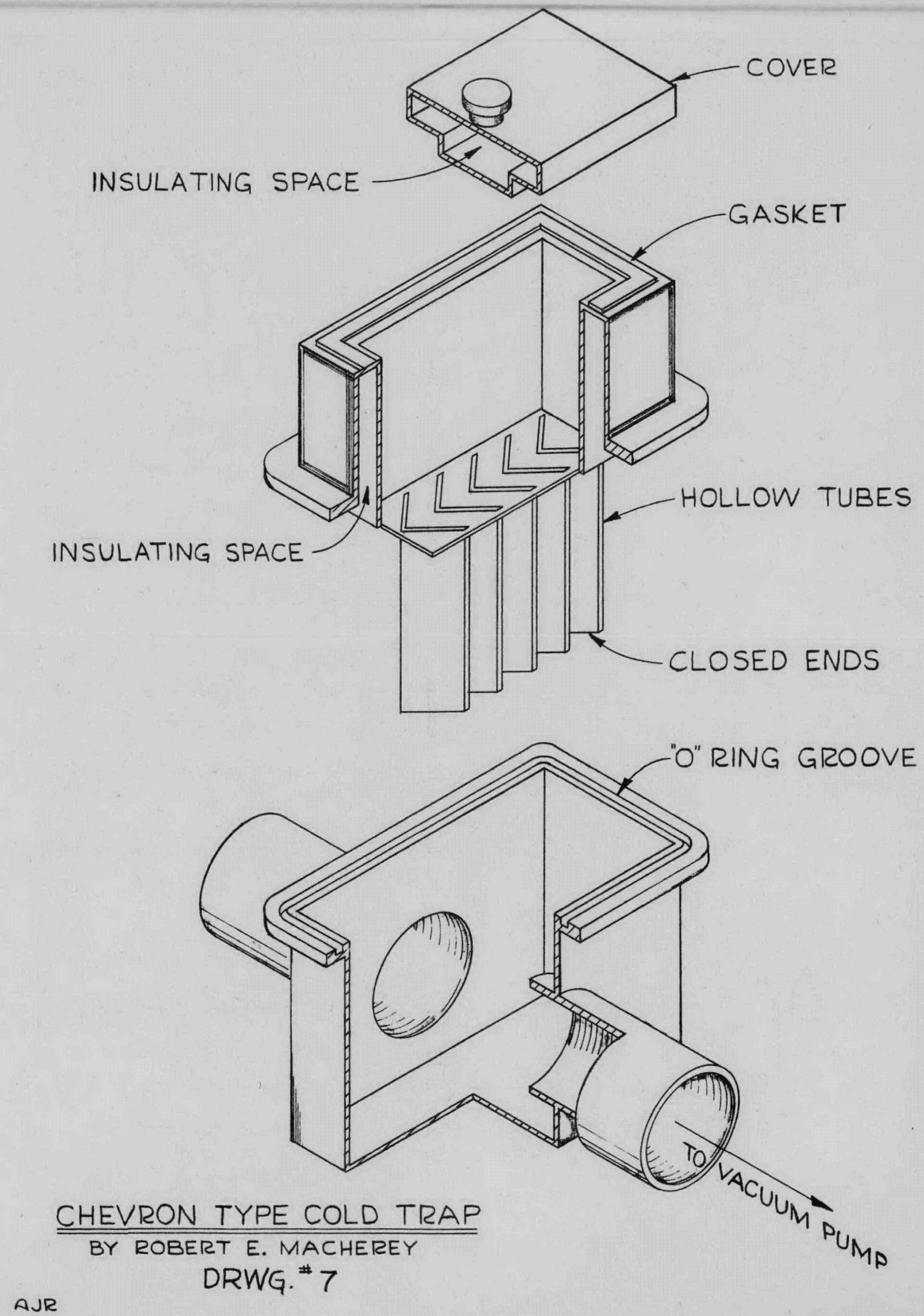


GAS VACUUM INDUCTION FURNACE FIRST STAGE OF DEVELOPMENT DRWG \# 8

(16)

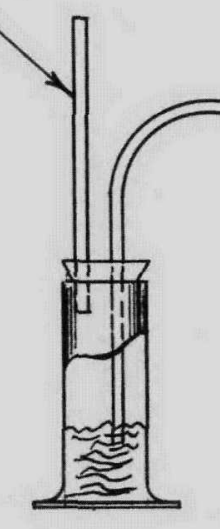

(14)
(15)

(9)

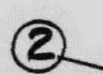

(3)

(4)

(5)

(1)
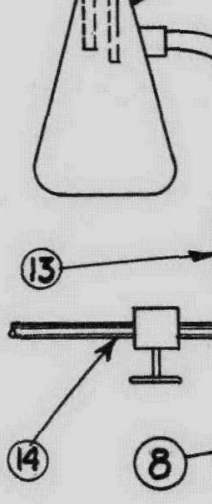

(6)
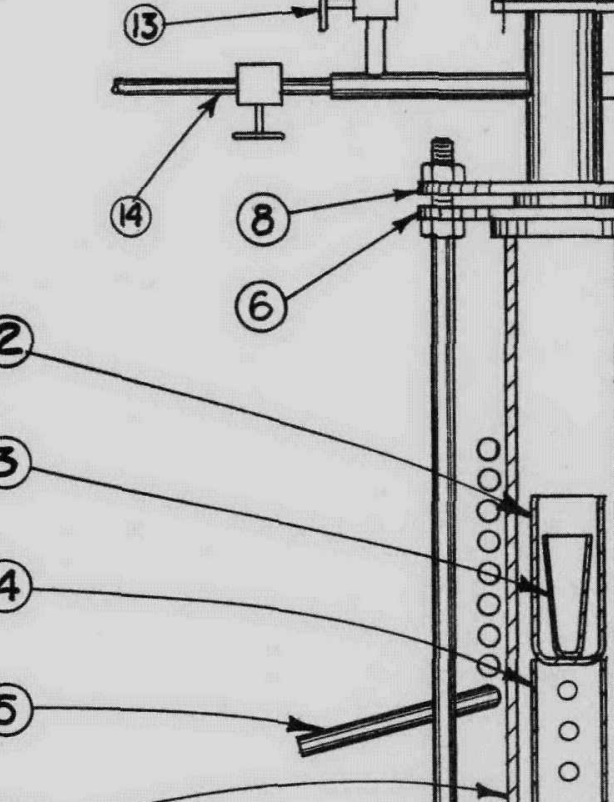
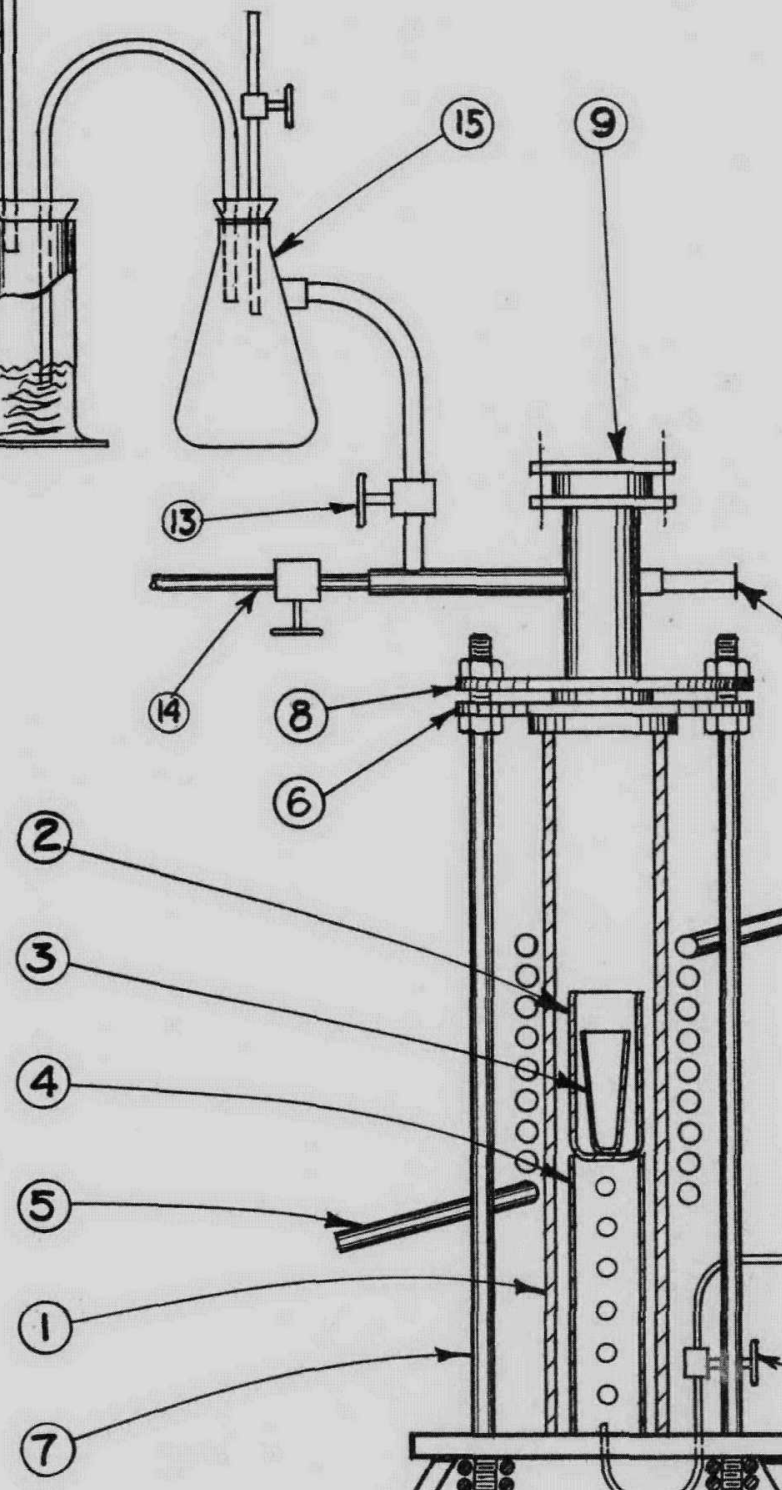

- VYCOR FURNACE TUBE

2 - PROTECTIVE ALUNDUM CRUCIBLE

3 - MELTING CRUCIBLE

4 - CRUCIBLE SUPPORT

5 - INDUCTION COIL

6 - STATIONARY TOP PLATE

7 - SPRING LOADED TIE RODS

8 - REMOVABLE TOP PLATE

9 - SIGHT GLASS

10 - THERMOCOUPLE GAGE

11 - GAS TANK

12 - GAS INLET VALVE

13 - GAS OUTLET VALVE

14 - TO VACUUM SYSTEM

15 - SAFETY FLASK

16 - GAS OUTLET \& TELL TALE

(10)

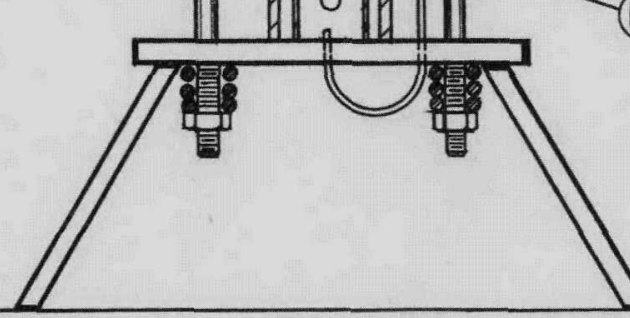

(12)

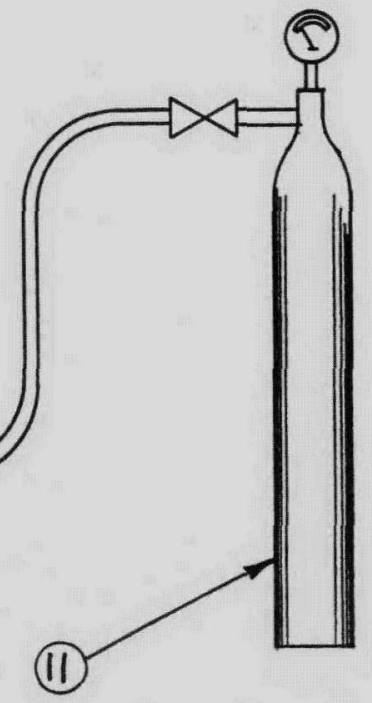




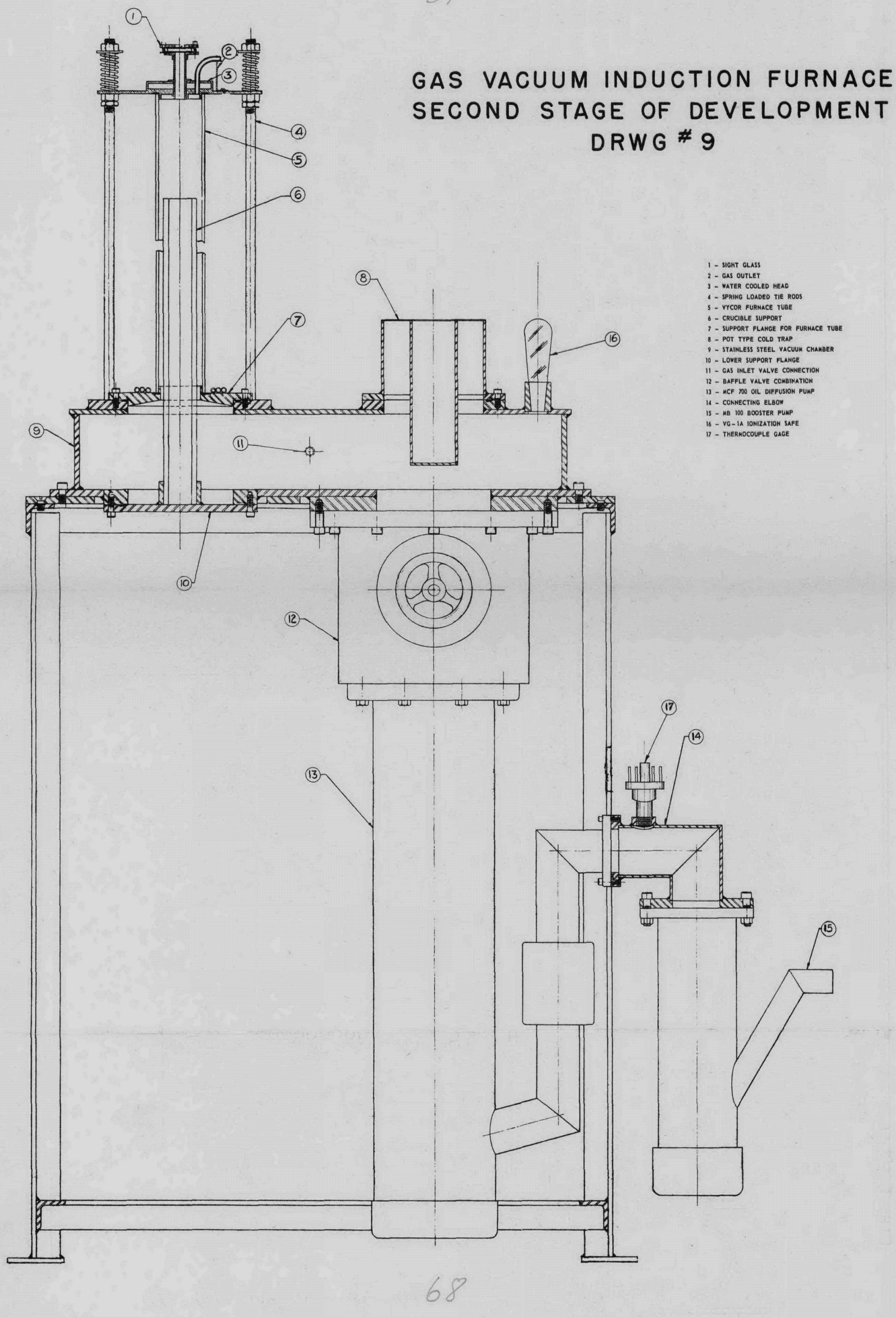

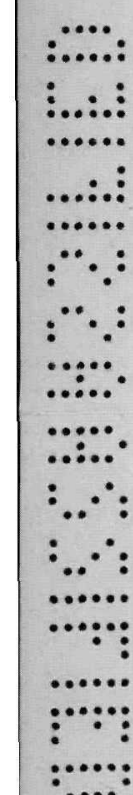


:....:

$\vdots \ldots:$ :

…..

…....

$\because \because$

$\because \because$

$\because \because$.

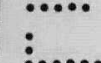

$\therefore \therefore$

¿...:.

$\therefore . . .:$

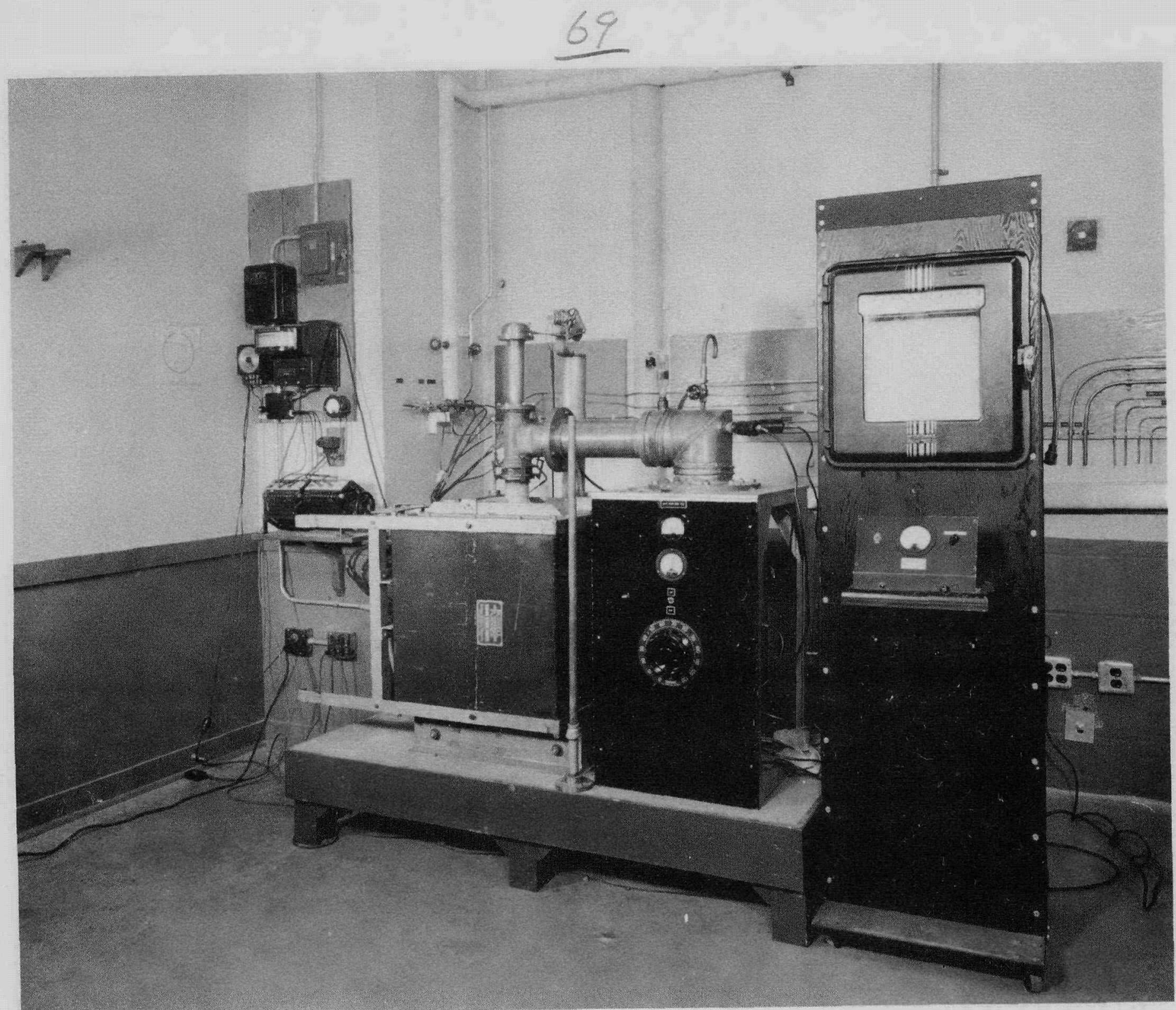

Photograph \#1. Globar Resistance Furnace, Second Stage of Development. 


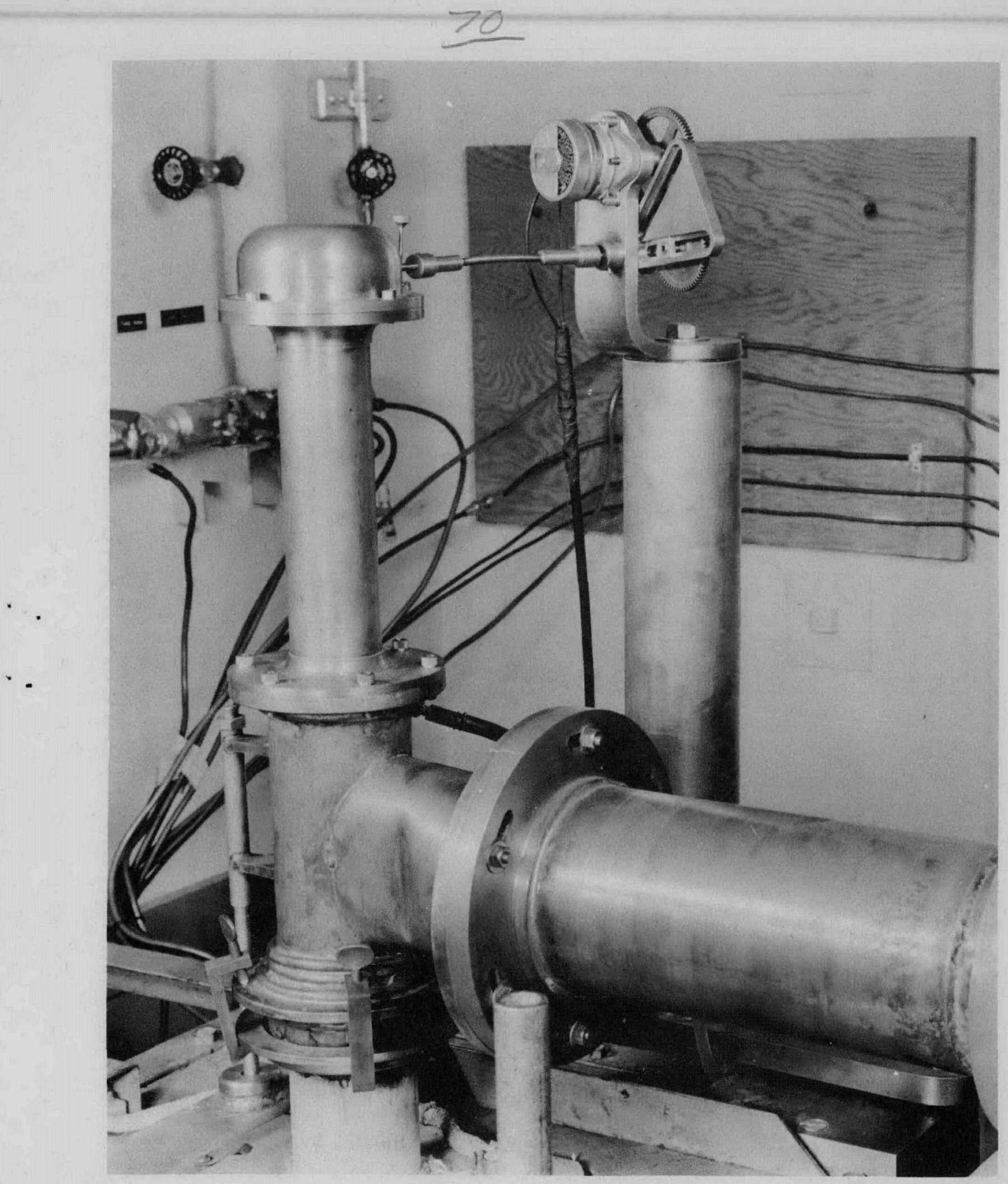

Photograph \#2. Device of Directional Solidification. 
:......

:....:

?......

....: :

(......

$\because \because:$

: “ :

......

$\vdots . .$.

$\therefore .$.

:...: :

…...:

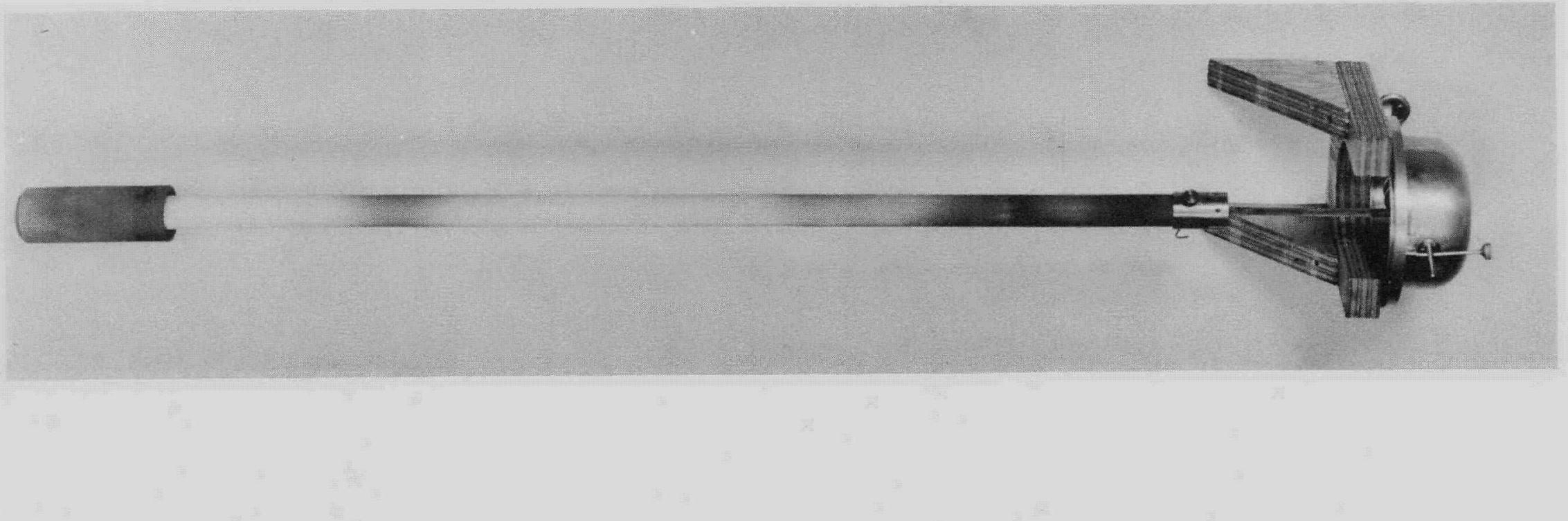

Photograph \#3. Direct Suspension of Urania Crucible in Device of Directional Solidification. 

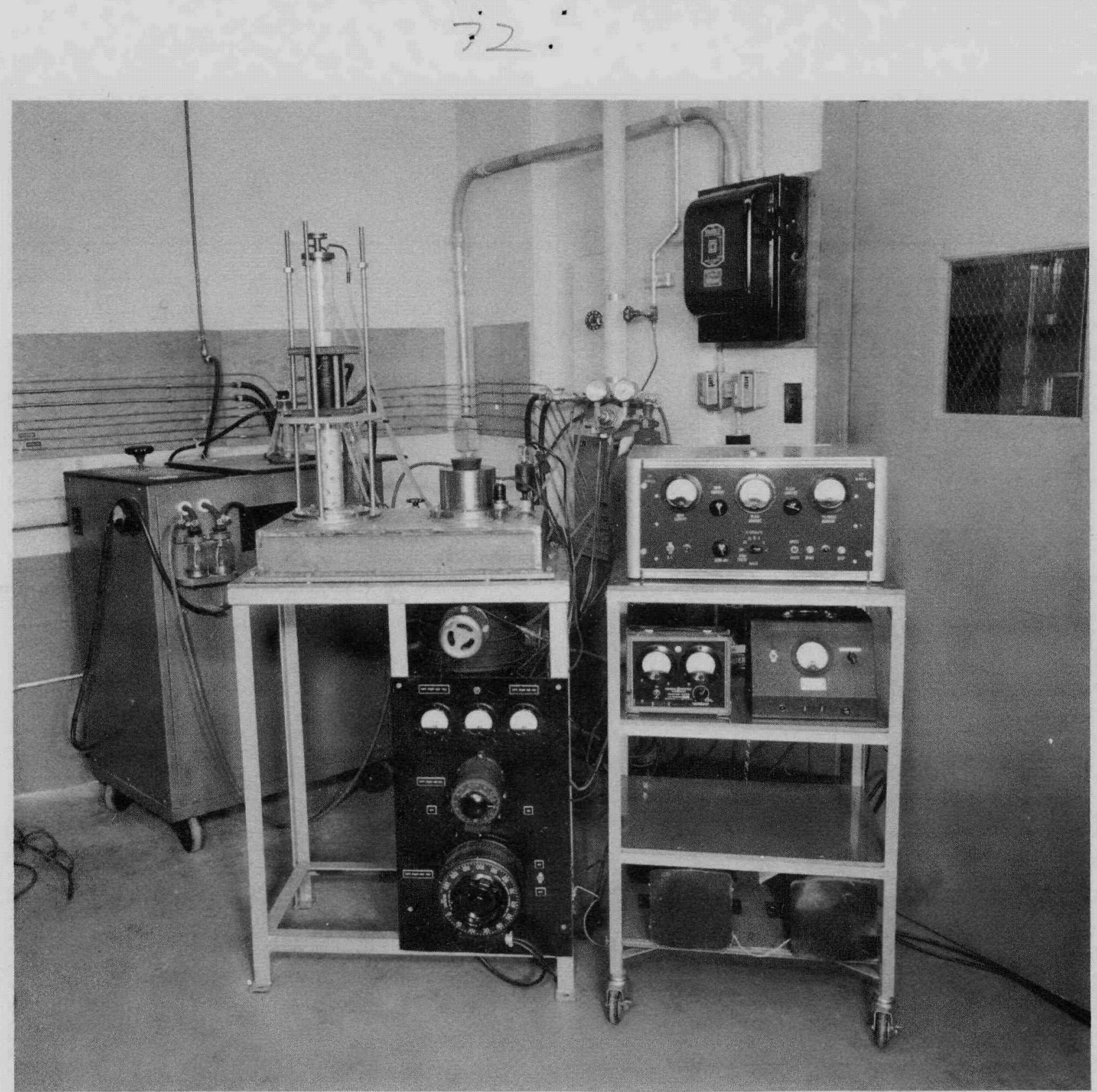

Photograph \#4. Gas-Vacuum Induction Furnace, Second Stage of Development。 
Figures I to 3. Microstructure of 1949 Biscuit Metal (Table XVI)。

Figure I

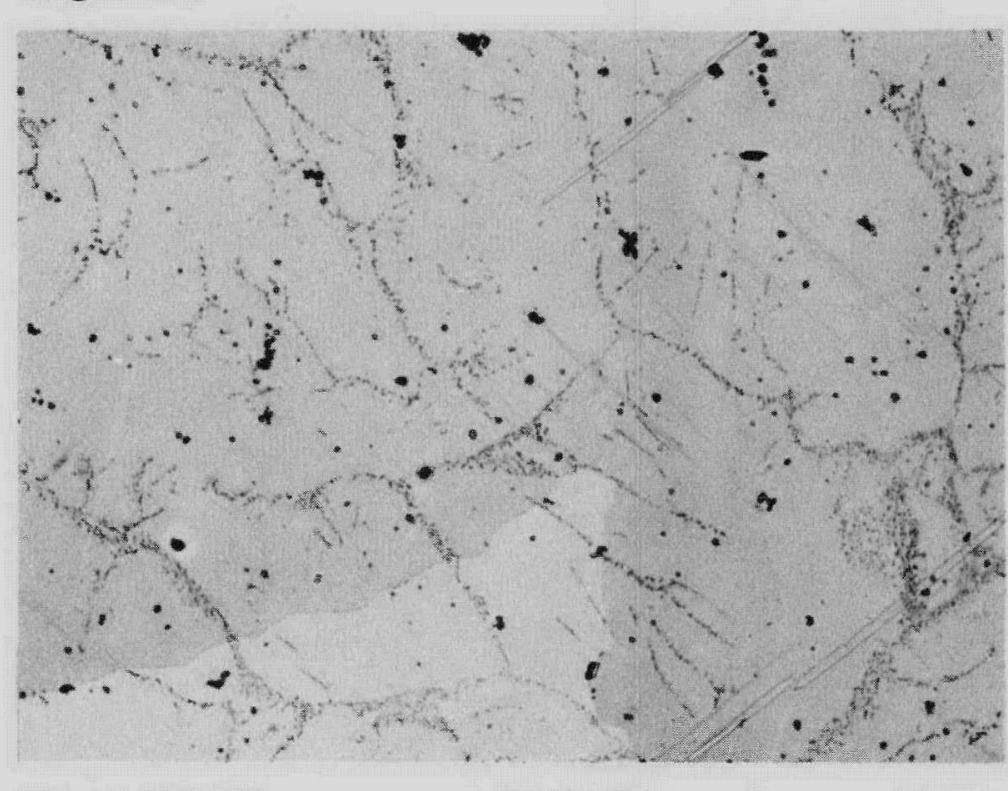

Micro 16026 $(\$ 691)$
Figure 2

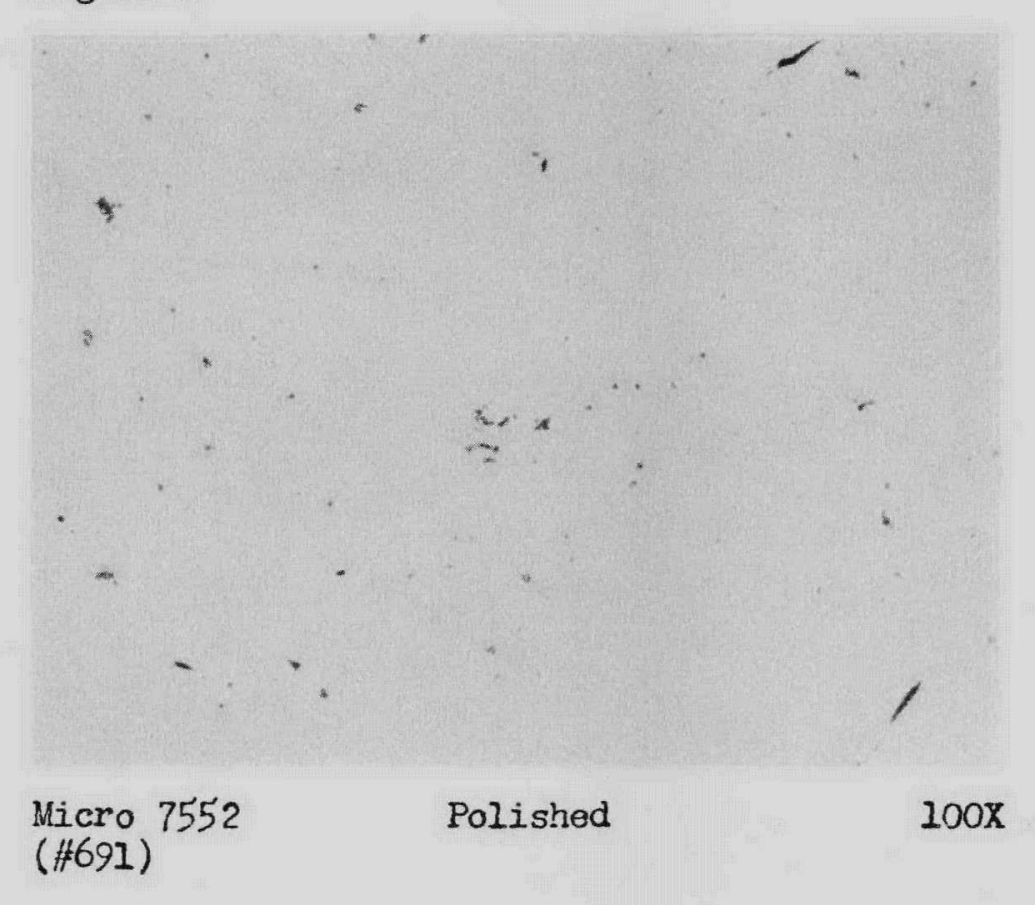

Figure 3

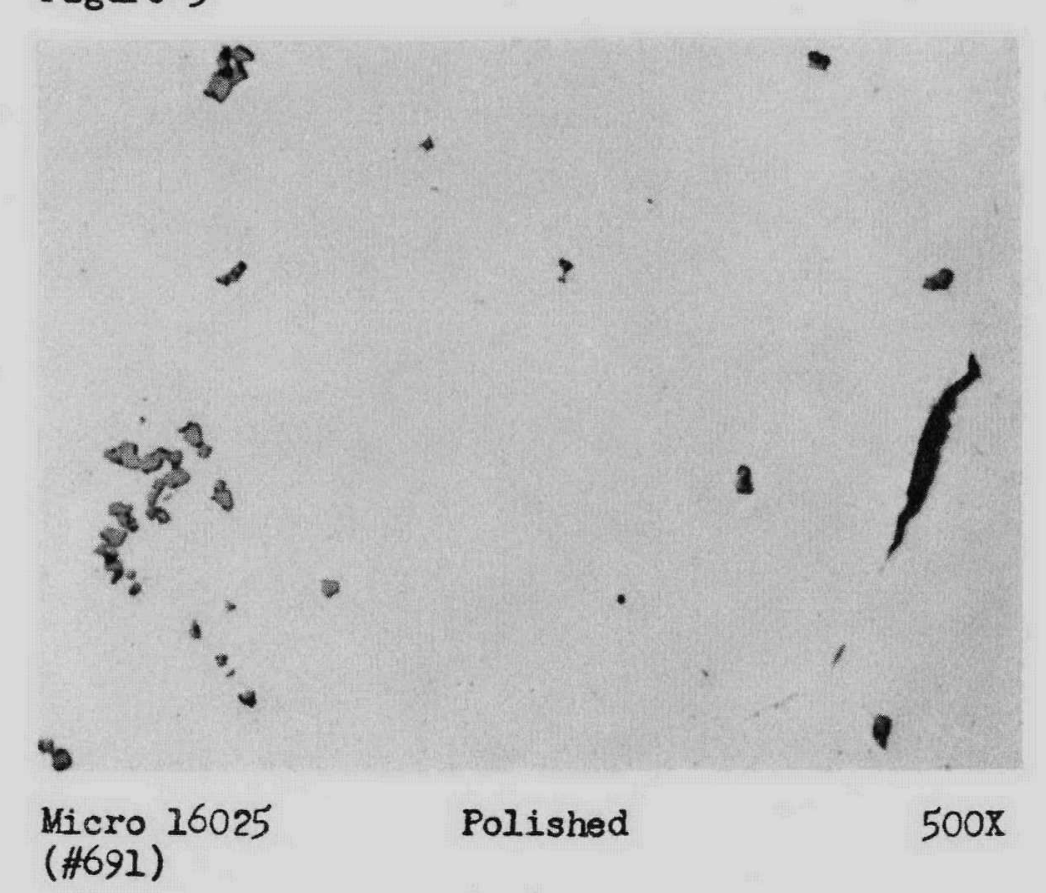

Figures 4 to 6. Microstructure of 1953 Biscuit Metal (Table XVI)。

Figure 4

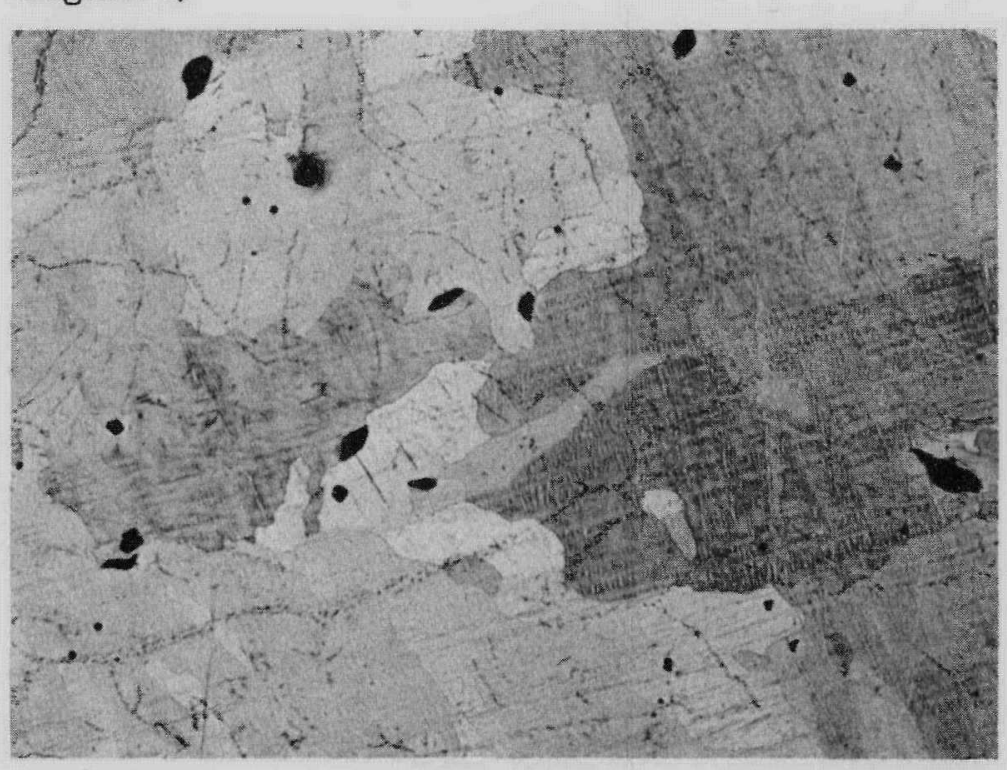

Micro 16028 $(B-530)$
Figure 5

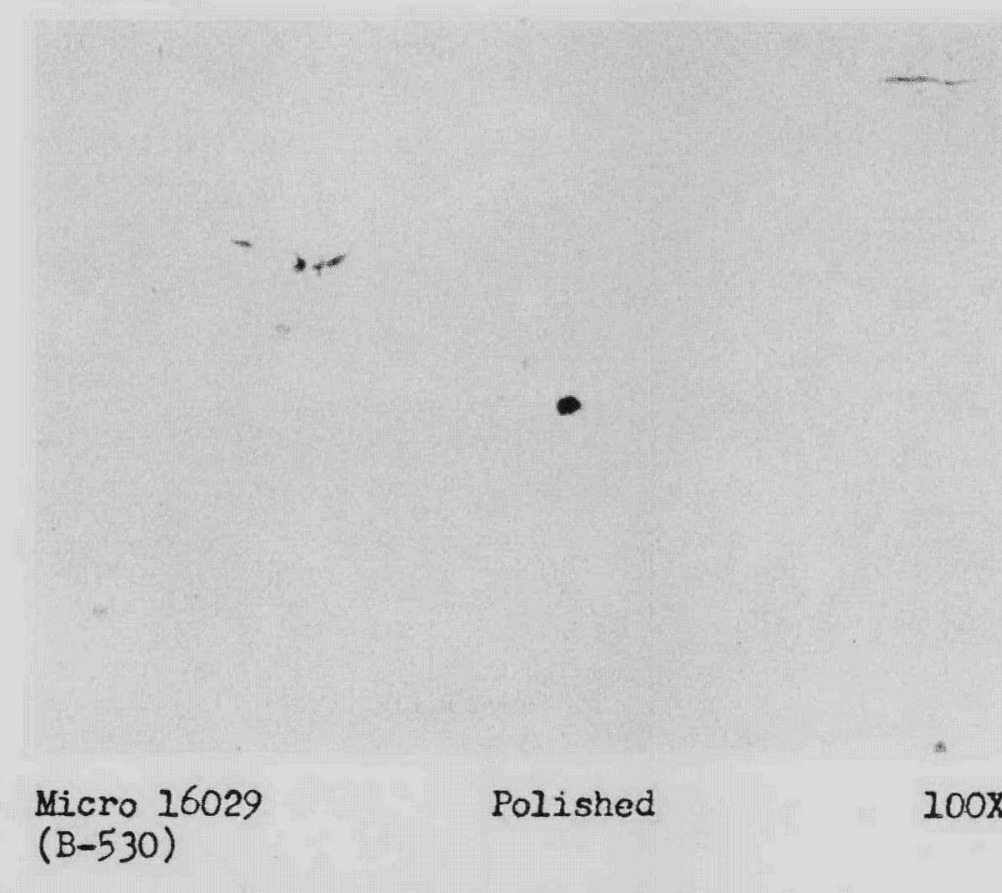

Figure 6

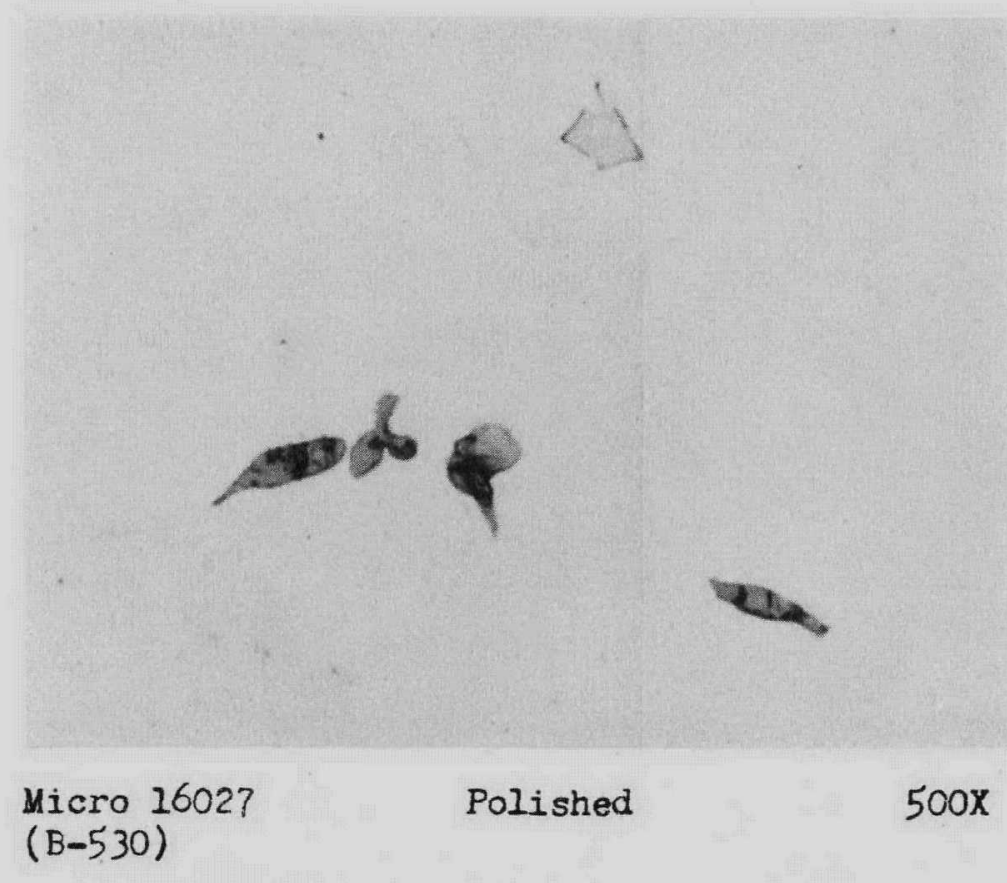


Figures 7 and 8. Microstructure of Remelted Biscuit Metal (Table III, Group I) Figure 7
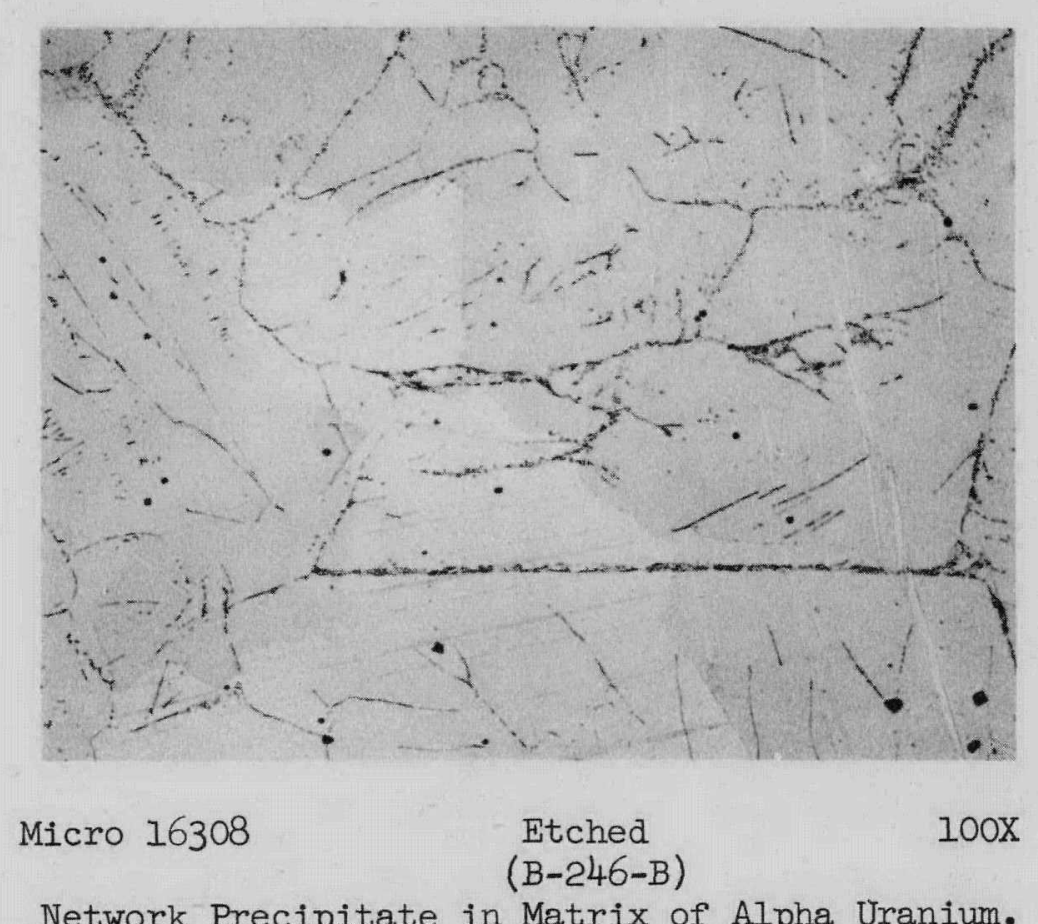

Network Precipitate in Matrix of Alpha Uranium.

Figure 8

Micro 16307

Etched

$(\mathrm{B}-246-\mathrm{B})$

$100 x$

Few Inclusions.

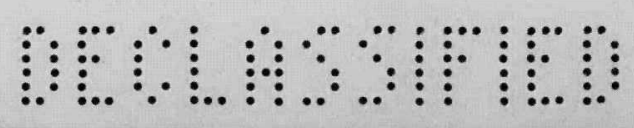


Figures 9 to 16. Effect of Remelting on Reactor Grade Slugs (Table III, Group I).

Figure 10

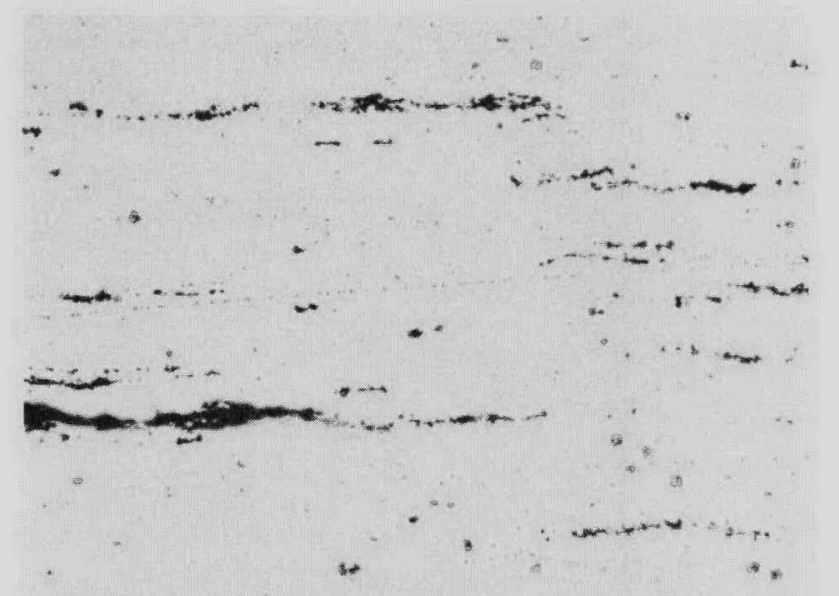

$\begin{array}{ll}\text { Micro } 13728 & \begin{array}{l}\text { Electropolished } \\ \text { Hanford Slug }\end{array} \\ \text { H-355) } & \text { 100X }\end{array}$

\section{Figure 13}

Figure 12

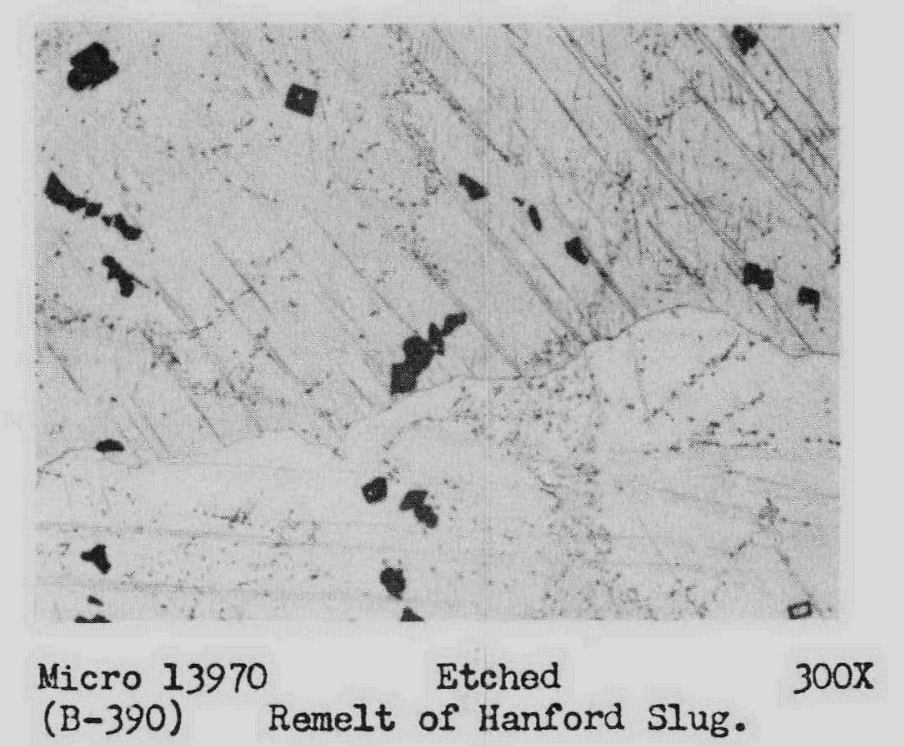

Figure 14

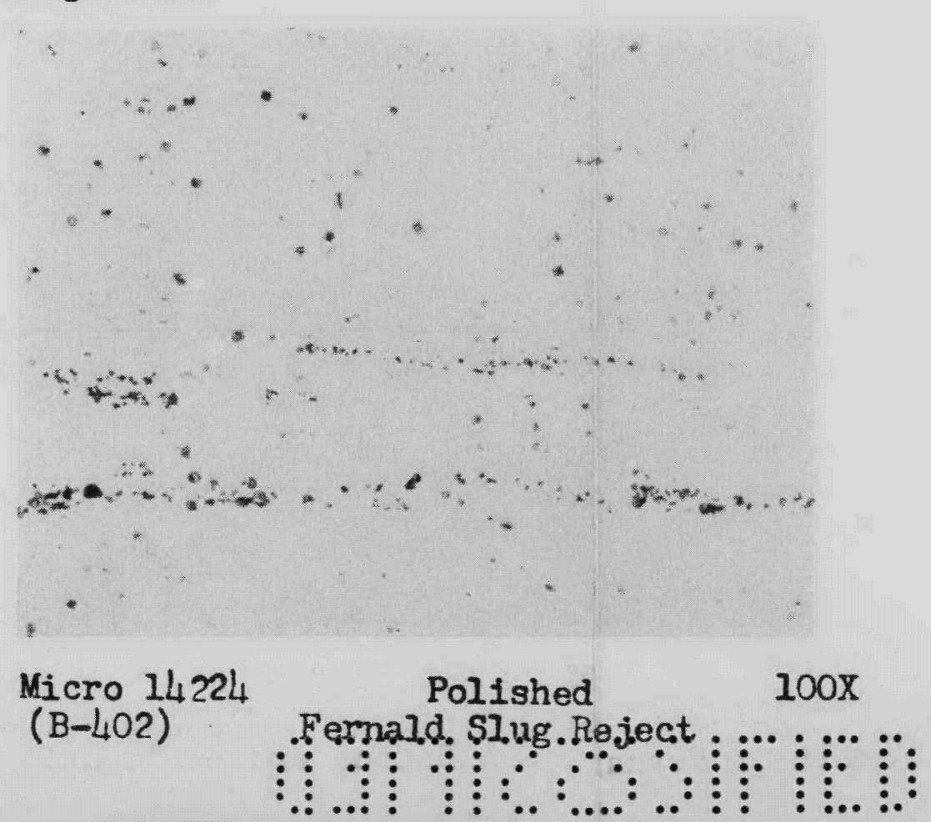

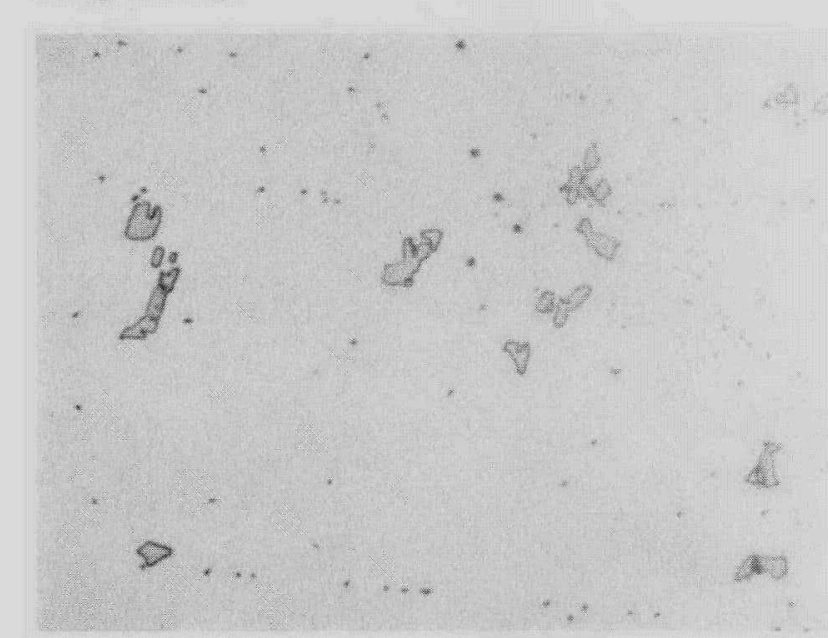

Micro 13971 Hand Polished 300X (B-390) Remelt of Hanford Slug.

Figure 15

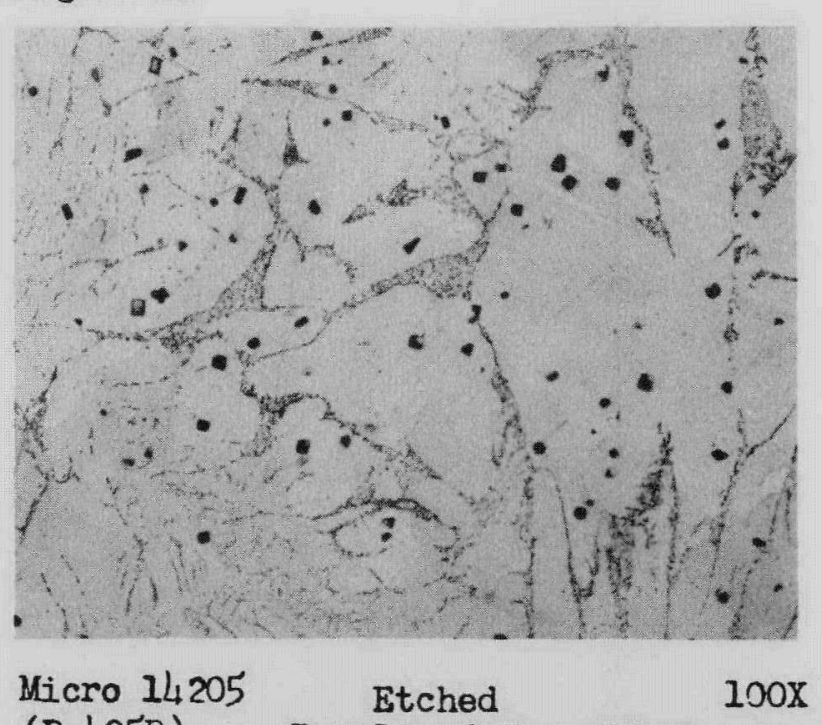
$100 x$ $\begin{array}{ll}\text { Micro } 14205 & \text { Etched } \\ (\mathrm{B}-405 \mathrm{~B}) & \text { Remelt of Fernald Slug Reject }\end{array}$
Figure 11

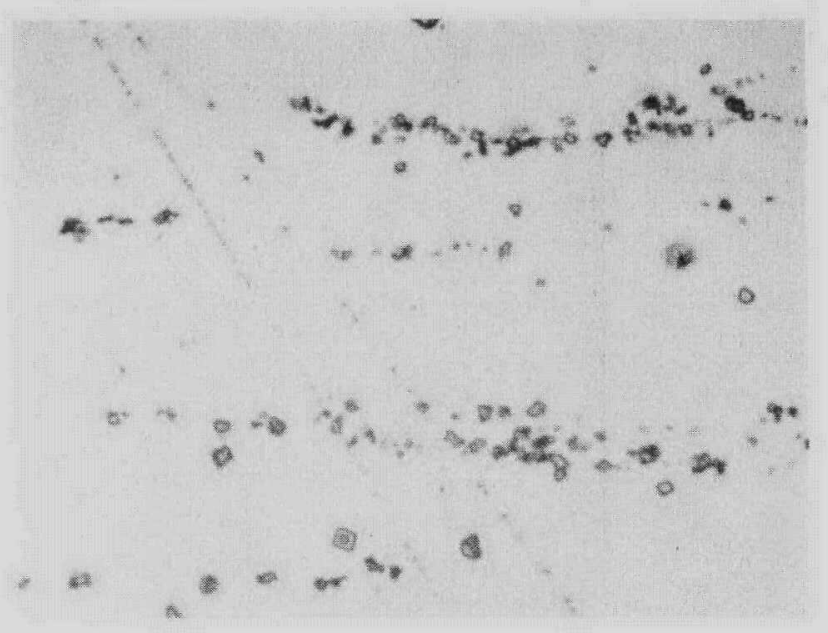
$200 x$ $\begin{array}{ll}\text { Micro } 13730 & \text { Hand Polished } \\ (\mathrm{B}=355) & \text { Hanford Slug }\end{array}$

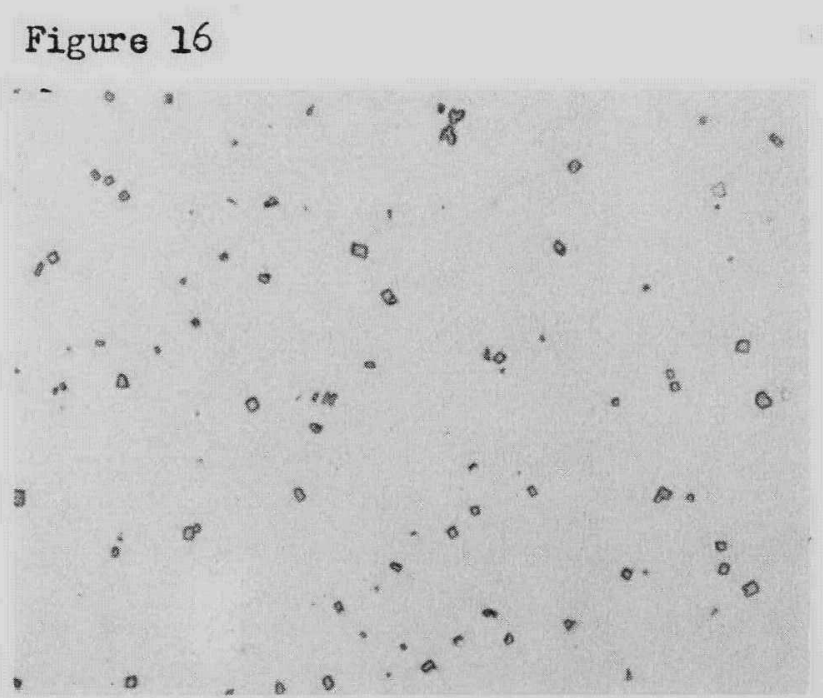

Micro 14203 Polished $100 x$

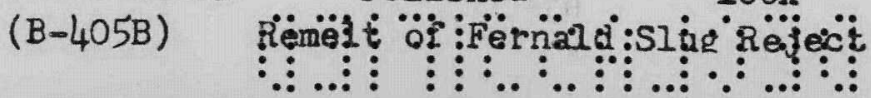


Mgures 27 to 21. Microstructure of Graphite Melted Ingot K-5 (Table I).

PIgure 17

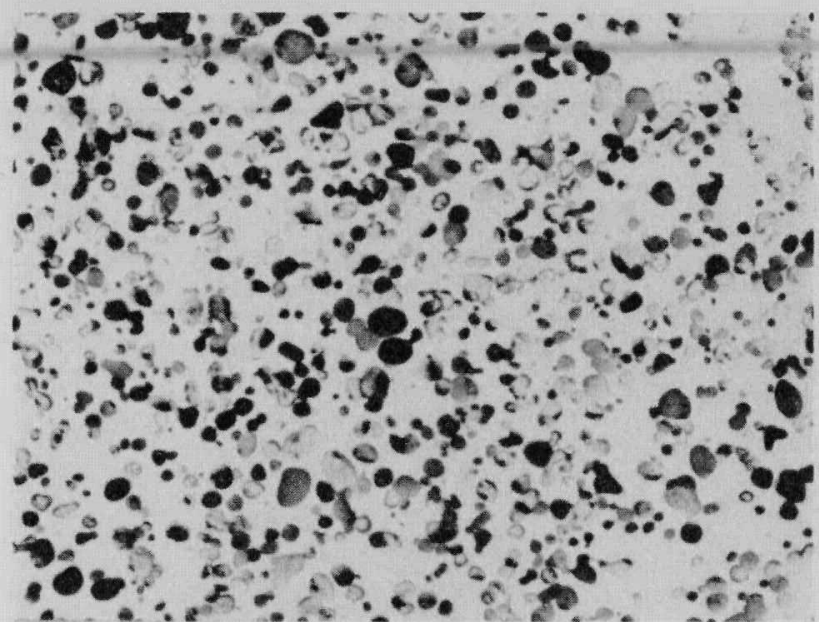

vicro 631,12
Pol1shed

Top Liquation Layer
Figure 18

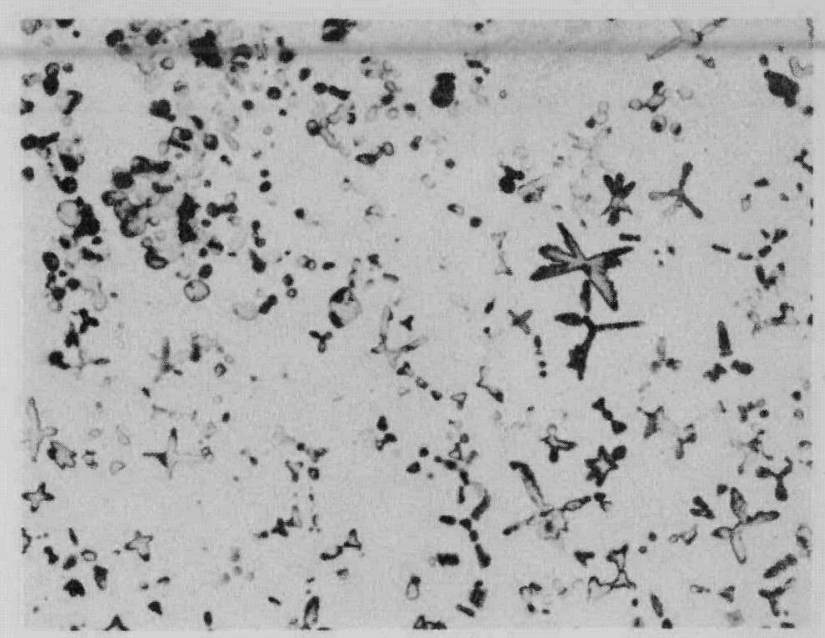

Hicro 63/.1b Polishad

Dendritas in Lower Liquation Layer

Figure 27

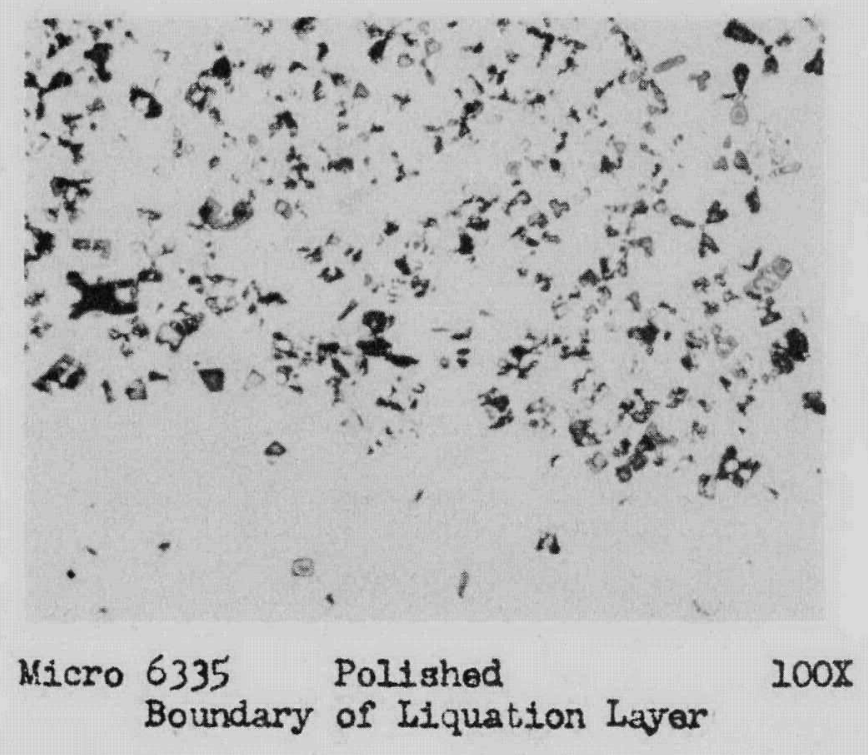

Figure 20

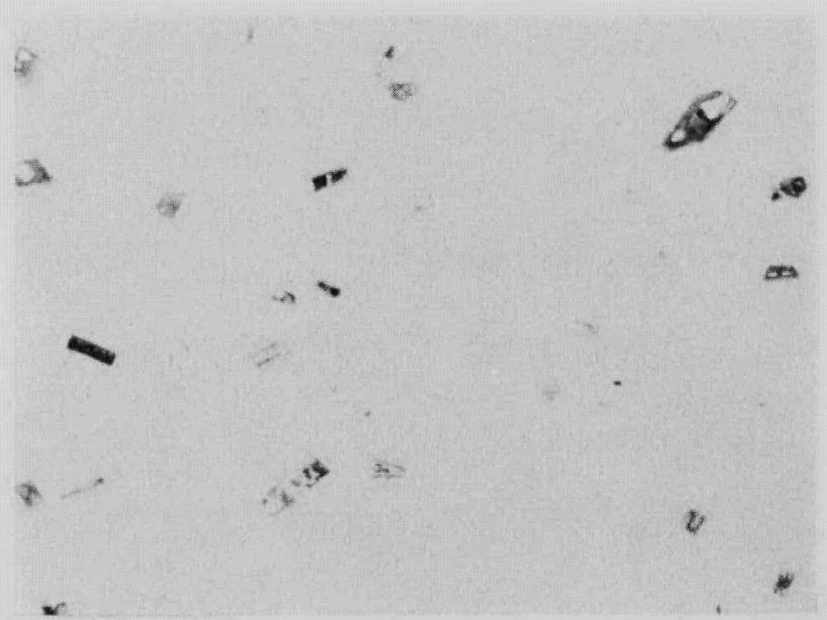

Figure 21

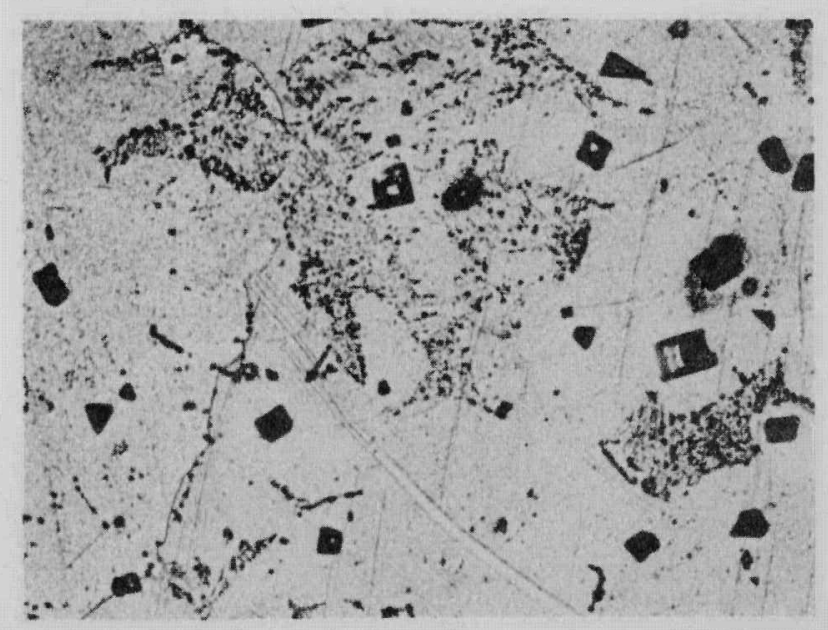

Micro 6345 Pollshed 100x Micro 7765 Etched $100 \mathrm{x}$ Anguiar Carbide Inclusions in Center of Angular Inclusions and Precipitate in Ingot.

$\because: \because \div \quad \because \because \because$ : Rotition and of Ingot.

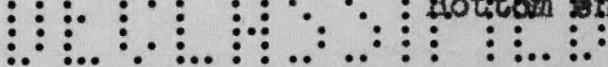


76

Figures 22 to 27. Microstructire of Uranium Liquated in Magnesia Crucible (Table II).

Pigure 22

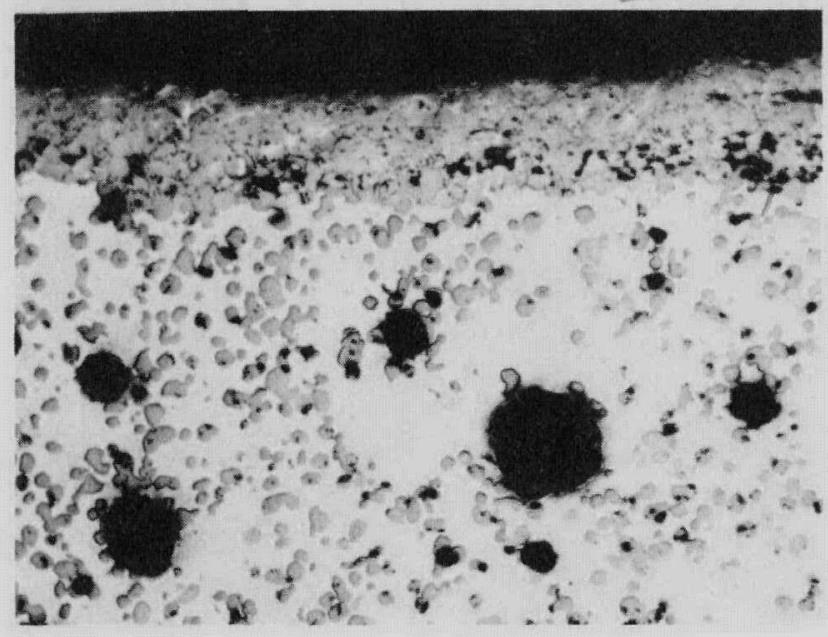

Figure 23

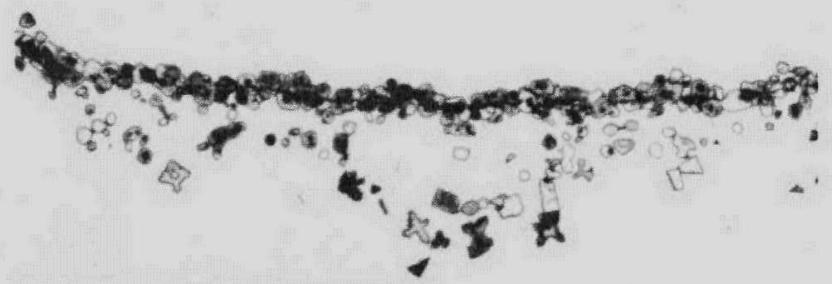

Micro 6358 Polished 100x $(B-2-T)$ FIIm in Liquated Hanford Metal.

Pigure 25

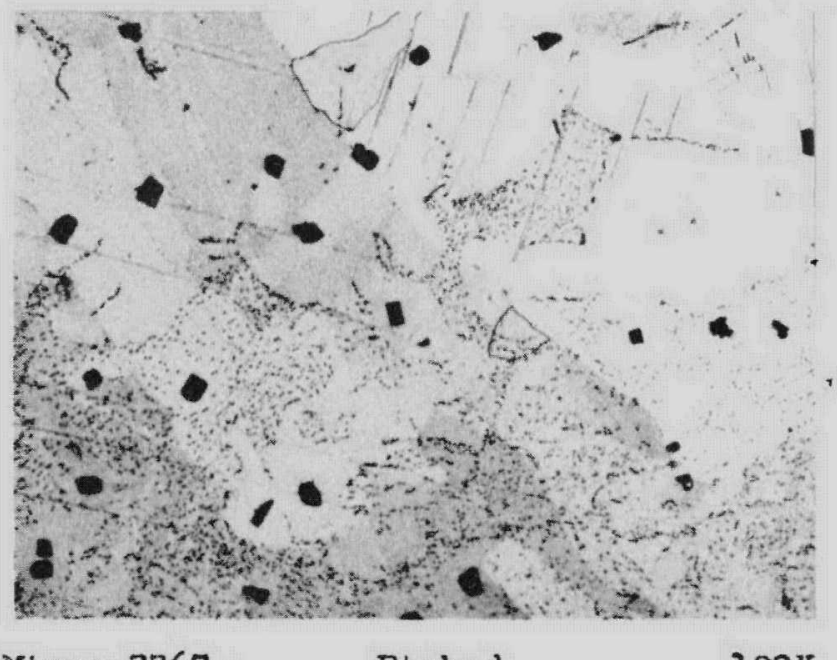

Micro 6360 Pollshed I00X $(B-2-T)$ Inclusions in Liquated Hanford Motal.

\section{Figure 26}

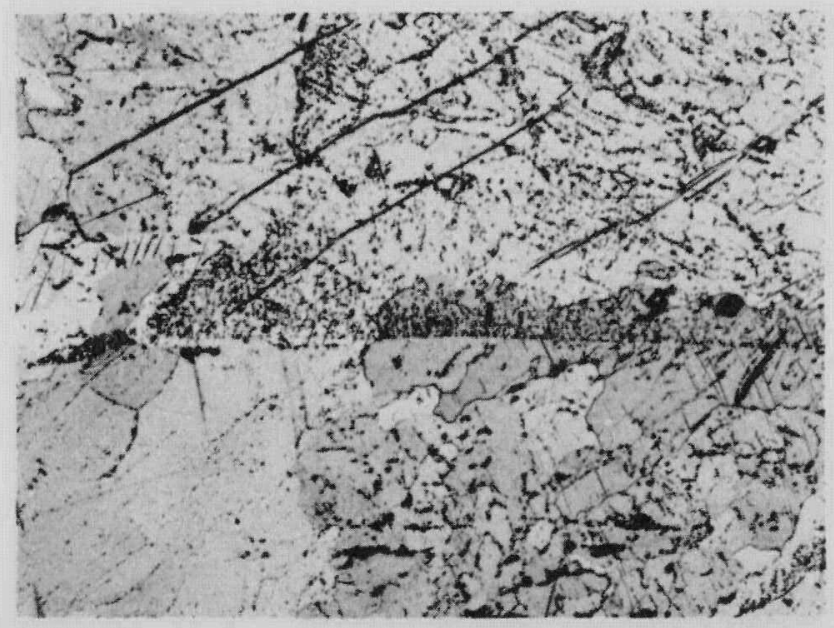

Hero 7767 Etched $100 \mathrm{x}$ $(B-2-T)$ Precipitate in Ifquated Hanford Netal.

Pigure 27

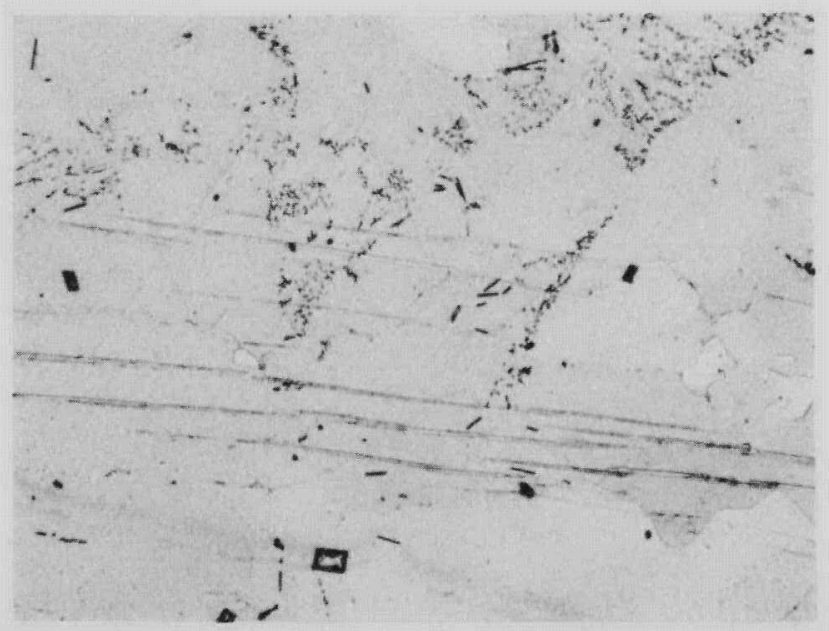

\section{Micro $7768 \quad$ Btched}

$(B-20-T)$ Heavy Precipitate $\ldots \ldots$...
Yicro 7737.7 Etched Liquated B1scuit $(8-2)_{1}=$ ? Is:ècipitato in Liquated B1scuit Biscuit Motal. 
Figures 28 to 33. Ifiquations of Hanford Metal in Urania Crucible (Table III,

Figure 28

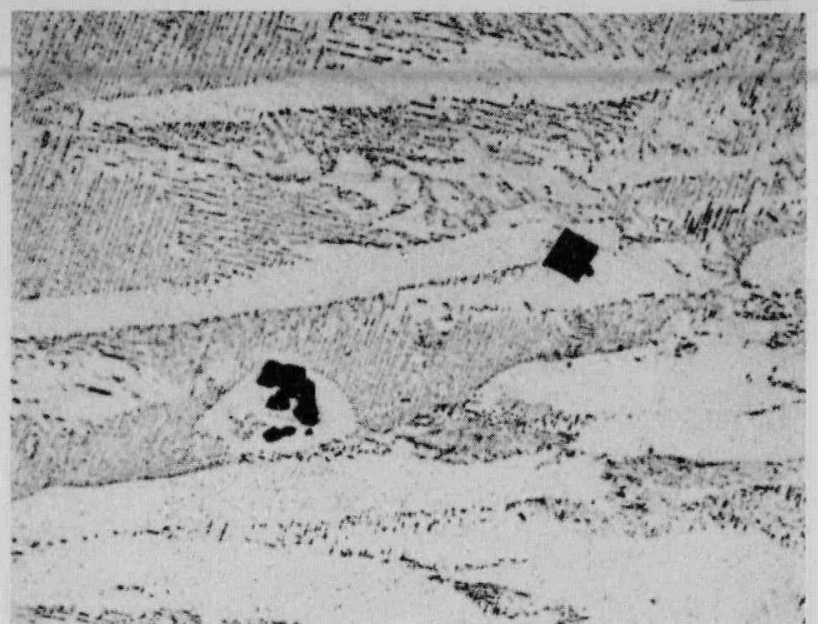

Micro 7840

Etched

$(B-96-B) \quad 24$ Hours Liquation in System Without Cold Trap.

Figure 30

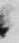

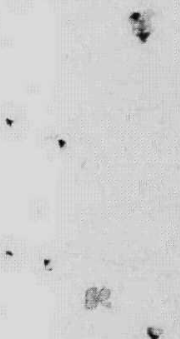

8

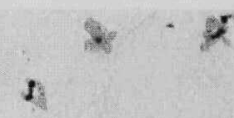

कर

Micro 16301 Polished

$(B-474-B) 24$ Hours Liquation of Hanford Metal in System with Cold Trap.

Figure 32

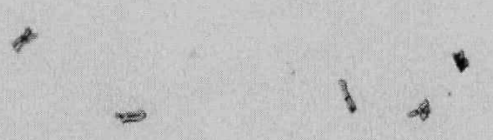

Micro 16299

Polished Micro 16299 Polished 100X

$100 \mathrm{x}$
Figure 29 Groups II and III).

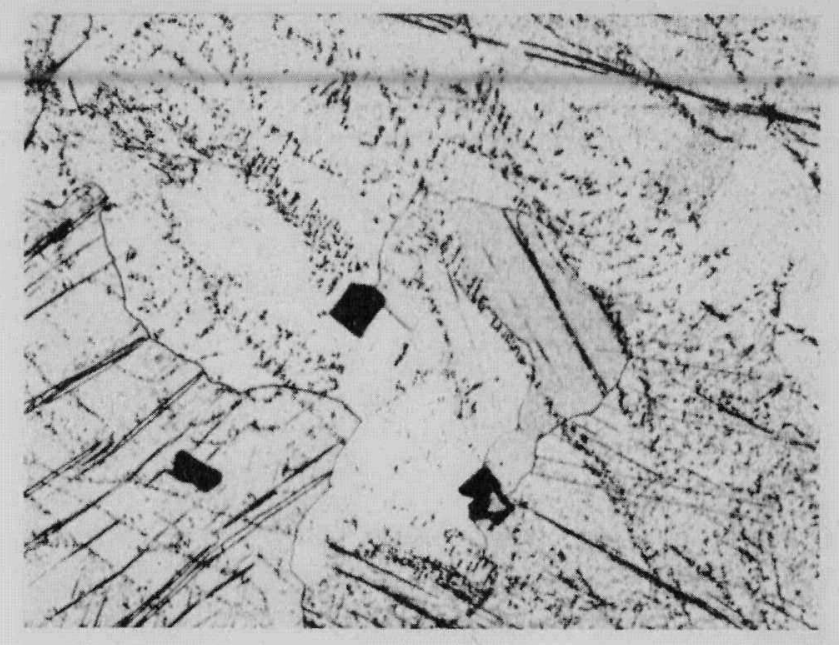

Micro 7719 Etched 100X

(B-83-B) 65 Hours Liquation in System Without Cold Trap.

Figure 31

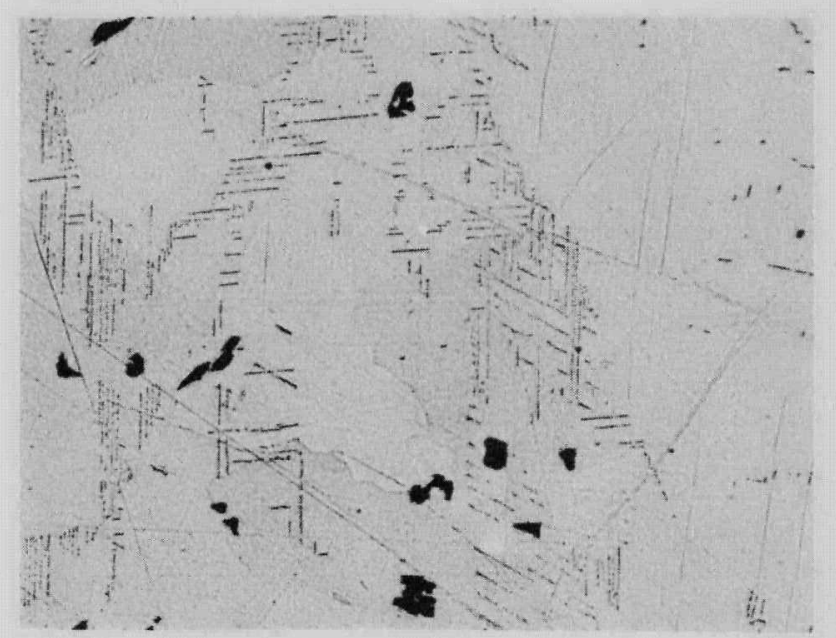

Micro 16302 Etched 100X (B-474-B) Same as Figure 30. Widmanstätten Pattern of Precipitate.

Figure 33

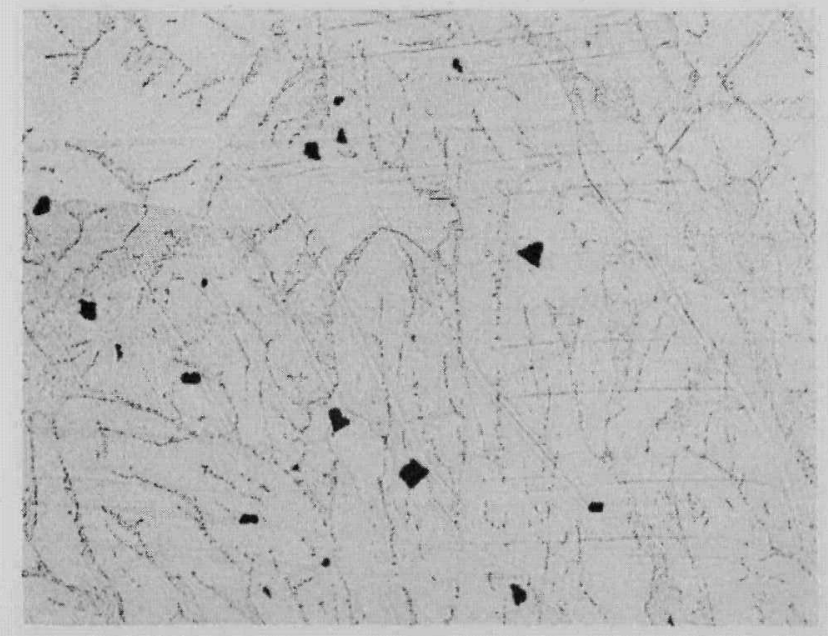


Figures 34 to 36. Liquations of Biscuit Metal in Urania Crucible. (Table III, Groups IV and V)

Figure 34

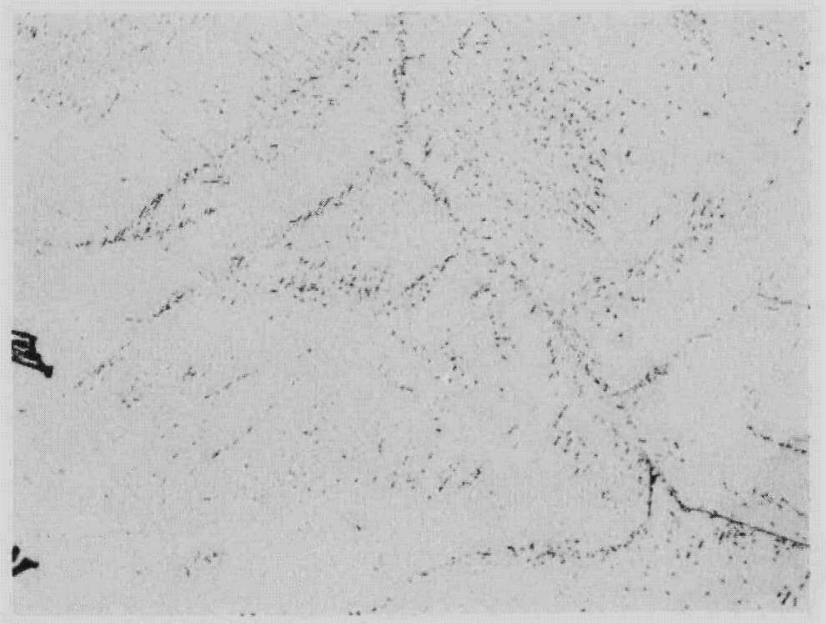

Micro $7455 \quad$ Etched

\section{Figure 35}

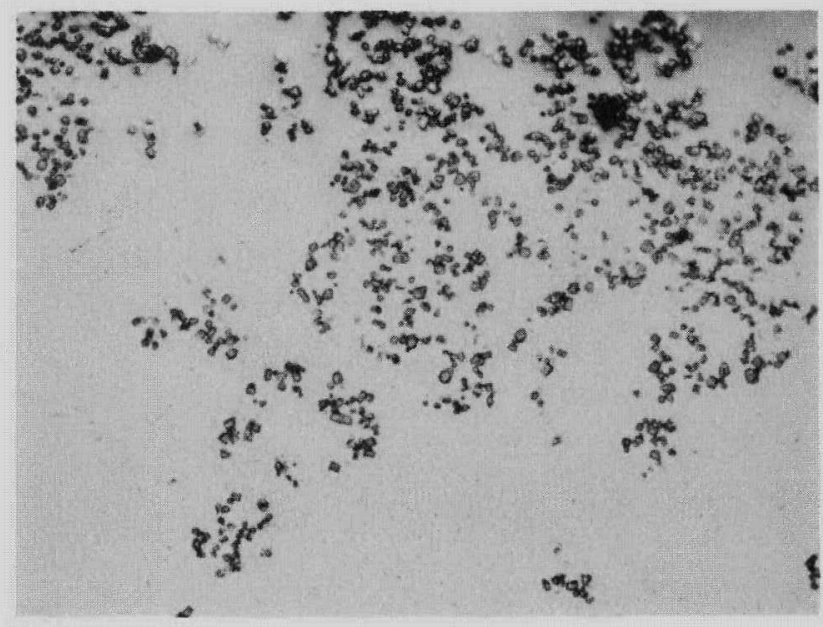

Micro 12350

Polishod

$100 x$ Without Cold Trap.

(B-68-B) Biscuit Metal Liquated in System $(\mathrm{B}-250-\mathrm{TL})$ Liquated Biscuit Metal.

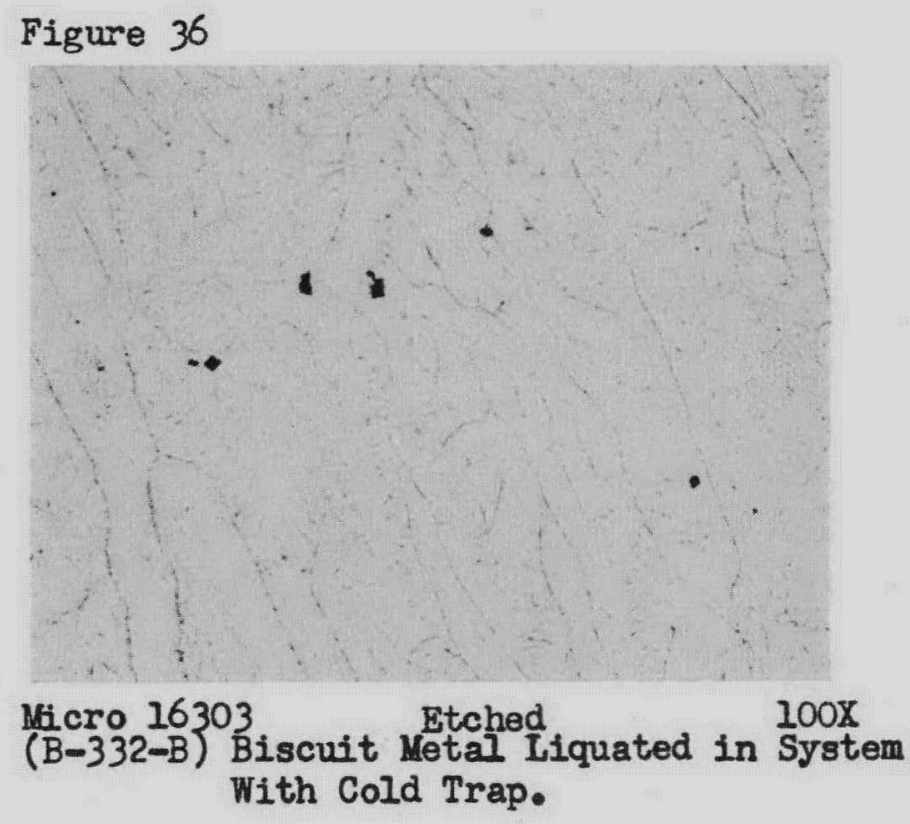



with Location and Carbon Content (Table IV)
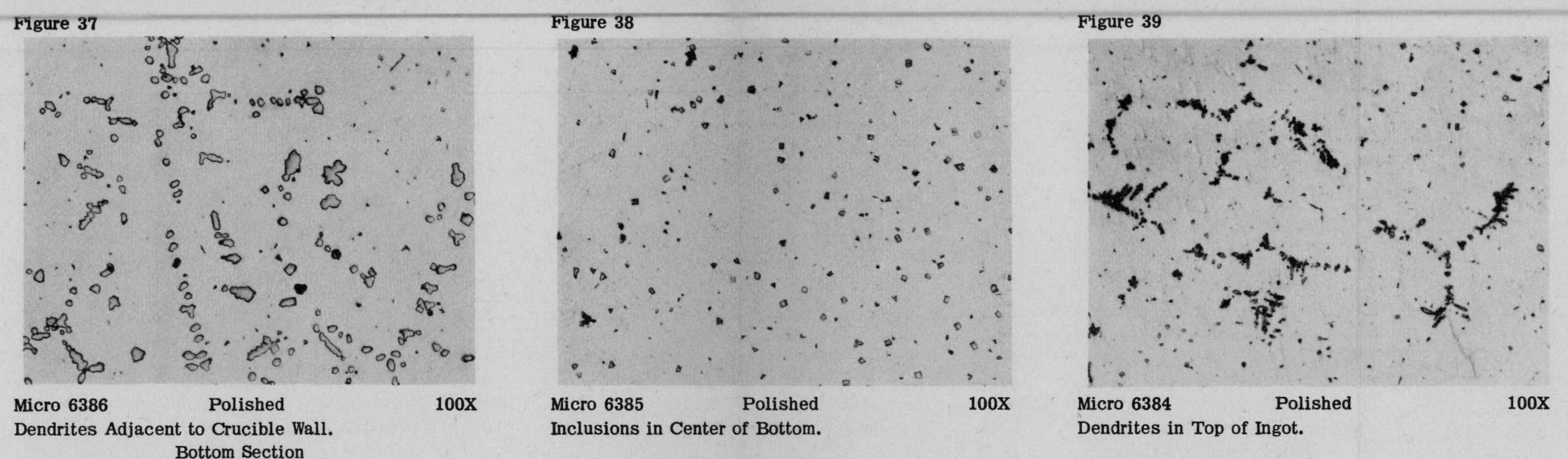

Ingot B-8
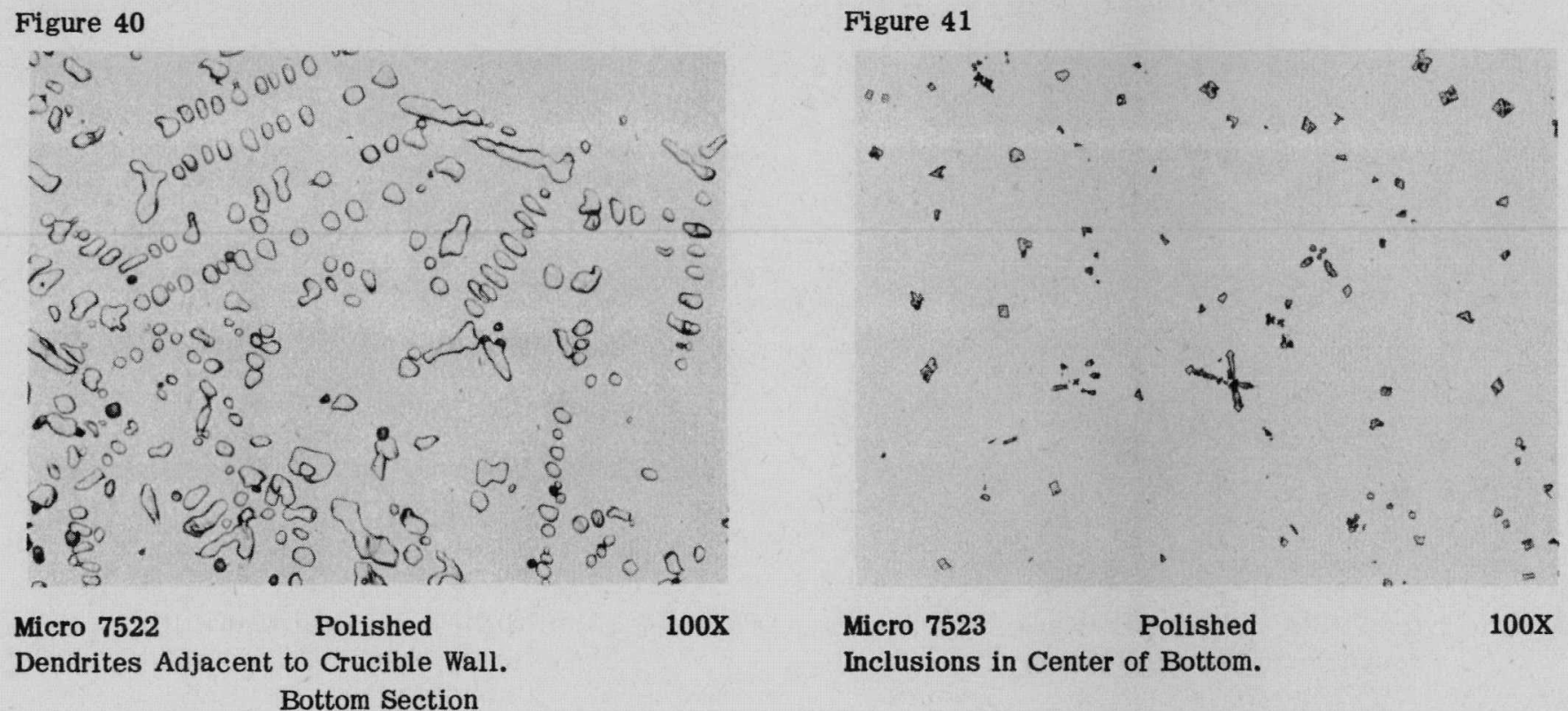

\section{Figure 42}

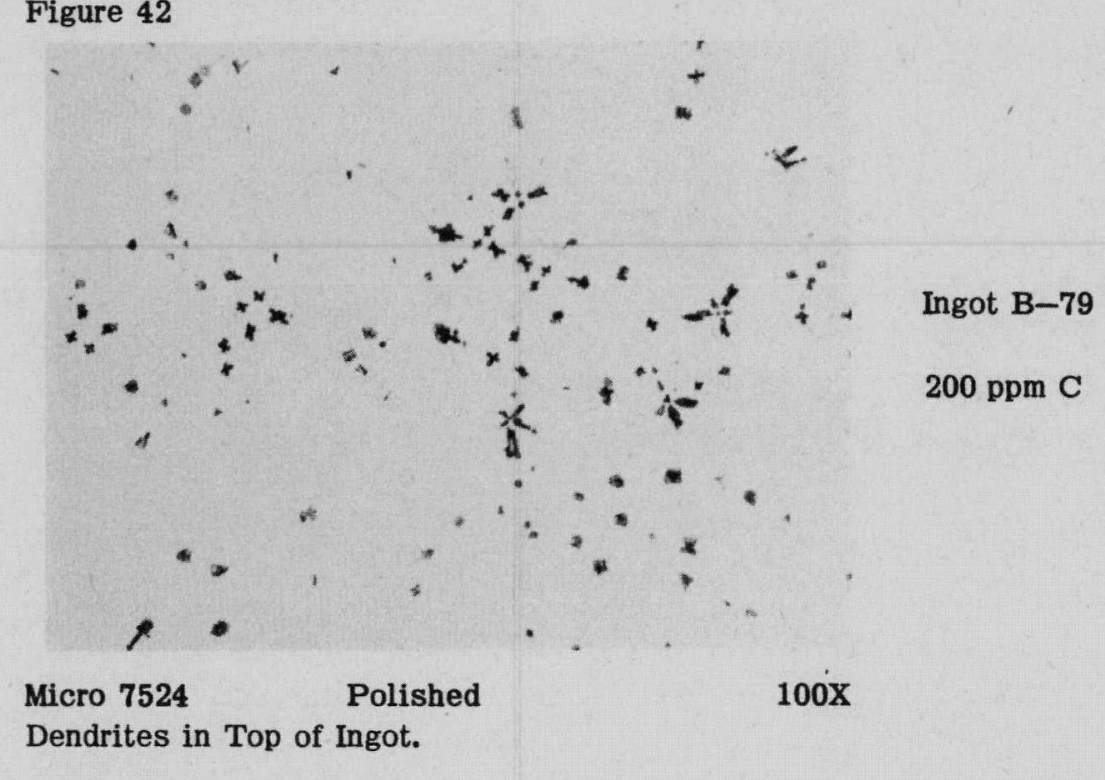

Figure 43

Figure 44

475 ppm C
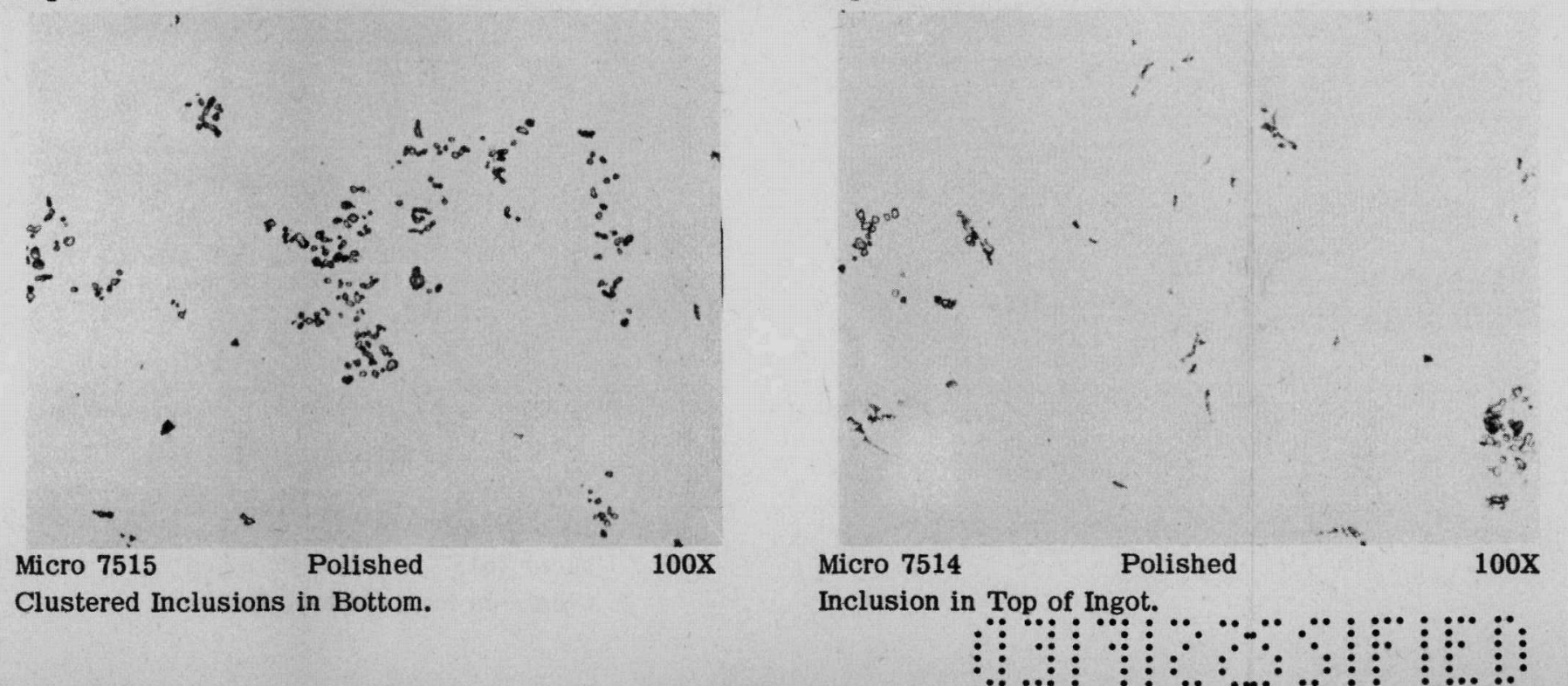

Ingot B-77

90 ppm C 
Micro $7516 \quad$ Polished 100X

Figures 46 to 49. Melts in Induction Furnace. Effect of Crucible Material (Table IV).

Figure 46

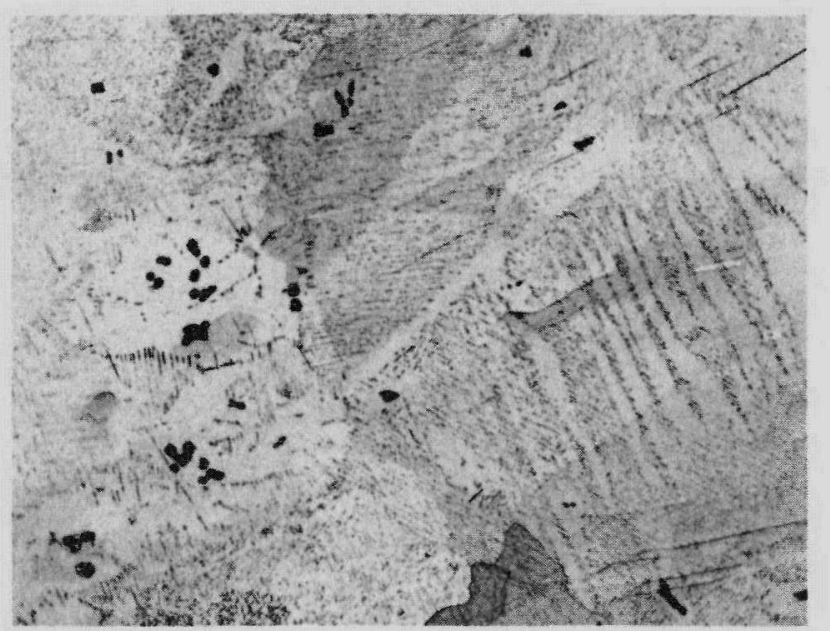

Micro $7513 \quad$ Etched 100X (B-77-B) Much Precipitate in Mgo Melted Ingot. Bottom Section.
Figure 47

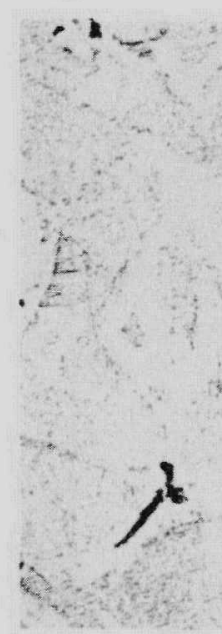

Micro 7512

(B-77-T) Much Precipitate in MgO Melted Ingot. Top Section.

Figure 48
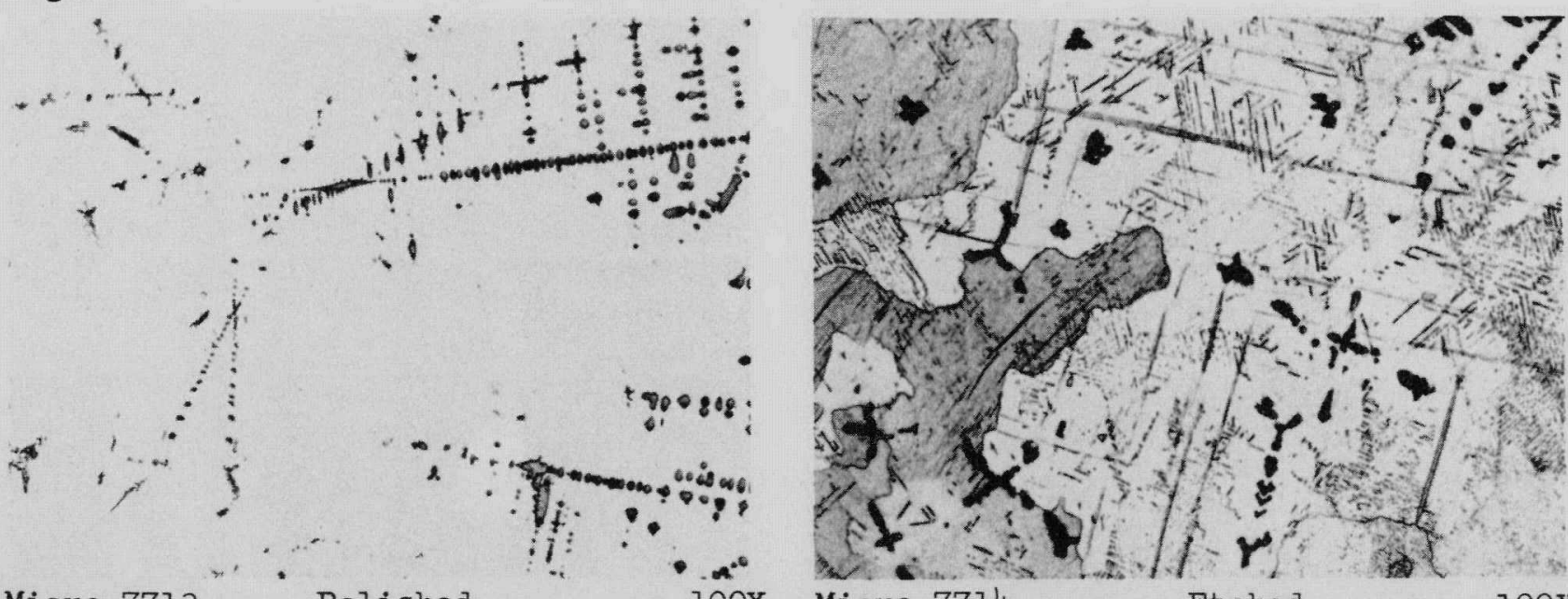

Micro 7713 Polished 100X Micro 7714

Etched

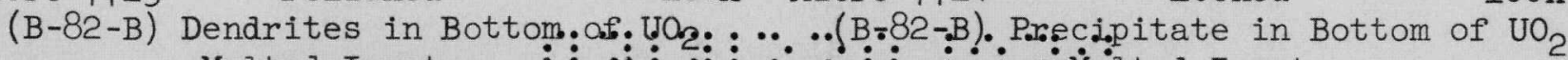
Melted Ingot. 
Figures 50 to 52. Melts in Helium and Hydrogen Atmosphere (Table V).

Figure 50

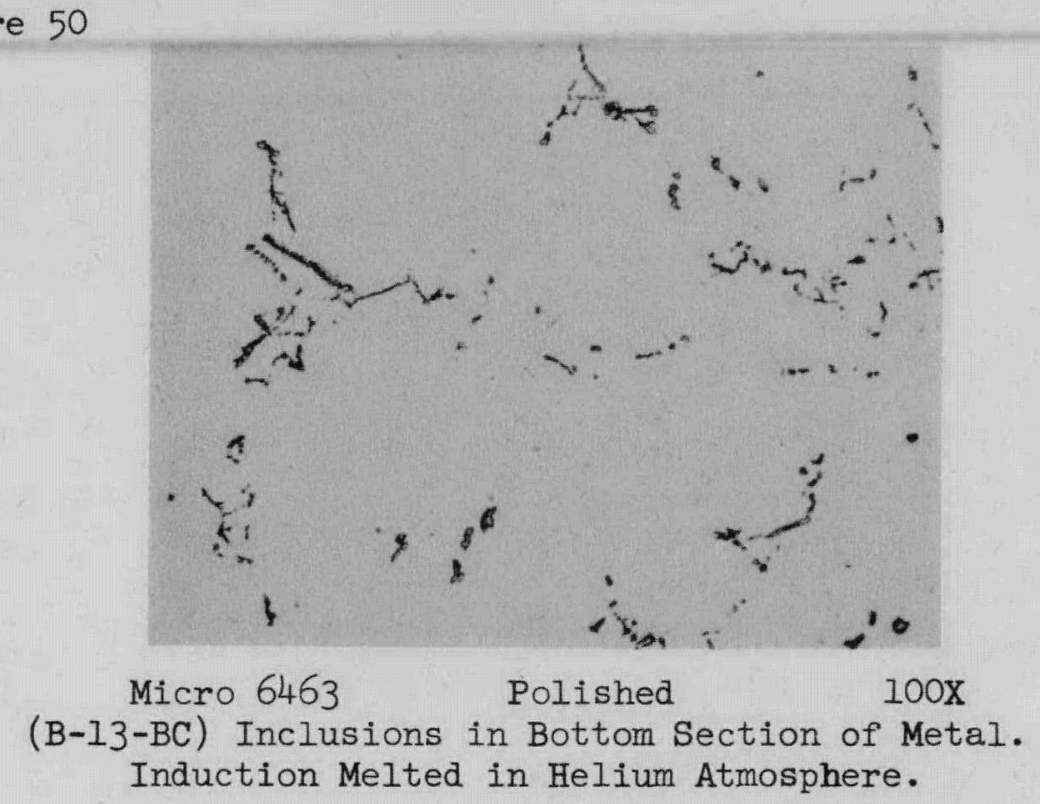

\author{
C: $470 \mathrm{ppm}$ \\ Fe: $200 \mathrm{ppm}$ \\ Si: $300 \mathrm{ppm}$
}

Figure 51

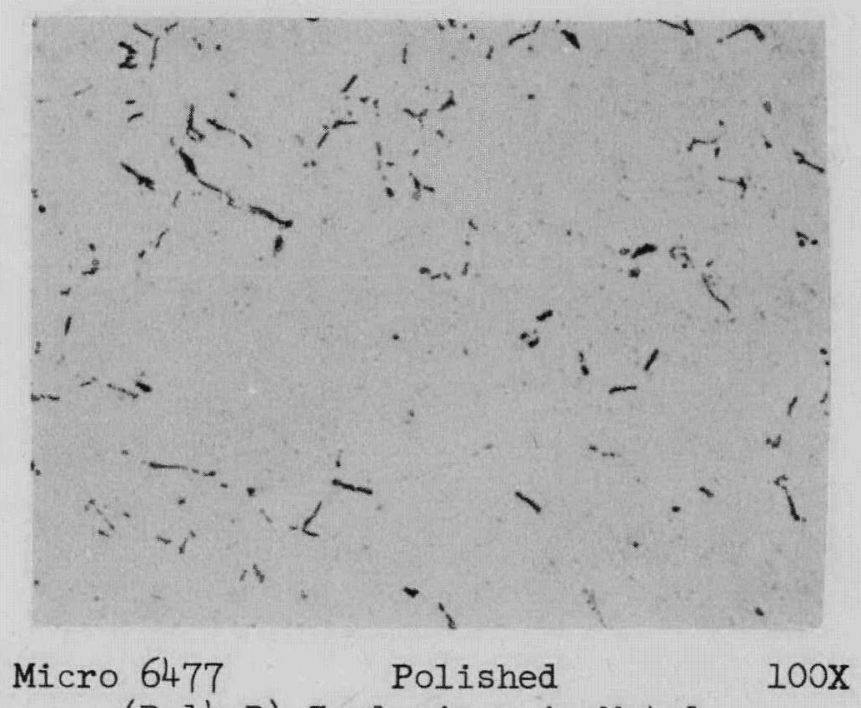

(B-14-B) Inclusions in Metal.

C: $470 \mathrm{ppm}$

Fe: $200 \mathrm{ppm}$

Si: $300 \mathrm{ppm}$

Induction Melted in Helium and Hydrogen Atmosphere.

Figure 52

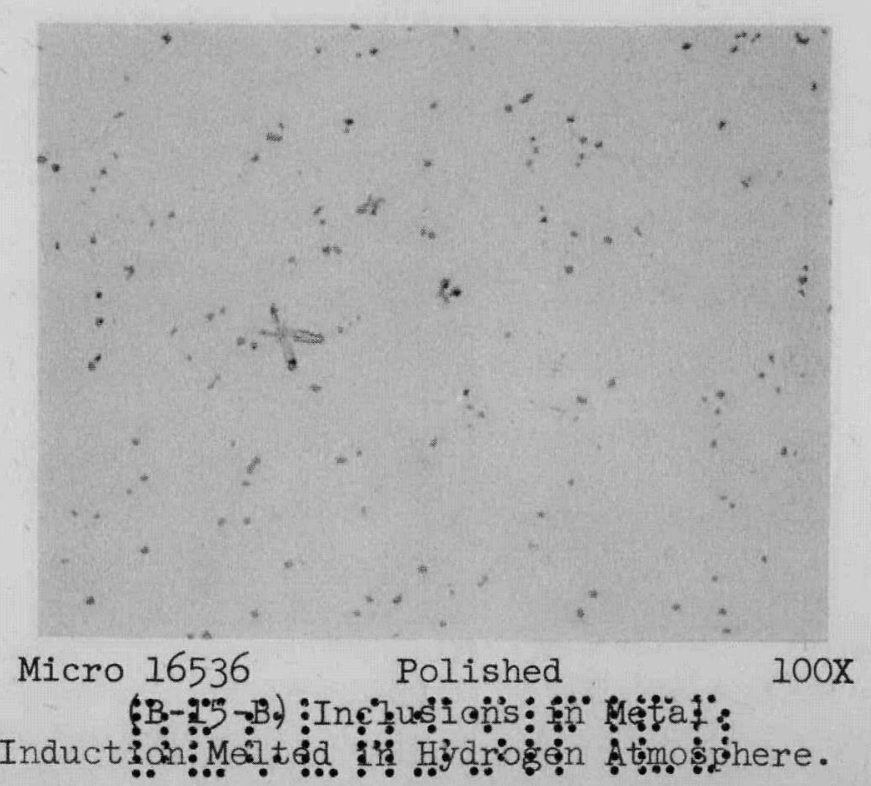

C: $470 \mathrm{ppm}$

Fe: $25 \mathrm{ppm}$

Si: $50 \mathrm{ppm}$ 
Figures 53 to 57. Melts in Tantalum and Alundum Crucible (Table VI)

Figure 53

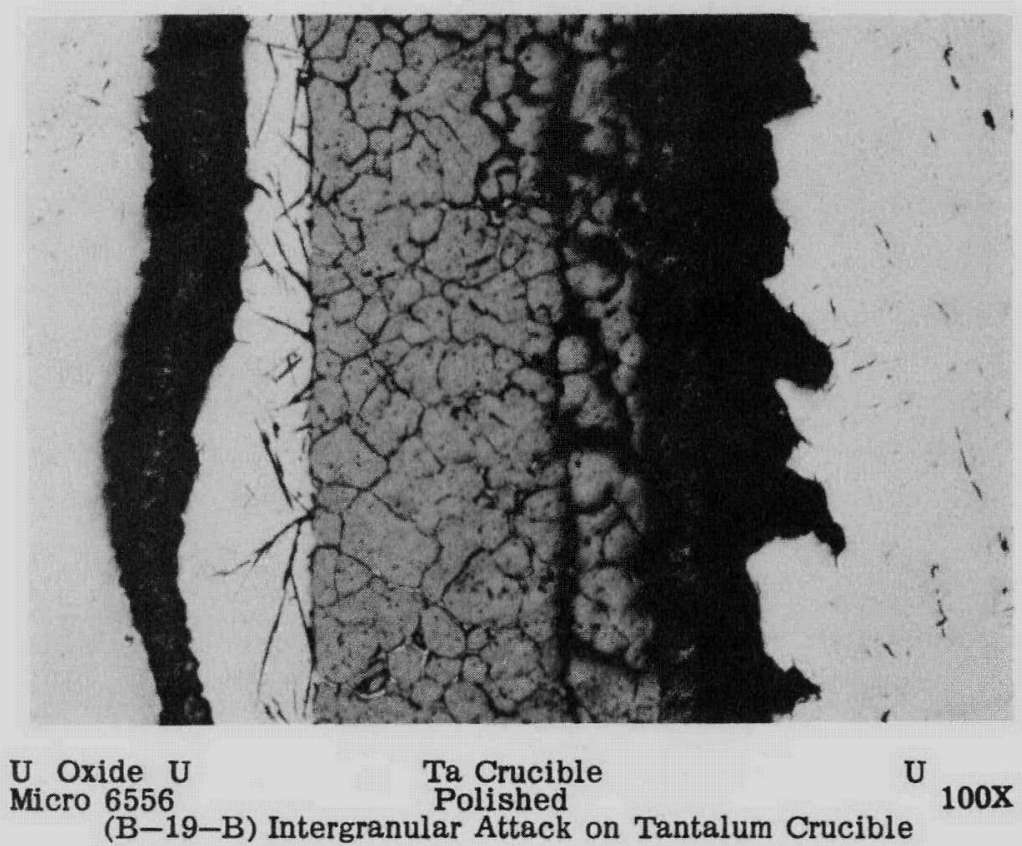

Figure 54

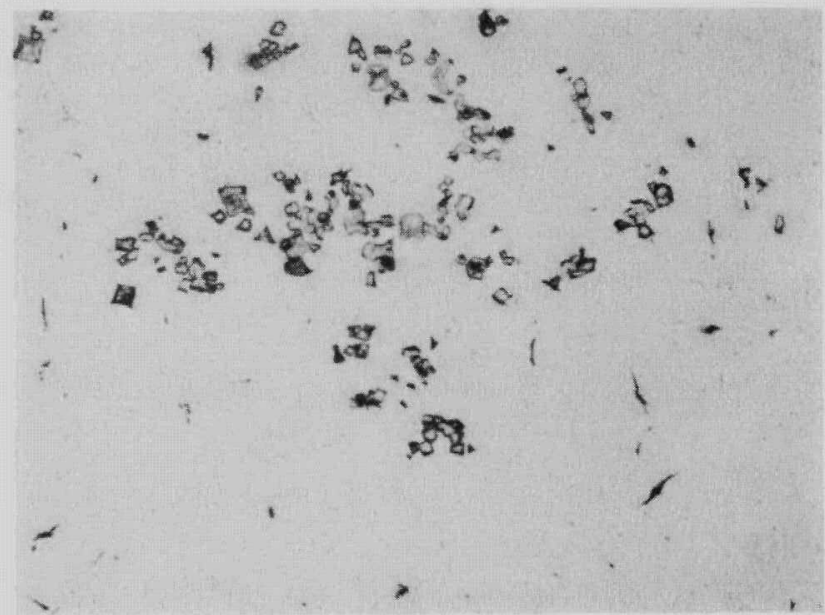

Micro 6559

Polished

$100 \mathrm{x}$

(B-19-T) Inclusions in Top of Uranium. Liquated in Tantalum Crucible.

Figure 56

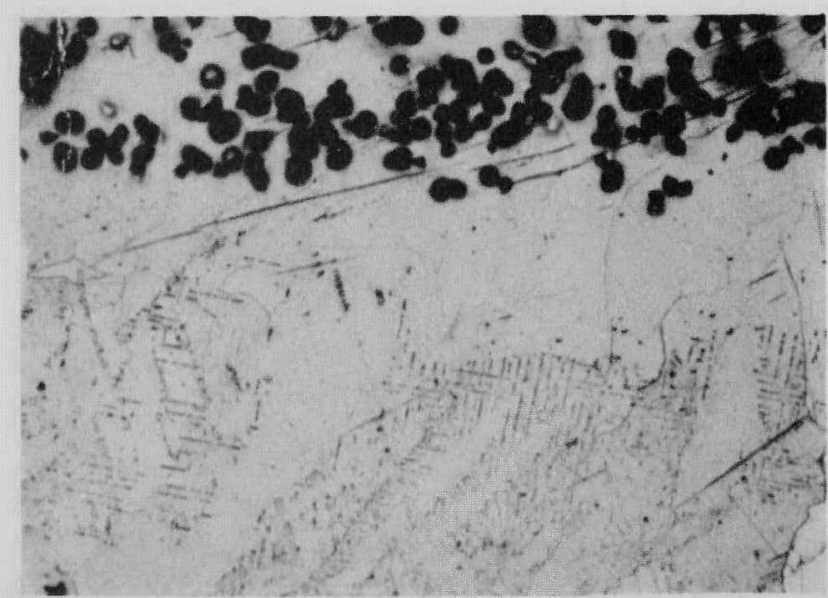

Figure 55

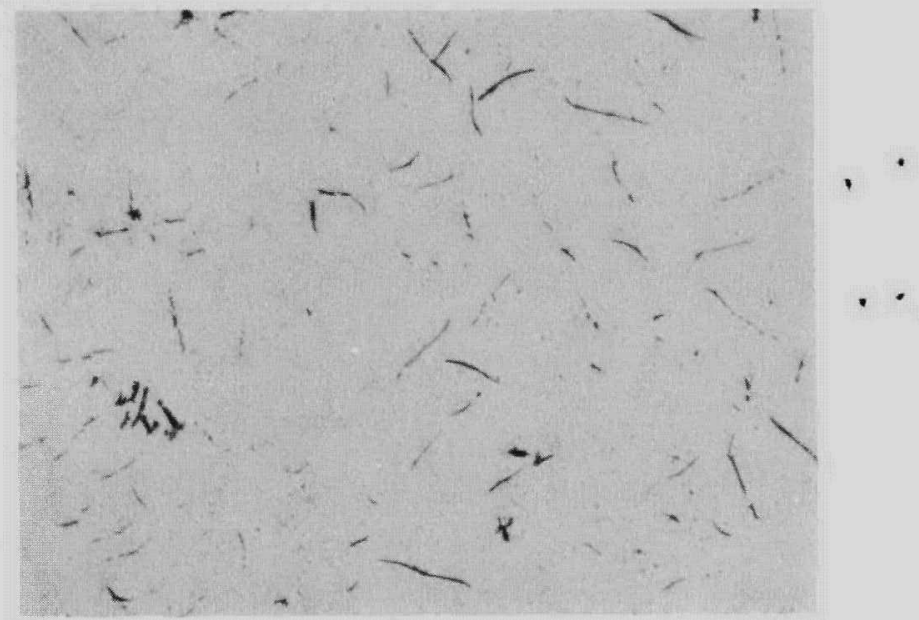

Micro 6555 Polished 100X (B-19-B) Flakes in Uranium. Liquated in Tantalum Crucible.

Figure 57

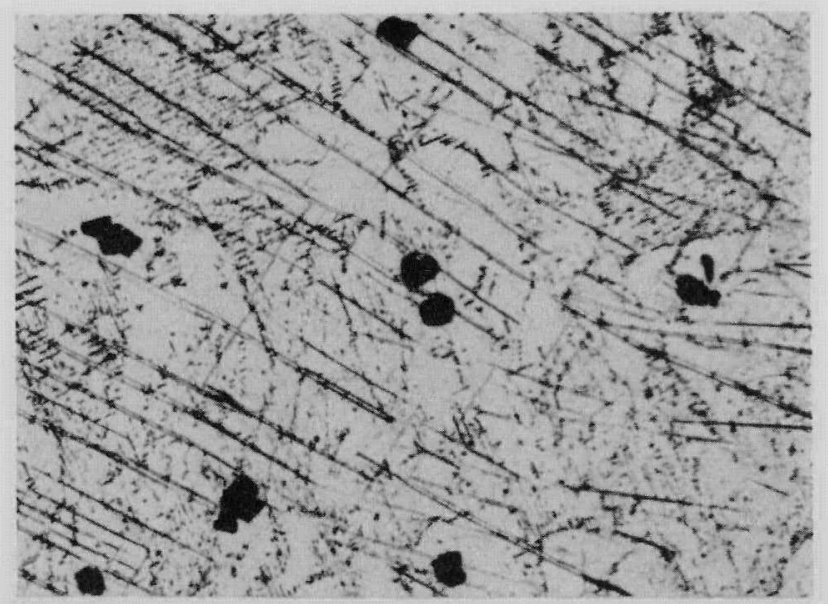


Figures 58 to 63. Melts in Calcia Zirconia and Titanium Carbide Crucibles (Table VI)

\section{Figure 58}

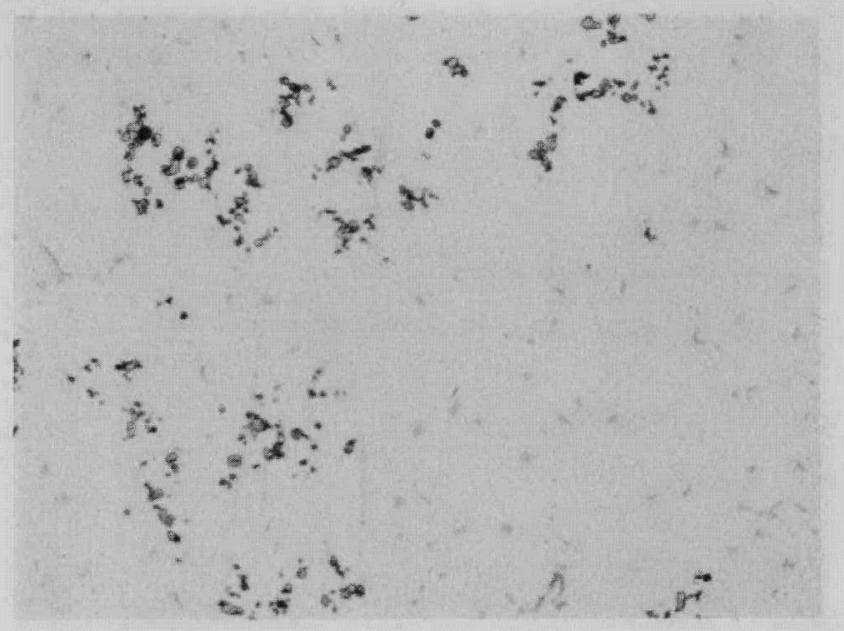

Micro $16304 \quad$ Polished

(B-108-B) Clustered Slag Inclusions in Metal Melted in Calcia Crucible.

\section{Figure 60}

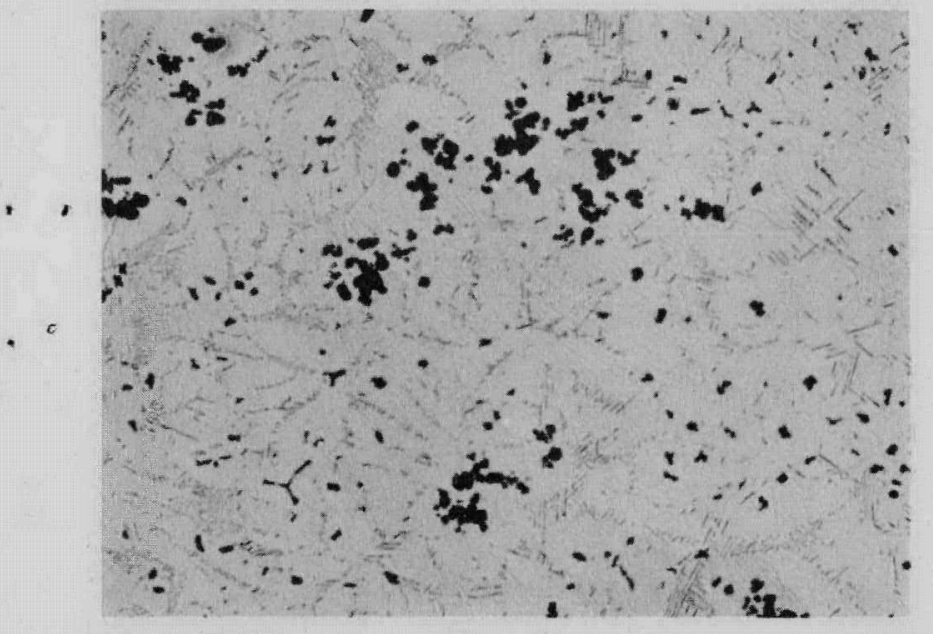

Micro $16306 \quad$ Etched

(B-108-B) Hanford Metal Melted in Calcia Crucible.

Figure 62

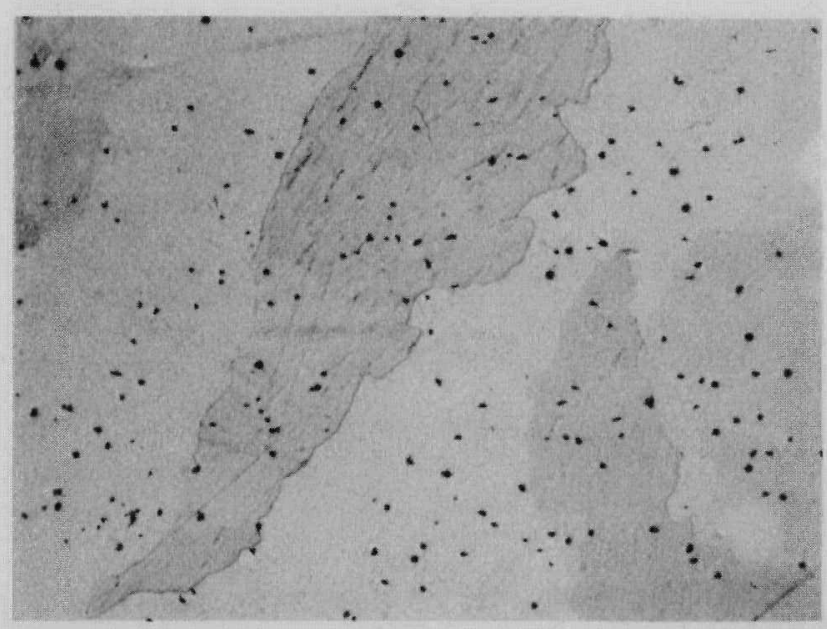

Micro $10449 \quad$ Etched 100X
Figure 59
\&.

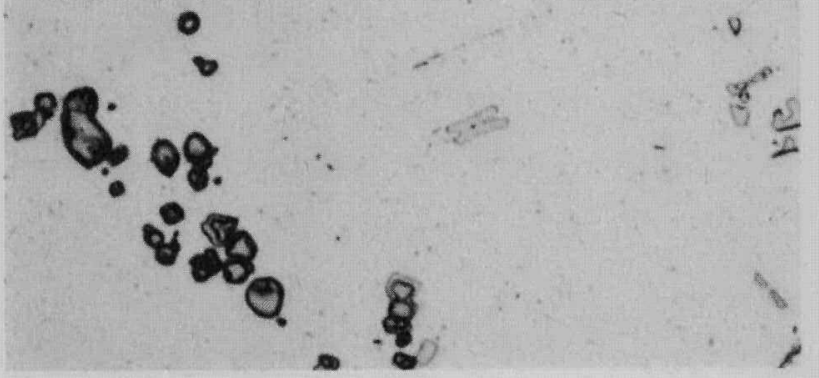

Micro 16305 Polished $100 \mathrm{X}$ (B-108-B) Slag and Carbide Inclusions in Metal Melted in Lime Crucible.

Figure 61

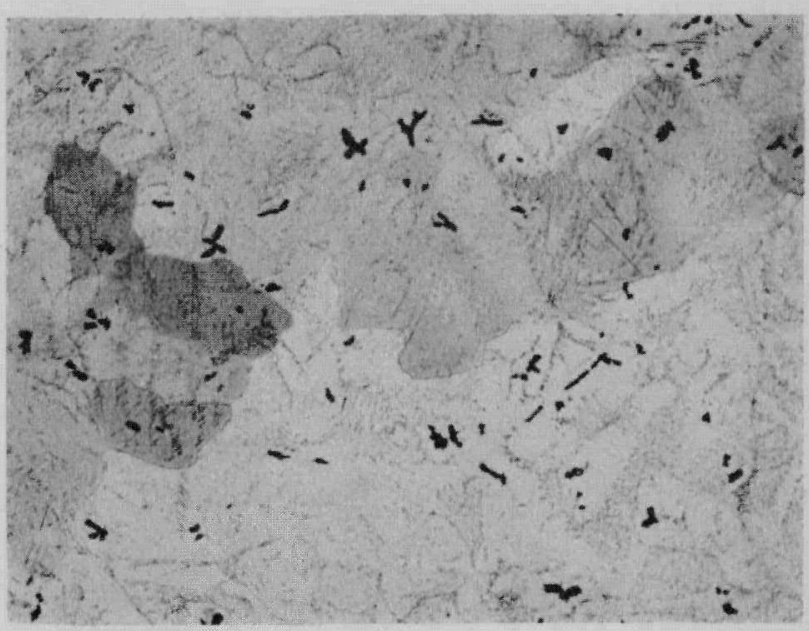

Micro $11038 \quad$ Etched $100 \mathrm{X}$ (B-113) Hanford Metal Melted in Zirconia Crucible.

Figure 63

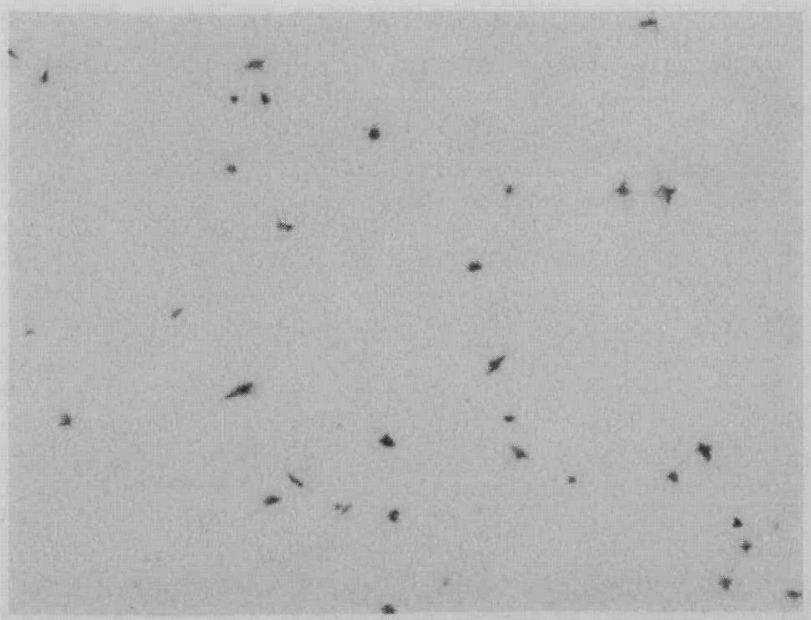

Micro $10448 \quad$ Polished 250X (B-153). Inclussions in Metal Shown in Figure 62. 


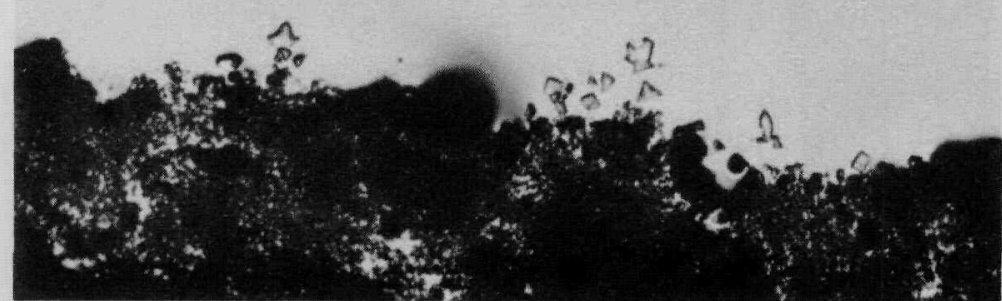

Micro 7248

\section{Polished}

(B-41-B) Groups of Nitrides Entering Melt. N content of Bottom Section Above Bottom Layer - $46 \mathrm{ppm}$.

Figure 66

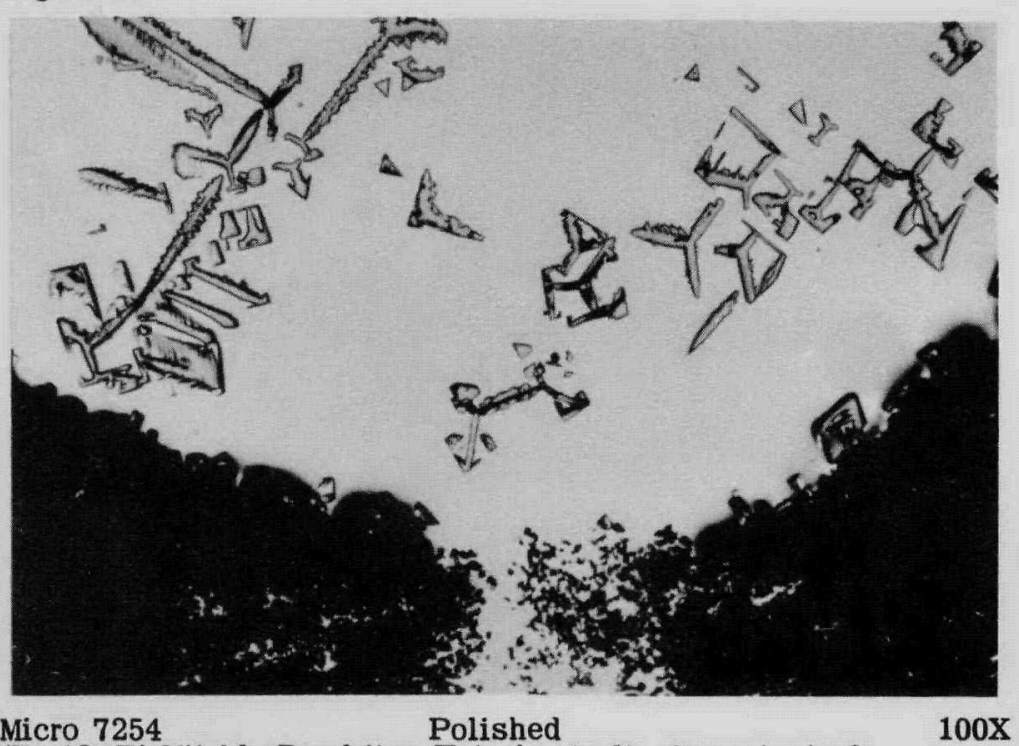

(B-42-B) Nitride Dendrites Entering Melt. N content of

100x

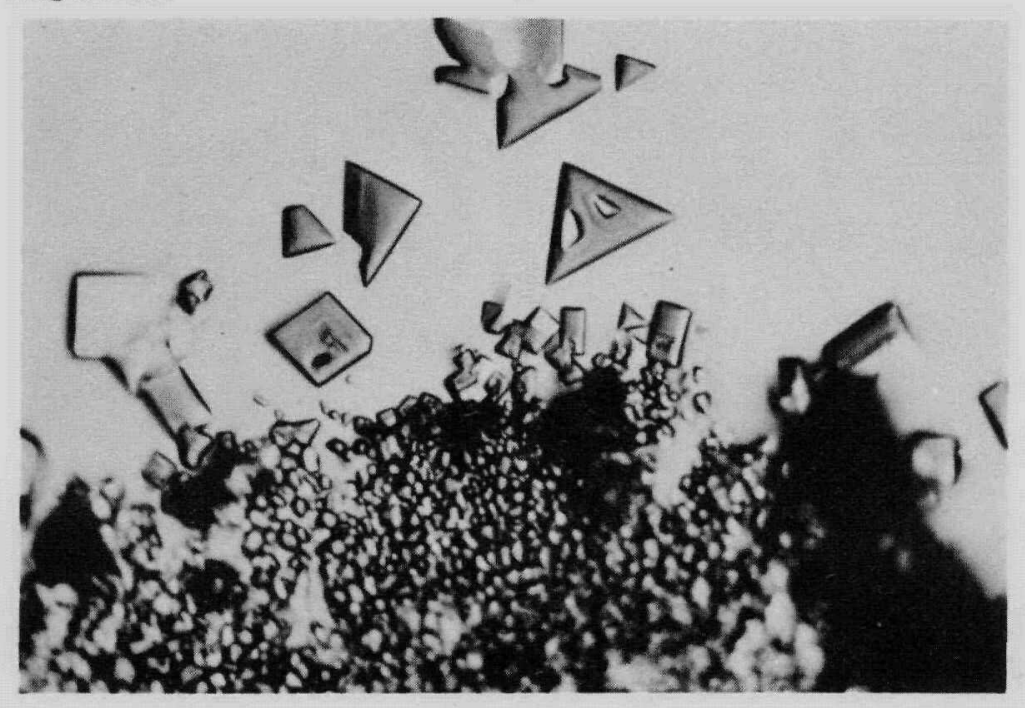

Micro 7249

Polished

(B-41-B) Same as Figure 58 at High Magnification.

$500 \mathrm{X}$

Figure 67

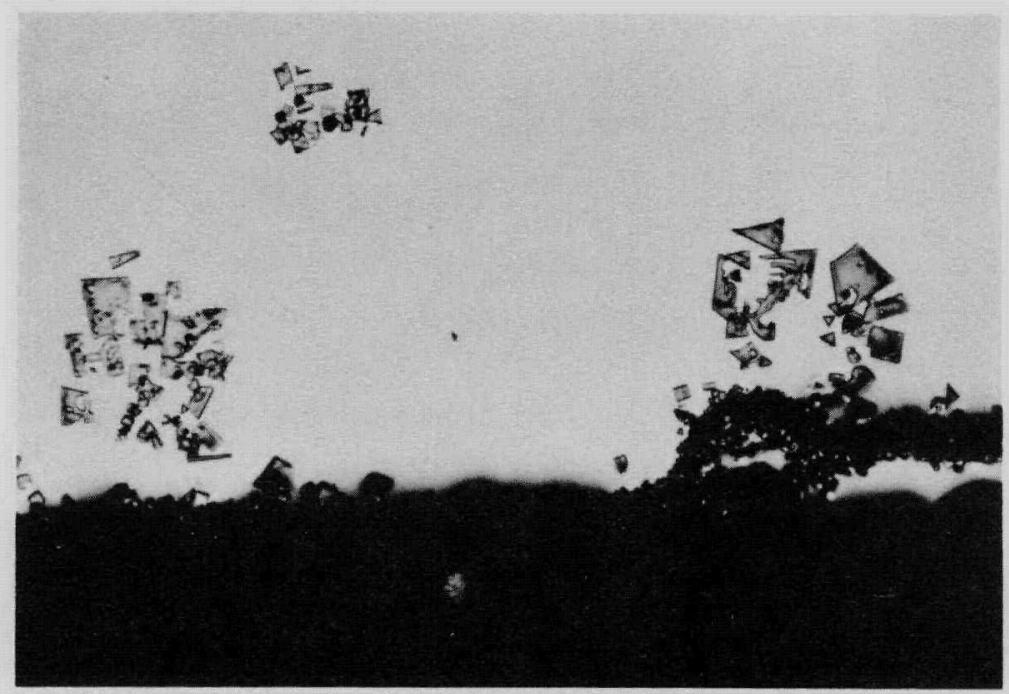
Polished
Micro 7288
(B-47-B) Nitride Cubes Still Entering Melt After 1 Hour in the Molten State. 
Figures 68 and 69. Redissolution of Nitrides.

Figure 68

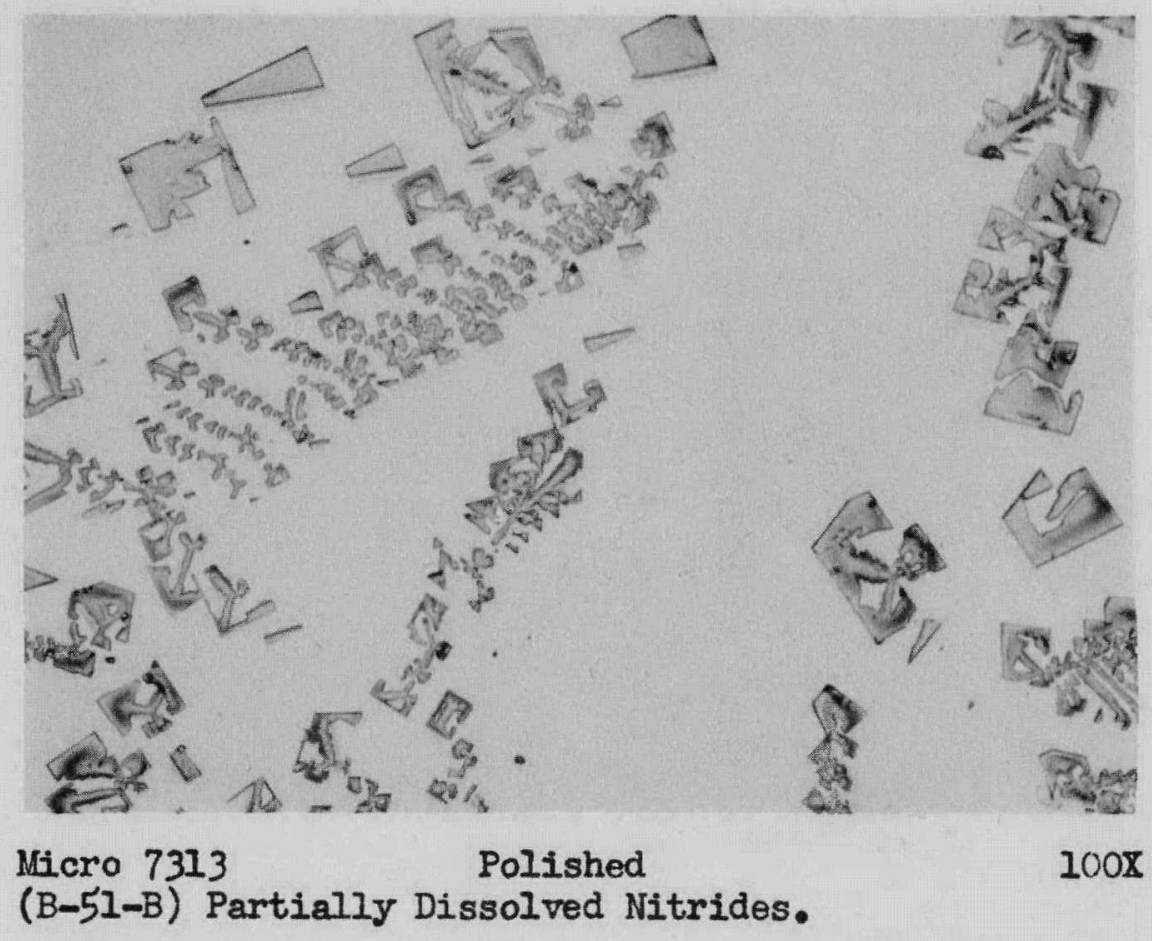

Figure 69
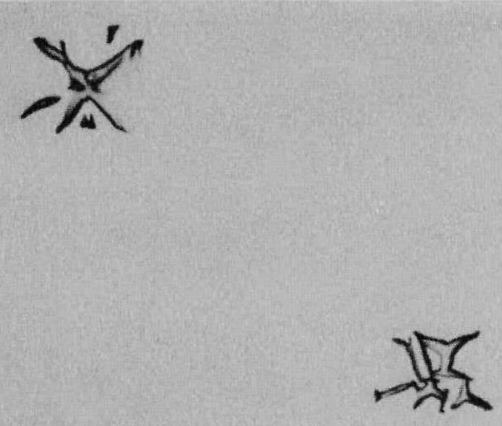

Micro 7291

Polished

$500 \mathrm{x}$ (B-47-B) Residual Forms of Partially Dissolved Nitrides. 
Figure 70

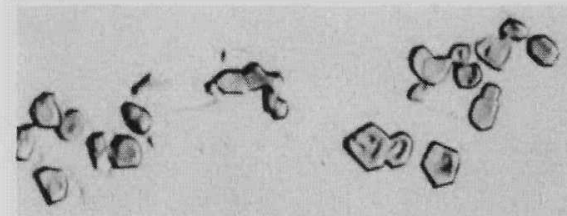

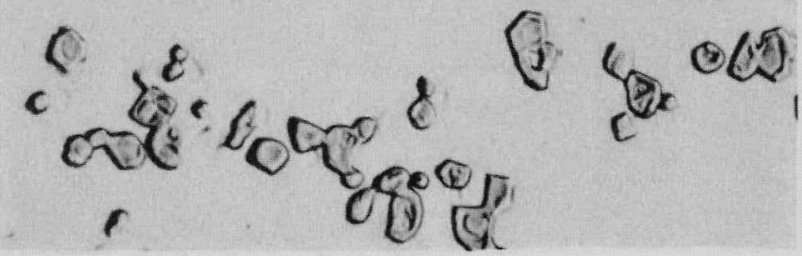

Micro 7238

Polished

$500 \mathrm{x}$

(B-37-B) The Nitrides as Angular Inclusions. (N: 230; C: $55 \mathrm{ppm}$.)

Figure 72

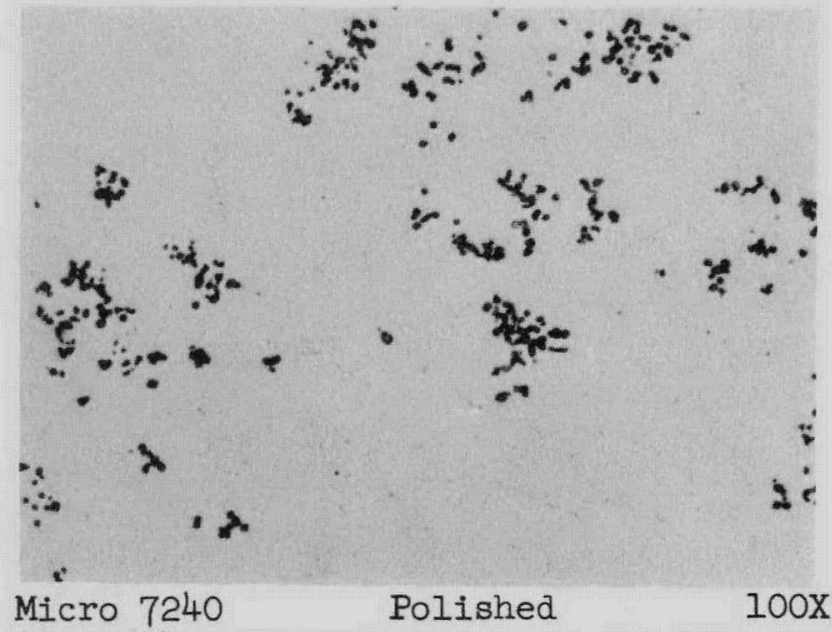

(B-37-T) Clustered Nitrides. N: 352;

C: $45 \mathrm{ppm}$. Same Ingot as Above.
Figure 71
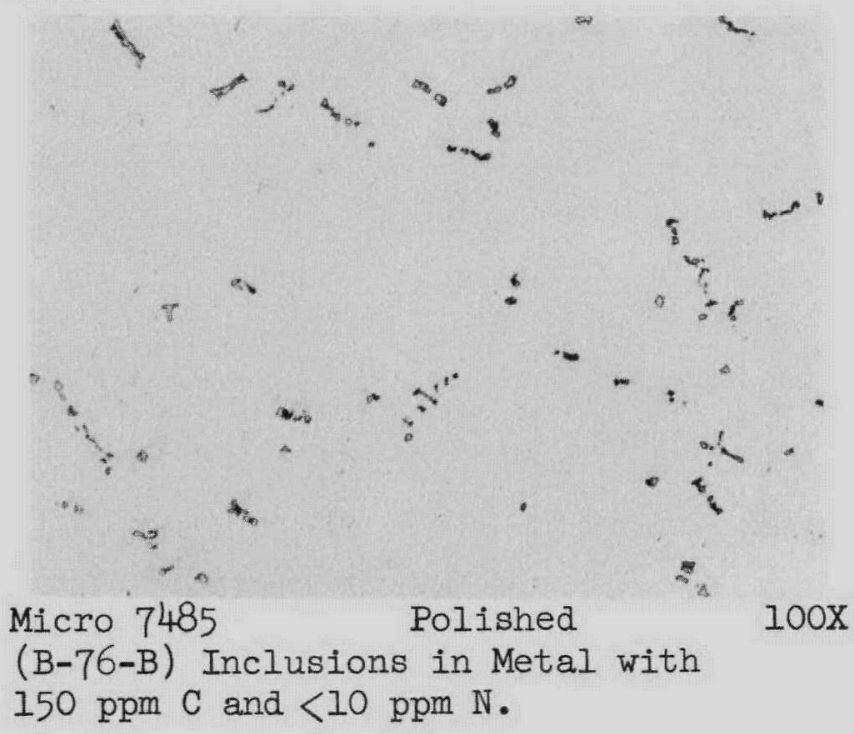

Figure 73

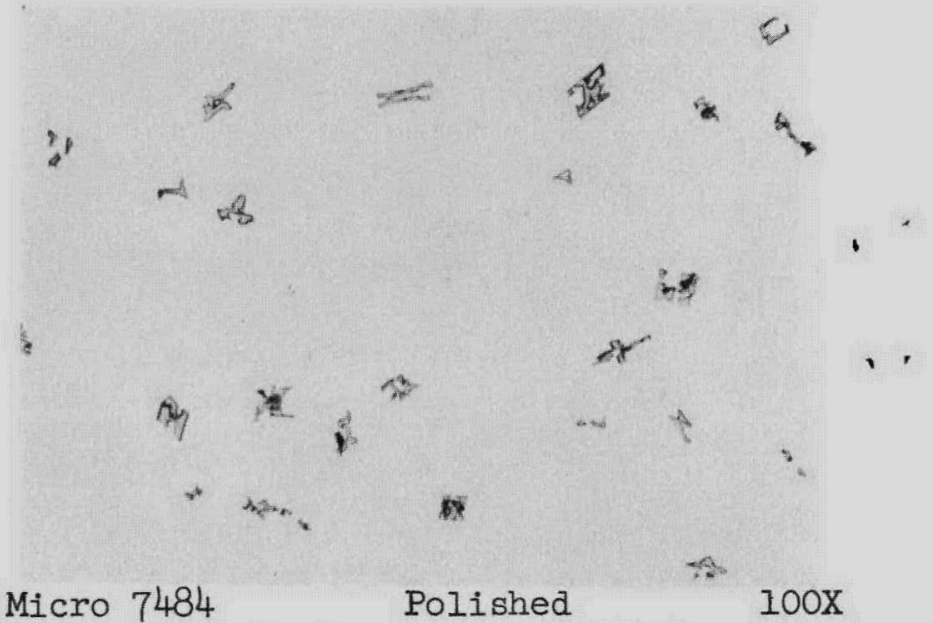

(B-76-T) Inclusions in Metal With

$65 \mathrm{ppm} C$ and $<10 \mathrm{ppm} \mathrm{N}$. Same Ingot as Above.

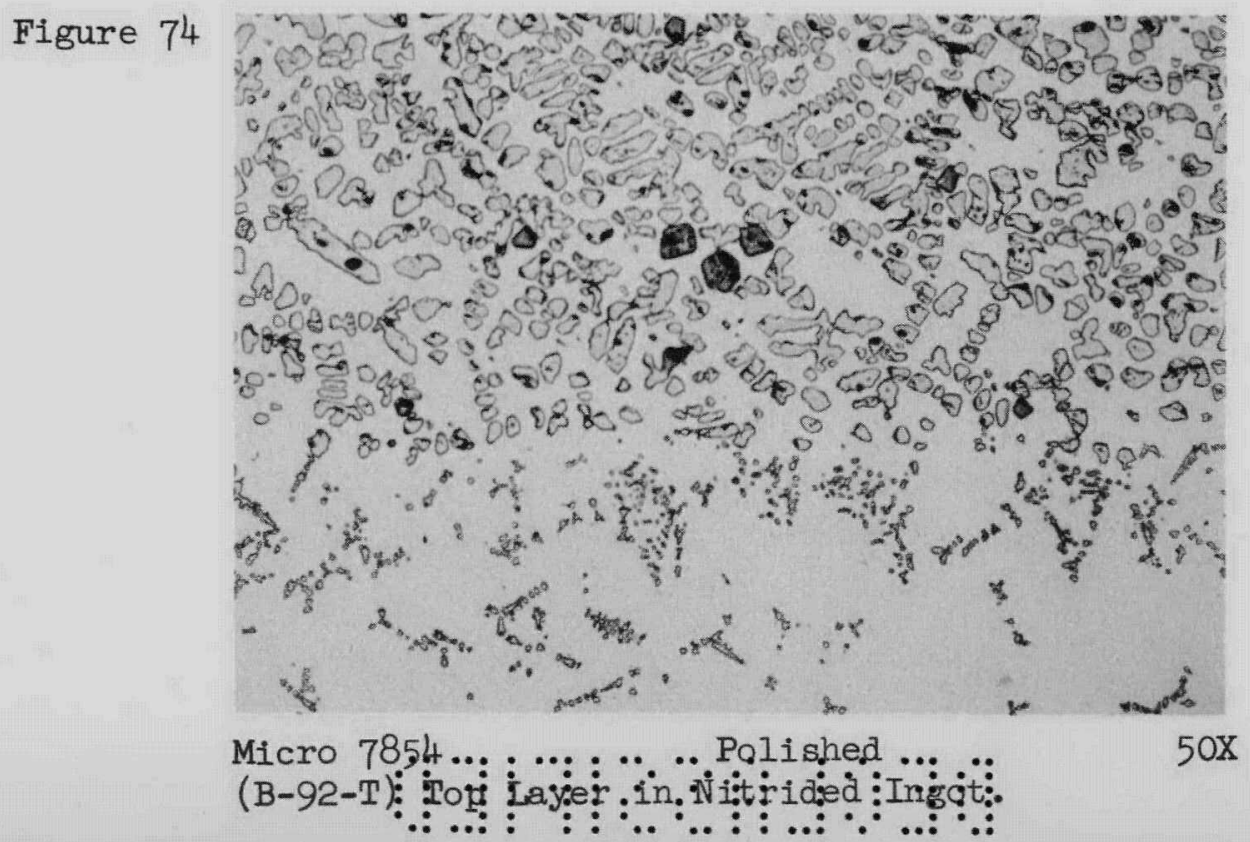


Figures 75 to 79. Precipitate in Metal Nitrided in MgO Crucible (Figure 79 in Urania Crucible)

Figure 75

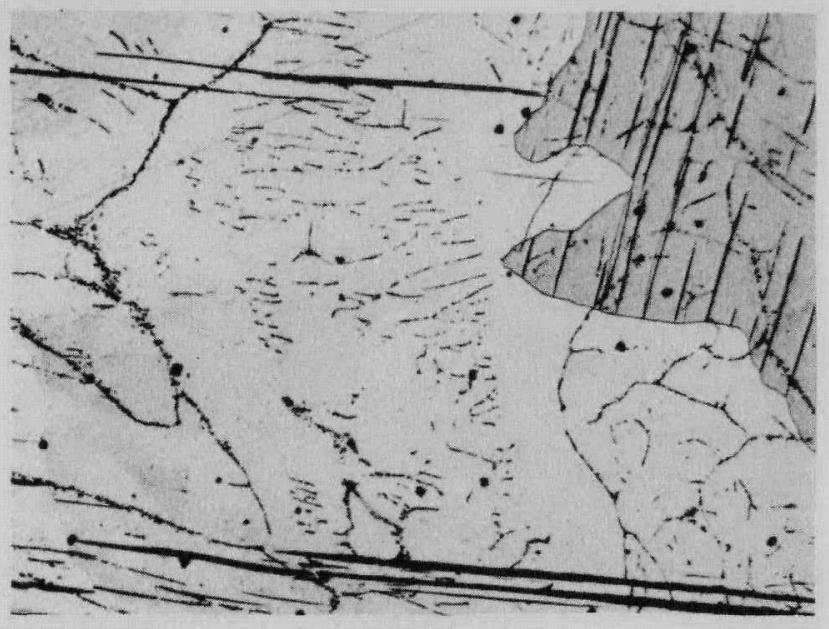

Micro 7771

Etched

$100 \mathrm{x}$
Figure 76

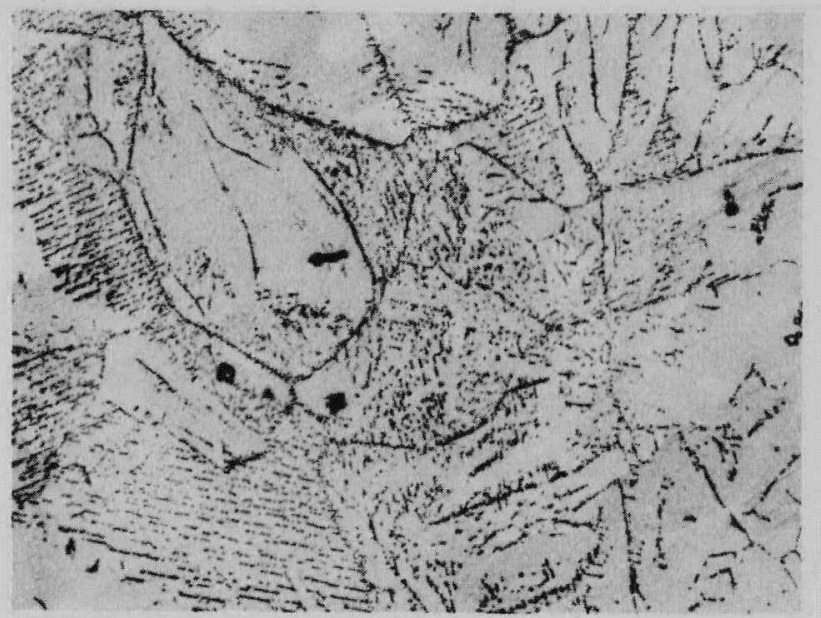

Micro 7770

(B-37-B) N: 230; C: 55 ppm.

$100 \mathrm{x}$

Figure 78

Figure 77

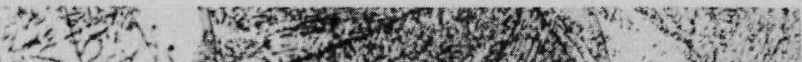

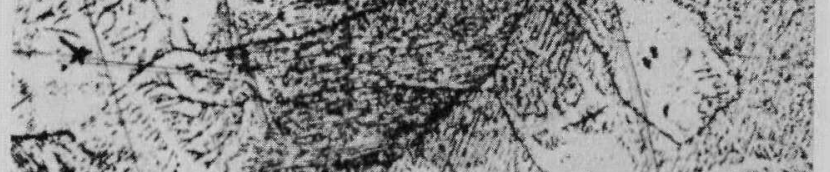
6. 6.t. 2. ${ }^{2}$ -

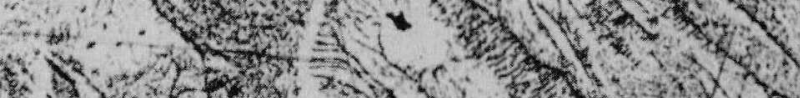

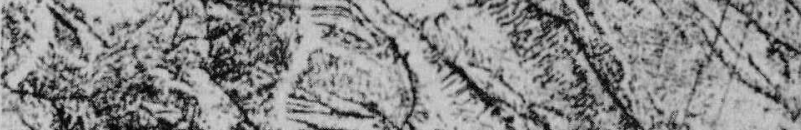

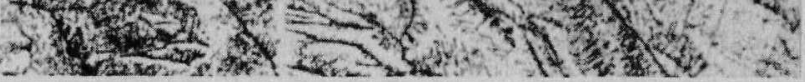
Micro 7773 Etched (B-48-B) N: 29 to 85 ; C: $26 \mathrm{ppm}$.
$100 \mathrm{x}$

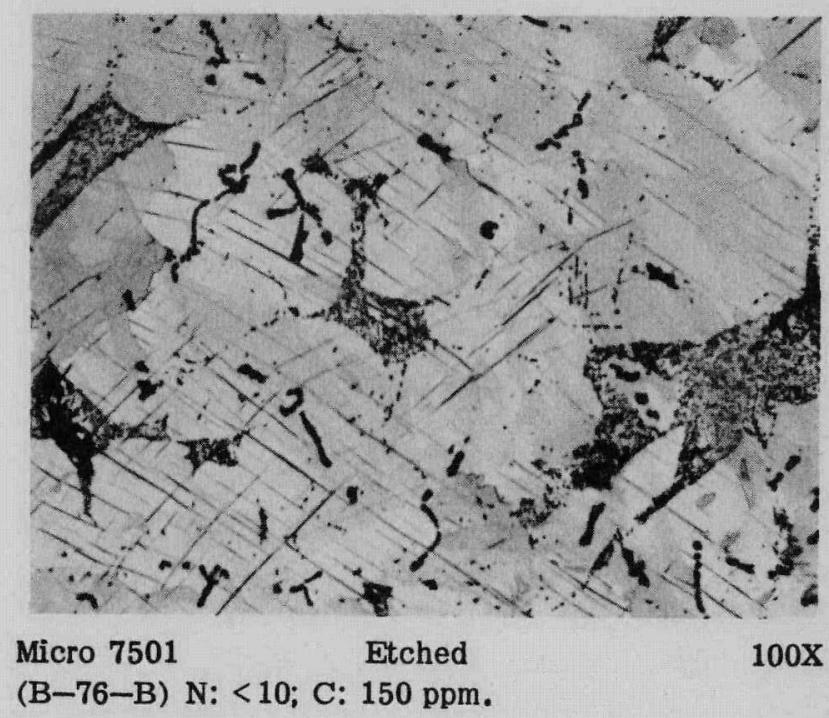

Figure 79

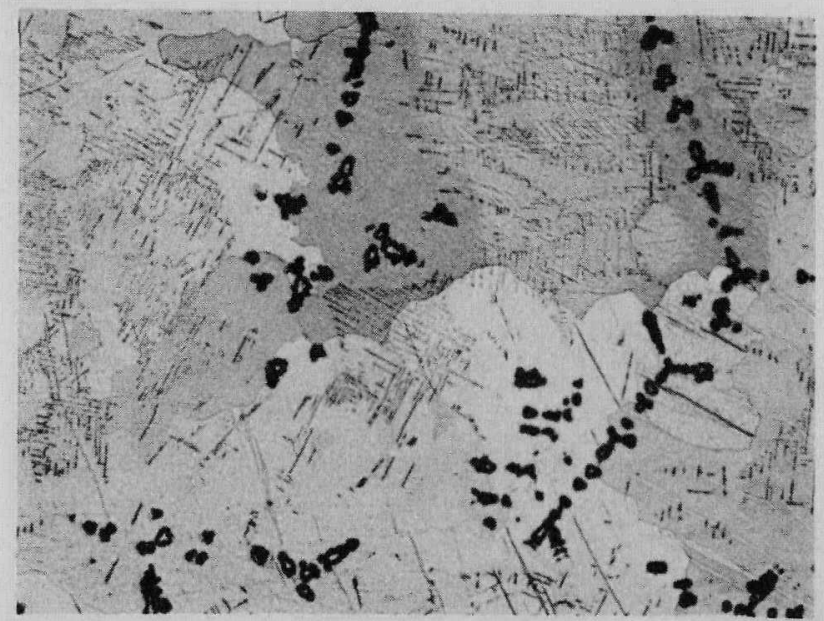

Micro 7856

Etched

$100 \mathrm{x}$

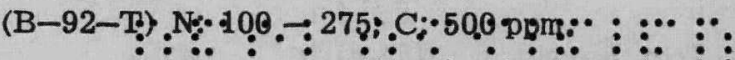

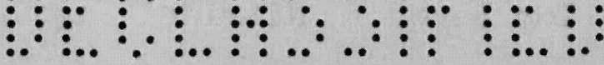


Figures 80 to 87. Precipitate in Nitrided and Liquated Ingots (Table X)

Figure 80

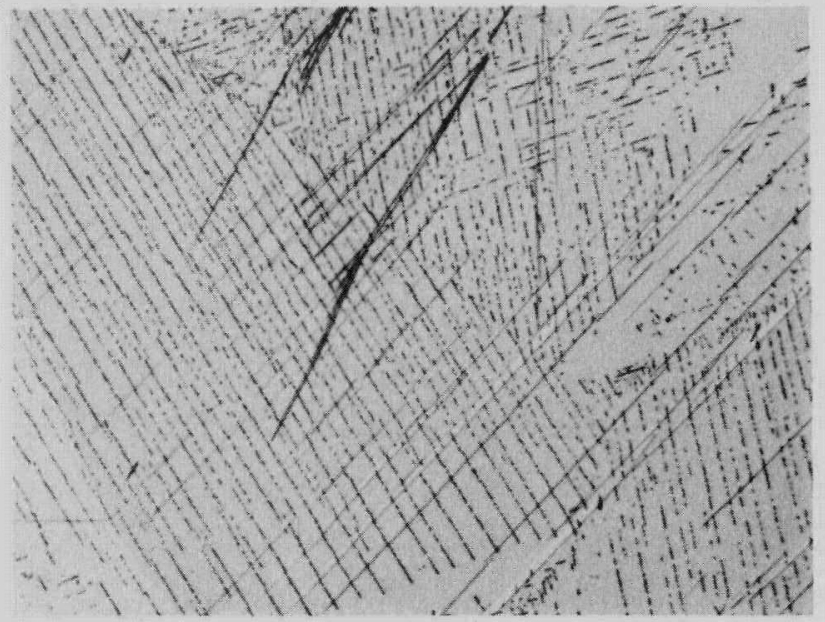

Micro 7395

Etched

$100 \mathrm{x}$

(B-65-B) Widmanstätten Pattern in Ingot with $32 \mathrm{ppm} \mathrm{C}$ and $50 \mathrm{ppm} \mathrm{N}$.

Figure 82

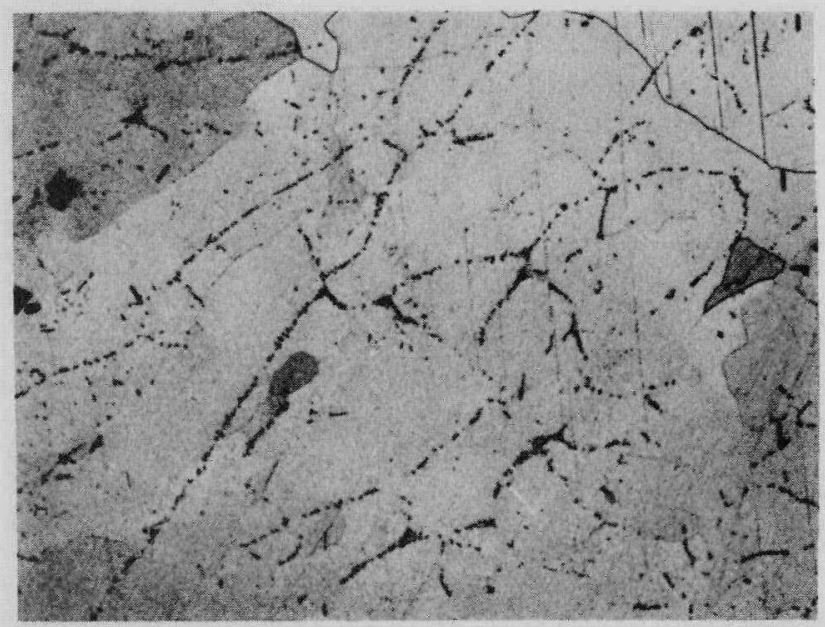

Micro 7471

Etched

$100 \mathrm{x}$

(B-75-B) Precipitate in Bottom of Ingot with $40 \mathrm{ppm} \mathrm{C}$ and $120 \mathrm{ppm} \mathrm{N}$.

Figure 84

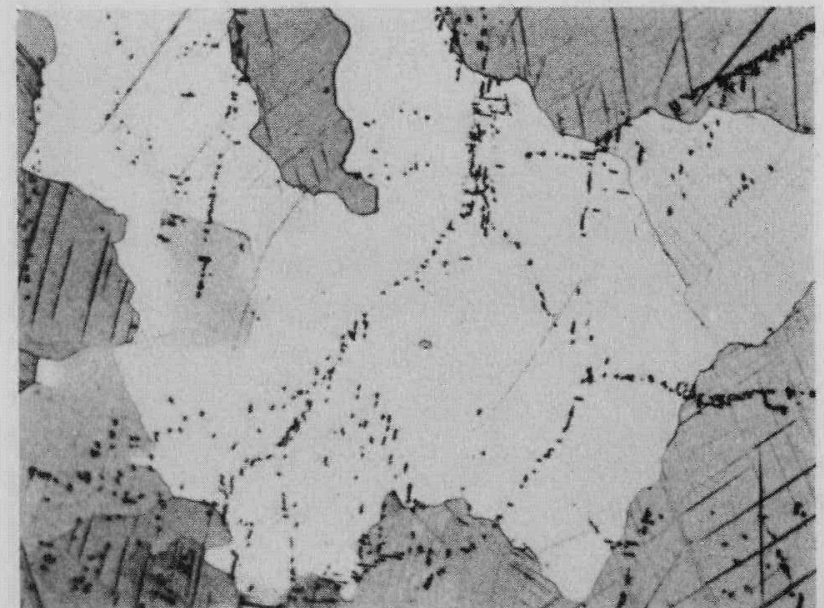

\section{Micro 7518}

Etched

$100 \mathrm{x}$
Figure 81

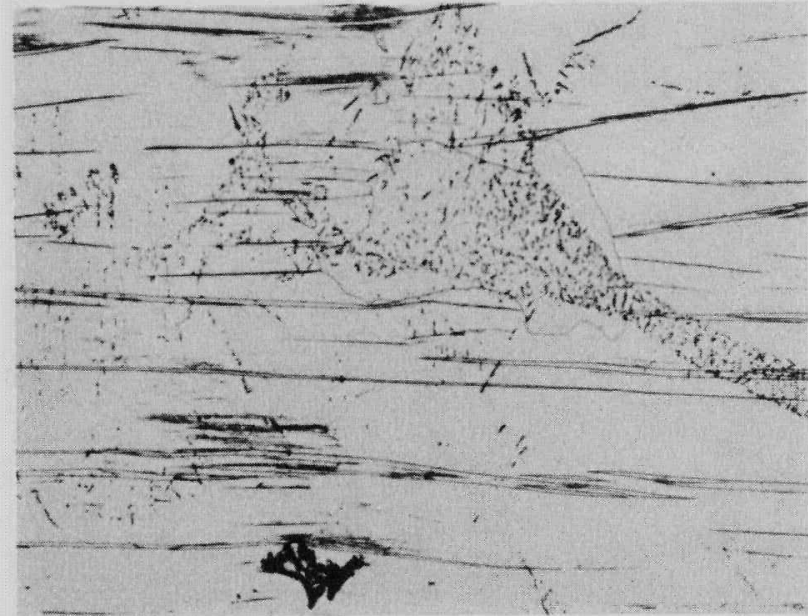

Micro $7394 \quad$ Etched $100 \mathrm{X}$ (B-65-B) Same Ingot as Figure 74. Other Area with Network Precipitate.

Figure 83

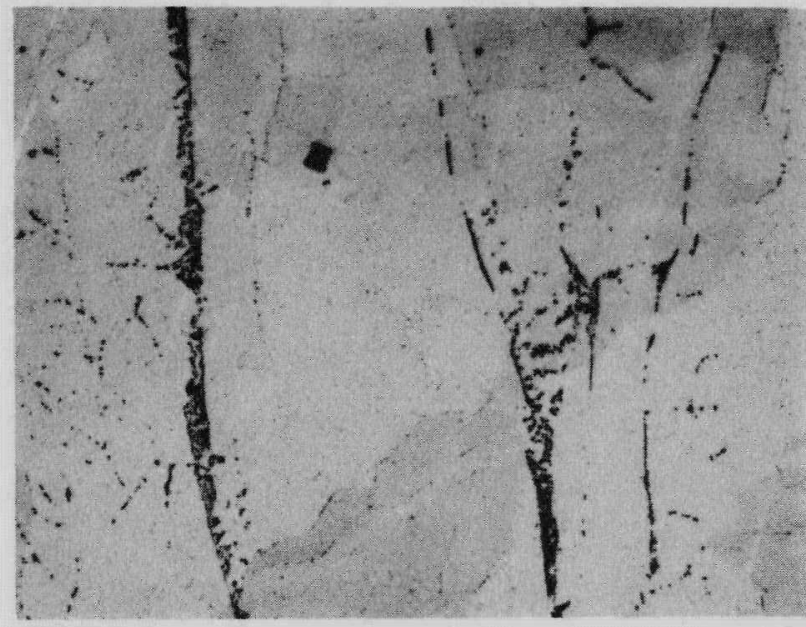

Micro $7472 \quad$ Etched $100 \mathrm{X}$

(B-75-T) Same Ingot as F'igure 74. Precipitate in

Top Area

Figure 85

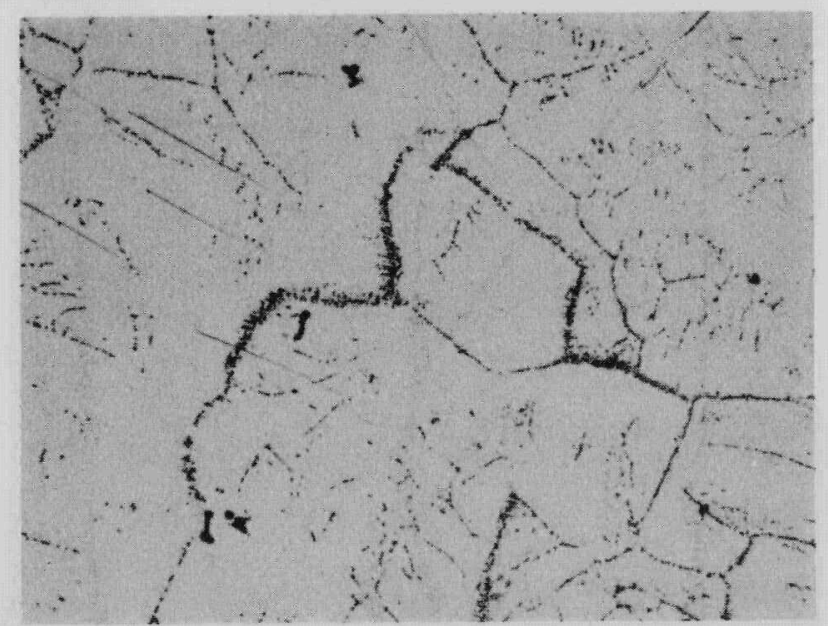

Micro $7519 \quad$ Etched $100 \mathrm{X}$

(B-78-T) More Precipitate in Top of Same Ingot

(B-78-B) Widmanstätten Pattern in Network form in. Bottom of Ingot with $15 \mathrm{ppm} C$ and $<$ ?to ppon 


\section{Figure 86}
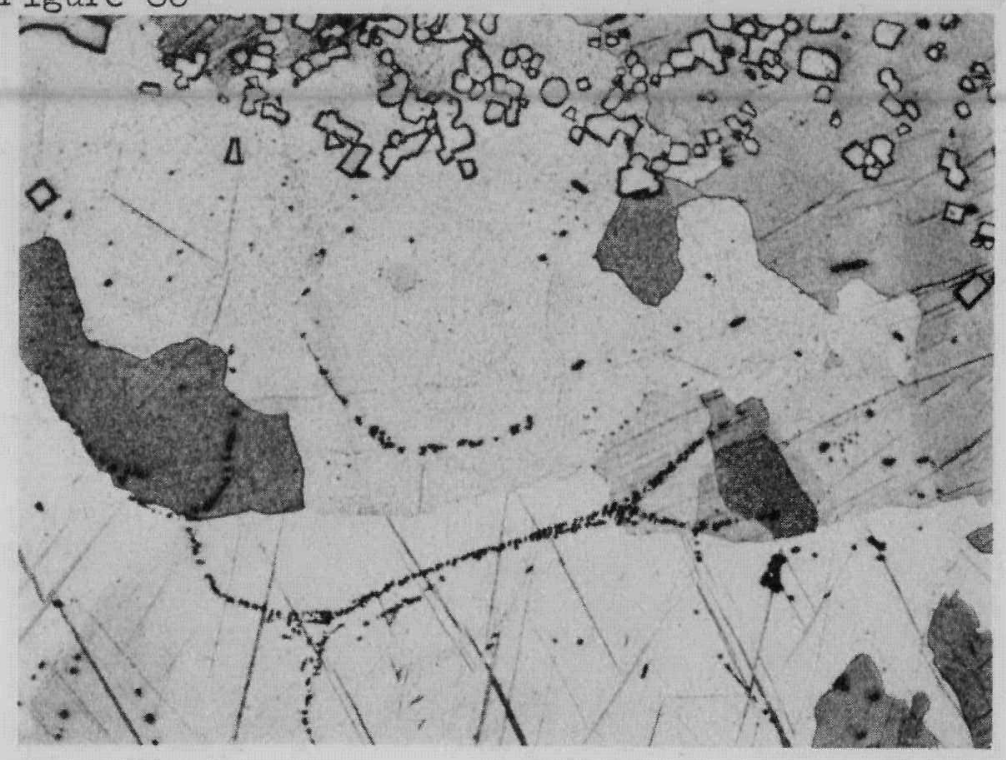

Micro 7556
Etched

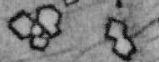

$\frac{2}{15}$

$100 x$
93

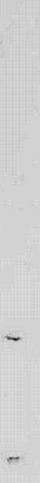

r

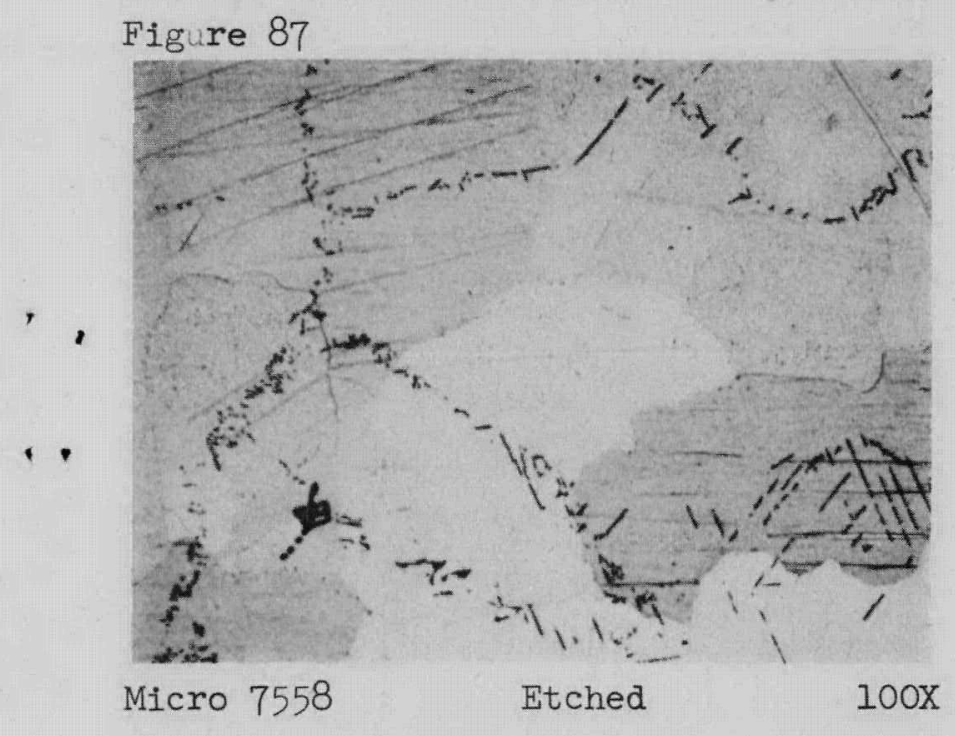

Figure 88

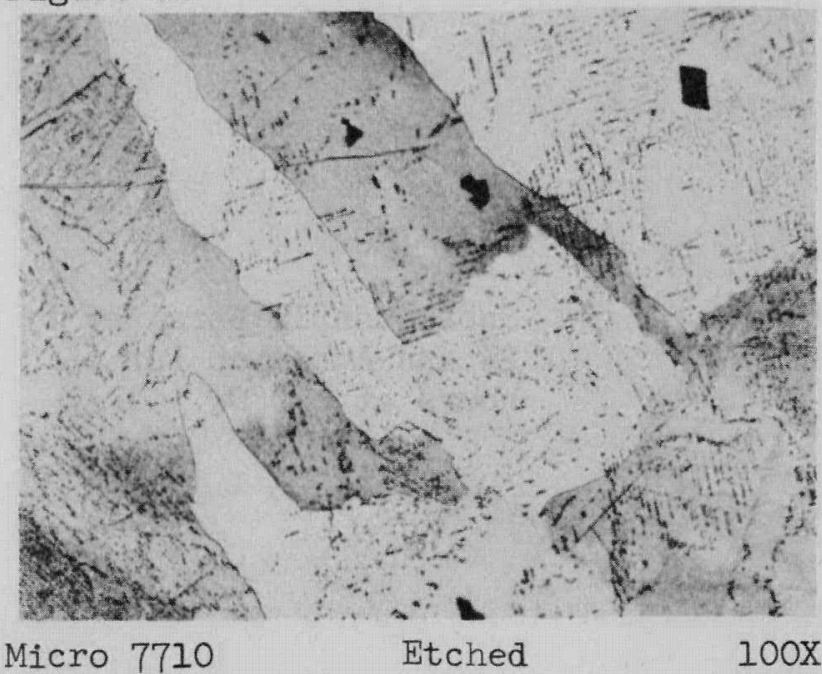

(B-81-B) One Step Nitrided and Liquated Metal with $225 \mathrm{ppm} \mathrm{C}$ and $25 \mathrm{ppm} \mathrm{N}$.

(Table XI)
Figures 86 and 87 . Ingot and liquated.

C: $12 \mathrm{ppm} ; \mathrm{N}:<10 \mathrm{ppm}$.

(B-80-T)

Top Layer in Top Section.

(B-80-B)

Few Inclusions. Widmanstatten Precipitate in Bottom Section.
Figure 89

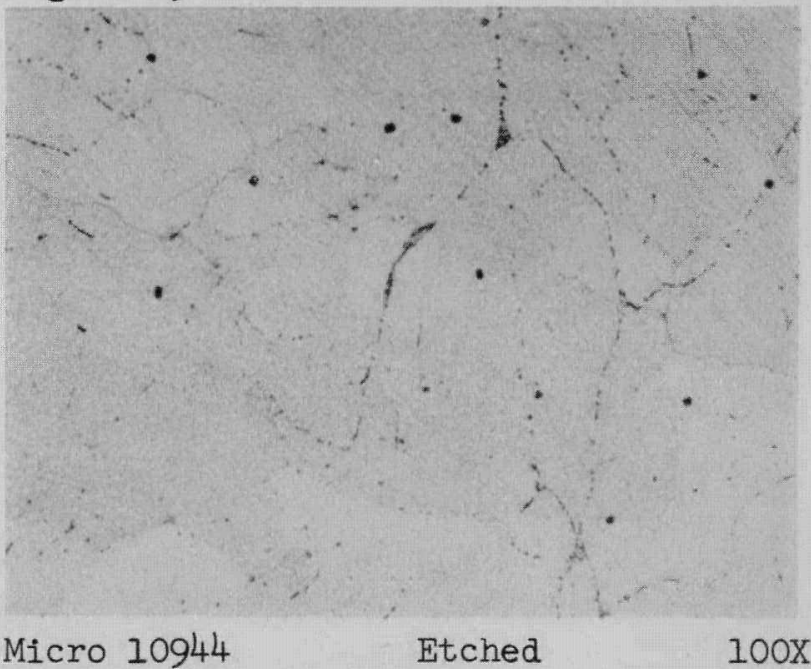

(B-166) Nitrided and Liquated With Calcium Addition. C: $45 \mathrm{ppm}$; $\mathrm{N}: 15 \mathrm{ppm}$. 
Figures 90 to 92. Effect of Tantalum Addition on Hanford Metal (Tablo XIII).

Figure 90

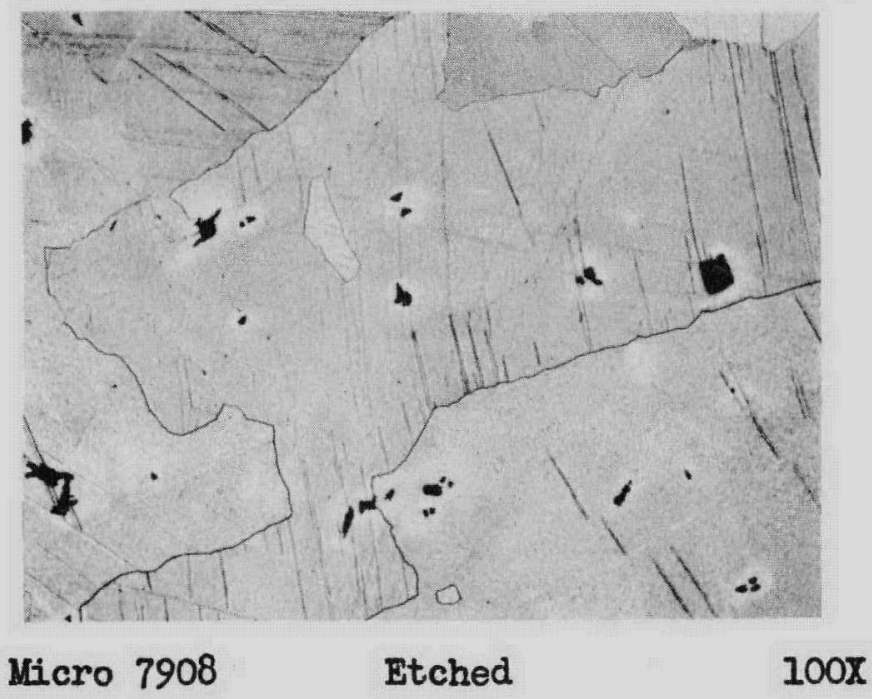

Figure 91

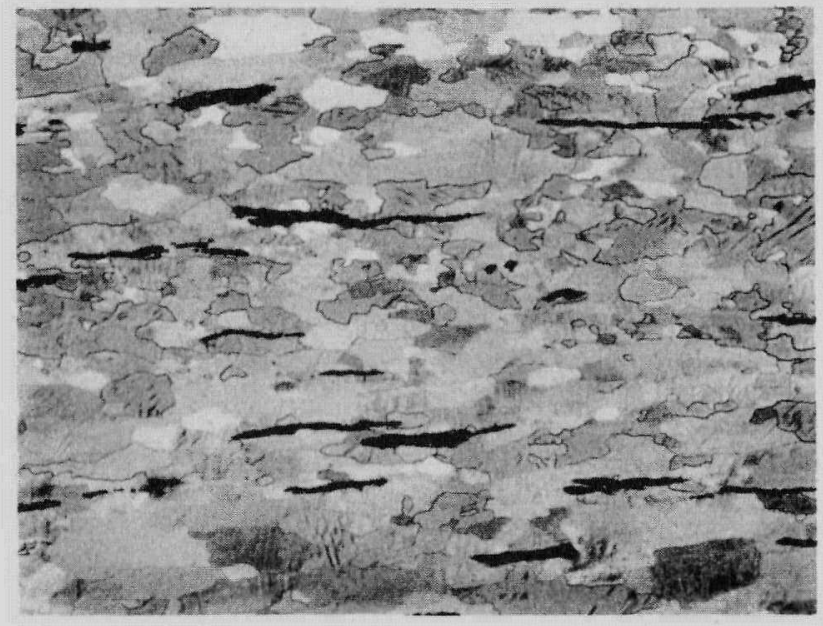

Micro 8016

Etched

$100 x$

Figure 92

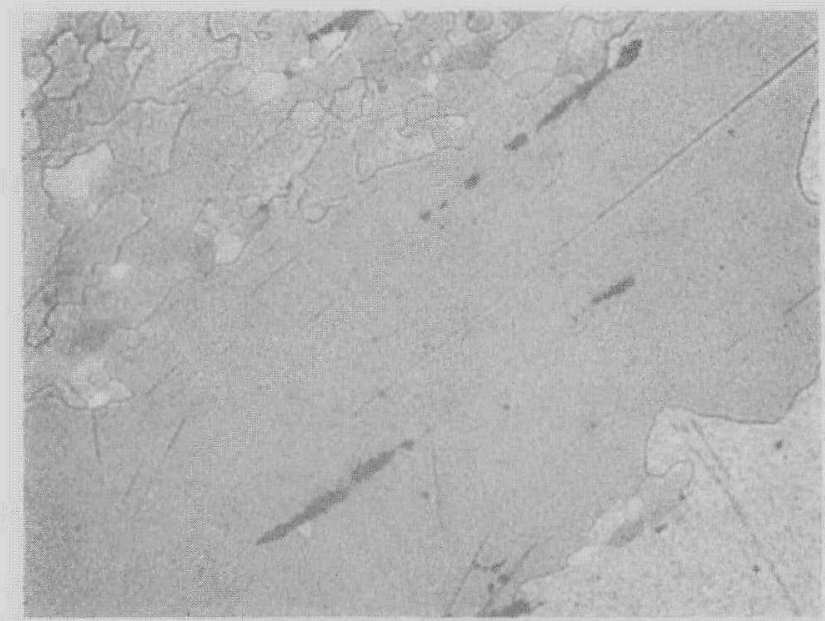

Micro 10234

\section{Ingot B-99}

Bottom Section with 200 ppm Tantalum.

As Furnace Cooled.
Reduced $80 \%$ by swaging at $300^{\circ} \mathrm{C}$.

Annealed for 2 hours at $575^{\circ} \mathrm{C}$.
Subsequently Strained by 2\% and Annealed for 65 hours at $640^{\circ} \mathrm{C}$. 
Figures 93 to 95. Biscuit Metal with Increasing Amounts of Tantalum (Table XIV).

Figure 93

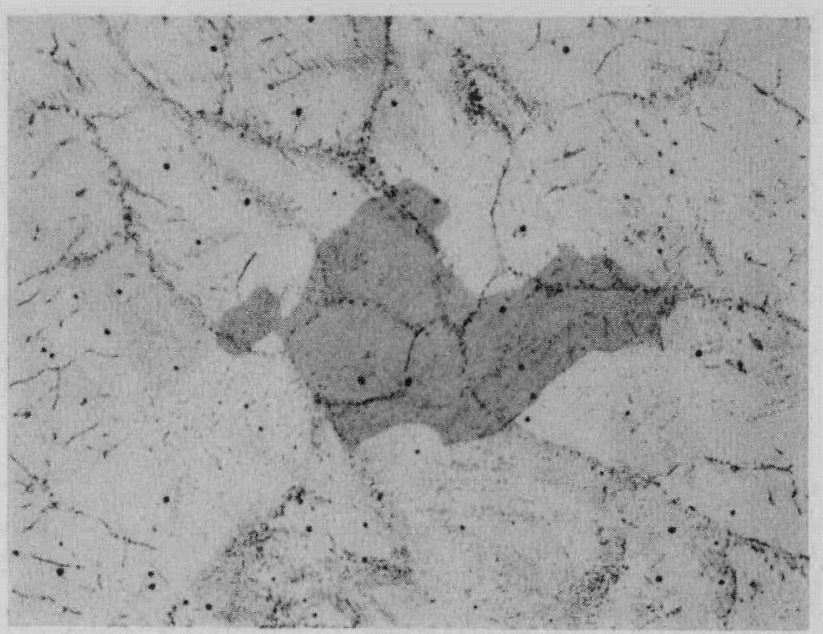

Micro 10299

Etched

$100 x$

Figure 94

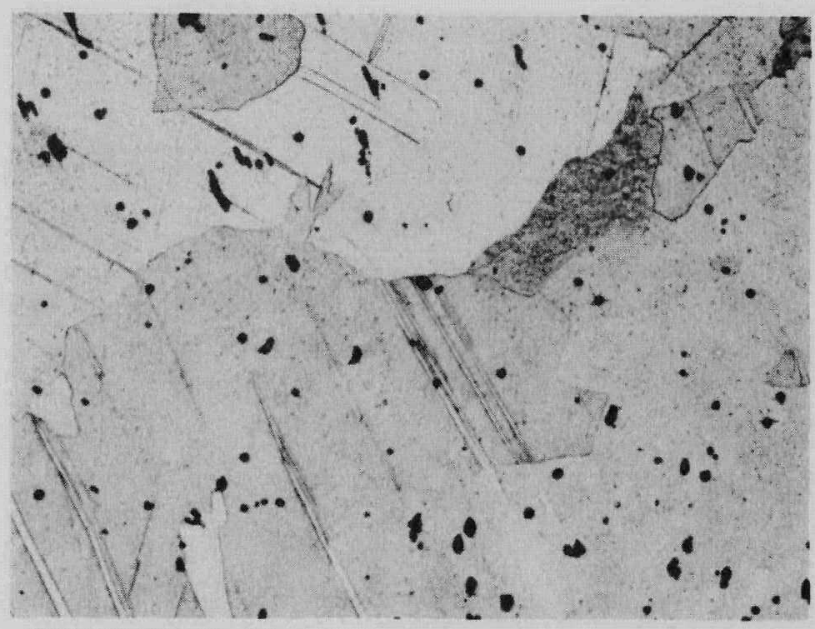

Micro 10249 Etched

$100 x$

Figure 95

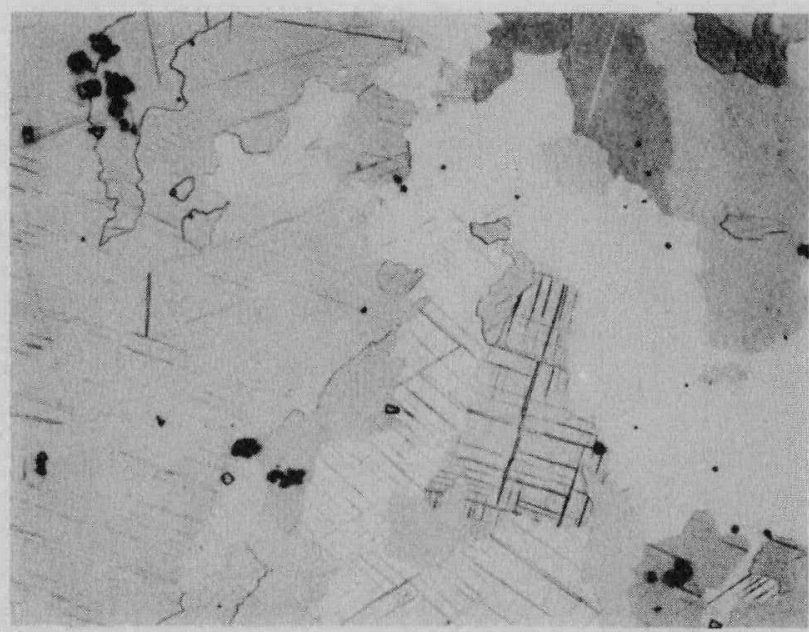

Micro 10258

Etched

$100 x$
Stirred with Tantalum Rod for I Minute. 100 ppm Tantalum.

Stirred for 3 Minutes. 160 ppm Tantalum.
Stirred for 9 Minutes. 3000 ppm Tantalum. 


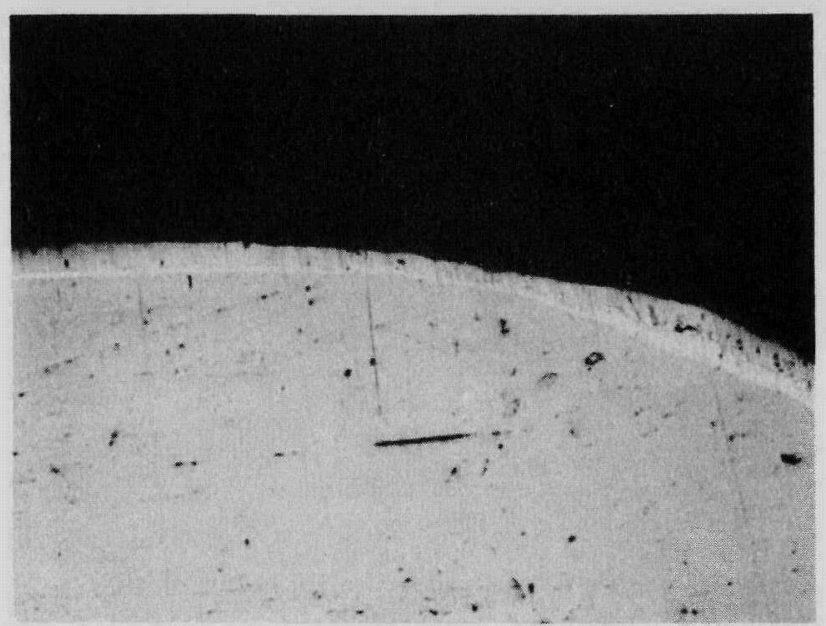

Surface Layer

Tantalum

Micro 10919

Polished

$100 \mathrm{x}$

(B-164) Reaction Layer Formed on Surface of Tantalum Stirring Rod.

Figures 97 to 98 . Uranium with Titanium and Zirconium Additions (Table XIII).

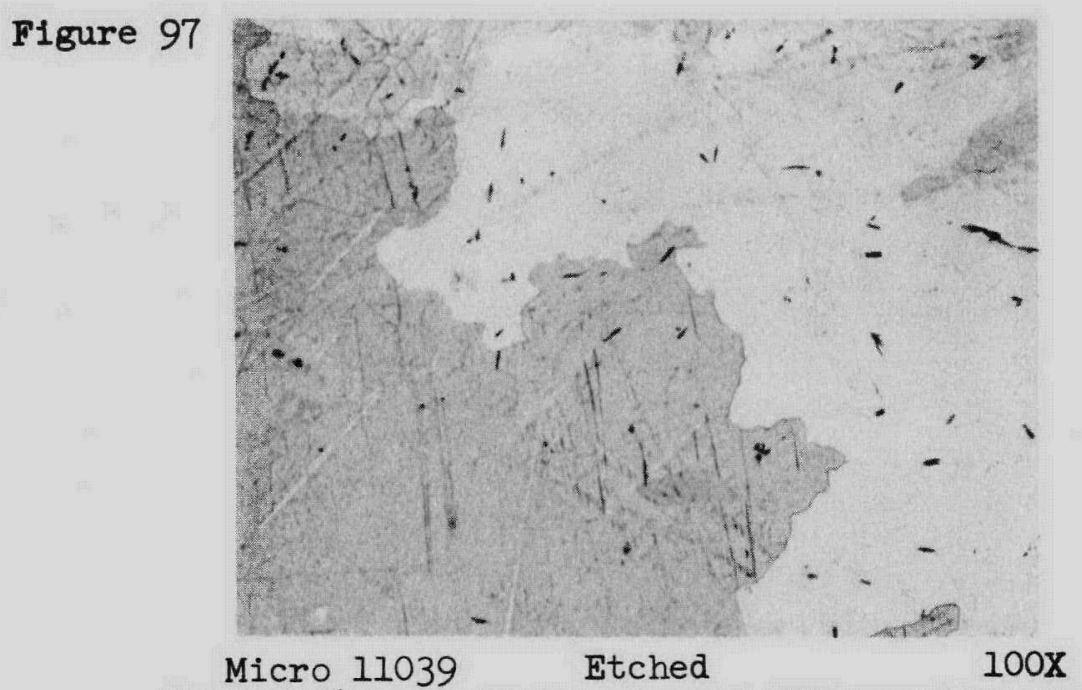

(B-120-T) Biscuit Metal with 750 ppm Titanium.

Figure 98

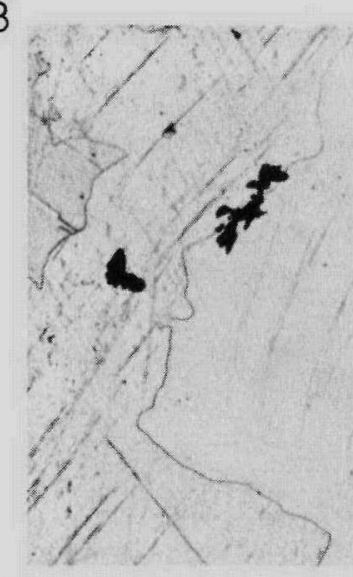

Micro 11037

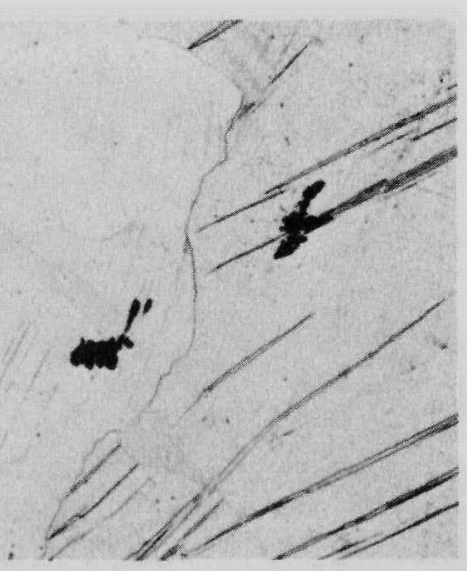

Etched

100X

(B-103-T) Hanford Metal with 100-175 ppm Zirconium. 
Figures 99 to 102. Effect of Solution Heat Treatment on the Structure of Hanford Slugs.

Figure 99

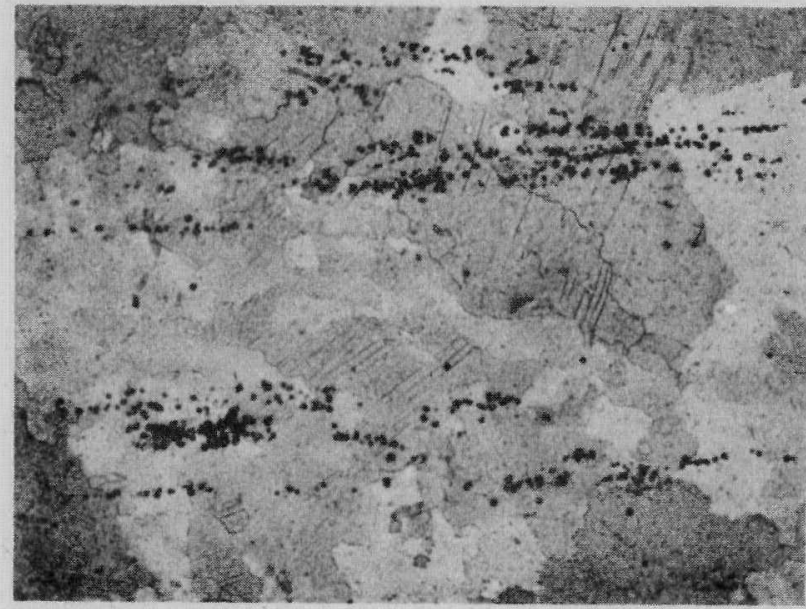

Micro 13727

Etched

(B-355-1100) Hanford Slug Annealed for 3 Hours at $1100^{\circ} \mathrm{C}$ and Water Quenched. Precipitate in Solution.

-

Figure 101

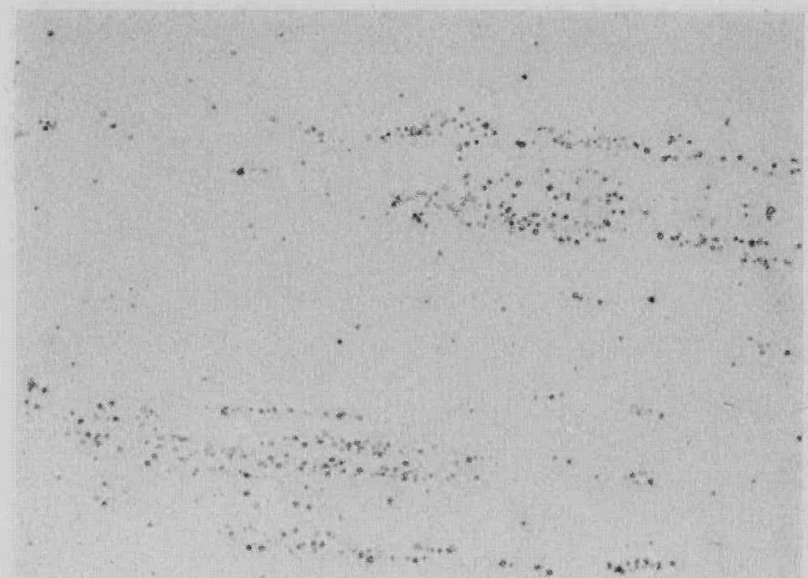

- Micro 13729 Hand Polished (B-355-1100) Same as Figure 99. Inclusions Rounded off.
Figure 100

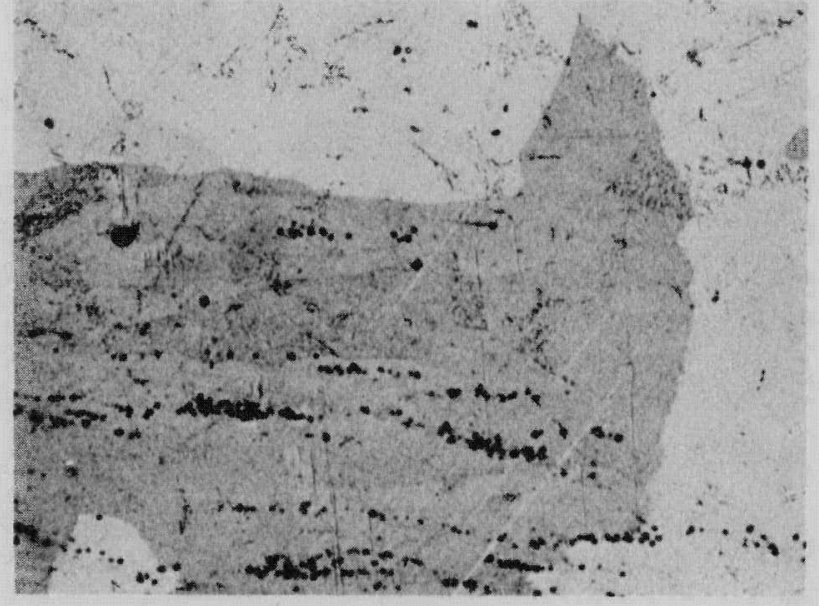

Micro 13732 Etched 100X (B-355-950-SC) Hanford Slug Annealed for 3 Hours at $950^{\circ} \mathrm{C}$ and Water Quenched. Reheated to $950^{\circ} \mathrm{C}$ and Furnace Cooled. Precipitate Reproduced.

Figure 102

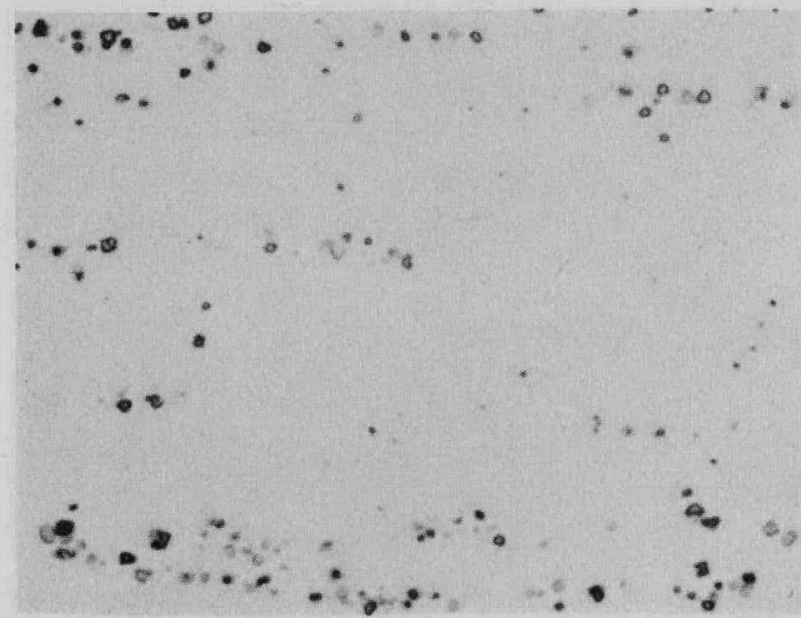

Micro 13731 Hand Polished $300 x$ Same as Figure 101 at Higher Magnification. 
Figure 103

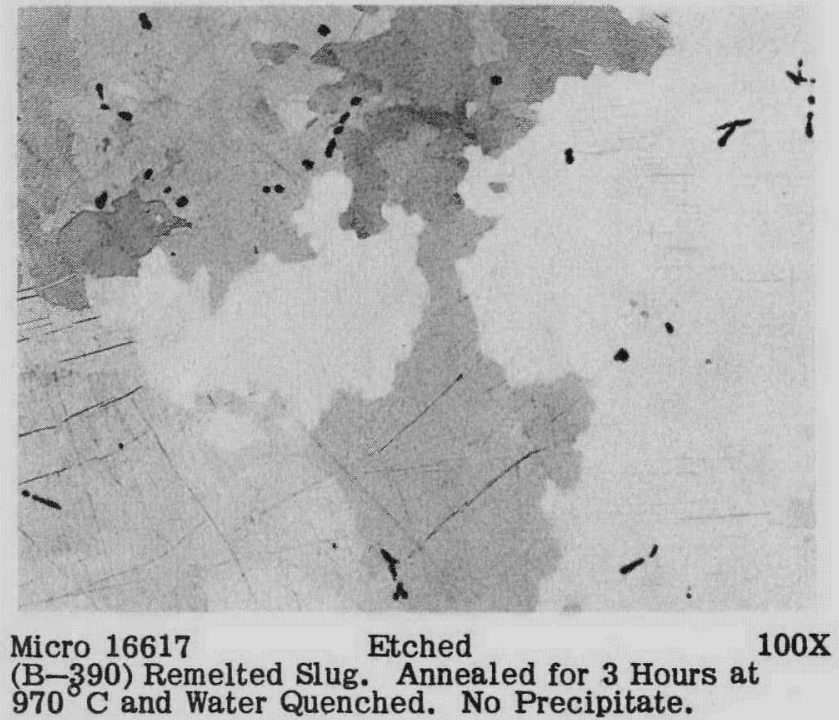

Figure 105

Micro $13977 \quad$ Hand Polished

Inclusions in end of $600^{\circ} \mathrm{C}$ Rolled Rod.

Figure 107

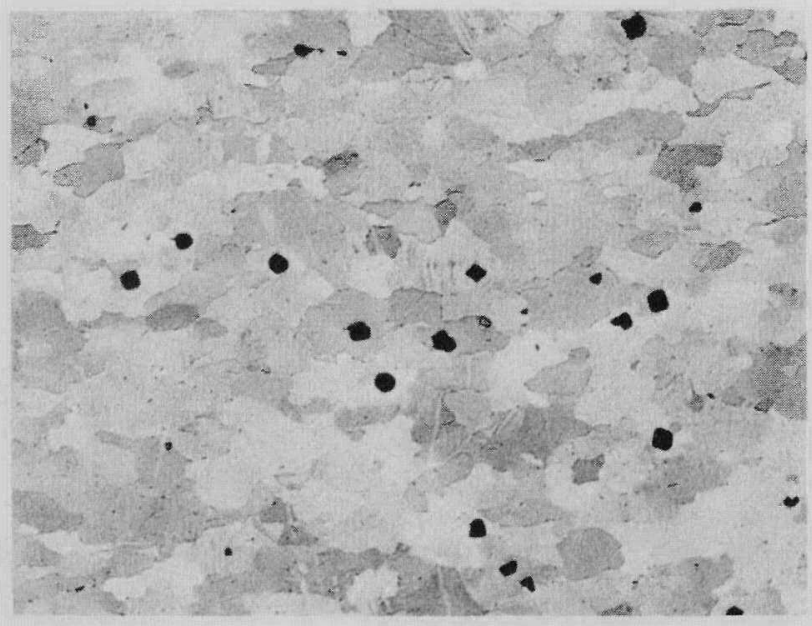

Figure 104

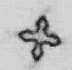

Micro 13975 Hand Polished

$100 \mathrm{x}$
Figure 106

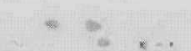

Micro 16618 Hand Polished 100X Inclusions in Center of $600^{\circ} \mathrm{C}$ Rolled Rod.

Figure 108

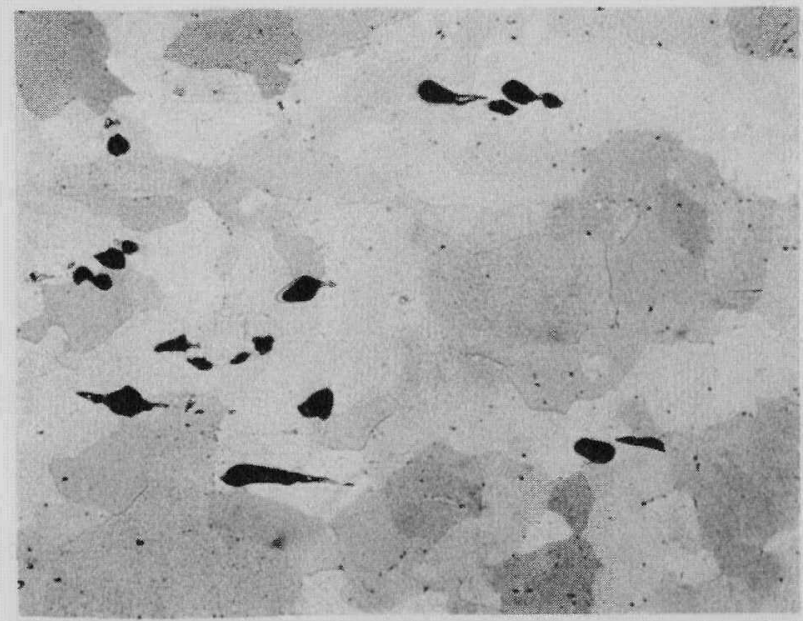

Micro 16619 Etched

$250 \mathrm{X}$

No Striations in End of $600^{\circ} \mathrm{C}$ Rolled.Rod,

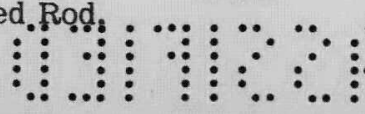

Few Striations and Fine Partic 
Figures 109 to 111. Reactor Grade Uranium (Fernald Slug Reject) Remelted, Heat Treated and $600^{\circ} \mathrm{C}$ Rolled.

Figure 109

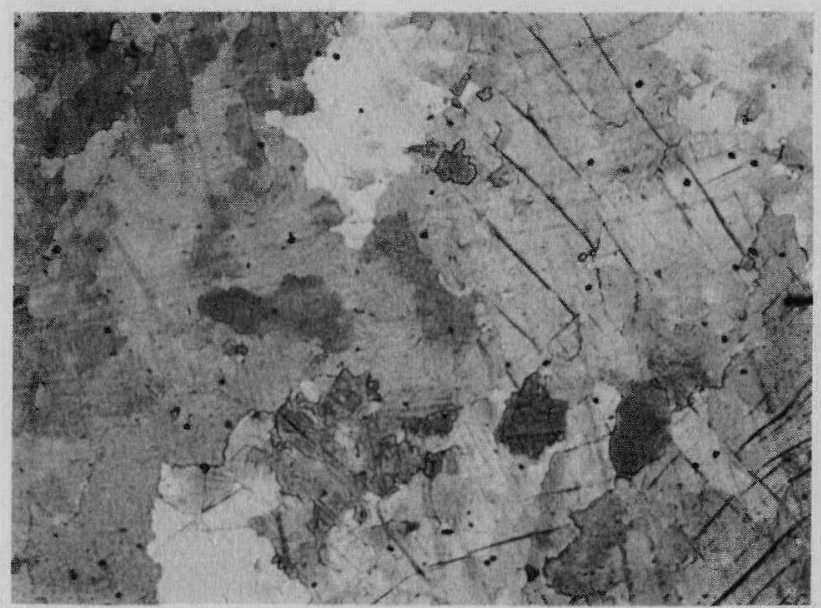

Micro 14280

Etched

$100 \mathrm{x}$

(B-405) Remelted Uranium, Annealed for 3 Hours at $970^{\circ} \mathrm{C}$ and Water Quenched.

Figure 110

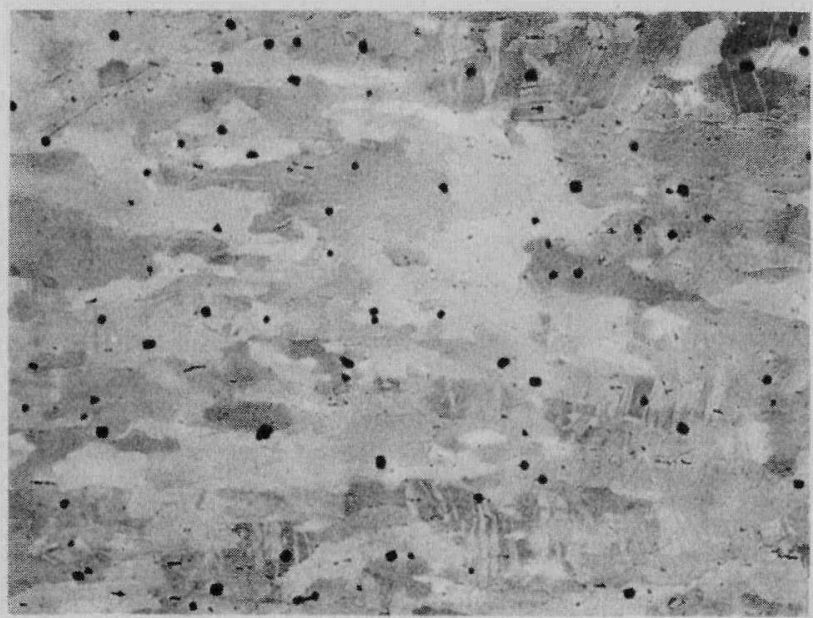

Micro 16621

Etched

$100 x$

No Striations in End of $600^{\circ} \mathrm{C}$ Rolled Rod.
Figure 111

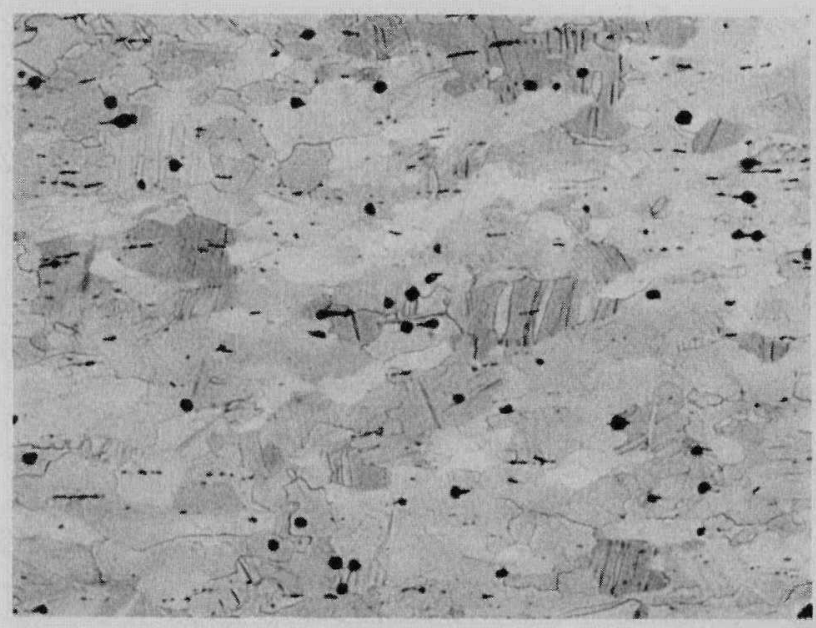

Micro 14335

Etched

$100 x$

No Striations in Center of $600^{\circ} \mathrm{C}$ Rolled Rod. 